\title{
A nálisis de tres espacios urbanos giennenses: la fuente, el palacio, el convento
}

\author{
A nalising three spaces in the city of Jaén: the fountain, the palace, \\ the convent
}

\author{
Luis Berges Roldán * \\ María Eloísa Ramírez de Juan **
}

\begin{abstract}
The Magdalena neighbourhood is the northern boundary of the city of Jaén, and overlooks the city. Among the most popular existing monuments of this neighbourhood we have chosen the most emblematical ones: in first instance, the former fountain of la Magdalena, which water supply came from the city stream -written evidence dating from I AD has been found. Then, the facilities of the former convent of Santo Domingo ( $X V \mid A D)$, and the palace of the Uribe family (XVII-XVIII AD). The data available for the present research has been obtained through the stages of cleaning, data collection, surveying and architectural restoration of the buildings and monuments. Also, a considerable amount of information has been extracted from documents kept in archives. There is information about the different individuals belonging to the Uribe family that could have been linked to the palace. $0 \mathrm{n}$ the other hand, information about the convent of Santo D omingo, and most specifically, information about its final stage as a male hospice. It was integrated within the Beneficiencia Provicincial [county charity] run by the Diputación Provincial [similar to a county council] of Jaén. They are three monuments that were linked among them for a long time by the most necessary of nature elements that enables life and city development: water. This research work is a contribution to the work carried out, through Archaeology and $\mathrm{H}$ istory, by different teams depending on the University of Jaén. These teams work on the research theme of the initial town planning that shaped the city in its early stages.
\end{abstract}

Keywords: Jaén, torrent, U ribe, hospice

\footnotetext{
* Dr. A rquitecto.

** Licenciada en Humanidades.
} 


\section{INTRODUCCIÓN ${ }^{1}$}

A hora, cuando el análisis de la ciudad de Jaén se está llevando a cabo desde su U niversidad a través de arqueólogos e historiadores, y poco a poco se va poniendo orden en los que fueron los principios valedores en la planificación, desde unos iniciales asentamientos humanos, hasta la constitución del hecho urbano de una ciudad fronteriza, puede resultar oportuno dar cuenta de cuanta intervención, desde otros campos profesionales se haya llevado a cabo, y que puedan ampliar el conocimiento de lo que se pretende con esta labor de investigación académica. La falta de la necesaria y rigurosa documentación, por una u otra causa desgraciadamente desaparecida, dio lugar a relatos y leyendas alejados del rigor histórico que precisa de la aportación de datos que enriquezcan la veracidad de un pasado.

A lo largo de años de ejercicio profesional como arquitecto, la intervención en edificaciones del casco antiguo ha dado lugar a la acumulación de datos que, en la actualidad, pueden ser tenidos en cuenta a la hora de enjuiciar, no solamente la actuación sobre ellos, sino también la puesta en valor en su propio contexto histórico.

Por otro lado, hoy se puede formular un nuevo análisis de lo que antes pareciese inconexo y carente de continuidad en sí mismo, de tal manera que el nuevo relato sea capaz de enlazar diferentes materias. Con este propósito hemos acometido el presente trabajo, que contiene algunos datos sobre, en este caso, tres elementos arquitectónicos bien conocidos e importantes como para organizar este relato. Estos tres elementos elegidos fueron, la fuente de La Magdalena, la casa-palacio de los U ribe, y el edificio del antiguo Convento de Santo Domingo (Fig. 1).

\section{LA FUENTE DE LA MAGDALENA}

La existencia de un manantial de aguas de gran pureza y abundante caudal aflorando al pie de un potente cerro calizo, elegido éste para construir sobre él las primeras arquitecturas militares defensivas de la futura ciudad de Jaén, va a permitir el asentamiento de pobladores y el correspondiente desarrollo urbano, tanto de la ciudad romana, como de la árabe, que se extendieron por la vertiente noroeste del cerro. Conocido como fuente de la Magdalena, abastecería de agua potable a toda clase de edificaciones, fuentes, baños y tenerías, y a numerosas industrias artesanales. Cuando su caudal disminuía por el estiaje, se recurría a las aguas del subsuelo a escasa profundidad, que se hacía aflorar a través de pozos domésticos.Y todas las aguas so brantes, se juntaban y corrían a cielo abierto en arroyos obedientes a la gravedad, para dar lugar a feraces huertas en las tierras llanas de extramuros. Mas tarde, con el desarrollo de la ciudad hacia cotas más bajas, otras fuentes como la de Santa María, vinieron a proveerla de agua potable. Jaén, famosa desde las crónicas medievales que la cantaban por la bondad y abundancia de sus aguas, con su crecimiento en el tiempo, fue perdiendo agua y fama (Lam 1).

La fuente de la Magdalena de la que Argote de Molina decía que "con la que entraba en el patio de aquella iglesia molían dos ruedas de molino, habiéndose sacado antes muchas más para diferentes fuentes públicas y particulares", y Ximénez Patón (1983:17) hablaba de que "hay en casas particulares más de mil fuentes llevadas por cauchiles" 2 . Más tarde el Deán Martínez de Mazas, a parte de considerar que Paton "pudo engañarse en el número" de fuentes, se que quejaba de que "en el día no vemos esta abundancia, aunque es verosímil

\footnotetext{
1 En relación al méto do utilizado hemos de señalar que, por tratarse de una recogida de datos de primera mano, realizada en general hace varias décadas, hemos considerado el relato personal de hechos como la manera más veraz de expresarlos, cosa que habría sido más fácil expuesta por terceras personas, como podrá hacerse posteriormente cuando este trabajo que ahora presentamos pueda formar parte de otro más amplio o generalizado, donde la frescura de la primicia pueda obviarse fácilmente.
}

2 Aunque parece una exageración, debe referirse a las tomas de agua. 
que se pierdan grandes porciones trasminadas ocultamente, sin que se repare en ello" (Martínez de Mazas 1978:42-43).

Situada la ciudad en una región montañosa de mermada pluviometría, donde las borrascas de uno y otro lado la alcanzaban ya exhaustas de agua, pero aún cargadas de viento, su vida diaria pendía principalmente de aquella fuente de La Magdalena y de sus ingeniosos repartidores de agua; y de pozos que lentamente se fueron contaminando con la filtración hasta ellos de aguas fecales escapadas de incipiente redes de evacuación ${ }^{3}$.

Los problemas que en los veranos se le presentaba al ingeniero al frente del servicio de aguas, de sus propuestas y búsqueda de soluciones, del aprovechamiento de antiguos depósitos acumuladores municipales ya olvidados, uno construido en el solar de lo que fuera el convento de la Coronada y el otro en la explanada junto a la calle Millán de Priego ${ }^{4}$. En una de aquellas búsquedas se pusieron los ojos en la antigua fuente de la Magdalena, a la cual se envió la poco dotada brigada municipal de obras 5 .

Ciertamente que yo nunca había traspasado aquel arco, proyectado en 1848 por el maestro de obras don Manuel Padilla (CASUSO, 1998:40), que daba acceso a un espacio sin sentido, en aquel mes de mayo de 1969, un rincón convertido en vertedero de basura por los vecinos del barrio ${ }^{6}$. Al fondo de aquel hemiciclo se abría una pequeña puerta que daba paso a un recinto cubier to, a un estanque cegado de cieno hasta el mismo borde, bajo el cual debía estar la entrada, mejor o peor entubada, del agua. Era to do lo que restaba de aquel fabuloso manantial abastecedor de un par de barrios urbanos, con caudales medidos en cañones y plumas que entonces figuraban en cualquier escritura de propiedad urbana (D IEZ, 1999; Tabla I, A.C ., 267.). De todas maneras, emprendimos la tarea de extraer todos aquellos metros cúbicos de lodo, operación lenta que nos iba a ocupar varios días.

Durante el seguimiento de los trabajos de desescombro descubrimos los restos de lo que sería una estatua de mármol blanco ${ }^{7}$ (Lam. 2). Una vez comunicado el hallazgo a la alcaldía, se procedió a obtener el permiso correspondiente para poder intervenir con más celeridad en el total esclarecimiento del posible contenido que debía encerrar aquella balsa de fango compactado, donde el agua del antiguo manantial ya no manaba. $Y$ todo lo que allí yacía enterrado poco a poco lo fuimos extrayendo y contemplando a plena luz del día. De esta manera, fueron apareciendo dos estatuas de togados de ambos sexos, de las que hallamos sus cabezas y alguna mano, así como

3 Aún recuerdo de niño, la traída de agua desde la fuente de Ríofrío de los Villares, fría, limpia sin añadirle nada.Tan fría que, el llenado con ella de la primera piscina municipal construida en el año 1940 en el solar que fuera del demolido convento de San A gustín que alcanzó antes a ser cuartel militar, llenado digo que se efectuaba en domingo e impedía meterse los lunes en sus transparentes y heladas aguas. Más tarde, las captaciones de Mingo y el depósito de Santa Isabel.Y el pantano de Q uiebrajano, insuficiente en nuestra pertinaz sequía y en el aumento del gasto, no siempre bien aprovechado y mucho menos controlado. Los cortes diarios, el llenado de bañeras y toda clase de receptáculos que luego se vaciaban alegremente cuando se oía llegar el agua a la red domiciliaria en un derroche absurdo carente de sentido, era de uso normal.

4 Donde luego se construyó un parque de incendios ya demolido

5 Durante mis años de arquitecto municipal.

6 Lamentable estado el de entonces que no tiene nada que envidiar al de hoy.

7 Desde el Ayuntamiento, subía cada mañana para ver la marcha de aquella tarea. Fue en una de aquellas visitas cuando me llamó la atención una masa pétrea totalmente enlodada que comenzaba a emerger, en la que pude apreciar algo que me resultaba conocido tras tantos años de dibujar la estatuaria clásica: un esculpido pliegue de manto. Recuerdo que pedí a un peón que vertiese un cubo de aqua sobre aquel sólido, lo cual, al quedar, lavado, se presentó ante mis ojos como parte perteneciente a una estatua de mármol blanco. Me parecía un milagro, a estas alturas del tiempo, poder contemplar el hallazgo de pieza de tanto valor en lugar tan degradado y olvidado. A finales del siglo XVIII el D eán Mazas escribía: “... quedaban pocos restos romanos fuera de las inscripciones y piedras ya citadas, y algunos pedazos de columnas de mármol blanco, morado y de otros colores que se han sacado de la fuente de la Magdalena con motivo de limpiarla, y de hacer alguna obra de bien... " MARTín EZ DE MAZAS, J "Retrato al natural... " p. 37. 
los respectivos pedestales sobre los cuales se habían erigido (Lams. 3-14), junto con un fragmento de placa funeraria, ambos recogidos por C. González y J. Mangas en su Corpus de Inscripciones Latinas de Andalucía ${ }^{8}$.

A partir de estas inscripciones podríamos deducir que se trataría de un monumento funerario al mandatario romano y esposa que canalizaron las aguas del manantial.

También encontramos capiteles y fustes corintios (Lams. 15-17) , y un buen número de pequeños objetos en bronce tales como fíbulas, una pequeña cabeza de toro, algunas cabezas forjadas de clavos y numerosos fragmentos pertenecientes a objetos de pasta vítrea.

$\mathrm{N}$ inguno de los elementos marmóreos se presentaba en posición vertical ni tampoco en un manifiesto orden de colocación, mostrando a las claras haber sido movidos o derribados violentamente tras un incendio, que había calcinado en parte tanto a capiteles como estatuas ${ }^{9}$.

A quellos trabajos se completaron con la colocación de una verja metálica que se diseñara para cerrar el enorme hueco bajo el arco hasta una determinada altura, verja que años después fue ampliada hasta cubrir todo el vano.

\section{LA CASA-PALACIO DE LOS URIBE}

Escribir sobre la denominada casa-palacio de los Uribe de Jaén es escribir con tristeza, como consecuencia de su reciente desaparición al ser demolida hasta los cimientos, a cuenta de levantar en su solar un edificio destinado a la enseñanza oficial, según pretensión de la correspondiente Delegación de Educación de la Junta de Andalucía, destino que hasta la fecha no se ha llevado a cabo. Tan incomprensible decisión nos privó de poder poseer en esta ciudad una de las pocas edificaciones domésticas de finales del s. XVII que milagrosamente aún conservábamos.

En esta casa el manantial de la Magdalena jugaba su papel a través de los siglos, agua que vamos a seguir utilizando como hilo líquido conductor en nuestro relato.

El llamado palacio de los U ribe no fue construido por miembros de tal apellido, sino por los de otro también ilustre en nuestra provincia como fuera el de la familia de los Messía. Ya en el año 1528 y en las proximidades del edificio objeto de nuestro estudio, concretamente en la plaza de Santo Domingo, vivió don Fernando Messía de la Cerda (CAÑ ADA, 2006), cuyo domicilio estaba abastecido por un cañón de agua del Raudal de la Magdalena, por decisión real ${ }^{10}$.

La que estudiamos, que fue una de las viviendas más representativas de nuestra ciudad, debió pasar a manos de la familia Uribe en el siglo XVIII, y su apellido dio incluso nuevo nombre a la antigua calle Santo D omingo Bajo, denominación con la que aparece en $1752^{11}$, ya que era frecuente denominar a la calle con el nombre de algún vecino ilustre. Situada su fachada principal en la Plaza de las Herrerías,

\footnotetext{
8 Traducción de las inscripciones halladas en la Fuente de la Magdalena:

Placa funeraria:"C onsagrados a los dioses Manes, Q uinto C assio, tuccitano, domiciliado aurgitano el lugar forma parte de la herencia”. (Gonzalez, Mangas 1991:69).

Pedestal: A Fabia Murilla, hija de Tito Julio Per(... ), su heredero lo puso en cumplimiento del testamento, con el visto bueno del decreto de los decuriones. (González, Mangas 1991:73)

9 MARTÍNEZ DE MAZAS, "Retrato al natural..." p. 37. A instancias propias todo aquel hallazgo en un solar o espacio urbano perteneciente al municipio fue donado al nuevo Museo Provincial, donación condicionada a que al Ayuntamiento se le entregase una reproducción de ambos togados, según consta en documento que yo mismo redacté, condición que hasta la fecha se ha incumplido y que no estaría demás tener en cuenta en los momentos actuales, en los que parece se trata de recuperar este espacio tan cargado de historia olvidada y que bien valdría la pena para valorar y testimoniar públicamente los siglos I y II de nuestra era.
}

10 DIÉZ BED MAR. “El Raudal de la Magdalena... ".Tabla I Actas Capitulares.

11 A.H.P.J, C.M.E. LEGAJO S 7781, 7782, 7792 
también llamada Plaza del Hospicio, hoy Luisa de Marillac, en la que le acompaña el Palacio de Villardompardo ${ }^{12}$ hasta no hace muchos años, cuando se acordó su derribo, destacaba entre la oscura maraña de casas en que se había convertido el barrio de La Magdalena, antigua collación del mismo nombre.

No quedan muchos ejemplos de esas llamadas casas "principales", que si bien no llegan a ser palacios, si muestran fachadas armoniosas, bien estructuradas, con puertas adinteladas confeccionadas con sillares bien labrados, fachada rematada en lo alto por una batería impar de arquillos, en algunos casos con torreón de esquina y vanos, defendido por austera rejería ${ }^{13}$.

El edificio, como ya hemos dicho, no siempre perteneció a los U ribe.Tenemos datos de mediados del siglo XVIII, que nos dan como propietario a D on Diego Manuel Messía, Señor de La Guardia ${ }^{14}$, del que D. Agustín U ribe fue administrador en el tercer cuarto del siglo X VIII, $y$ tal vez sea por este motivo por el que, hasta su demolición, figurase en la fachada su escudo de armas (Lam. 24). D on Rafael C añada (2006), nos dice que "uno de los cuarteles del escudo coincide con el de los Messía", lo que abunda en la idea de que la casa pertenecía a esta familia, como así lo atestigua la declaración que para el $C$ atastro del Marqués de la Ensenada, realiza su propietario en 1752 (CAZABÁN 1924:371).

\section{La familia Uribe. Antecedentes}

Para una aproximación al estudio de los U ribe y su relación con los Messía, tenemos dos fuentes, dos publicaciones monográficas. La primera de un miembro de la propia familia Uribe, concretamente de Don Agustín de Uribe-Salazar y Fábregas (2004) titulada LoS Uribe Salazar y su Historia, que nos presenta un estudio detallado del linaje familiar basado en la documentación conservada por la familia en su biblioteca particular; y la segunda del investigador local D on Rafael Cañada Q uesada (2006), que lleva por título Linajes Nobles en la ciudad de Jaén: Los Uribe, que nos proporciona una amplia y pormenorizada relación de los miembros de esta familia giennense, desde el siglo XIII hasta nuestros días. A demás, como fuente documental directa contamos con los datos del $C$ atastro del Marqués de la Ensenada, donde aparecen las declaraciones de bienes de numerosos miembros de las dos familias. A partir de ellas nos hemos planteado, también, mencionar a los personajes de este linaje más directamente relacionados con nuestra ciudad y concretamente con la collación de San A ndrés, a la que pertenecen los edificios objeto del presente estudio.

Para la primera mitad del siglo XVIII tenemos los nombres de algunos miembros de la familia Uribe en Jaén, aunque en principio no parecen estar relacionados con el edificio que nos ocupa.

Comenzando por el primer Uribe del que tenemos noticias en Jaén, que fuera alcalde perpetuo de la fortaleza de la Peña de Martos (CAÑ ADA 2006:350), el Caballero Veinticuatro de Jaén, Don Pedro de San Martín y Uribe, Capitán de Caballos y Gentilhombre de Cámara del Rey, fallecido en $1765^{15}$.

12 Palacio, en cuyas entrañas se guardan celosamente los Baños Á rabes, cuya mejor suerte se ha debido, sin duda, a la monumentalidad de su fábrica, ya que siempre ha primado lo espectacular a la hora de conservar y restaurar, y se ha menospreciado la arquitectura doméstica de mayor o menor importancia, y que bien pudo estar comunicado con los palacios musulmanes, que fueron donados a los dominicos para construir el convento de Santa Catalina Mártir

13 Si exceptuamos la llamada "Casa de los Priores" en la calle Hornos Mírez no 1, cuya restauración nos ha proporcionado un magnífico ejemplo de arquitectura civil en la Edad Moderna. Situada en el actual barrio de la Magdalena, esta vivienda se ha podido conservar gracias al esfuerzo personal y económico de su actual propietario, Don Alejandro Palacios Castro, quién amablemente nos invitó a visitarla y explicarnos su evolución arquitectónica.

14 Sobre el tratamiento del "Don”, Vid.: CATALÁ SANZ, J. A. Rentas y patrimonios de la nobleza Valenciana en el S. XVIII. Madrid, 1915.

15 A.H.P.J, C.M.E. Legajo 7794. 
Por lo que se refiere a la rama U ribe-Salazar, el primero del que encontramos mención es Don A gustín Mateo de Uribe-Salazar y Fernández de Castro, caballero del hábito de Santiago y también Caballero Veinticuatro de Jaén, Corregidor en Zafra (Badajoz), que murió en 1720 , por lo que no puede aparecer en las declaraciones del Catastro de Ensenada de nuestra ciudad, pero sí tenemos constancia de que vivió en Jaén, aunque no sabemos aún en que calle tenía fijada su residencia.

0 tro Uribe-Salazar, concretamente Don A gustín Eusebio U ribe-Salazar y Muñoz Ronquillo de Robres nacido en Z afra, se localiza en Jaén y tenemos constancia de su fallecimiento en dicha ciudad el 28 de Junio de 1786, en la collación de San Andrés ${ }^{16}$. Fue, como otros miembros de la familia, Caballero Veinticuatro de Jaén, Alférez Mayor y Capitán de Caballos, caballero de Montesa, señor de la casa de U ribe ${ }^{17}$. Tuvo además de cuatro hijos, una hija que emparentó con la familia Messía por el matrimonio de Doña Juana Dorotea, nacida el 12 de febrero de 1734, con Don Francisco de Paula Ramírez Rico de Rueda Poblaciones Godinez y Sandoval Messía.

\section{El Proceso de formación de la Casa-Palacio}

Tenemos las declaraciones en el $C$ atastro de Ensenada de los bienes de D on Diego Manuel Messía, Señor de La Guardia, y Marqués de A capulco, que declara como forastero varias propiedades en la manzana donde luego estará la Casa-Palacio de Los U ribe. Esta manzana estaba compuesta, además de por las citadas propiedades, por otras del convento de Sto. Domingo y por las de algún o algunos otros propietarios aún por investigar.
En la Calle Baja de Santo Domingo, hoy Uribe, Don Diego declara dos viviendas, una lindaba con la iglesia del Convento de Santo Domingo, y la tenía arrendada a D on A gustín de U ribe que era entonces, 1752, su administrador ${ }^{18}$. La otra era una vivienda principal (Láms. 24-28) con un alquiler estimado de 42 ducados, constando de portal (Lam. 26), cuatro salas y un cuarto y en alto cinco salas más, cuatro cuartos, y otros seis cuartos pequeños, una cocina, bodega y dos caballerizas, dos patios pozo, fuente, terrado, granero y unas dimensiones de veintiuna por veintitrés varas. Por arriba lindaba con casas pro pias y por abajo con otras de Don Francisco Carvajal, pertenecía a la collación de San Andrés.

En segundo lugar, en la llamada calle Maestra Baja, de la que en algún momento formó parte la calle de Santo Domingo Alto, calle que limita por arriba esta manzana, D on D iego declara otra casa, arrendada a Francisca de la Camara en 10 ducados, que tenía unas dimensiones de cuatro varas de ancho o fachada por siete de largo o fondo, y que constaba de portal y cocina en alto, algo habitual en nuestra ciudad durante la Edad Moderna, más un cuarto y corral. Lindaba por arriba con casa de Mariana de los Santos y por abajo con casa de Luis Cobo Castrillo. No sabemos, aún, si esta casa pertenecía a la manzana objeto de nuestro estudio.

0 tra propiedad, de la que no tenemos datos suficientes para asociarla a esta manzana, es una situada en la calle o plaza de la Herrería, que declara Ana Maria del Moral, que tiene un puesto de vino y aguardiente, pero que no aporta más datos, por lo que tendremos que esperar a consultar otras declaraciones para saber algo más sobre de este inmueble ${ }^{19}$.

16 CAÑ ADA Q UESADA, R. “Linajes N obles... "P. 352. En cuanto al patrimonio formado por bienes muebles, también tenemos noticia de unas casas en el Arrabalejo dejadas para ordenarse sacerdote su hermano Don Miguel, por su padre Don Eusebio de Uribe.

17 Q uién otorgó un primer testamento en Jaén ante Don Francisco Cobo Mogollón el 16 de junio de 1720. Don Francisco Cobo Mogollón, escribano que estuvo activo al menos hasta 1752, ya que con ese mismo nombre aparece en las declaraciones del catastro de Ensenada.

18 A.H.P.J., C.M.E. LEGAJO, 7792.

19 A.H.P.J., C.M.E. LEGAJO, 7792. 
Las casas de las que gozaba D on Francisco de Carvajal y Mendoza, caballero veinticuatro de Jaén, corregidor y justicia mayor de Córdoba, constituían un Mayorazgo que fundara Doña Catalina de $\mathrm{N}$ avarra. D on $\mathrm{N}$ icolás de U ribe Salazar ${ }^{20}$, Capitán del Regimiento de Caballería de la costa, otorgó testamento en Antequera el 9 de enero de 1755, por el cual agregó varios bienes a dicho mayorazgo, entre ellos "unas casas suyas propias en la calle de Santo Domingo Bajo donde él habitaba, que poseía otras accesorias y que lindan con el Convento de Santa Catalina Mártir de la orden de Predicadores de Santo Domingo".

Don A gustín de U ribe, el administrador de D. D iego Messia, en la declaración del Catastro de Ensenada, en 1752, dice que posee dos casas en el Arrabalejo ${ }^{21}$, pero no declara ninguna propiedad en la Calle Santo Domingo Bajo ni en la Plaza de las Herrerías o del Hospicio.

Con respecto a la biografía de este personaje, cabe señalar que su nombre completo era A gustín Ignacio U ribe-Salazar y Buenache, nacido en Villanueva de los Infantes, Ciudad Real, en el año 1728. Al enviudar, el 24 de abril de 1762 de Doña Maria Leonor de Porcuna Linares Godoy, padres de Don A gustín Tiburcio, retornó a su padre los bienes que había recibido como dote para su boda.

En una fecha indeterminada entre las declaraciones del Catastro de Ensenada y 1778 debió adquirir las propiedades de Don Diego Messía 22, ya que en "1778 se le adjudica por procedimiento de subasta pública ${ }^{23}$, el solar anexo a su casa de la calle de su nombre por la cantidad 1.644 reales, el que hacía esquina con ella y con la plaza de las Herrerías, más tarde del Hospicio", formalizando la escritura ante Rafael Antonio de Luna el 7 de Febrero de 1778. Después adquirió de Don Juan Manuel de Robles y A cuña las casas que lindaban por las espaldas con dicho inmueble, edificación de la calle Santo Domingo, junto al convento, que había sido de la fundación creada por doña Florentina de Robles y por D oña C atalinaValladares y C oello de Portugal por escritura ante Don Antonio José de la Barrera, en 1789. También adquirió para aumento de dicha casa, otras pequeñas lindantes con ella y con la iglesia del Convento dominico de Santa Catalina, por escritura ante Don A ntonio José Barrera el 17 de diciembre de $1794{ }^{24}$, formando de esta manera una extensa propiedad urbana, las que serán Casas Principales de la familia durante el siglo siguiente.

Tenemos conocimiento de una serie de miembros de la familia Uribe, que están relacionados de un modo u otro con la collación de San Andrés aunque no podemos asegurar en qué casas tendrían fijada su residencia, pero este dato si los liga a una determinada zona de la ciudad, ya que son bautizados o celebran sus funerales en la Iglesia de San Andrés, ocupan cargo en la Santa Capilla, o son educados en conventos de la zona ${ }^{25}$.

20 CAÑ ADA Q UESADA, R. “Linajes N obles... ” p. 364.

21 A.H.P.., C.M.E. Legajo 7781. D otación para ingresar en el convento de Santo Domingo de Don Miguel (o Manuel) de Uribe, clérigo de Menores.

22 Ya hemos apuntado la posible identificación de la propiedad de Nicolás de Uribe con esta.

23 A.H.P.J. Legajo 2156, folios 638 al 646. Aunque había sido rematada a favor de Antonio Villahermosa, este cedió sus derechos a don A gustín. El anterior propietario era el Mayorazgo que fundara Doña Catalina de $N$ avarra que gozaba D on Francisco de Carvajal y Mendoza, caballero veinticuatro de Jaén, corregidor y justicia mayor de Córdoba. Datos aportados por el investigador D on Rafael Cañada

24 CAÑ ADA Q UESADA, R. “Linajes N obles... ” p. 362.

25 Estos son:D on A gustín Tiburcio U ribe-Salazar, Caballero Veinticuatro de Jaén y alférez mayor de ella, Maestrante de la Real de Granada, Alguacil Mayor del Santo 0 ficio de la Inquisición, Señor de la Casa de Uribe, Comisario para la Jura del Príncipe de Asturias el año de 1789, nacido en Jaén el 14 de abril de 1762 que fue bautizado en San Andrés; D on A gustín de Uribe-Salazar y Jódar, también se bautizó en San Andrés, y como Coronel de Infantería y figura retirado ya en Jaén. Fue, además Administrador de la Santa Capilla de N uestra Señora de la Inmaculada Concepción de San Andrés de Jaén; D oña María Josefa de U ribe que nació en Jaén, el 3 de noviembre de 1802, y fue bautizada en San Andrés, aunque declara que vive en una casa en San Ildefonso; D on José María de Uribe Salazar y Jódar, nacido el 1 de Enero de 1791, fue bautizado, así mismo, en San Andrés y falleció en 1863; D oña Antonia de la Cruz, que después sería D oña Antonia de Uribe y Porcuna, es otro miembro de la familia que a mediados del siglo XIX "se halla como educanda en el Convento de Santa Úrsula de nuestra ciudad", próximo a la zona que estudiamos; D oña Francisca María de U ribe Salazar y Funau, nacida en Jaén, el 4 de agosto de 1837, también fue bautizada en San Andrés. 
H ay otros U ribe que, si bien están afincados en Jaén, no tenemos, aún, datos que los relacionen con San Andrés, aunque al menos en parte formaron parte de la cadena de propietarios del edificio del que estamos ocupándonos ${ }^{26}$, hasta que el mismo fue adquirido por Esteban Tirado Carrillo y convertido en fábrica de anís, función que tuvo durante la mayor parte del siglo XX. En los años ochenta de este último fueron adquiridas y demolidas por el Ayuntamiento para darle otro destino que hasta ahora ha sido el de solar.

\section{Las Casas de Los Uribe}

Fue en el año 1991 cuando EPSA 27 encargaba estudiar las casas números 1 y 3 de la calle Uribe, hoy Santo Domingo Bajo, con el fin de rehabilitarlas para alojar entre ambas un edificio administrativo. Con el auxilio de dos jóvenes arquitectos de la familia Berges 28 procedimos al análisis objetivo del estado las edificaciones así como al levantamiento de los planos de los dos edificios, además de redactar el anteproyecto de futuro uso.

El edificio marcado con el número 1,0 edificio principal (Lam. 24), ocupaba las esquina de la calle en la plaza de Santa Luisa de Marillac, como consecuencia de poseer un gran patio rodeado de tapias, al cual abría la fachada lateral (Lams. 27 y 28). El otro, el número 3, se levantaba entre el muro medianero del primero (Lam. 29) y el muro lateral de la iglesia del antiguo convento de Santo Domingo. Partiendo de los planos levantados en tal ocasión, vamos a efectuar la descripción de ambos edificios.
En relación con el edificio principal, el marcado con el número 1 , hemos de señalar la exacta coincidencia de sus dimensiones generales en planta baja, ya que considerando la antigua vara de $0,845 \mathrm{~m}$. Sus dimensiones de 21 por 23 varas corresponden a los $17,65 \mathrm{~m}$. por 19,35 m. que obtuvimos en nuestro levantamiento, aproximadamente.

De igual manera, las dos caballerizas y bodega podemos considerar que se corresponden con los dos espacios abovedados que se aprecian en el plano de planta y secciones correspondientes (Fig. 2); los primeros de ellos con acceso desde el patio exterior y el otro, la bodega, bajo la escalera principal 29. En la distribución de la planta baja (Fig. 3) que se presenta en el plano de nuestro levantamiento, distribución adaptada al uso al que estuvo destinada últimamente, es decir, a una fábrica de anís, caben perfectamente las piezas que se describen en la distribución original, de igual modo, a la hora de analizar el plano de planta segunda o planta alta (Fig. 4) y el de terrado o granero (Fig. 5) donde también tienen cabida las piezas en que se distribuían originariamente las superficies de las plantas de nuestro levantamiento.

Hemos consultado la cartografía correspondiente al vuelo fotogramétrico realizado por CETFA en mes de julio de 1985, para el Ayuntamiento de Jaén y la hoja de esta zona de trabajo del famoso Plano Revenga, este último nos muestra, con toda claridad, que las casas con fachada a la actual calle de Santo Domingo eran las que se marcaban con los

\footnotetext{
26 Son: Don José Maria de Uribe-Salazar y Funau que fue abogado y Decano del llustre Colegio de Jaén y alcalde de nuestra ciudad en dos ocasiones, nacido en Jaén en 1818, fue propietario del Castillo de Santa Catalina de Jaén (Cañada 2006:371); Doña María del Rosario Uribe Salazar y Funau, nacida también en Jaén el 7 de Febrero de 1829; D oña Carolina U ribe Salazar y Funau, nacida en Jaén el 8 de mayo de 1850; D oña Matilde de Aragüete y U ribe; D on A gustín de U ribe Salazar y Funau, natural de Jaén, nacido el 19 de octubre de 1835; D on A lberto Cancio Uribe, corredor de comercio, fallecido en Jaén 16 de mayo de 1925. Por último Don A gustín José de U ribe Salazar y Vázquez, nacido en Granada en 1845, abogado, casado en Jaén en 1874, heredero de su tía doña Josefa U ribe Fernández que estaba viuda y sin hijos, y que testó el 20 de noviembre de 1891 (Cañada 2006:377) "manifestando que vivía en casa de D. José de Uribe Funau en la calle de su apellido, inmueble número 1, declarándose hija de D. José de U ribe y Jódar. Siendo esta la última conexión que nos consta de la familia Uribe con el inmueble, ya que a partir de ese momento no tenemos datos, la casa o casas pasarán a ser propiedad de la FamiliaTirado, concretamente D on Esteban Tirado Carrillo, para ser fábrica de A nís.
}

27 Empresa Pública del Suelo de Andalucía.

28 Miguel Ángel Berges y Jacobo Berges Roldán

29A.H.P.J., C.M.E. Legajo 7792 
números 2, 4, 6, 8 y 10 que limitaban por el oeste la casa principal de los U ribe. Presumimos que la que ocupaba don Diego Manuel Messía, un descendiente sin duda de don Fernando Messía de la Cerda, al que vamos a suponer el constructor de la casa principal, sería la marcada con el número 10 , la de mayor superficie, la que don Diego Manuel ocupaba cuando alquila tal casa principal de la calle de los Uribe a uno de ellos ${ }^{30}$. Dicha casa es precisamente donde tras su demolición, se ha puesto de manifiesto, con las excavaciones realizadas bajo la dirección de $\mathrm{D}$ a Angela Esteban, que fue construida a su vez sobre uno de los palacios de la ciudad islámica ${ }^{31}$. Tenía un patio que lindaba con la casa principal ${ }^{32}$, la número 1 de los Uribe, de la que venimos hablando. A travesando dicho patio, las excavaciones han puesto de manifiesto la existencia de una conducción de agua potable que, proviniendo de un raudal que discurría por la actual calle de Santo D omingo y teniendo su origen en el Raudal de la Magdalena, alimentaba a la casa principal o casa número 1 de la calle de los U ribe, desaguando precisamente en lo que últimamente fuera el lavadero de dicha casa.

En el año 1994 se efectuaron también excavaciones ${ }^{33}$ de urgencia en esta última casa antes de su demolición, cuyos resultados desconocemos. En los últimos años, después de realizada esta, se está llevando a cabo una intervención sistemática ${ }^{34}$. A unque tampoco conocemos los resultados, lo que se observa parece poner de manifiesto que el palacio árabe antes mencionado pudo ocupar parte del solar correspondiente a la casa número 1 de la citada calle de los U ribe y algo más, como manifestaremos más adelante.
Centrándonos de nuevo en esta última casa, hemos de decir que su patio lateral con fachada a esa calle y a la actual plaza de Santa Luisa de Marillac, patio con una superficie de más de 300 metros cuadrados, bien pudo ser huerto de la citada casa, desde donde se accedía a las caballerizas situadas en el subsuelo de dicho edificio, terreno como ya hemos visto lo compró don Agustín Ignacio U ribe-Salazar y Buenache. Q uien también compró las casas marcadas con los números 6,8 y 10 de la calle Santo Domingoen el año 1789, compras que, como ya hemos dicho, ponen de manifiesto el paso del edificio principal a manos de la familia Uribe tras haber sido alquilado en su día por su propietario inicial, don Fernando Messía de la Cerda, el cual se retiraría a vivir en la casa número 10 ya mencionada anteriormente.

La planta de la casa-palacio de los Uribe responde a las trazas de la mayoría de las edificaciones que desde el S.XVI se levantaron en nuestras ciudades españolas y también en $\mathrm{H}$ ispano América, para albergar en su interior no sólo a destacadas familias sino a todo tipo de instituciones públicas, planta adaptada a las necesidades de la arquitectura civil y religiosa cuando no igualmente a la militar. Se trata pues de una edificación en torno a un patio central porticado de planta más o menos cuadrada conformado por cuatro naves (Lams. 30-33), una de ellas constituyendo con su muro exterior la fachada principal de la casa, donde se abre el hueco de acceso desde el cual se atraviesa la primera crujía para acceder al patio. El eje que podemos trazar en el acceso se quiebra ortogonalmente en tal espacio abierto, para constituir el eje de la caja de escalera (Lams. 34-35), esta de apreciables dimensiones, que

30 Casa que aparece en el C.M.E. como accesoria al convento y que éste la utiliza para ampliar sus dependencias. Legajo. 7782 . Podemos suponer que la comprara el administrador.

31 A.H.P.J. C.M.E. Legajo 7782.

32 A.H.P.J. CATASTRO MARQ UÉS DE LA EN SEN ADA. Legajo 7792.

33 CAN 0 CARRILLO,J. Intervención arqueológica de urgencia en la casa de los U ribe, Jaén. Archivo de la Delegación de Cultura. Jaén, 1994. Expediente solicitado al Servicio de Bienes Culturales de la Delegación de Cultura de Jaén, el 8 de enero de 2008, que aún no hemos podido consultar.

34 En la actualidad se está llevando a cabo una intervención arqueológica en dicho espacio, dirigida por Mercedes $\mathrm{N}$ avarro y Vicente Barba. 
aloja de manera clara y expresiva el conjunto de peldaños y mesetas necesarios para enlazar verticalmente las dos plantas nobles en las que se desarrolla la vida y el programa interno distribuido en la edificación (Lam. 36).

Esta tipología, en ocasiones, se completaba con una serie de construcciones de inferior categoría destinadas al alojo de la servidumbre y al desarrollo de faenas domésticas que precisaban llevarse a cabo al aire libre en un patio de servicio de inferiores dimensiones (Lams. 37-39).

Igualmente, una vivienda accesoria adosada a la edificación principal se destinaba a la familia del administrador de la heredad ${ }^{35}$.

El edificio principal se completaba con una tercera planta bajo los faldones de la cubierta (Lams. 40-42) donde se almacenaban y ponían a secar productos destinados a la alimentación estacional.Y cuando las características del suelo lo permitían, sótanos y bodegas excavadas en el subsuelo de la planta baja no sólo guardaban las cosechas de aceite y vino, sino que su aire húmedo ascendente refrigeraba toda la casa en los largos y calurosos veranos giennenses, prestación gratuita natural ya olvidada en nuestra arquitectura doméstica.

Como ya se ha dicho, las edificaciones de esta parte alta de la ciudad contaban con la correspondiente dotación de agua procedente del raudal de la Magdalena, que la casa de los Uribe tenía la suya a través de una conducción que atravesando la casa número 10 de la calle Santo Domingo, desaguaba en la zona del lavadero donde debió haber el aljibe que almacenara el agua de la dotación. Esta entrada de la conducción aún pudimos verla con ocasión del levantamiento de los planos del edificio, entrada que hemos reflejado en el plano de planta baja.

Volviendo a las características constructivas de este tipo de edificación descrito, hemos de añadir la sabia resolución de la iluminación, y también de la ventilación de cada una de sus piezas o dependencias, aún cuando la casa estuviese construida entre medianerías, en el peor de los casos, y no digamos si además la edificación contaba con más de una fachada 0 se trataba de una construcción aislada, casos en los que resultó fácil guarnecer las esquinas mediante cuerpos torreados que hablaban de ostentación y poderío.

Esta casa de los Uribe disponía de una fachada lateral que abría al patio o huerto en su lado izquierdo, como puede verse en las fotos y en los huecos que se abren en las plantas del edificio correspondiendo a la nave izquierda (Lams. 27 y 28). De todas maneras, la galería perimetral de la planta principal y la zona de pórtico bajo ella y en la planta baja, aseguraban el acceso a cada una de las dependencias de la casa y la luz suficiente para su iluminación, en contraste con la opacidad del muro de fachada principal donde el mayor de sus huecos, un balcón de apreciable dimensión y de antepecho de hierro forjado de elegante sencillez sobre portada de gran simplicidad, marca el eje primario de la composición del edificio, enfatizado con el escudo de armas de los Uribe (Lam. 24) (CAZABÁN 1923:232).Tres arquitos bajo el alero simple, con dicho escudo, bajo el vuelo de la repisa del citado balcón marcaban el carácter de sus ocupantes, pertenecientes a una burguesía agraria.

El patio principal, muy reformado por la solución ya sabida de cerrar con fábrica la galería alta, era de elegante proporción, conseguida con columnas de orden dórico que soportaban zapatas y vigas de madera. La cubierta leñosa del edificio, cubierta de par y nudillo y tirantes (Lams. 40-42), con faldones de teja árabe sobre ripia de cañizo y barro, cubierta empleada en zonas con abundancia de madera, constituía un ejemplo bastante interesante del sistema de cubrición empleado en nuestra arquitectura popular.

35 En este caso sería Don Agustín de Uribe. 
Esta tipología constructiva que acabó siendo tan jaenera, se completaba como hemos apuntado anteriormente con otras áreas construidas y destinadas a la servidumbre, entonces tan normal y necesaria en cualquier casa de cierta superficie o categoría, áreas en torno a un segundo patio donde se desarrollaban todas aquellas tareas domésticas propias de cada estación del año o del quehacer diario, tales como la matanza del cerdo o la confección de conservas vegetales. El patio, el lavadero y la entrada en la casa del raudal de la Magdalena en su parte asignada al domicilio, constituían el área húmeda de la casa, completada con el retrete y la salida de ellas de las aguas fecales.

A veces, la edificación principal poseía la casa acceso ria que, como ya hemos dicho, solía ser el domicilio del administrador general de las fincas de todo tipo, de cuyas rentas vivía la familia. La casa número 3 de la calle de los U ribe, entre la número 1 y la iglesia de Santo Domingo, parece ser que desempeñaba este papel. Casa de dos plantas de dimensiones y distribución que según la descripción del Catastro estaba situada en la misma calle y declarada como otra propiedad de D. Diego Manuel Messía, utilizada como vivienda y alquilada a Don Agustín de U ribe en 16 ducados, y que tenía la siguiente distribución: en bajo portal y cocina, en alto tres cuartos un terrado; y unas dimensiones de nueve por catorce varas.

Un dato rotundo a la hora de ubicar una propiedad son sus linderos y cuando esta se encuentra junto a un edificio singular nos facilita mucho la tarea de recomponer el espacio, en este caso el propietario declara que linda por arriba con la iglesia de Santo Domingo y por abajo con otra propiedad de Don Diego Manuel Messía, datos a partir de los cuales podemos ir completando la manzana ${ }^{36}$. Coincidente to do lo dicho con los datos obtenidos en el levantamiento de los planos de dicho edificio que hicimos en su día.
0 tra propiedad, en este caso perteneciente al Convento de Santo Domingo (RAMÍREZ, 2003) está localizada en la Calle Maestra Baja o de Santo Domingo, nuevamente el edificio da nombre a la calle, y encontramos los to pónimos de Santo Domingo Alto y Bajo en las dos calles que delimitan el espacio del Convento, aunque la segunda pasará, posteriormente, a llamarse de los Uribe, siguiendo la pauta de nombrar algunas calles con los nombres de personajes ilustres que tienen casa en ellas, como ya hemos dicho anteriormente. Este es otro caso de fácil localización en el plano ya que linda por arriba con la iglesia de dicho convento y por abajo con casas de D. Juan Robles Pacheco. Con unas dimensiones de ocho varas de frente por siete de fondo, constaba de corral, cocina y un cuarto en planta baja; y en alto un dormitorio y una cámara. En la declaración de bienes del convento para el Catastro añade "lo qual dicha casa / el convento ha determinado entrarla en el pa/ra serbizio de la Iglesia zerrada la puerta" 37 .

\section{EL CONVENTO}

El convento de Santa Catalina de A lejandría o convento de Santo Domingo, fracasada antigua U niversidad de Jaén, Hospicio de Hombres, Archivo Histórico Provincial, denominaciones todas aplicables al edificio del que pretendemos escribir cuanto hemos llegado a conocer de él, tanto desde el punto de vista histórico como desde el arquitectónico y constructivo (GALERA 1979; O RTEGA, 1967; HUERGA, 1992).

Para ello, ineludiblemente hemos de situarlo en su contexto temporal e histórico tan largo e interesante, abarcando unos cuantos siglos de existencia, en el transcurso de los cuales su destino inicial fue discurriendo por derroteros tan bien definidos como plenamente caminados para llegar a sus presentes días.

36 "La estructura de las parcelas de los planos de los años 70 y 80 muestran una organización peculiar que abona la idea de una fragmentación tardía de una gran propiedad, aunque es necesario un estudio mucho más detallado" (SALVATIERRA 2007) (Ver también:TRILLO, 1992 y VAQ UERO, 1999).

37 A.H.P.J. C.M.E. Legajo 7782. 


\section{Breve reseña histórica}

El convento de religiosos de la 0 rden de Santo Domingo, denominado de Santa Catalina Mártir, fue fundado por el rey Juan I, sobre unos palacios que habían sido de los reyes moros, concediéndoles agua en abundancia (O RTEGA, 1967). Siguiendo a O rtega Sagrista hemos recogido la carta en la que aparece el testimonio más fiel y rotundo de que el edificio del convento está asentado sobre el palacio árabe, punto este que siglos después se verá constatado por la arqueología (SALVATIERRA 2007).

"Nos el Rey, mandamos a Vos, el Concejo, cavalleros, Alcaldes, Alguacil y Hombres buenos de nuestra ciudad de Jaén que recibades en dicha ciudad y todos sus términos, a los Frailes de la Orden de Santo Domingo de los Frailes Predicadores. Es nuestra voluntad que hagan en la dicha ciudad, en los nuestros Palacios, M onasterio de la dicha Orden, que rueguen por Nuestra vida y N uestra salud $\mathrm{y}$ de los Infantes Nuestros hijos. Facta Carta en Madrid a veintisiete de octubre de mil cuatrocientos y veinte años" (1382) ${ }^{38}$.

0 rtega nos dice que estos palacios debieron conservar la edilicia morisca y que sobre él debieron adaptarse las estructuras de la primera iglesia del convento, dedicada a Santa $C$ atalina, aunque en el siglo XVI aún quedaban edificaciones árabes, que desaparecieron con la obra renacentista.

Lo que quedó, ahora sabemos lo que fue, si no todo, ya que no sabemos los restos que puedan quedar bajo el convento, sí al menos unas estructuras que han permitido al $D r$. Salvatierra aproximarnos al pasado de dichos palacios, haciendo buenas las palabras de O rtega Sagrista que, al referirse a los restos enterrados del palacio decía: “... haría falta una investigación a fondo para descubrirlo" 39 . Restos pertenecientes a la parte del palacio sobre la que más tarde se edificará la ya citada casa número 10 de la calle de Santo D omingo, y que el Dr. Salvatierra ha fechado en época o meya y almo hade.A demás del rico tesoro del agua de la Magdalena que alimentaría fuentes y baños, se ha documentado un estanque en la excavación (ESTEBAN 2003; SALVATIERRA 2007).

En el siglo XVI convento e iglesia sufren una ampliación, pero ya adaptándose al estilo de moda, el Renacimiento, con lo que desaparecieron los últimos vestigios árabes de los edificios que lo componían. En 1582 se hizo la portada principal dirigida por A lonso Barba, discípulo de Vandelvira, aunque las esculturas que la adornan son posteriores, de 1664. Junto a la portada se alzaba la espadaña o campanario del convento (Lam. 43). El templo fue consagrado el 24 de septiembre de 1578. El claustro, que hoy se conserva, fue una obra del siglo XVII, atribuido a Eufrasio López de Rojas (Fig. 12). La parte inferior está formada por arcos de medio punto sostenidos por columnas pareadas y escudos de la 0 rden de Predicadores de España. La parte alta está construida con sillares, con balcones y ventanas con motivos barrocos. El 18 de octubre de 1629 fue fundada la U niversidad de Santa Catalina Mártir (GALERA 1979; O RTEGA, 1967; HUERGA, 1992).

\footnotetext{
38 Tanto del Rey Juan I como de su madre Doña Catalina, cuyo nombre coincide con el de la patrona de Jaén, y con el de la advocación bajo la que se puso el convento de Santa Catalina Mártir, donaron mercedes, gracias y limosnas para el mantenimiento del convento. Entre ellos 40.000 maravedís con los que además se compraron diversas propiedades. El caballero veinticuatro de Jaén Juan Cerezo, dedicó toda su hacienda a una fundación pía con lo que se pudo ampliar los estudios. Tras esta ampliación de estudios a los seculares, que hasta entonces había sido sólo para los religiosos, se abrió una puerta a la calle principal, vecina a las clases donde se leía, para que no transitasen por el convento. Este convento llegó a ser el más rico de Jaén gracias entre otras donaciones a los bienes de la fundación Peñalosa. Relacionado con la constitución de esta fundación encontramos al licenciado Pedro López N ieto, que aparece en documentos notariales relacionados también con las fundaciones de religiosas dominicas.Vid. CAZABÁN LAGUNA, A. "La fundación Peñalosa" DON Lope de Sosa año 1916. P. 276.Vid. RAMÍREZ DE JUAN M. E. “A portaciones documentales para el estudio de los Conventos de Dominicas de Jaén: Santa María de los Ángeles y la Purísima Concepción". Gienium, 2006.

39 Su propuesta era sin duda ideal, pero ahora sabemos que no estaba alejada de la realidad Suponía la existencia de arcos de herradura y lobulados; columnas y celosías de mármol, alicatados y yeserías, frisos, artesonados de maderas con bellas policromías, estanques, patio de naranjos con arquerías abiertas, alberca todos los elementos, en resumen, de la arquitectura califal cordobesa
} 


\section{El edificio}

Para po der hablar en líneas generales acerca del emplazamiento y de la configuración de esta interesante edificación dentro del casco histórico de la ciudad, hemos de precisar que ocupa casi la totalidad de la manzana limitada por las calles de Santo Domingo, Arquillos y de los U ribe (Figs.9-10; Lam. 43; 57), levantado sobre uno de los aterrazamientos de la reforma almohade de la ciudad romano-omeya, según el profesor Salvatierra (2007:15-17), buscando la planimetría del terreno necesaria para poder desarrollar un inicial programa en torno al gran patio claustrado.

Contamos para la descripción general de esta edificación con los planos levantados en el mes de julio de 1965, que firman los arquitectos provinciales D on Francisco de Paula López Rivera y Don Manuel Millán López, tanto de sus plantas como de la sección transversal dada por el patio principal, planos que la Diputación Provincial me facilitó cuando mis primeros trabajos en el convento de Santo Domingo cuatro años después (Figs. 11-14).

En el plano de planta baja de dicha edificación puede apreciarse la traza ya conocida de un gran patio principal con pórticos a sus cuatro lados, con diversos escudos (Lam. 45-50), patio configurado por el importante volumen de la iglesia a su costado sur (Lam. 51) y naves longitudinales a los costados norte y este, mientras que el límite de su lado oeste lo compone un muro de tapial que contiene el aterrazamiento antes indicado, lo que determina la cota general del conjunto edificado a unos tres metros por debajo de la rasante de la calle Santo Domingo.

Si analizamos la planta de la iglesia (Lam.52), es fácil observar una cabecera inicial constituida por un presbiterio entre dos capillas laterales, una de ellas modificada en su día, ante el que se abre un importante crucero que aloja un espacio central cubier to por una cúpula semiesférica, que sirve de transición forzada con la nave única y central del templo entre capillas laterales, nave en cuyos pies se dispone el coro alto (Lam. 53) y que se cubre con otras dos cúpulas semiesféricas. En el muro de cierre de esta nave se abre el primitivo acceso principal al templo, que se guarnecía con importante portada atribuida a la labor de Alonso Barba, cuyo emplazamiento fue adelantado en su día hasta enrasarlo con el resto de la fachada oeste de la edificación, como consecuencia de su estado de ruina conjuntamente con el de la espadaña (Lams. 54; 55; 56). Esta iglesia contaba con un segundo acceso, éste lateral, desde la calle de los U ribe (Lam. 57).

En el lado opuesto a esta entrada, es decir, en el costado norte del crucero, otra puerta conduce a la sacristía (Lam. 58) y a la sala capitular, ambas con huecos de luces al patio principal. La nave longitudinal que cierra el lado norte de dicho patio tiene a su vez luces a un patio de servicio o patio de atarazanas, patio cerrado lateralmente por otra nave paralela a la anterior que tiene fachada y hueco de acceso a la calle Arquillos. Este acceso fue siempre entrada de servicio al conjunto de la edificación.

Entre la nave que cierra el patio principal por su lado este y la calle de los Uribe existe otro patio denominado primer patio, conformado a su vez por naves de doble crujía a las calles aludidas y Arquillos, un patio ajardinado donde se abría la puerta principal de acceso al conjunto (Lam 59 y 60), la comunicación con la iglesia y otras dependencias tales como la caja de la escalera principal. So bre este área del edificio existía una entreplanta de distribución compleja, comunicada con la planta inferior y con la primera planta por medio de la escalera principal y otras más de naturaleza privada y secundaria, para acceder a lo que parece eran dormitorios generales y residencia de monjas.

La planta primera se extendía so bre la totalidad de la superficie del edificio, excepto en el volumen interior de la iglesia, planta que parece estuvo dedicada a dormitorios generales que ocupaban incluso las galerías altas del claustro en sus cuatro lados.

Por último, bajo la cubierta a dos aguas se fueron habilitando espacios habitables para 
destinarlos a más dormitorios generales, entre ellos el denominado camarón que aparece con frecuencia en distintos expedientes que hemos consultado ${ }^{40}$ y que, sobresaliendo sobre las demás cubiertas que cerraban el patio principal de alguna manera rompía el juego de los faldones que vertían a dicho patio.

\section{Sistema constructivo}

A través de los documentos consultados ${ }^{41}$ sobre el edificio de Santo Domingo en los años que, tras la desamortización de Mendizábal se dedicase a Hospicio de Hombres ${ }^{42}$, hemos podido conocer los materiales empleados originariamente en la construcción de las distintas áreas del inmueble, estado de conservación, zonas en ruina, distribución de sus espacios, reformas y ampliaciones, formas de vida de los asilados, necesidades acuciantes, sistemas de enseñanza, etc.., dado que, como veremos más adelante, se precisó de manera constante la intervención de los arquitectos al servicio de la Diputación Provincial.Todos estos interesantes datos para nuestro trabajo, unidos a los obtenidos en nuestra intervención, primero en una fase inicial de restauración y después en las de adaptación de la mayor parte del conjunto para Archivo Histórico Provincial, nos proporcionó el conocimiento suficiente para saber cómo se construyó Santo Domingo dentro de los sistemas tradicionales constructivos y de los materiales entonces empleados, sin que con ello podamos conocer fechas exactas de comienzos y terminaciones de la totalidad de sus diferentes partes, a excepción de las obras llevadas a cabo en la construcción de la iglesia y del patio principal o claustro, además de las reformas y ampliaciones más importantes y significativas llevadas a cabo desde el año 1816 hasta nuestros días. Así pues, hagamos un recorrido general por sus distintas partes y espacios.

\section{Excavaciones}

La cimentación de muros y pilares de carga fue somera, excavándose el terreno hasta la cota de las primeras arcillas, excavación a todas luces insuficiente como se fue poniendo en evidencia con los recalzos necesarios llevados a cabo a lo largo de los años.

\section{Cimentaciones}

El relleno de las zanjas y pozos de cimentación se ejecutó mediante mampostería to mada con pobres morteros de cal y arena.

\section{Muros}

Los muros de carga de la totalidad de las edificaciones que componen Santo Domingo son de tapia (tapial) de tierra compactada y de 0,60 a 1,00 de espesor, muros que en sus arranques presentan un zócalo de mampostería de factura análoga al cimiento correspondiente.

Dinteles

El adintelamiento de vanos, tanto de huecos de paso como de iluminación en fachadas se resolvió mediante rollizos de madera de pino, solidariamente unidos mediante to miza de esparto.

\section{Pisos}

Los forjados de piso se resolvieron con vigas de madera generalmente en rollizos y singularmente con vigas escuadradas allí donde la alfarjía quedaba vista. Sobre tales vigas, se tendían bovedillas de yeso, 0 ramaje de boj principalmente, sobre el que extender el relleno 0 alcatifa niveladora, para soportar la torta de yeso que bruñida, constituía el pavimento, generalmente teñido de almazarrón, cuando no de baldosa hidráulica.

\section{A.D.P.J. Ex no 3788/7, año 1925.}

41 A rchivo de la Diputación Provincial de Jaén. Los documentos consultados aparecen junto a las intervenciones de los distintos arquitectos provinciales que se detallan en el texto. Q ueremos agradecer a su directora Doña Adelaida García Sánchez que nos haya facilitado y hecho tan grato nuestro trabajo de búsqueda en dicho archivo.

42 Dentro del grupo de los edificios provinciales de la Beneficencia dependientes de la Diputación Provincial, tales como el Hospital, el Hospicio de Mujeres y la Maternidad. 
Falsos techos

Los cielos rasos o zarzos se constituían con cañizo, fabricado en rollos con medias cañas atadas con tomiza que se sujetaba a la viguería de madera mediante su clavado con tachuelas, para acabarse con un tendido de yeso negro por su cara inferior.

\section{Cubiertas}

El sistema de cubrición seguía igualmente el tradicional en nuestra ciudad, es decir, mediante cuchillos o formas de madera de pino en escuadrías suficientes; el de cubierta de par y nudillo con tirantes de madera 0 de redondo de hierro forjado, ambos fijados a los durmientes de coronación de muros, cubiertas leñosas generalmente con faldones a dos y tres vertientes sobre los que se empleó la teja árabe sentada con barro sobre enlatado de tabla ripia.

\section{Instalaciones}

En la segunda mitad del siglo XIX las instalaciones de un edificio eran más bien precarias. Pensemos que la energía eléctrica en Jaén comienza a instalarse en los domicilios particulares hacia 1905, que en las conducciones del agua potable aún se utilizaban los atanores de barro, y el plomo como material singular y que la red de desagüe se servía de canales conformados con losas costeras de piedra y cobijas de igual material, que daban lugar a frecuentes fugas que dañaban las someras fundaciones, cuando no se recurría a los pozos ciegos que se limpiaban periódicamente. El caudal de agua potable necesaria en estos edificios de la beneficencia siempre constituyó un serio problema que traía de cabeza a la Diputación y a su personal técnico.

A lo largo de los años de utilización del antiguo convento de Santo Domingo como Hospicio de Hombres ${ }^{43}$ el agotamiento de la capacidad de trabajo de sus distintos materiales de construcción, el aumento de la población interna con la correspondiente necesidad de adecuar espacios para ella, la atención a los más alarmantes estados de ruina de sus distintas edificaciones, la creación de nuevos talleres para el autoabastecimiento y la modernización de planes de formación para todas las edades, van a dar lugar a una continua atención y actuación del arquitecto y su personal auxiliar en Santo Domingo, de tal manera que sus informes, proyectos y cuentas de reparaciones de to do tipo constituyen una incalculable fuente de datos para el conocimiento de la vida y milagros de esta edificación que ha jugado y jugará un importante papel en nuestra historia local.

Los hospicios eran pequeños mundos de personas con carencias de to da naturaleza, que era necesario mantener internada y ocupada en escuelas, talleres de carpintería, telares, fabricando cuerdas de esparto 0 cáñamo, alpargatas, panificando, cocinando, acarreando leña y agua de aquí para allá, así como permanecer en el patio central, tanto en verano como en invierno, faltos de espacio cerrado donde guarecerse. Se trataba de una serie de actividades masificadas que precisaban espacios donde el uso y desgaste así como las incipientes modernizaciones industriales precisaban la intervención del arquitecto provincial, siempre manejando escasos presupuestos. A veces, para abaratar el trabajo en obras menores se recurría a aquellos asilados capacitados para el trabajo y con un mínimo de conocimiento de los oficios de la construcción. Y siempre, se empleaban materiales procedentes del derribo de casas pertenecientes a la propia Beneficencia. Materiales de demolición del Convento de San Francisco o los sobrantes de la obra del nuevo Palacio Provincial constituyeron el gran almacén al que recurrir para trabajos de pequeña índole, tales como sustitución de vigas o retejado de cubiertas.

\section{El Convento de Santo Domingo y los arquitectos provinciales}

La Diputación provincial ha tenido entre sus funcionarios, desde el año 1860, a una serie de arquitectos que han debido velar por el

43 En la primera mitad del siglo XIX, después de la desamortización de Mendizábal. 
buen estado de sus edificios y que han dejado tanto en nuestra ciudad como en la provincia una serie de edificios salidos de sus respectivos tableros de dibujo que hoy día forman parte de nuestro patrimonio arquitectónico. El cargo de arquitecto provincial lo ostentaría por primera vez D on José María Cuenca Hostalot, al cual tocó la tarea de rescatar la profesión de las manos de maestros de obras, misión que debió crearle una serie de conflictos con las autoridades provinciales, en la que no siempre tuvo éxito inmediato.

Esos arquitectos los podemos encontrar en los documentos referentes a obras llevadas a cabo en los distintos edificios de las casas de Beneficencia que la Diputación ha mantenido entre sus obligaciones, tales como el Hospital de la Santa Misericordia, el Hospicio de Mujeres, Maternidad y el Hospicio de Hombres, principalmente. De este último, establecido en Santo D omingo, vamos a dar noticia concreta a lo largo de los siglos XIX y XX, es decir hasta el final de su misión de acoger en sus espacios a tanto asilado carente de hogar.

Tenemos que señalar que la mayoría de las actuaciones que los arquitectos habrían de llevar a cabo en este edificio son las que hoy día se califican de obras menores. Con ellas se acudía a remediar atranques en las tuberías de barro cocido, atanores, del agua potable, bastante escasa de dotación en los dos hospicios, y a los atranques en los escusados o retretes, problemas ambos que adquirían seriedad bajo muros de carga de tierra, tapial, casi carentes de cimentación y que derivaban siempre en serios asentamientos de muros y correspondientes grietas denunciadoras de ruinas.

El agua, procedente de lluvias torrenciales, era el origen de constante preocupación para tanta superficie de cubiertas del edificio, la cual acababa filtrándose en la testa de tales muros, desprendiendo soalas que ponían en peligro la vía pública y eran rápidamente denunciados al
Ayuntamiento, pudrían las cabezas de empotramiento de las asnas o costaneras, maderas en rollizos que por su gran peso cedían además bajo el añadido de la teja y la alcatifa cargada de agua que generaban serios empujes y grietas en ambos muros de las crujías o naves, los que iniciaban su desplome.

U na curiosa manifestación de ruina, un tanto frecuente que se producía en las dependencias de planta baja de esta enorme edificación, era el desprendimiento de los zócalos construidos con pesadas losas de mármol blanco de Macael de grandes dimensiones y espesor, simplemente tomadas al muro de tapial mediante mortero de cal y arena o con auxilio de grapas metálicas de alambre no galvanizado, la humedad del subsuelo que se trataba de ocultar con tales zócalos, ascendente por capilaridad en la masa terrosa del tapial, daba lugar a que tan pesado recubrimiento se desprendiese, lo que determinaba un serio peligro para personas tales como ancianos y niños sentados próximos a la pared, y mucho más a los dormitorios.

Va a ser en el año 1932 cuando se comenzarán a sustituir en los huecos de ventana sus carpinterías de madera por las novedosas de perfiles metálicos de Mondragón, de cierre y manejo más fácil que el que podían determinar las ventanas de madera, hinchadas por el agua de lluvia y alabeadas a lo largo de los años. Generalmente, los pavimentos eran terrizos en planta baja, siempre necesitados de reparaciones o sustituciones con baldosas ligeras hidráulicas.

Tras la breve y azarosa actividad de Cuenca Hostalot, fue Serrano y Salaberri quien iba a ocupar el cargo de arquitecto provincial. Su intervención como tal en el edificio que nos ocupa se debió desarrollar entre los años 1861 y $1863^{44}$.

De Serrano y Salaberri se conserva su documento más completo en relación con

44 A.H.D.J. Exp. 2157/12, de 1861 y 3635/1 de 1863.Teniendo igualmente ocasión de iniciar los trabajos de adaptación del ex-convento de San Francisco para palacio Provincial y de reformar nuestro primer parque urbano, llamado entonces Paseo de la Alameda. 
Santo Domingo, cuyo título es "Proyecto para la continuación de la galería del Hospicio de Hombres" fechado el 6 de Noviembre de $1861{ }^{45}$, en el cual "D on Vicente Serrano y Salaverri, Arquitecto de la Real Academia de Bellas Artes de San Fernando, procedente de la Escuela Especial y jefe de obras civiles", recoge todo cuanto ha podido registrar, en su primera intervención en nuestro edificio, de estados de ruina constructiva y de necesidades internas mínimas y necesarias para aquellos 536 refugiados varones de todas las edades que, carentes de hogar y medios, cuidados por las Hermanas de la Caridad. Este proyecto, verdadera joya documental y serio trabajo que todos los arquitectos giennenses debieran alguna vez conocer, constituye no sólo un ejemplo de proyecto completo en todas sus distintas partes, sino también un verdadero tratado de construcción antigua y de condiciones de empleo de materiales ${ }^{46}$.

El proyecto se presenta dividido en dos partes: las obras necesarias para reparaciones $y$ atajo de ruinas y las que se han de efectuar como obra nueva. En estas se incluyen las de "establecer fácil comunicación a la escuela de instrucción primaria y ensanche del refectorio (comedor), así como la conclusión de las obras empezadas en la galería del patio primero, tales como construcción de pavimentos bajo y principal, machones de escalera comunicada con la principal del edificio, cubiertas, revoco de paredes, apertura de vanos en el dormitorio inmediato llamado de San José, colocación de antepechos y unión de la cubierta nueva con la de la galería que forma escuadra en el patio primero. En el mismo local en que se encuentra el lavadero provisional, hay precisión de construir un conjunto de tres pilas con doce piedras lavaderas". El presupuesto general de este proyecto ascendió a 94.417 reales y 85 céntimos ${ }^{47}$.

El plano (Lam. 61) muestra la obra a realizar y hemos marcado en el de la planta baja del edificio de Santo Domingo, la situación de la parte que se eleva y la del lavadero reformado. A fortunadamente, las pilas del lavadero se pudieron salvar del expolio y más tarde se incorporaron a la jardinería de dicho patio primero ${ }^{48}$.

Tras haber cesado Serrano y Salaverri en su cargo de arquitecto provincial, le sucederá D on Jorge Porrúa Moreno que, entre los años 1869 y 1881 seguirá cuidando del edificio de Santo Domingo,

La escasa dotación de agua potable disponible para el Hospital de Hombres se venía resolviendo gracias a los pozos de las casas de la vecindad o la que se traía con cántaros desde el manantial de La Magdalena, semillero de disputas a la hora de llenarlos. Hay un delicioso proyecto de Porrúa Moreno para un pozo (Lam. 62) que se abrió junto al lavadero, tras hacerse unas catas y encontrar agua a los tres metros de profundidad, fechado el 30 de A bril de 1870, obra presupuestada en 228.000 escudos que vino a resolver el problema aludido. Igualmente, adecua uno de los talleres, de los que había exceso, para habitación donde refugiar durante el día a todos aquellos que, levantados al amanecer, carecían de actividad hasta las oraciones de la noche en la iglesia.

La obra mayor que este arquitecto lleva a cabo en el edificio de Santo Domingo fue la correspondiente a la actuación en el cuerpo del edificio situado en la nave norte del patio

45 La Escuela Superior de Arquitectura de Madrid, dependiente de la Real Academia de Bellas Artes de San Fernando, se crea en el año 1840.

46 A.H.D.J. Exp. 3635/1.

47 En aquellos años un oficial de albañilería ganaba al día 10 reales, 8 su ayudante, 7 el peón mayor, 5 el menor, 14 el oficial cantero, 9 su ayudante o folleta, encargado de encender y mantener la fragua con el fuelle. De igual manera, el arriero percibía 10 por cada caballería mayor (caballo, buey y mula) y 6 por la menor (asno). Una peseta equivaldría después a cuatro reales 0 cien céntimos.

48 A la vez que redactaba el 8 de enero de 1870 el proyecto de continuación del palacio presidencial, y el 30 de Junio el nuevo y definitivo proyecto de este palacio y nos dejaba también la primera reforma que se acomete en la plaza del Pósito. 
principal, en la que estaban en ruina los machones que soportaban el forjado sobre dicha crujía y que fueron sustituidos por columnas de fundición (Lam. 63). La planta baja de dicha nave estaba dividida longitudinalmente en dos talleres de tejidos y un entresuelo, sobre ellos se encontraba una sala denominada de las cunas (Lam. 64). Esta obra se llevó a cabo según proyecto fechado el 30 de Julio de 1875. Q uizá fuese la colocación de tales columnas la primera ocasión de emplear este nuevo material en la estructura del inmueble, salvo el uso de las llaves metálicas en el cosido de muros deshojados ${ }^{49}$.

Es en el año 1881 cuando se nombra al cuarto arquitecto provincial, D on Ricardo Marcos y Bausá, cuya actividad como tal concluye en 1883 , muriendo al año siguiente ${ }^{50}$.

En relación con su actividad en el edificio de Santo Domingo, se redujo ésta a la de conservación o pequeñas obras de reparación de techos en algunas de las salas, tales como en el taller de zapatería en la llamada de "San Lázaro" y en la enfermería de las Hermanas de la Caridad ${ }^{51 .}$

En el año 1885 encontramos un nuevo arquitecto al servicio de la Diputación Provincial, Don Justino Flórez Llamas, que también sería el arquitecto municipal y diocesano ${ }^{52}$. En sus últimos años fue abando nando cargos o ficiales por enfermedad, hasta su muer te en $1927^{53}$.

Será en el año 1924 cuando, por renuncia de Flórez, la Diputación nombraba a Luis Berges
Martínez para el cargo de arquitecto provincial. $\mathrm{N} o$ vamos a dar noticia de su actividad profesional al margen de la que señalamos ahora en relación con Santo Domingo, dado lo reciente de la publicación del libro titulado "A rquitecto Berges 1891-1939" donde se puede encontrar sobrada noticia. Q uizá fuera la intervención de Berges en la fachada principal de la Iglesia de Santo Domingo lo más destacado sobre este edificio que hiciese en aquel año de 1924. Con motivo de encontrarse dicha fachada en ruina e igualmente la espadaña sobre ella, circunstancias ya denunciadas hacía tiempo por Alfredo Cazabán, el veedor del Hospicio de Hombres, don Inocente Fé promovió la intervención del arquitecto, dado que estaba en peligro la famosa portada manierista de Alonso Barba.Aún cuando al parecer se habría decidido desmontarla para montarla después en el acceso principal al edificio del Hospicio por la calle de los U ribe, finalmente se decidió adelantar toda la fachada de la iglesia en la calle de Santo Domingo y con ello la portada, hasta enrasarla con el muro que cierra el patio principal claustrado por su lado de poniente, muro de tapial de posible origen almohade que delimita uno de los aterrazamientos creados en la reforma que se llevara a cabo en época musulmana en esta parte de la ciudad.

El abastecimiento de agua potable a los distintos establecimientos de la Beneficencia constituyó en todos los tiempos un serio problema, no siempre debido al caudal sino a la red de reparto y sus constantes averías. Para el Hospicio de Hombres en el edificio de Santo Domingo se disponía de ocho cañones de

49 A.H.D.J. Exp: Porrúa 2175/55, 2177/121, 2177/57, 2177/60, 2178/62 año 1869; 2206/55 año 1870, 3554/3 año 1871, 3554/1 año $1873,3569 / 10$ y $2170 / 77$ año $1875,2164 / 9,3569 / 9,2163 / 10$ año 1880 y 3567/3 año 1881.

50 De su obra nos ha quedado la realización del patio central del palacio provincial, así como las escuelas en la calle Recogidas, ya demolidas a mitad del siglo XX, a su vez construidas en el solar de lo que fuera un hospital de mujeres recogidas, que diera nombre a la calle.

51 A.H.DJ. Exp: Bausá 2174/40, 3569/10 y 2176/107 año 1882, 3567/4 y 2172/84 año 1883.

52 De gran actividad profesional y empresarial, va a dejar muestras de todo ello en nuestra ciudad e igualmente en la provincia, tales como fueron la conclusión del palacio provincial, el matadero Provincial, ya desparecido, el seminario Diocesano, en 1899 que dejará incluso y la manzana de viviendas donde se acomodaran el teatro Darymelia en 1927 y el Casino Primitivo sobre el antiguo Palacio del Condestable Iranzo, lo que diera lugar a la desaparición de la mayor parte del mismo.

$533567 / 5,2205 / 81,2204 / 92$ año $1884 ; 2199 / 3$ año $1885,2168 / 22$ año $1893,3775 / 2$ año $1898,3776 / 6$ año $1901,3776 / 7$ año 1903 , 3785 / año 1913, 3789/15 y 3689/4 año 1917, 3786/15 año 1922. 
agua, en el mes de mayo de 1835, cuando al parecer era convento ${ }^{54}$. En el mes de diciembre de 1866 la dotación era de dos cañones y de dos cañones y dos plumas en el mes de julio de 1872.

En el año 1925 la dotación total de agua potable con que contaba la Diputación se distribuía en nuestra ciudad de la siguiente manera:

Hospital de la Misericordia 14 plumas

Hospital de Hombres 10

Hospicio de Mujeres 10

Palacio Provincial 4

Según el proyecto que Berges Martínez redacta el 7 de Mayo de 1925 y presupuesto total de $13.867,85$ pesetas se trataba con él de sustituir las antiguas conducciones de barro y de plomo por otras de hierro fundido, así como construir nuevos repartidores para todos los tramos de la red

Con obras realizadas en distintos dormitorios a los que se les va a dotar de retretes próximos a ellos, se va a acometer la tarea ineludible de separar a los niños de los ancianos.

Un proyecto, fechado el 11 de N oviembre de 1925, da cuenta de la construcción de una nueva panificadora (Lam. 65 y 66) en el patio con acceso por la calle Arquillos o patio de atarazanas donde se almacenaba la leña y se encontraban los retretes generales. Esta panificadora vino a sustituir al horno que en dicha calle trabajaba casi con exclusividad para el Hospicio.Y otro proyecto en el mismo año redactaría Berges Martínez para reformar la capilla del altar de la Milagrosa en lado de la epístola de la cabecera de la iglesia (Lam. 67). Un interesante Pliego General de Condiciones perteneciente al primero de estos dos proyectos aludidos nos da amplia noticia de los sistemas constructivos que prevalecían en aquella primera mitad del siglo $\mathrm{XX}$, en cuanto a demoliciones, cimentaciones, muros y pilares, pisos de fo rjado, tabiquería, cubiertas, sus armaduras y limas, escaleras, enlucidos, chapados, pavimentos, recibido de cercos, carpintería de taller, pintura, apeos, vallas de protección y rejuntado de muros de fachada 55 .

El 5 de noviembre de 1926 se proyecta restaurar la bóveda bajo el coro, con el fin de habilitarlo como dormitorio ante el creciente de número de acogidos, espacio que con el paso del tiempo acabó siendo la imprenta provincial; escuelas de enseñanza primaria que ampliar con aulas para el dibujo y la música; talleres de sastrería, de tejidos, de zapatería, de esparto y cordelería, de albañilería, de carpintería, de imprenta, que se han de habilitar; lavandería y colandería de la ropa, comedores, la gran cocina como la sala de calderas de un navío, despensa, almacenes de alimentos, la panificadora, leñera, lavaderos, to do en peores condiciones que se han de mejorar. Continuas reparaciones de naves en estado de ruina que se han de habilitar para más y más dormitorios (el de San José, San N icolás, el Camarón, el de los idiotas, el dormitorio para las Hermanas de la Caridad, el de las cunas, etc.) salones para la estancia diurna de ancianos, de niños, modernización de aseos y duchas que iban poco a poco sustituyendo a letrinas comunitarias, porquerizas y corrales, nos dan idea de la atención casi diaria del arquitecto y del aparejador, de cuantas obras realizadas con escasos presupuestos, contabilizados hasta el último céntimo, por cuadrillas de albañiles ayudados de algunos residentes útiles, cuando no se trataba de obras de mayor naturaleza, sacadas a concurso o subasta pública, ejecutadas por contratistas estrechamente controlados.

A Berges Martínez tocaron igualmente intervenciones de mayor importancia en Santo Domingo, como fuera la restauración de las cuatro galerías porticadas que conforman el

54 En la primera mitad del siglo XIX, antes de la Desamortización de Mendizábal.

55 Condiciones constructivas que aquellas irrepetibles familias de buenos albañiles y maestros de obras transmitían año tras año y que tuvimos ocasión de conocer directamente hasta la década de los años 60 del mismo siglo. 
patio principal, las cuatro en estado de ruina (Lam. 68). En la Memoria de sus respectivos proyectos, un año tras otro, se especificaba que las obras se hacían con doble interés: "aumentar el número de dormitorios y la conservación de un conjunto arquitectónico de indiscutible valor y que, como todas las obras de restauración, llevan una lenta marcha, máxime para no privar al Hospicio de todas las galerías altas" las cuales estaban ocupadas por dormitorios, principalmente. En cada una de las pandas o galerías, fue preciso demoler la cubierta, el piso y las bóvedas no estructurales bajo él, para luego ser todo reconstruido con el mismo criterio que presentaba, colocándose nuevos pavimentos y carpinterías de ventanas y balcones. En algunas de estas galerías y a nivel de forjado, cuando nuestra intervención en el año 1969, encontramos tirantes de hierro forjado colocados en aquellos años (Lam. 69), como solución en el ya conocido desplome hacia el vacío del patio, del tramo central de las arquerías, punto débil de ellas por arriostramiento insuficiente, cuyas crucetas de anclaje a la sillería del muro habían hecho estallar (Lam. 70), al aumentar su volumen por oxidación, la rica labra de antepechos y fajeados verticales en el recercado de huecos.

Q uizá sea en las cuentas de las obras de una reforma interior para crear un nuevo salón de música donde vamos a encontrar, por última vez, la firma de este arquitecto el 26 de marzo de 193556 .

Al morir Luis Berges Martínez en el mes de Julio de 1939 irá a sustituirlo en el cargo el arquitecto provincial Francisco de Paula López Rivera natural de Alcaudete el cual, debido a la permanencia prolongada en nuestra ciudad, dejará numerosas obras tanto como conse- cuencia de su cargo en la Diputación como por el ejercicio libre de su profesión.

Al igual que sus antecesores, López Rivera tuvo que atender al buen estado y a cuantas reformas fue necesario llevar a cabo en los edificios de la Beneficencia provincial ${ }^{57}$. En relación con el Hospicio de Hombres, durante el año de 1940 acomete la reparación de la cubierta de la iglesia, así como la del edificio de la panificadora, donde se hacía necesaria reparar el horno, instalación que debía trabajar casi las 24 horas del día para tanta población interna (Lam. 71).

El plan de formación de dicha población se va perfeccionado a lo largo de los años, como hemos podido deducir de tanto expediente consultado. Así, en el año 1944 se organiza un taller de herrería, y para la biblioteca se propone la adquisición de libros, cuyos títulos nos mueve a reseñarlos:

\section{O bras completas de José María Pereda \\ O bras completas de W illiams Shakespeare \\ O bras completas de Gabriel y Galán \\ 0 bras completas de Jacinto Benavente.}

En el año 1948 y en el mes de Julio se pretende una importante remodelación interior como consecuencia de un nuevo programa de enseñanza, remodelación que se fijaba en estos términos: nuevo taller de carpintería a instalar en la antigua leñera.

N uevo taller de imprenta situado bajo el coro de la iglesia, espacio que a su vez servía de comedor de ancianos y de despacho de inspectores.

56 3788/1, 3788/7 y 3791/3 año 1925; 3789/1 y 3790/7 año 1926; 3793/5, 3794/24, 3794/25 y 3795/22 año 1927; 3322/25 año 1928; $3795 / 25$ y 3797 año 1929; 3018/34 y 3803/2 año 1930; 3805/3 año 1931; 57/12 año 1932; 3799/3, 3799/7, 55/26 y 56/6 año 1933; 69/3 y 3807/25 año 1934; 70/12 año 1935; 69/9 y 70/6 año 1936. Después, los años de contienda bélica durante los cuales las Hermanas de la Caridad fueron expulsadas y se abrieron las puertas de aquella institución, cuando los allí recogidos corrieran distinta suerte fuera de la protección perdida, muchos al encuentro de su propia fortuna.

57 A.H.D.J. Exp.3807/30, 3807/33, 3806/6,3834/4,3833/7,12/3,15/1,3834/3, 112/17, 29/48,30/3,3836/3,3837/11,41/9,43/36,35/57,35/66 $3835 / 29,25 / 20,1897,74 / 3,74 / 4,50 / 6,50 / 23,50 / 24,90 / 2,3824 / 2,64 / 7,66 / 4,89 / 15,89 / 5,71 / 27,89 / 4,129 / 4,130 / 13,151 / 46,151 / 80,3868 / 5$, $443 / 3,444 / 3,6232 / 2,257 / 71,6242 / 73 / 261 / 106,481 / 12,39,37 / 52,3882 / 4,6262 / 301,481 / 8,6272 / 400,3935 / 34,3936 / 89,3937 / 1,3937 / 19,3$ $937 / 27,4010 / 53$ Y $5708 / 9$ 
Nuevo taller de electroquímica, montado en un aula de tercer grado.

$\mathrm{N}$ uevas aulas escolares, tres de ellas situadas fuera del edificio, ocupando la casa número 3 de la calle de los Uribe, propiedad entonces de don Esteban Tirado, y desde ella acceder a otra aula de mayores, situada en la planta primera de Santo Domingo. Dos nuevos comedores, ubicados en aulas ya existentes.

N uevo salón de actos, en el entonces comedor.

Nueva clase de dibujo en el que fuera dormitorio de San Vicente.

$\mathrm{N}$ ueva sala de juegos para menores en la carpintería.

N ueva sala de juegos para mayores, en el ala de la vivienda del capellán.

N ueva sala de estudio de alumnos, en parte de una galería del claustro.

N uevo dormitorio de inspectores, en parte de la enfermería y nueva enfermería, reduciendo la existente montada igualmente en otra de las galerías.

Si hacemos reseña de todo esto, que más bien parece un galimatías o trabalenguas para agotar al paciente lector, lo hacemos sinceramente para poner de manifiesto lo que siempre representó un quebradero de cabeza; es decir en una vieja edificación que se construyera para un determinado destino, encajar nuevos programas, crecientes y evolutivos, que dan lugar a nuevos espacios internos que se han de interrelacionar dentro de unos condicionantes físicos existentes y muchas veces difíciles de moldear a nuevas exigencias, principalmente circulaciones tanto en vertical (escaleras) como en horizontal (pasillos o corredores), to do lo cual determina a su vez programas de obras de reforma que superan las de simple conservación del inmueble.

El edificio de la iglesia, enorme y destartalado, reclamaba igualmente atención urgente. De esta manera, en 1946 se redacta un proyecto de consolidación que comprendía la reparación de la cubierta (Lam. 72) y el recalzo en algún punto de sus viejos muros de tapial. Pero será en el mes de noviembre de 1965 cuando se decide su no utilización ante el estado de ruina peligrosa que presentaba. Un proyecto del mes de febrero de 1967 con presupuesto de $336.462,84$ pesetas, redactado por el arquitecto provincial adjunto don Manuel Millán López, fallecido en el año 1978, en plena madurez profesional ${ }^{58}$ trata meramente de reparar y consolidar la citada iglesia de Santo Domingo, con el que se atendió principalmente a actuar en la cubierta, resuelta con cuarenta y un cuchillos de madera de par y nudillo y tirantes metálicos a la altura del solero, en uno de los cuales se encontró reseñada la reparación llevada a cabo en octubre de 1951. En esta reparación de Millán, por causas del presupuesto económico insuficiente, la mayor superficie de la cubierta de la iglesia, resuelta como es lógico con teja cerámica curva, fue sustituida por placas onduladas de fibrocemento que, de alguna manera hicieron perder la unidad constructiva del amplio paisaje de cubiertas árabes que caracterizaba entonces a aquella parte del casco antiguo de la ciudad.

La Diputación Provincial debió llegar al convencimiento de que aquel histórico caserón de Santo Domingo no daba para más en su noble tarea dentro de la Beneficencia, como lo demuestra que en el año 1959 se subastan las obras de construcción de un grupo escolar denominado de Santo Domingo en la carretera de Madrid a Granada ${ }^{59}$, por el arquitecto escolar Don Luis Vázquez de Castro ${ }^{60}$.

58 Desde estas líneas queremos dedicar un emocionado recuerdo a la memoria de Manuel Millán López, arquitecto que entre otras realizaciones podemos contar con los primeros edificios del que fuera Colegio Universitario Santo Reino, hoy Universidad de Jaén.

59 En terrenos colindantes con los del Patronato "Santo Rostro", promovido por el Ministerio de Educación y Ciencia y redactado, en el mes de diciembre de 1957, según prototipo para zona cálida.

60 Edificio de doce aulas y 3.192 .950 pesetas de presupuesto, obra que fue adjudicada a la empresa constructora Trueba, S.A, con domicilio social en el número 47 de la madrileña calle de las Huertas, M-14. 
Tal edificio fue más tarde complementado con otro, igualmente de nueva planta, hasta componer con ambos el nuevo Colegiointernado de Santo Domingo, proyectado por el arquitecto Millán López.

Aún seguirán sucediéndose obras de reparación de cubier tas de aseos en el viejo y heroico caserón de la calle de los U ribe a lo largo de los años 60, en los que el farmacéutico don A ntonio Vázquez de la Torre, como presidente de la Diputación Provincial sustituiría al inolvidable psiquiatra don Juan Pedro Gutiérrez Higueras en dicho cargo ${ }^{61}$.

Conocemos que en el año 1969 se trabajaba en la instalación de cocinas y comedores del nuevo internado de Santo Domingo que aún en 1970 se trataba de terminar la restauración de la cubierta de la iglesia del antiguo Hospicio de Hombres, sin que conozcamos en qué momento se hiciera el traslado de funciones y ocupantes del antiguo al nuevo, pero tres años después, en 1973, se redactaba en la Diputación el proyecto de demolición del viejo edificio de Santo Domingo que afortunadamente no se llevó a cabo.

\section{Nuevas preocupaciones por el edificio}

Recuerdo con nitidez aquella soleada y apacible mañana de un domingo del año de 1974 cuando, tras pedir y obtener en la Diputación Provincial la llave de la puerta de entrada a aquel enorme edificio de Santo Domingo, penetré allí por primera vez en mi vida. En su hermoso claustro se podía oír el silencio, tras tantos años de existencia bulliciosa, ahora sólo interrumpido por el zureo de bandadas de palomas que descendían raudas a beber en su fuente central. Me acomodé, y tras unas cuatro horas de soledad, dibujé, en aquella tarea de plasmar para un libro los más bellos rincones de una ciudad cuya esencia se nos estaba yendo de las manos. $\mathrm{N}$ i siquiera se me presentó el duende que, al parecer, ahora se atreve a pasear por los inmensos depósitos de legajos del nuevo Archivo Provincial, destino último del edificio.

De igual manera recuerdo el día en que estuve contemplando desde las alturas de las inmediaciones del castillo de Santa Catalina la hermosa visión de los múltiple tejados que como un tapiz conformaban el casco antiguo de la ciudad, cuya textura de teja árabe se rompía violentamente en la cubierta de la iglesia de Santo Domingo, parcheada totalmente de fibrocemento, como si una enorme nave industrial hubiese encontrado allí acomodo. Resultaba aquel impacto visual y emotivo tan tremendo que me propuse intentar hacer algo para remediarlo.

La propuesta a la Dirección General de Bellas Artes de intervención en el edificio de Santo Domingo con la restauración de sus partes más dañadas fue prontamente atendida. $Y$ tras recibir de la Administración Central el correspondiente encargo, se iniciaron los trabajos para la redacción del necesario proyecto. Para ello, recopilamos una colección de planos del conjunto de la edificación, planos que habrían sido levantados con el estado general que presentaba en el año 1965, petición no exenta de recelo entre la corriente generalizada de enviar a la piqueta al viejo caserón. Tras largas jornadas de solitario deambular por todas las estancias vacías y abandonadas actualizando tales planos y tomando datos para mi propuesta de restauración, pudo concretarse en un proyecto que redacté el 7 de diciembre del año 1979.

Este proyecto se puede desglosar en las siguientes partes, ateniéndonos a lo descrito en su Memoria:

a) Reparación general de la cubierta de la iglesia (Fig.18).

61 El Doctor Gutiérrez Higueras fue el primer alcalde de Jaén en los años de la posguerra civil española, a quién se debe parte de la ejecución del proyecto de ensanche redactado por el arquitecto Berges Martínez, entre otras muchas obras. 
b) Recalzo y consolidación de uno de los muros que conforman el presbiterio de la iglesia, cuya ruina afectaba a una bóveda y al arco toral.

c) Restauración de las fachadas norte y este de las galerías altas del claustro del patio principal (Lams. 71-75)

d) Demolición de la tabiquería interior y de las particiones efectuadas en todas las naves componentes del edificio.

e) Pavimentación del patio principal.

Era manifiesto que, con tales limitadas actuaciones, en la totalidad tan compleja y extensa del edificio no se podía obtener la recuperación del inmueble, pero si el atender a lo más urgente y ponerlo en disposición de seguir actuando en fases sucesivas y en años próximos, ya que sin conocer a qué iba a poder ser destinado en el futuro, ni las necesidades parejas a cualquier uso, sí era fundamental iniciar, al menos, trabajos que pusiesen de manifiesto la preocupación e interés de su integración al patrimonio histórico, quedando al menos digno de poder ser visitado.

En relación con la cubierta de la iglesia, donde las formas de madera se habían sustituido por otras metálicas, en la última actuación en ella, se reforzaron sus perfiles para poder retejar sobre las placas de fibrocemento, y así ocultarlas ${ }^{62}$.

\section{Destino final del edificio de Santo Domingo}

Ya en el año 1980, la Subdirección General de Archivos recibiría de la Diputación Provincial el ofrecimiento del edificio de Santo Domingo, para dar en él cabida a todos los fondos que componían el Archivo Provincial, que ocupaba un interesante e insuficiente edificio de la calle Julio Ángel, que acabó por ser demolido como tantos otros de nuestra ciudad. Contenía un patio central porticado con pies derechos, columnas, zapatas y viguería, todo ello de madera.

En tal ofrecimiento de Santo D omingo, por la propia Subdirección General de Archivos, se acabó aceptando una superficie en planta baja de $2.904,21 \mathrm{~m}^{2}$, que excluía a la iglesia y dependencias anejas, sin que de nada valiesen argumentos para que el Ministerio de Cultura se hiciese cargo de la totalidad del inmueble. Aquella negativa el tiempo se encargaría de demostrar que fue, cuanto menos, errónea.

Fijada ya la parte del inmueble que iba a ser destinada a Archivo Histórico Provincial, la Subdirección nos encargaba el 11 de marzo de ese mismo año el proyecto de adaptación de Santo Domingo para el citado Archivo.

Como ya sabemos por todo cuanto anteriormente hemos descrito, el futuro Archivo Histórico iba a constar de una parte de indudable valor arquitectónico, formada por la fachada de la antigua iglesia de Santo D omingo, donde se aloja la portada manierista atribuida a A lonso Barba, y el patio central con claustro (Lam. 73), obra esta al parecer de Eufrasio López de Rojas (GALERA 1979: 51-52 y 207-211), mientras que el resto de la edificación, aparentemente en buen estado, se debía adaptar con el fin de dar cabida dentro de sus volúmenes a todo el complejo y amplio programa constitutivo de un moderno archivo documental, lo que en líneas generales precisaba mayor superficie a construir que la disponible, ambas condiciones, la de valor arquitectónico y la de insuficiente capacidad, fueron las que se manejaron a la hora de plantear el proyecto de adaptación.

Respecto a lo primero, quiero aportar aquí una documentación gráfica inédita, particular, que pueda ser empleada por futuros estudiosos. Incluye fotografías de muros aparecidos al levantar los suelos (Lams. 74-81), que los arqueólogos deberán relacionar en el futuro

62 Tales obras salieron a subasta pública, siendo adjudicadas por el Ministerio de Cultura el 23 de septiembre de 1980 a Agroman, Empresa Constructora S.A., en la cantidad de 7.749 .566 pesetas, comenzadas dos meses más tarde y concluidas en mayo de 1981. 
con los aparecidos en el Palacio de Los U ribe y solares anejos. Así mismo documentación respecto a los muros de tapial con que fue levantado buena parte del edificio original (Lam. 82), y los trabajos de restauración de la sillería (Lams.: 83-87).

Pero fue la segunda premisa la que desde el principio constituía el verdadero reto del trabajo. Se trataba de encontrar, sin modificar ni ampliar exteriormente los volúmenes constitutivos de la edificación, ni por excavación del subsuelo, ni por aumento de la altura de ella, la manera de conseguir el máximo de metros cuadrados de superficie destinados al montaje de armarios compactos y anaqueles para contener legajos documentales.

A su vez, esta documentación representaba una importante carga, peso que los forjados de piso existentes no estaban capacitados para soportar. De igual manera, era necesidad primordial el desdoblamiento de accesos y circulaciones, la mayor capacidad posible de superficie destinada a depósitos de documentos, sus condiciones de acceso a ellos y de conservación que se trataba de ocultar con tales zócalos y el no poder rebasar los límites físicos de la edificación existente.

A. En líneas generales, el PRO GRAMA DE NECESIDADES dado se distribuyó de la siguiente manera:

Planta a nivel $+0,00$. Entrada general del edificio por la puerta bajo la portada de A lonso Barba, que se abre en la calle de Santo D omingo, puerta que está en comunicación con un amplio vestíbulo desde donde se desciende al claustro y patio central mediante una escalera abierta en su extremo izquierdo (Figs. 21-23; Lam. 88), habiéndose previsto un futuro acceso desde su punto central a la iglesia de Santo Domingo. A su vez, desde el claustro de dicho patio central se accede a una sala de conferencias (Lam. 89) e igualmente al control de entrada de la sala de investigadores, fotocopiadoras, secretaría y aseos generales. Una entrada desde la secretaría permite el acceso a un vestíbulo cortafuegos y a un primer depósito de legajos.
Mediante un porche exterior cubierto se relaciona el vestíbulo principal y caja de escalera general con la dependencia de descarga y recepción del material de documentación, dependencia que a su vez se comunica con un segundo vestíbulo cortafuegos donde se dispone el cuarto de maquinaria de uno de los montacargas. D os patios ajardinados además del patio central aseguran luz natural a todas las dependencias del edificio que la precisan (Lam. 90-91).

Planta a nivel $+4,30$. Está dedicada íntegramente a depósito de legajos, a los que se accede desde ambos vestíbulos cortafuegos. Es una entreplanta añadida al edificio primitivo (Fig. 24; Lam. 92).

Planta a nivel $+6,30,0$ planta alta del edificio primitivo, a la que se accede por la escalera principal, de nueva planta. Consta de cinco despachos de dirección y trabajo y un grupo de aseos para ambos sexos. En la galería sobre el claustro, se ha montado sala de clasificación y fichado, así como el cuarto de revelado, de microfilmación y de restauración, complementado todo ello con un cuarto de toma y vertido de agua y una habitación-almacén. El resto de la planta se destina a depósitos de legajos, con los dos vestíbulos cortafuegos (Fig. 25; Lam. 93).

Planta a nivel $+9,30$. Se trata de otra entreplanta añadida al edificio dentro del volumen primitivo, destinada toda ella a depósitos de legajos, con los dos vestíbulos cortafuegos (Fig. 26).

Planta a nivel $+11,80$, 0 antigua planta de cámaras del edificio, destinada a depósitos de legajos alrededor de uno de los vestíbulos cortafuegos (Fig. 27).

\section{B. SUPERFICIE Y VOLUMEN DE EDIFICACIÓN}

Lo resumimos en el siguiente cuadro:

\begin{tabular}{|c|c|c|}
\hline Plantas & $\mathrm{m}^{2}$ construidos & Volumen edificio \\
\hline$+0,00 \mathrm{y}+1,20$ & $1.668,47$ & $5.840,00$ \\
\hline Claustro y Jardines & $1.235,74$ & --- \\
\hline$+4,30$ & 868,25 & $1.910,10$ \\
\hline$+6,80$ & $1.721,00$ & $5.163,00$ \\
\hline$+9,30$ & 871,33 & $1.917,00$ \\
\hline$+11,80$ & 725,00 & $1.595,00$ \\
\hline
\end{tabular}




\section{COSTE DE LAS OBRAS}

Dado que el edificio se amuebló con posterioridad damos el precio de la obra que fue el siguiente:

Proyecto primitivo

89.340 .366 pts.

Pr. adicional y Reformado

19.438 .298 pts.

Total presupuesto contrata

108.778 .664 pts.

\section{CAPACIDAD DOCUMENTAL}

La expresamos en metros cuadrados de superficie útil de depósitos de legajos, así como en metros lineales de anaqueles que pueden ser dispuestos en el interior de ellos, teniendo en cuenta que se han contabilizado cinco entrepaños en anaqueles de 2.00 metros de altura por ambos lados del mueble, que se suponen con una anchura total de 0,75 metros y separados otros 0,75 entre sí las siguientes capacidades:

\begin{tabular}{|l|c|r|}
\hline Planta & $\mathrm{m}^{2}$ Superficie útil & m. A naquel \\
\hline$+0,00 \mathrm{y}+1,20$ & 299,34 & $1.525,00$ \\
\hline$+4,30$ & 525,25 & $2.485,00$ \\
\hline$+6,80$ & 636,75 & $3.233,00$ \\
\hline$+9,30$ & 563,31 & $3.058,00$ \\
\hline$+11,80$ & 491,28 & $2.406,00$ \\
\hline TOTAL & $2.515,93$ & $12.707,00$ \\
\hline
\end{tabular}

\section{E. FECHAS DE PROYECTO Y TERMINACIÓN}

La fecha de redacción del proyecto fue de abril de 1981 y la de terminación de la obra la de mayo de 1985.

\section{Otros datos significativos}

En relación con las condiciones óptimas de conservación de los legajos en los depósitos, tales condiciones de temperatura y humedad dadas en el programa inicial sólo se podían obtener mediante la climatización de las salas, lo cual a su vez determinaba un gran gasto mensual de consumo de combustible líquido (gasóleo) o electricidad, fuera de las posibilidades de financiación a través de la dotación anual adjudicada a estos Centros. Hecha la correspondiente consulta a la Subdirección de Archivos, se optó como solución un sistema de ventilación mediante renovación del aire interior, para evitar humedades por condensación, 0 de acumulación de aire caliente en verano en el interior de los depósitos de legajos.

Estas áreas también han sido dotadas de detectores de humos, y de alarma sonora en cada planta, centralizado todo ello en la conserjería.

En cuanto a la climatización del resto del edificio, se ha dotado de esto a la sala de lectura de investigadores, conserjería y secretaría, así como a los cinco despachos situados en la planta principal.

A las salas de exposiciones y conferencias se les ha dotado de radiadores eléctricos ${ }^{63}$.

\section{CONCLUSIÓN}

Los investigadores de hoy día estudian la evolución de la ciudad y la historia de sus edificios, partiendo no solamente de la documentación de archivo o de los restos materiales que nos ofrecen las excavaciones y que interpretan los arqueólogos. Lejos de ello el equilibrio entre los documentos y los restos materiales, es fundamental. La documentación o material de archivo y los yacimientos arqueológicos -que por sí mismos generan, preceptivos informes de las excavaciones, que resulta ser material de archivo que es imprescindible consultar-, deben ir inseparablemente unidos como se está demostrando en los últimos años, gracias a la visión de algunos historiadores-arqueólogos 0

63 Memoria del proyecto de adaptación del antiguo Convento de Santo Domingo para Archivo Histórico Provincial. Firmado en Jaén, en Junio de 1985 por el Dr. Arquitecto Luis Berges Roldán. 
arqueólogos-historiadores, y que tantos y tan buenos resultados histo rio gráficos están dando.

El fin de nuestro trabajo es contribuir a hacer la historia siempre inacabada de Jaén, y despertar con ello la conciencia de conservación de nuestro patrimonio, estimulada en algunos sectores y dormida aún, en otros, motivos a los que habría que unir el tratar de mostrar aspectos de nuestra ciudad, y de nuestros espacios y edificios singulares en los que, otros profesionales tuvieron ocasión de intervenir. Conocedores, por ello, de la naturaleza arquitectónica, de estos elementos esenciales de nuestro patrimonio, ahora pueden considerarse los datos aportados por ellos necesarios para contribuir a un conocimiento más amplio de la ciudad de Jaén.

Los tres espacios, Fuente de la Magdalena, palacio de los Uribe y convento de Santo Domingo, han constituido tres enlazadas ocasiones donde los datos so bre las intervenciones a las que aludíamos han dado lugar a este trabajo.

\section{Fuentes documentales:}

\section{A.C .:Actas capitulares}

C.M.E: Catastro Marqués de la Ensenada.

Expedientes de obras en edificios de la Beneficencia Provincial. Santo Domingo, Hospicio de hombres.

\section{Archivos consultados}

A.H.P.):Archivo Histórico Provincial de Jaén.

A.H.D.J:Archivo de la Diputación Provincial de Jaén.

Archivo privado de Don Luis Berges Roldán (fotografías y planos)

\section{BIBLIOGRAFÍA}

AGUIRRE SÁDABA, Fo. J. (1982): "El Jaén islámico". En $H$ istoria de Jaén. Jaén.

AGU IRRE, Fo J.; JIMÉN EZ, Mạ. C . (1979): Introducción al Jaén islámico. Jaén.
BELLÓ N, JP.; RUEDA, C. (2001): “De foro a vertedero en el Decumanus Máximus de Aurg. Resultados de la intervención arqueológica de urgencia en la calle Sto. D omingo 19 a 25 de Jaén". Arqueologáa yTeritorio Medieval, Vol. 8. Jaén.

BELLÓ N , JP.; MO N TILLA, I.; LISA LDE, R.; ALC ALÁ, Fā; BA RBA ,V. (1997): Informe sobre la intervención arqueológica de urgencia en la calle Sto. Domingo números 19 a 25 de Jaén. Archivo de la Delegación Provincial de Cultura de Jaén, Inédito. Jaén.

BERGES RO LDÁN . L. (1979): Memoria histórica del proyecto de restauración del antiguo Convento de Santo Domingo. Jaén, Inédito.

BERGES RO DÁN , L. (1985): Memoria del proyecto de adaptación del antiguo Convento de Santo Domingo para Archivo Histórico Provincial. Inédito.

BERGES RO LDÁN ,L. (2007): "La iglesia de La Magdalena. Jaén. De mezquita islámica a templo cristiano". Arqueología y Territorio M edieval,Vol. 14. Jaén.

C AMPO S,T. (2003): "A rqueología, arquitectura e historia en el Archivo Histórico Provincial de Jaén". Arqueología de la Arquitectura, vol. 2. Jaén.

CAMPO S, T;; VISED 0, A . (2002): “Inter vención arqueológica de urgencia en el Archivo Histórico Provincial de Jaén." Anuario Arqueológico de Andalucía. Sevilla.

CAÑ ADA Q UESADA, R. (2006): “Linajes N obles en la ciudad de Jaén. Los U ribe". Revista Hidalguias. Instituto Salazar Castro. Boletín n 316/17. Mayo-Agosto. CESIC. Madrid, pp. 349-384.

CASUSO QUESADA, R. A. (1998) A rquitectura del siglo XIX en Jaén. Diputación provincial de Jaén, I.E.G. Jaén.

CATALÁ SANZ, J.A. (1915): Rentas y patrimonios de la nobleza Valenciana en el S. XVII. Madrid, 1915.

CAZABÁN LAGUNA,A. (1913): "Romancero de Jaén". Don Lope de Sosa. Año 1913.

CAZABÁN LAGUNA,A. (1916): "La casa de los U ribe". Don Lope de Sosa.

CAZABÁN LAGUnA, A. (1916): "Convento de Santa Catalina. Frailes Dominicos, 1382". Don Lope de Sosa.

CAZABÁN LAGUN A,A.(1916):"La fundación Peñalosa”. Don Lope de Sosa.

CAZABÁN LAGUNA,A. (1916):"Hoy como ayer". Don Lope de Sosa.

CAZABÁN LAGUNA, A. (1920): "Jaén y el Cardenal Cisneros". Don Lope de Sosa.

CAZABÁN LAGUNA,A. (1923): “N otas e ilustraciones a un texto del Deán Mazas". Don Lope de Sosa.

CAZABÁN LAGUNA.A. (1923): "Industrias de telas en los Hospicios de Jaén". Don Lope de Sosa. 
CAZABÁN LAGUN A.A. (1923):"El catálogo y la colección de escudos. Escudo en la puerta de la casa de la calle de los Uribe no1", Don Lope de Sosa.

C AZABÁN ,A. (1923): "La iglesia de La Magdalena". Don Lope de Sosa.

CAZABÁN LAGUNA,A. (1923): “Escudo sobre la portada de la casa de los U ribe". Don Lope de Sosa.

CAZABÁN LAGUNA,A. (1924): "A sunto ruina portada Alonso Barba". Don Lope de Sosa.

CAZABÁN LAGUNA A.(1924):"Sobre el escudo de don Juan Cerezo". Don Lope de Sosa.

CAZABÁN LAGUNA.A. (1926): “Incoación expediente monumento de la fachada de Alonso Barba y patio principal". Don Lope de Sosa.

CAZABÁN , A. (1930): “La portada de La Magdalena”. Don Lope de Sosa.

CHAMORRO, J. Guía artística monumental de la ciudad de Jaén. Jaén, 1971.

DIEZ BED MAR, Ma C . (1999): El raudal de La Magdalena y el crecimiento urbano de Jaén. Jaén.

D ÍEZ BEDMAR, Ma C. Urbanismo y Sociedad en la Jaén Bajomedieval. Jaén, 2008.

ESTEBAN MÁRFIL, A. (2003): Informe Arqueológico de Urgencia realizado en el solar número 10 en de la Calle Santo Domingo de Jaén. Delegación de Cultura. Jaén.

GALERA, P.; RUIZ CALVEN TE, M. Corpus documental para la Historia del Arte de Jaén. Jaén, 2006.

GALERA AN DREU.P.A. (1979): Arquitectura de los s. XVII y XVIII en Jaén. Granada.

GARC ÍA SAN CHEZ,A. La organización de la Beneficencia en la provincia de Jaén en el siglo XIX: 1822-1852. Jaén, 2007

GO NZÁLEZ RO MÁN, C. y MAN GAS MAN JARRÉS, J. (1991): Corpus de Inscripciones Latinas de Andalucía. Vol. Ill. JAÉN. Tomo I. Sevilla.

HUERGA, A. Los Dominicos en Andalucía. Madrid, 1992.

LÓ PEZ PÉREZ, M. El viejo Jaén. Jaén, 2003.

MARTÍN EZ DE MAZAS, J. Retrato al natural de la ciudad y término de Jaén. (Ed. facsímil de la de Jaén de 1794). Barcelona, 1978.

O RTEGA SAGRISTA, R. (1987): “Estancia de los Reyes Católicos y de Cristóbal Colón en Jaén en el año 1489". Conferencia pronunciada en el I.E.G. con motivo de la inauguración oficial del curso 1985-1986, en Escenas y costumbres de Jaén. Salamanca.
O RTEGA Y SAG RISTA, R. "La extinguida Universidad de Santa Catalina Mártir, de la ciudad de Jaén". B.I.E.G. No 54. Jaén, 1967.

RAM ÍREZ DE JUAN, M. E. (2003): Las propiedades de los Conventos de Jaén, a través del Catastro de Ensenada. Jaén.

RAM ÍREZ DE JUAN, M. E. (2006): “A portaciones documentales para el estudio de los conventos de dominicas de Jaén: Santa María de los Ángeles y la Purísima Concepción". Gienium I, Jaén, pp.

SALVATIERRA, V. (1993): "Jaén en los siglos XIII y XIV. La formación de la ciudad cristiana". Revista del Centro de Estudios Históricos de Granada y su Reino. Vol. 7, Jaén, 1993.

SALVATIERRA, V. (2007): Discurso de ingreso don Vicente Salvatierra Cuenca en el Instituto de Estudios Gienneneses. I.E.G ., Jaén.

SALVATIERRA,V.; ALCÁZAR, E. "La distribución del agua en Jaén durante el periodo islámico" en Formas de habitar e alimentaçao na Idade Media. A rqueología Medieval, vol. 4. Mértola, 1996.

SALVATIERRA ,V.; PÉREZ, Maㅡ _;C A STILLO,J.L.;ALCÁZAR, E.; CAN O, J. "Formación y evolución de una ciudad islámica. Jaén" IV Congreso de arqueología medieval española. Sociedades en transición. Vol. II. A licante, 1993.

SERRAN 0 PEÑ A, J.L. Aurgi. Estudio del municipio romano desde la arqueología urbana de Jaén 1985-1995. Jaén, 2004

TO RALY FERN AN DEZ DE PEÑ ARA N DA, E. M enorial de la casa y solar de los Messía, notas y apéndices al manuscrito que dejara D. Fernado Messía. Instituto de Estudios Giennenses. Jaén, 1958.

TRILLO DE LEIVA, J. L. Sevilla: la fragmentación de la manzana. Sevilla, 1992

URIBE-SA LAZAR Y FÁBREGAS, A. (2004): Los Uribe Salazar y su Historia (Edición privada). Barcelona.

VAQUERO PIÑERO, M. La Rentas y las Casas. EI Patrimonio Inmobiliario de Roma entre los siglos XV y XVIII de Santiago de los Españoles. L'erma di Bretchneider. C .S.I.C. Roma, 1999.

V.V.A.A. Catálogo Monumental de la Ciudad de Jaén. Jaén, 1985.

XIMEN EZ PATO N, B. (1983): Historia de la antigua y continuada nobleza de la ciudad de Jaén. (Ed. facsimil de la de1628). Jaén. 


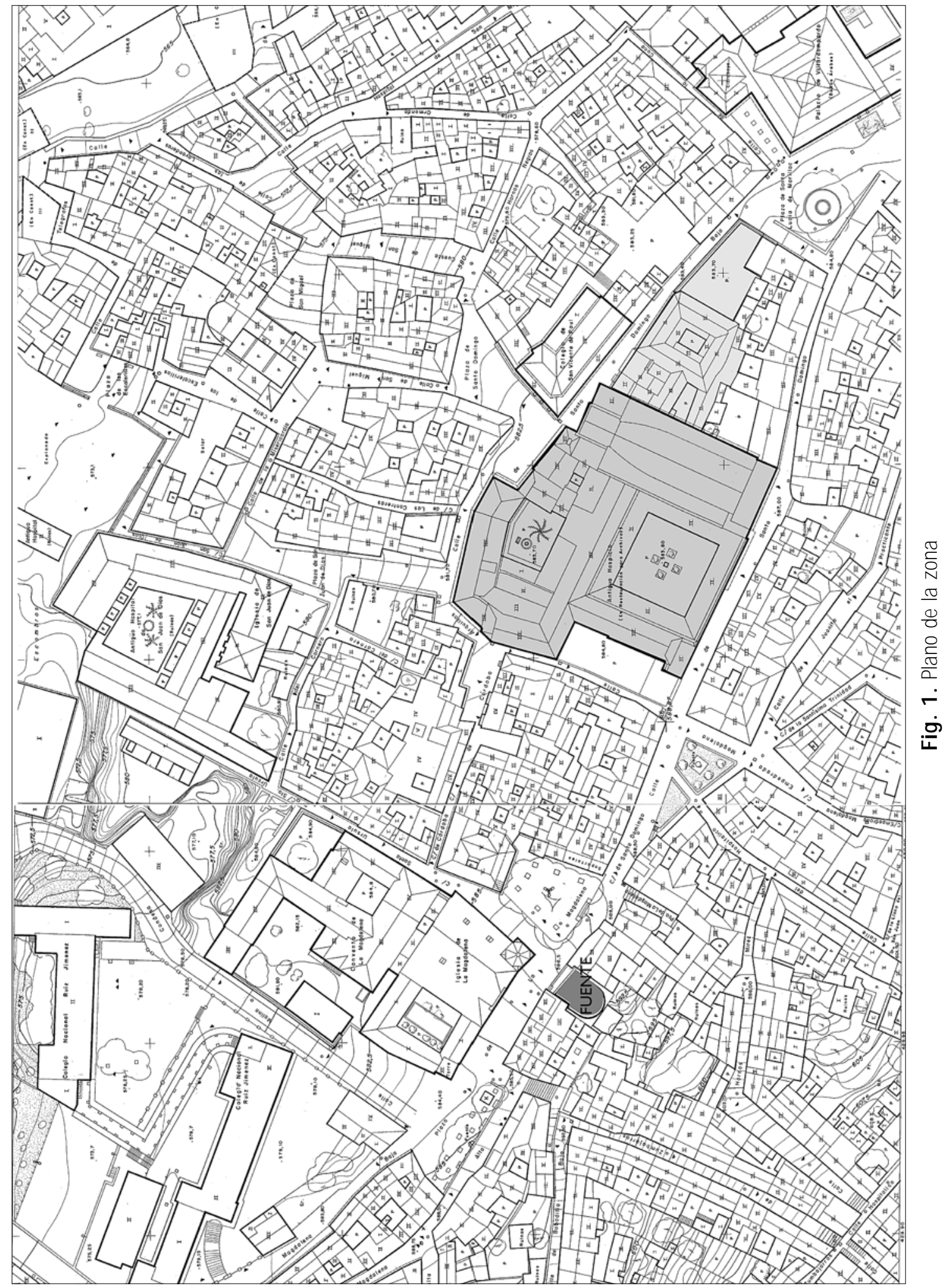




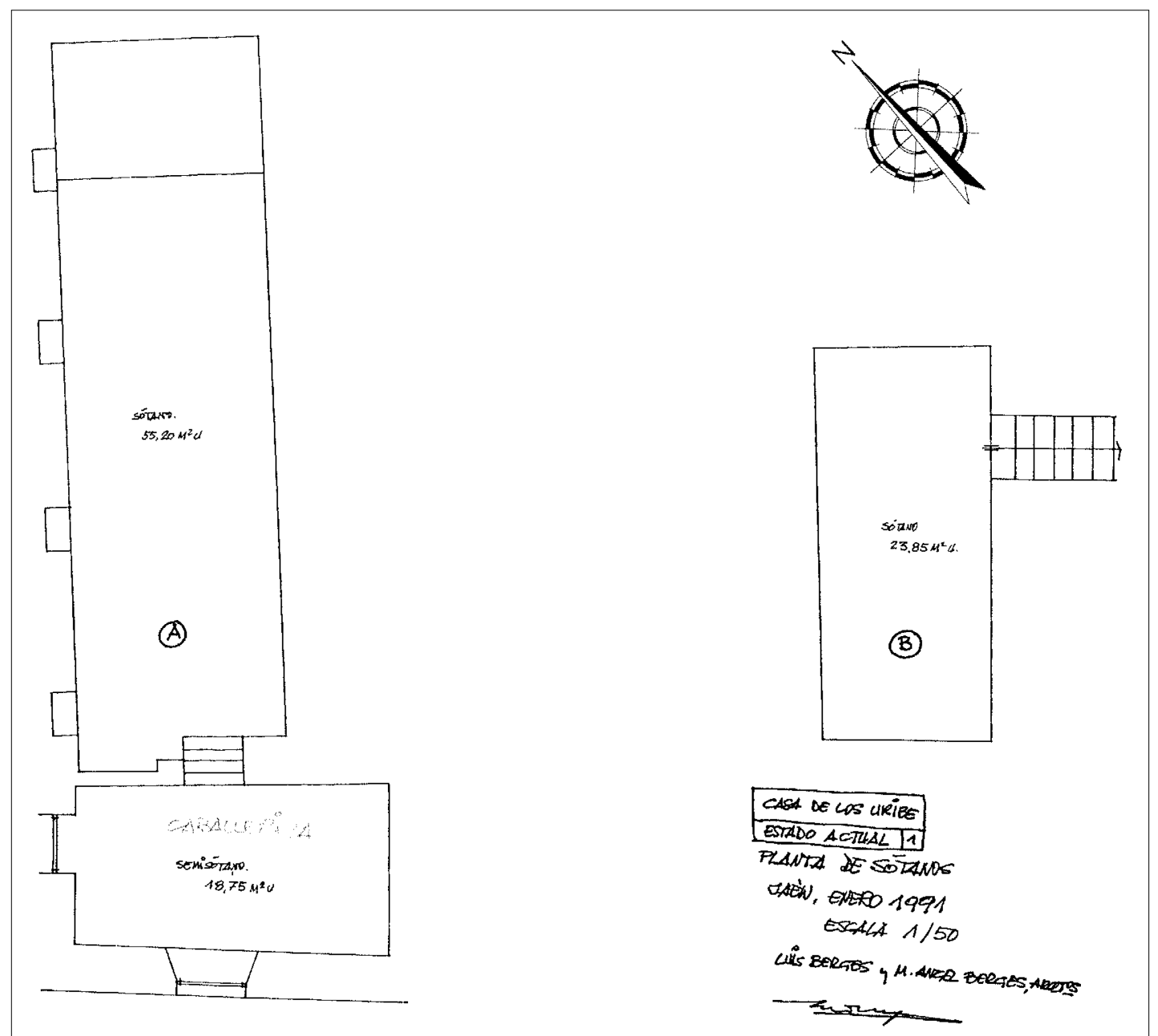

Fig. 2. Palacio de Los Uribe. Planta Bodegas

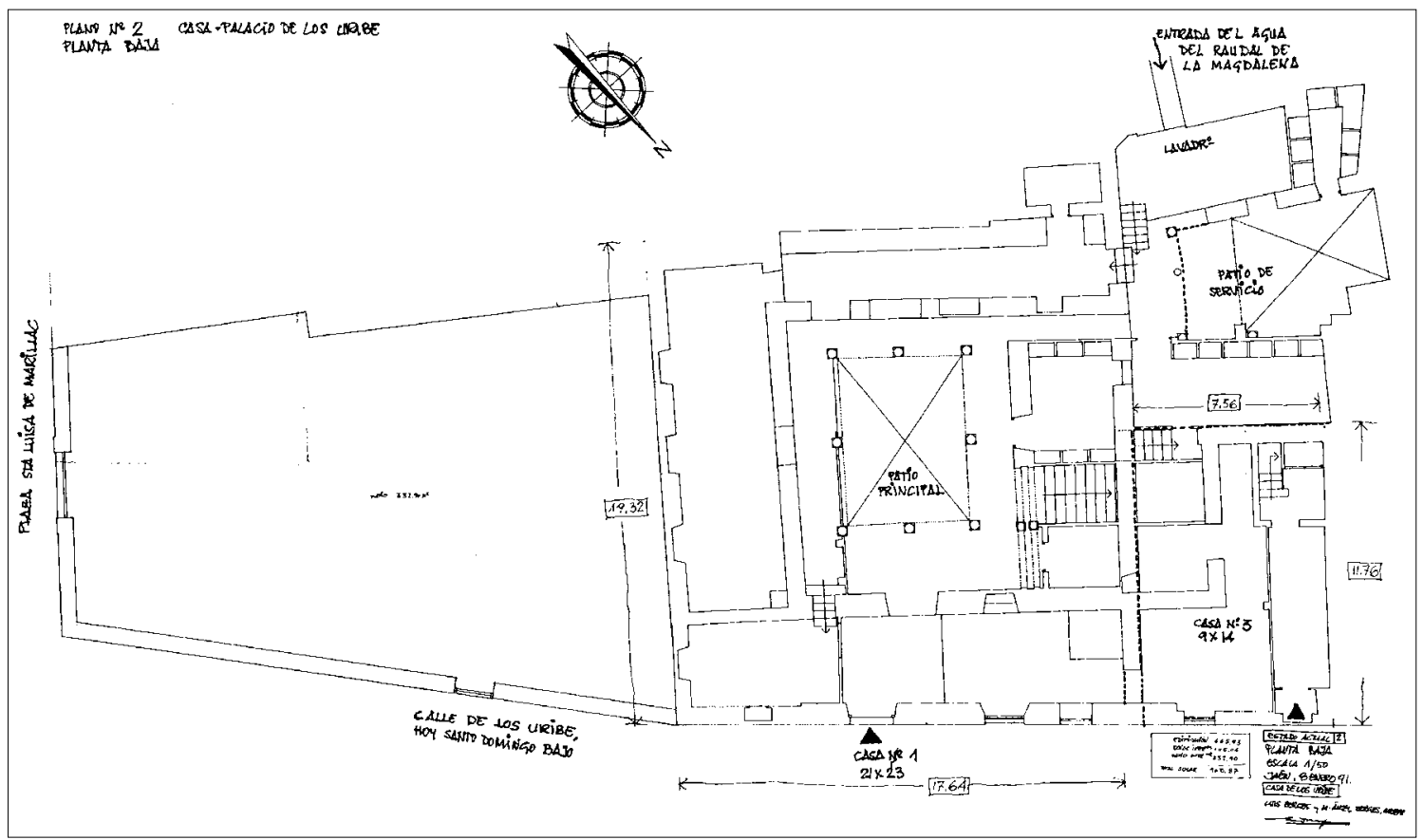

Fig. 3. Palacio de Los Uribe. Planta Baja 


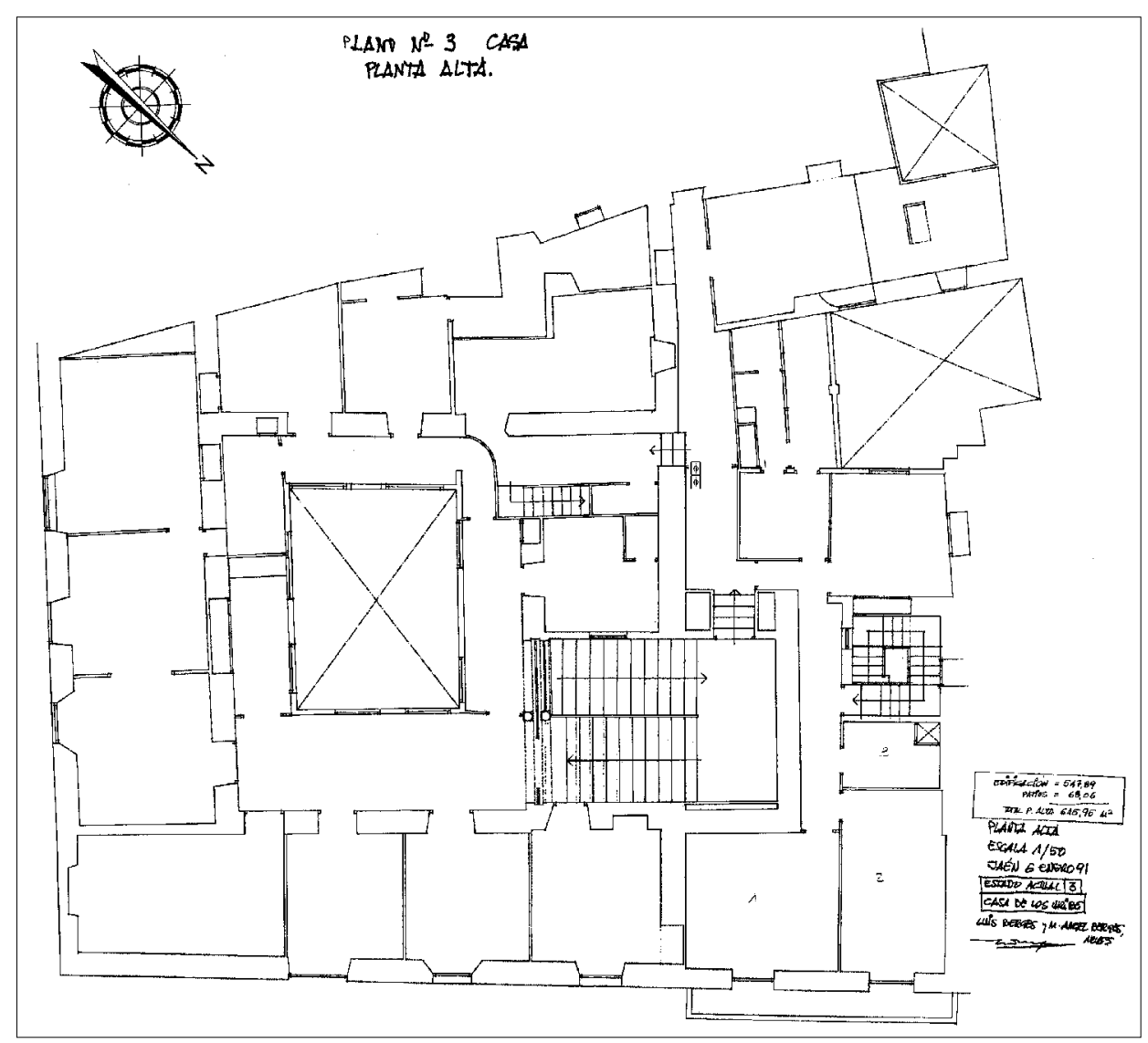

Fig. 4. Palacio de Los Uribe.

Planta Alta

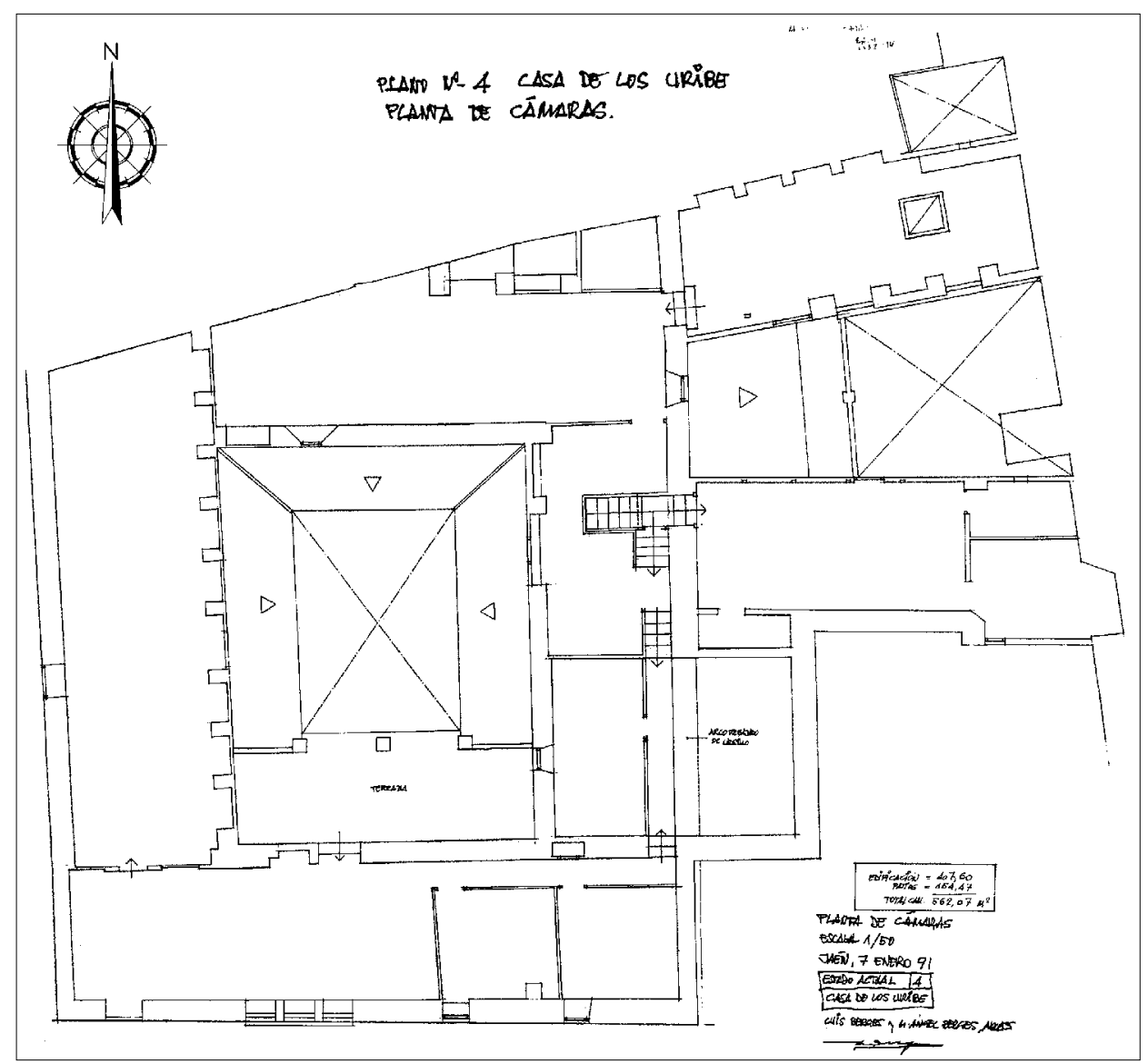

Fig. 5. Palacio de Los U ribe. Planta de Cámaras 


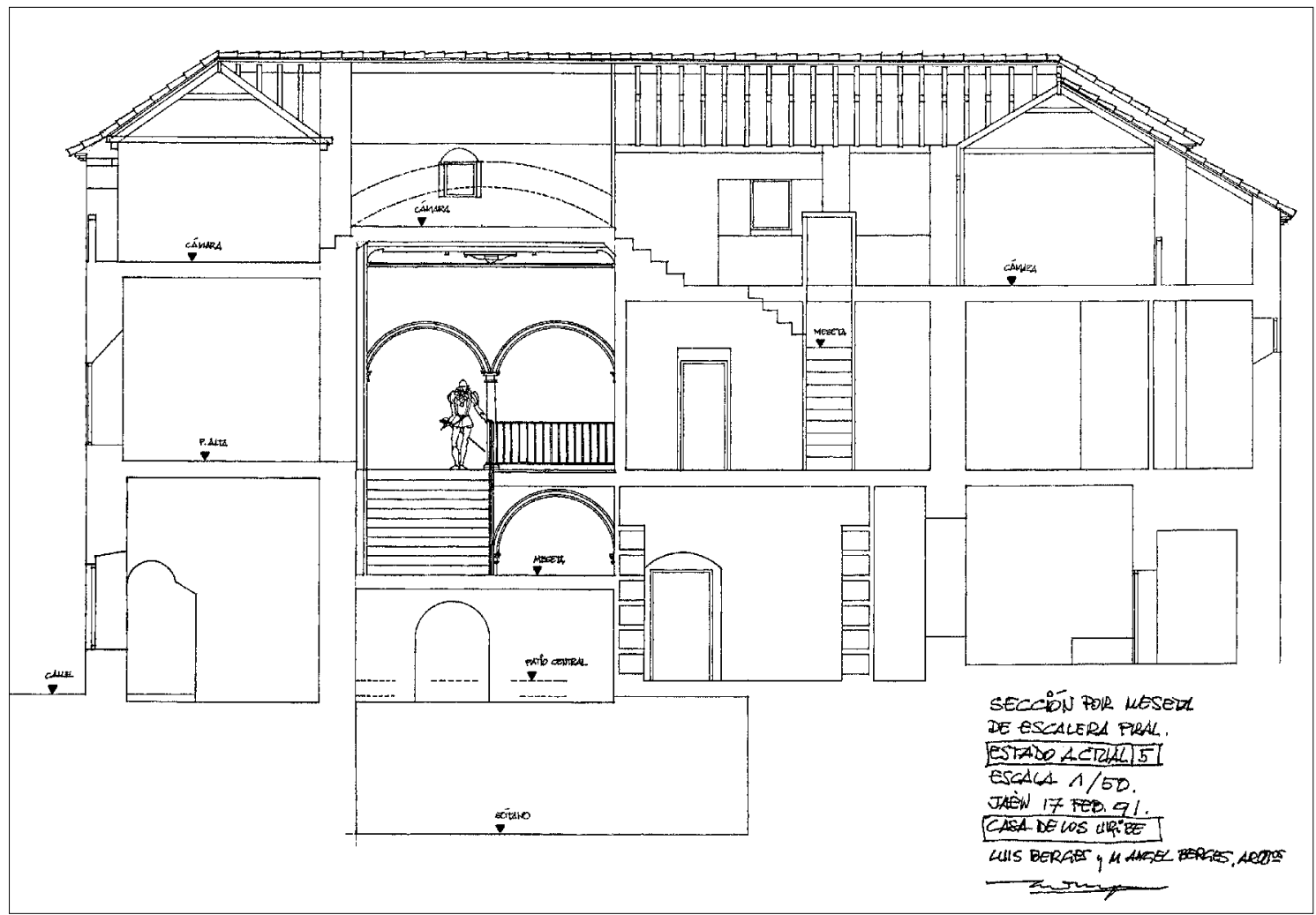

Fig. 6. Palacio de Los Uribe. Sección por la meseta de la escalera

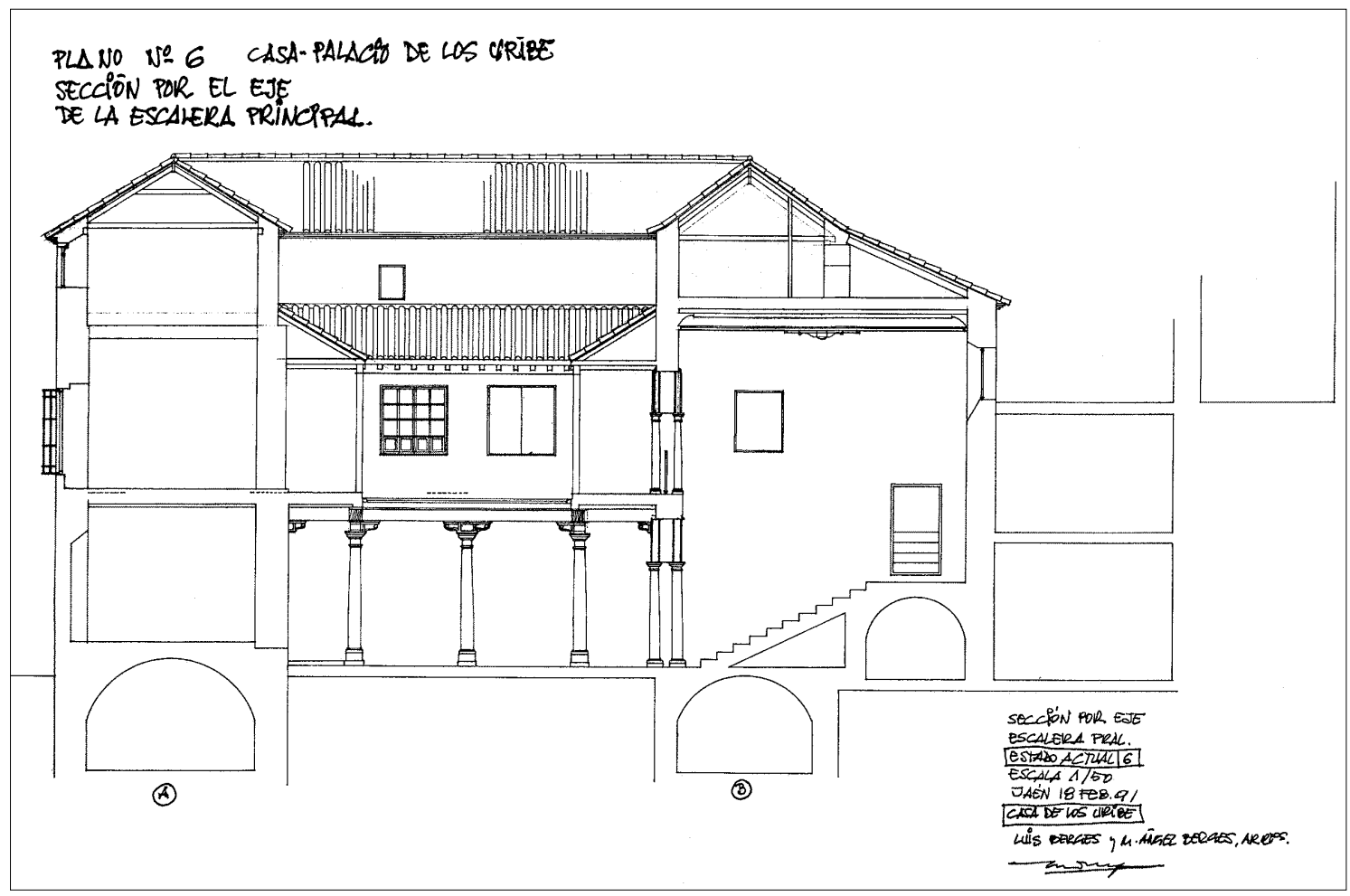

Fig. 7. Palacio de Los Uribe. Sección por el eje de la escalera principal 


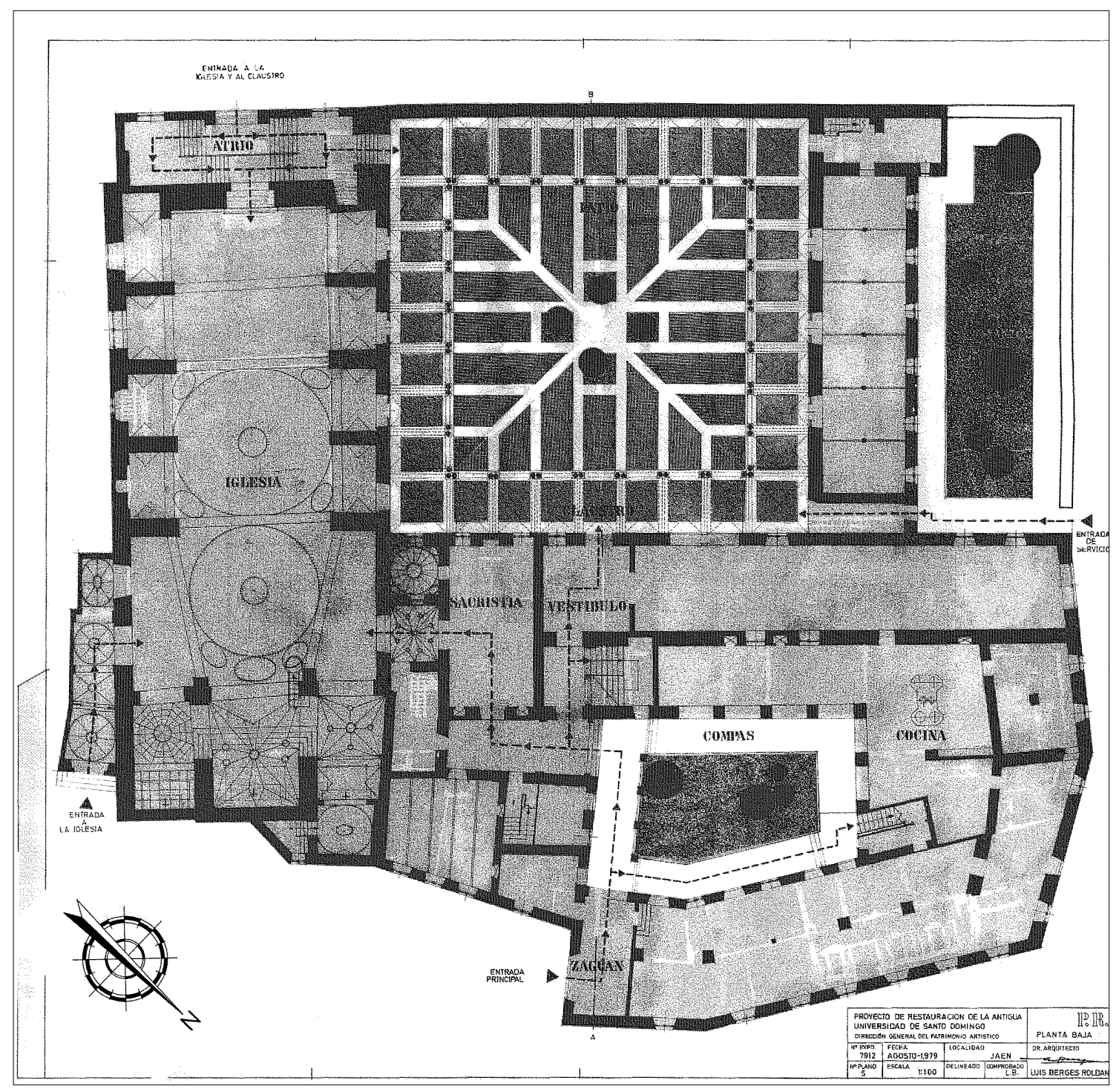

Fig. 8. Antigua Universidad de Sto. Domingo 1965. Planta baja

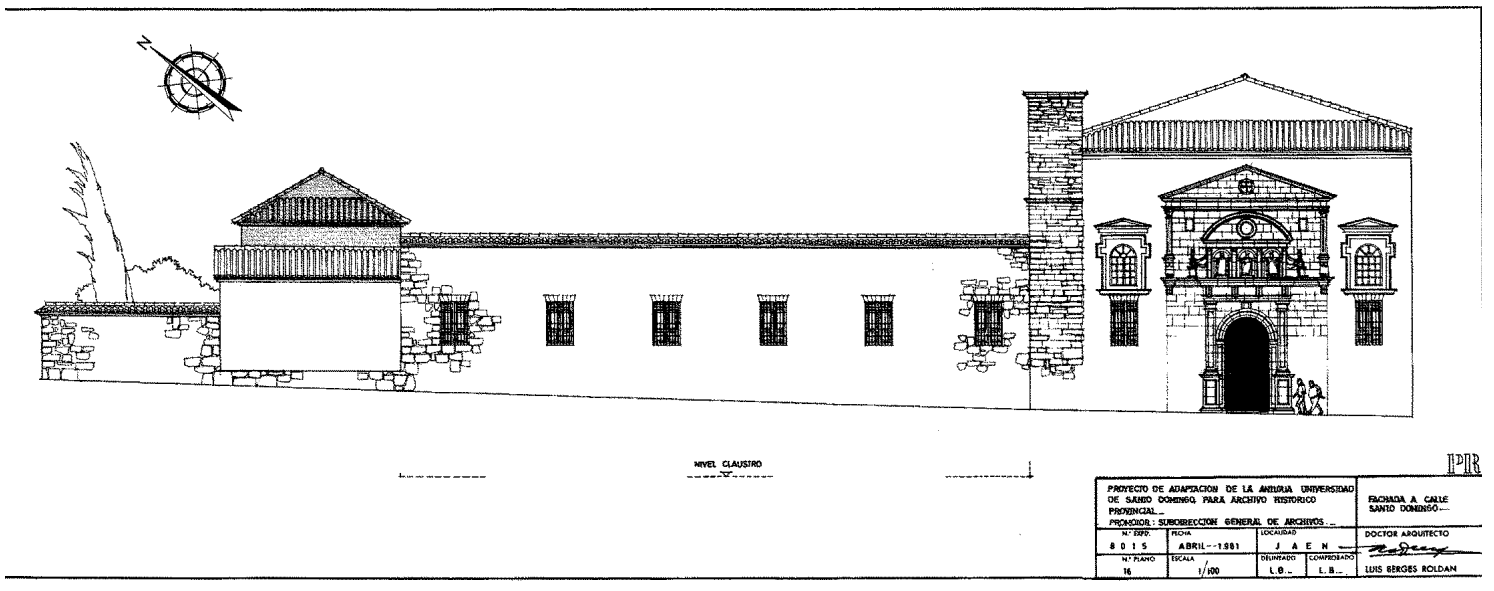

Fig. 9. Archivo Histórico Fachada C/ Sto. Domingo 


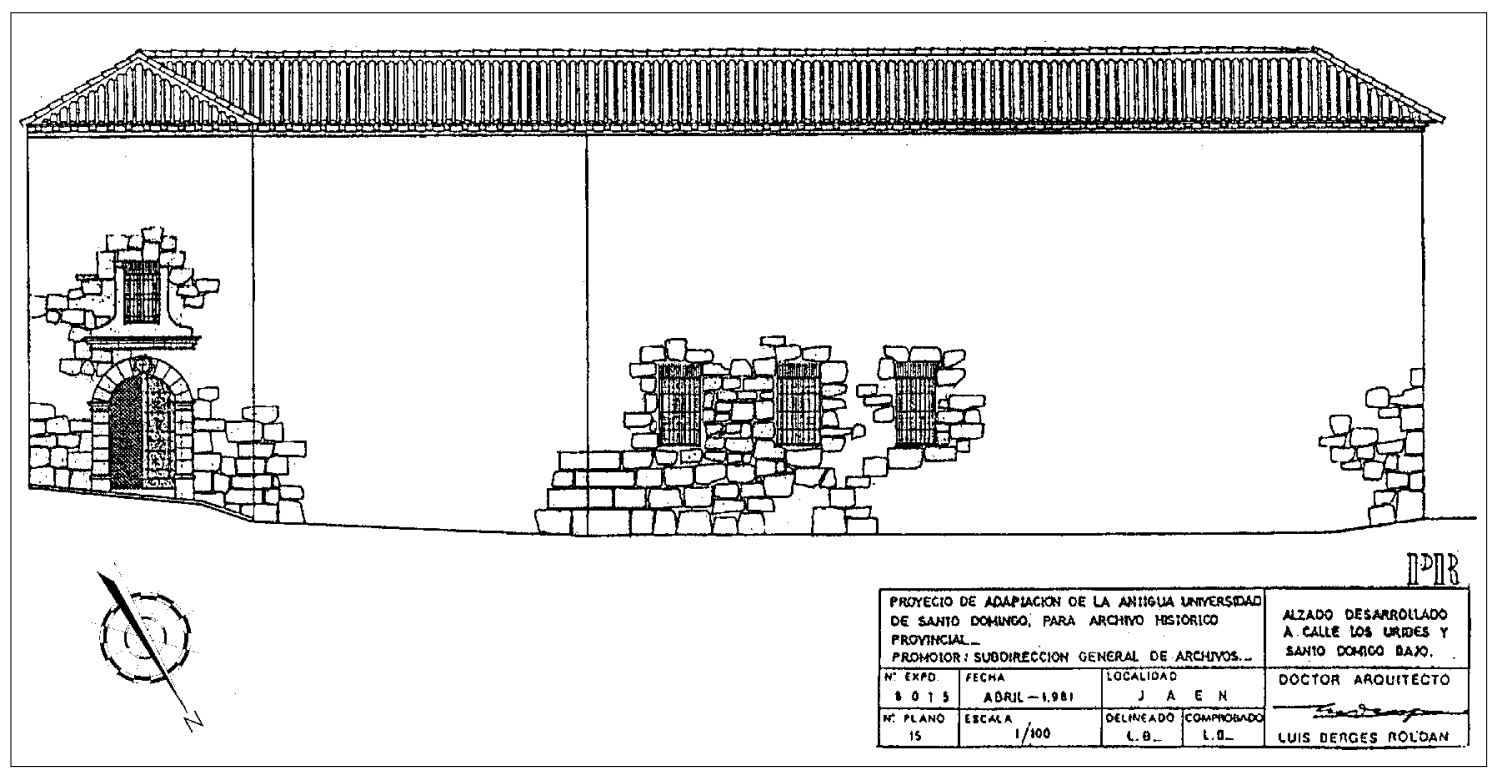

Fig. 10. Archivo Histórico Fachada C/ Sto. Domingo Bajo

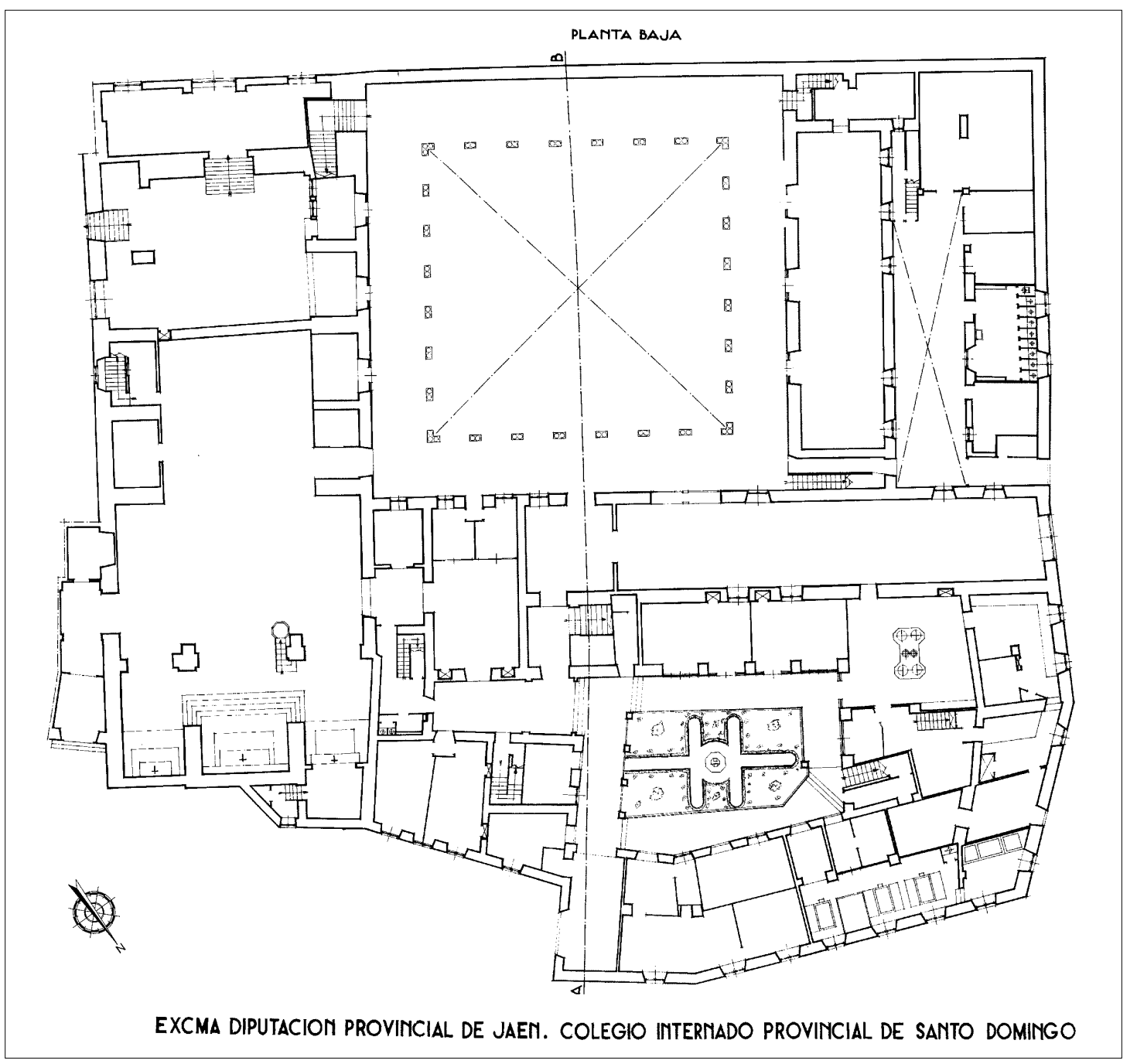

Fig. 11. Plano Hospicio de Hombres 1965. Planta Baja 


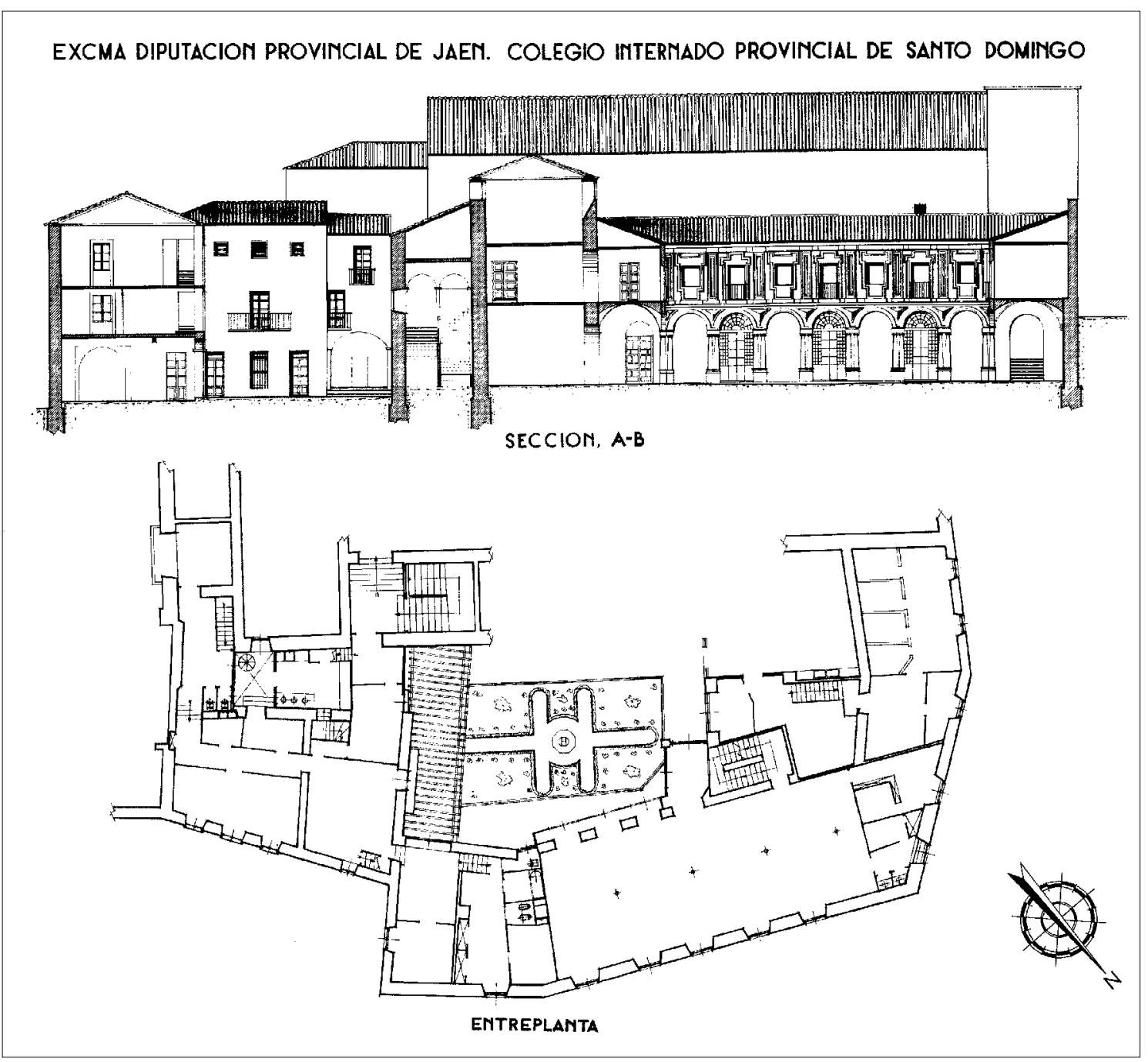

Fig. 12. Plano Hospicio de Hombres 1965. Entreplanta y Sección A-B 


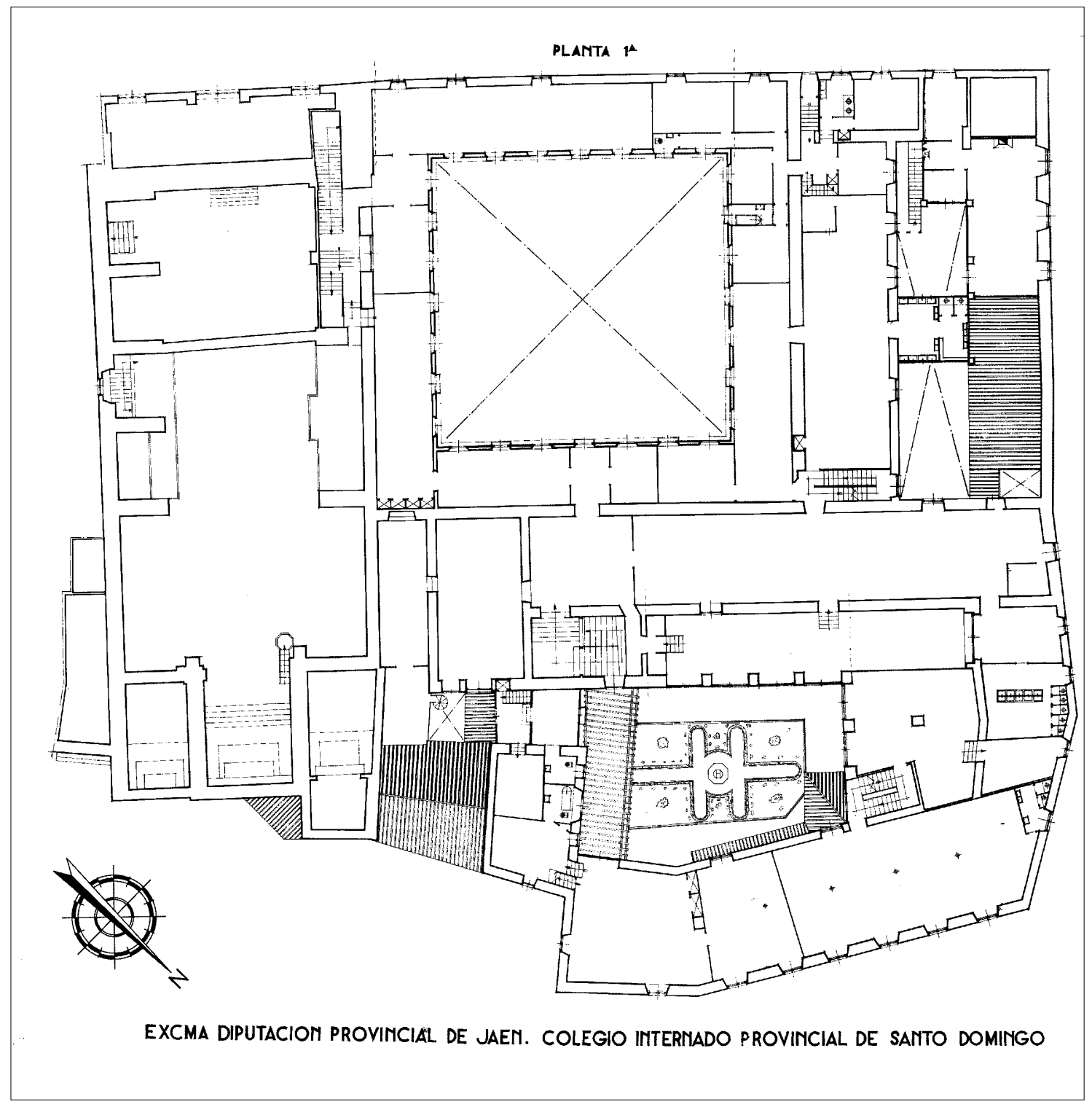

Fig. 13. Plano Hospicio de Hombres 1965. Planta primera 


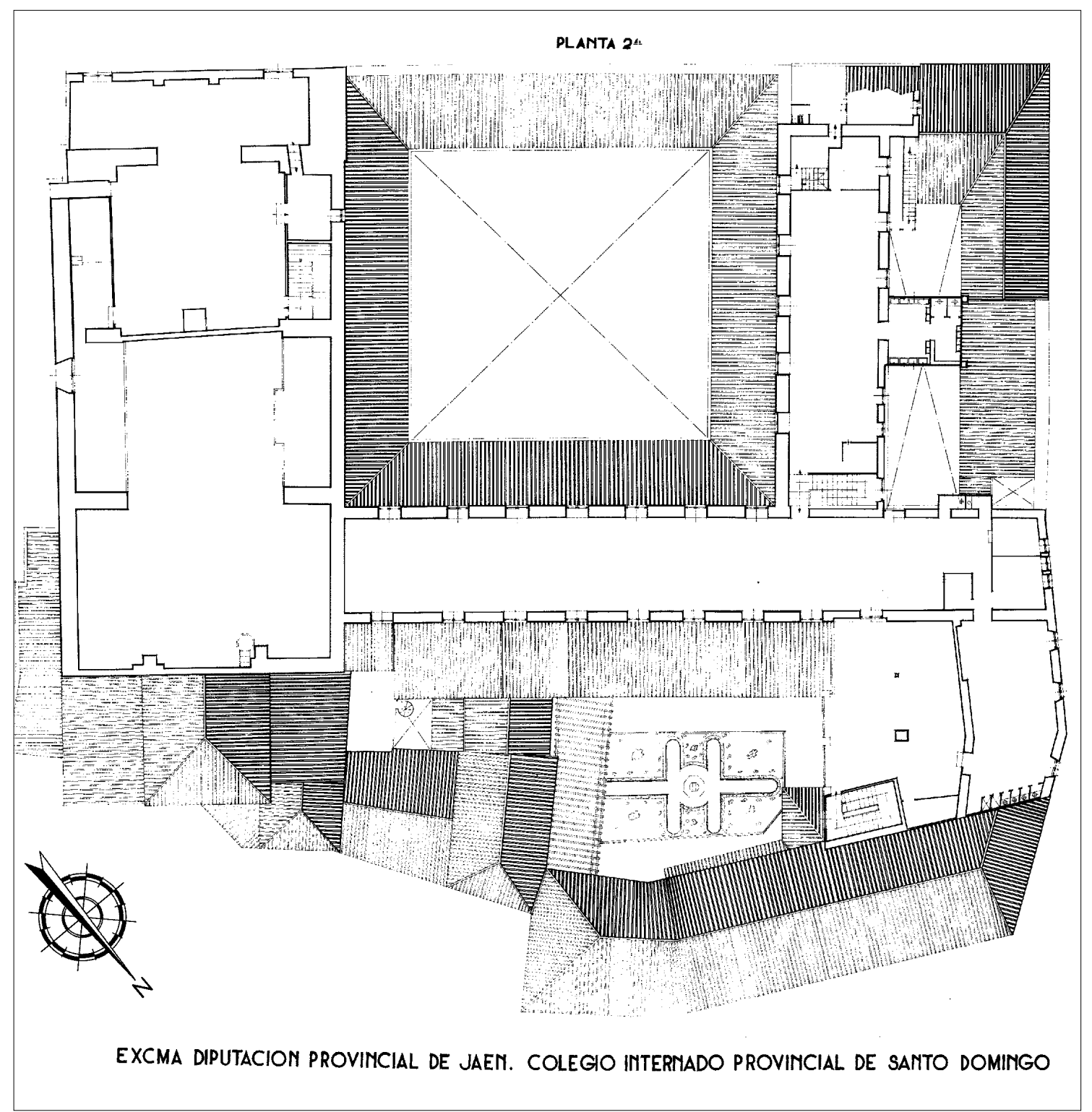

Fig. 14. Plano Hospicio de Hombres 1965. Planta segunda 


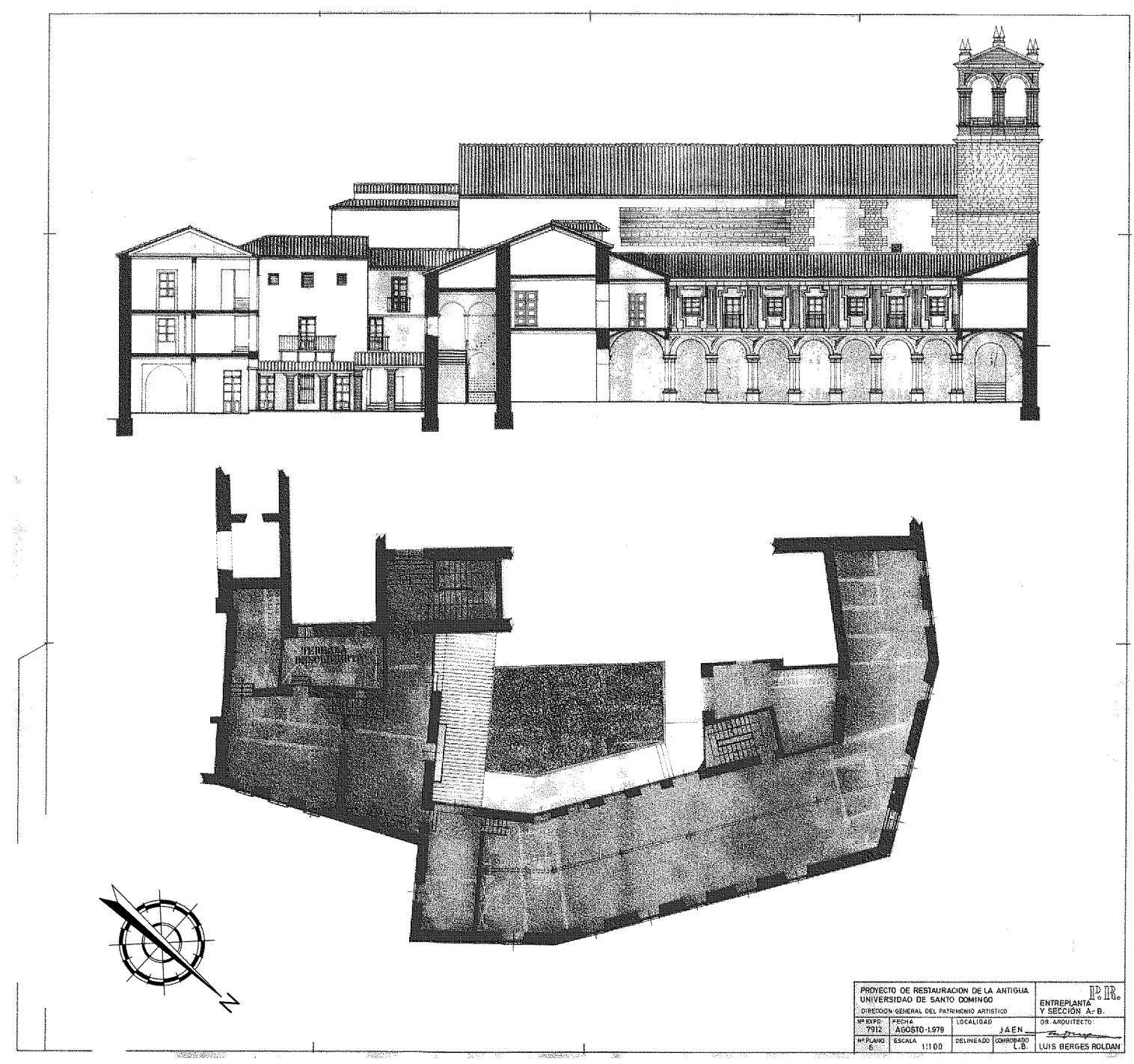

Fig. 15. Archivo Histórico Entreplanta y Sección Interior 


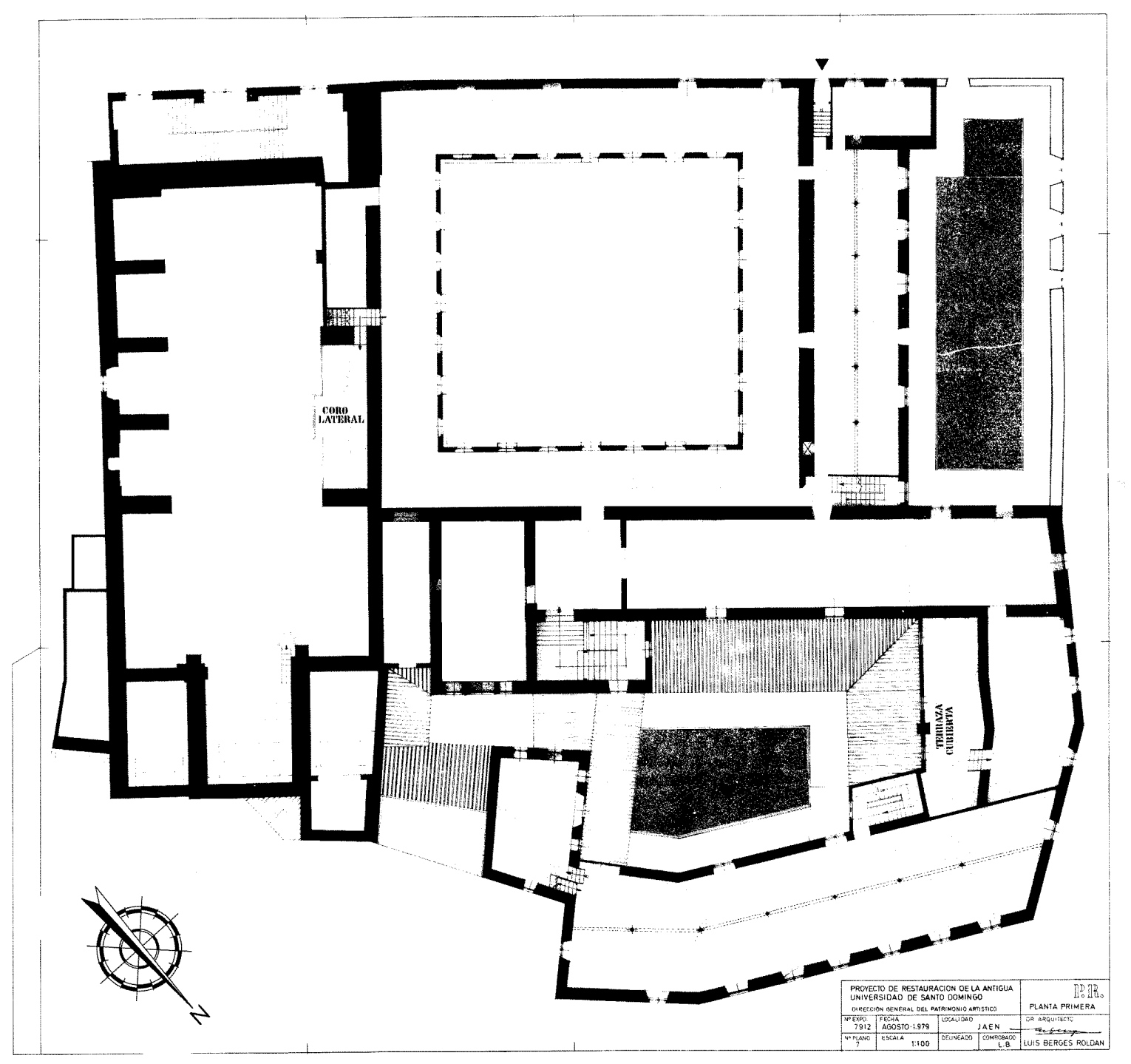

Fig. 16. Archivo Histórico Planta $1^{\underline{a}}$ 


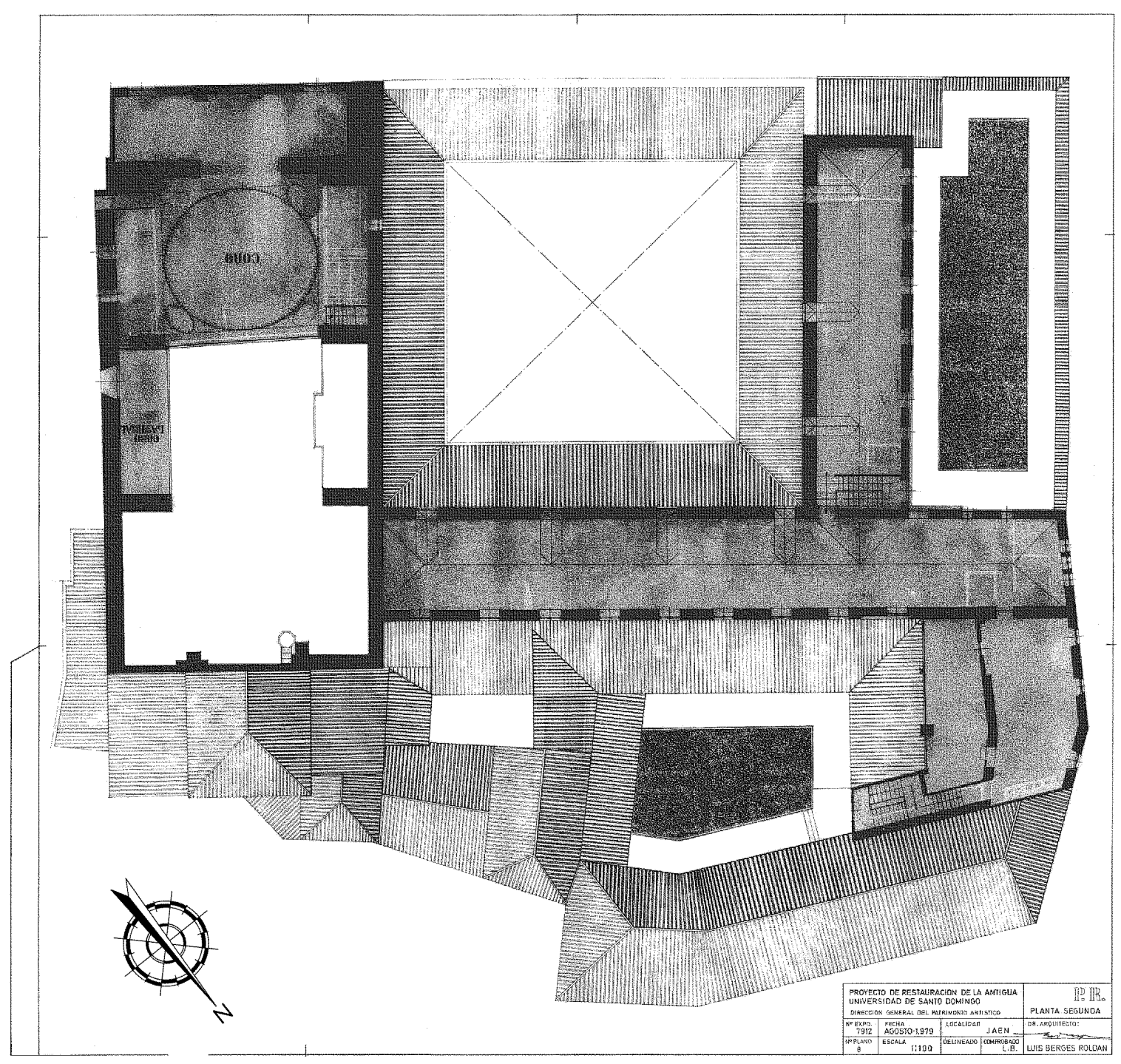

Fig. 17. Archivo Histórico Planta 2a 


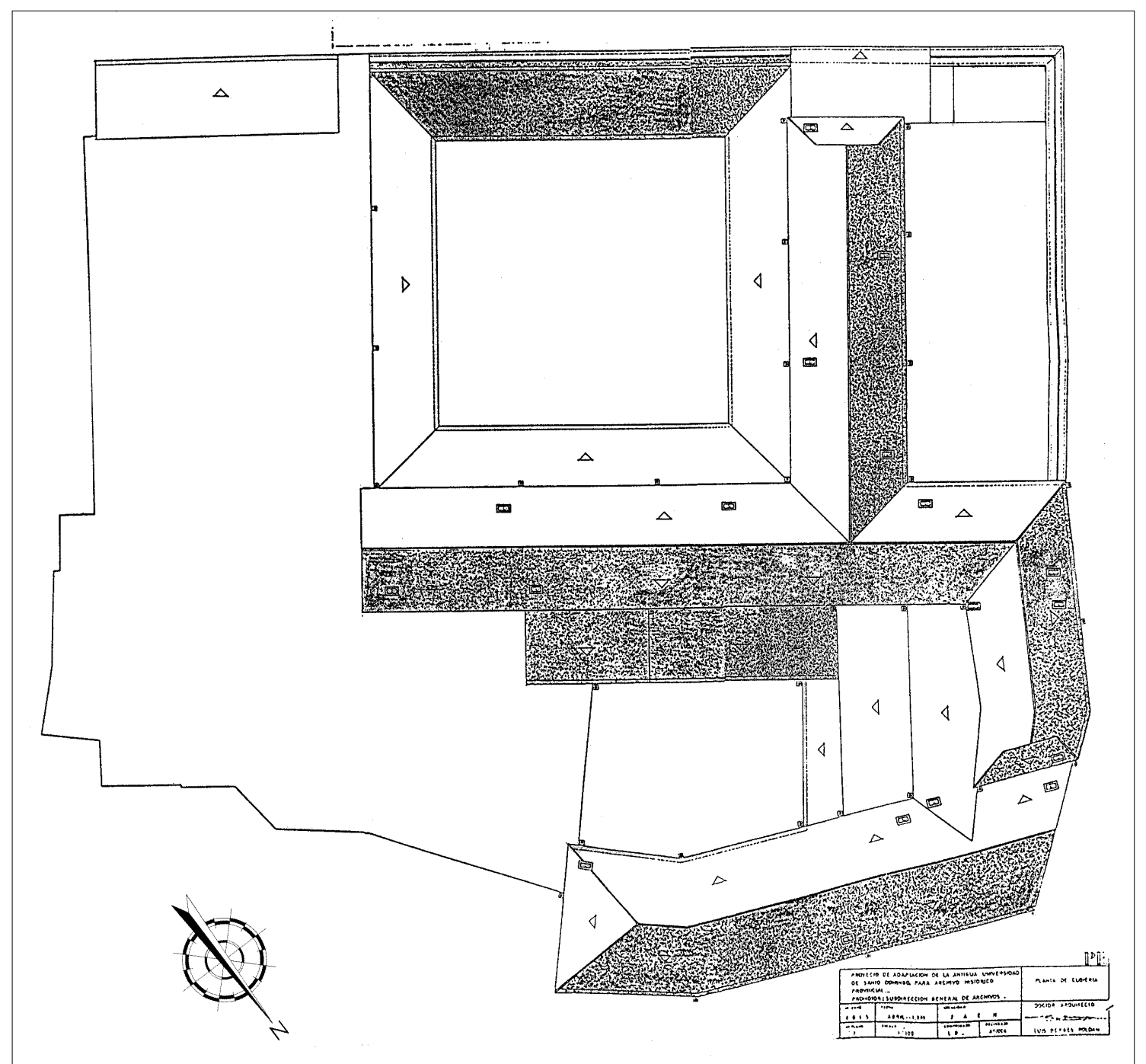

Fig. 18. Archivo Histórico Cubiertas 


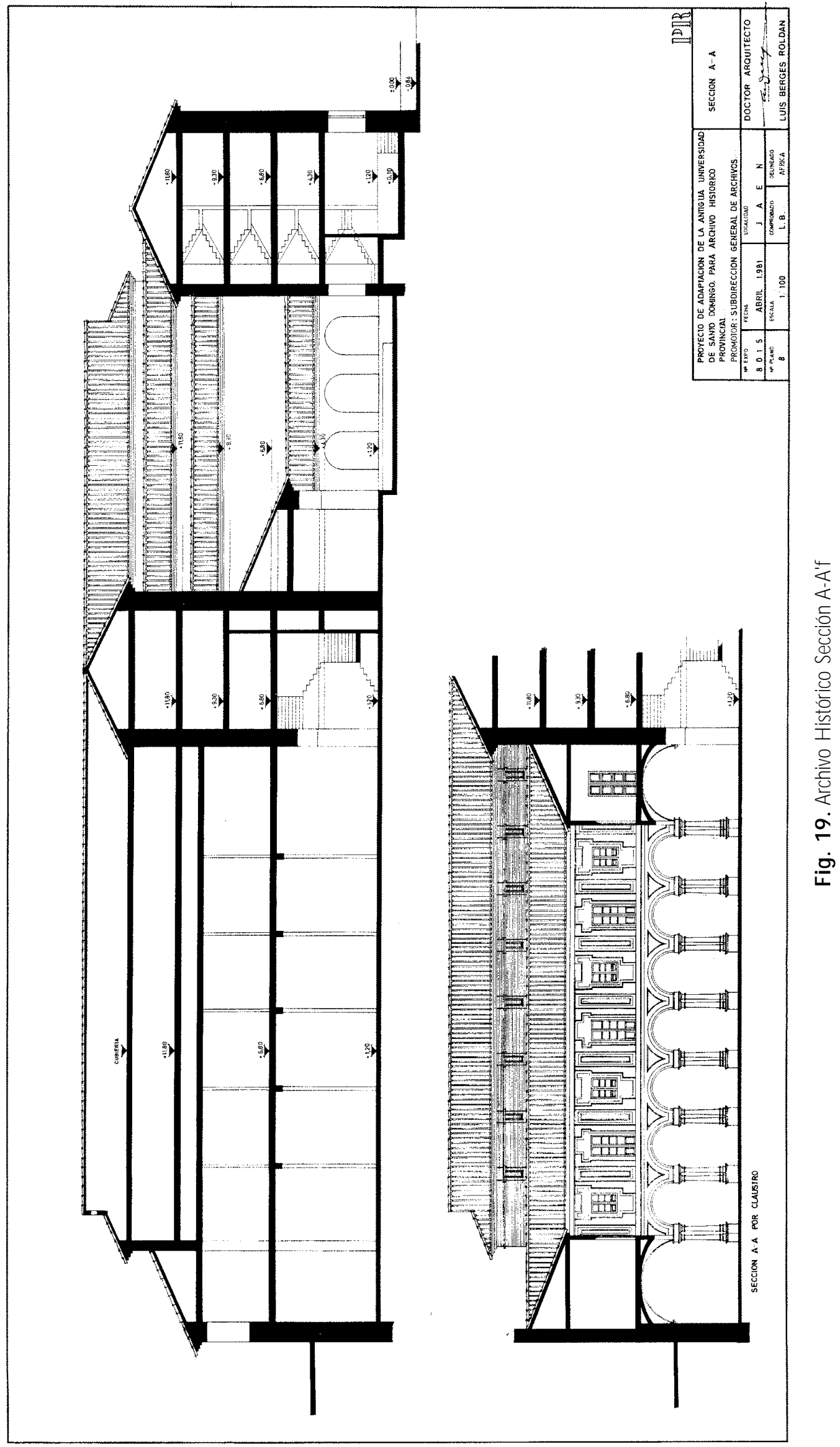




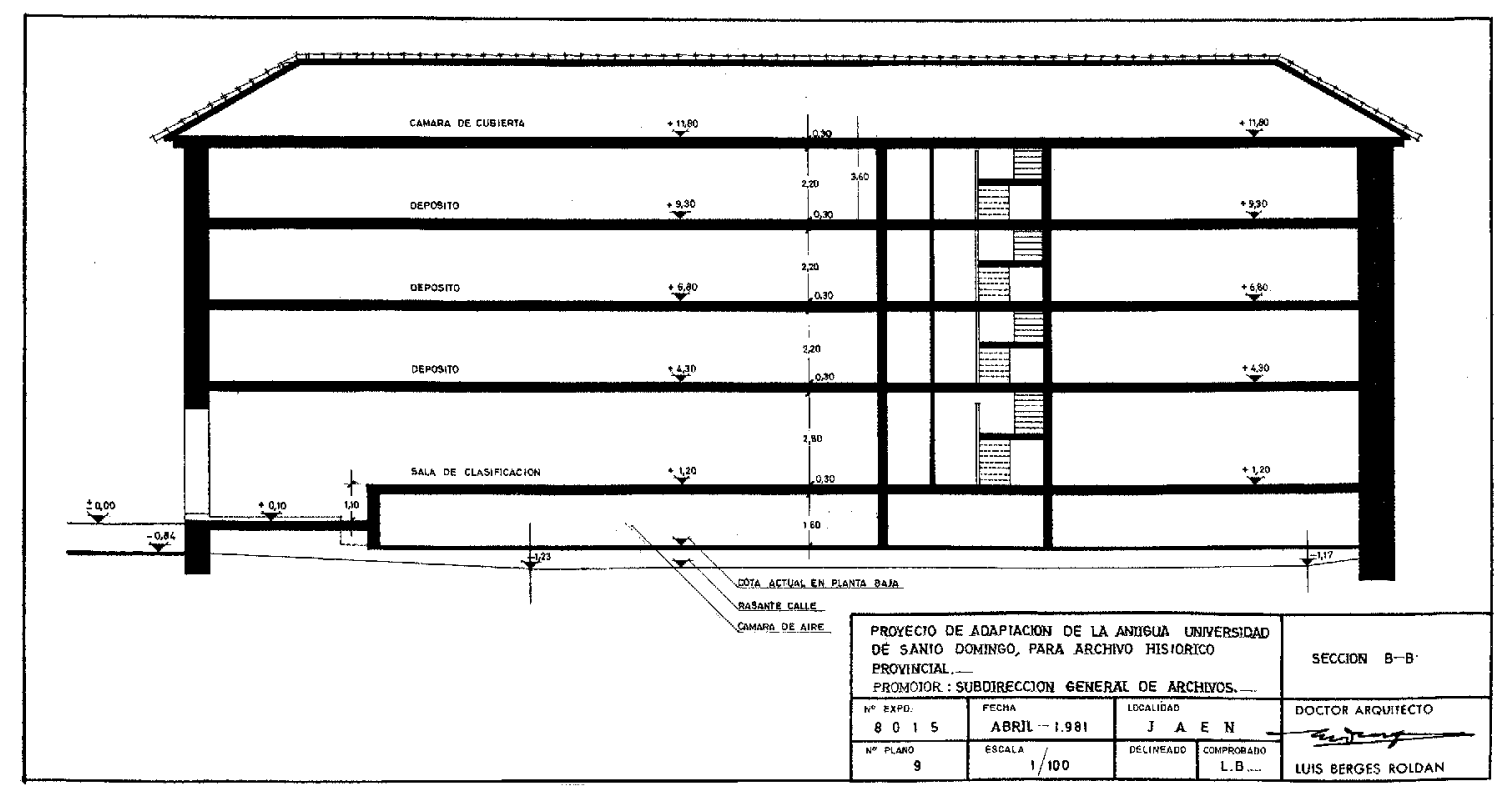

Fig. 20. Archivo H istórico Sección B-B'.jpg

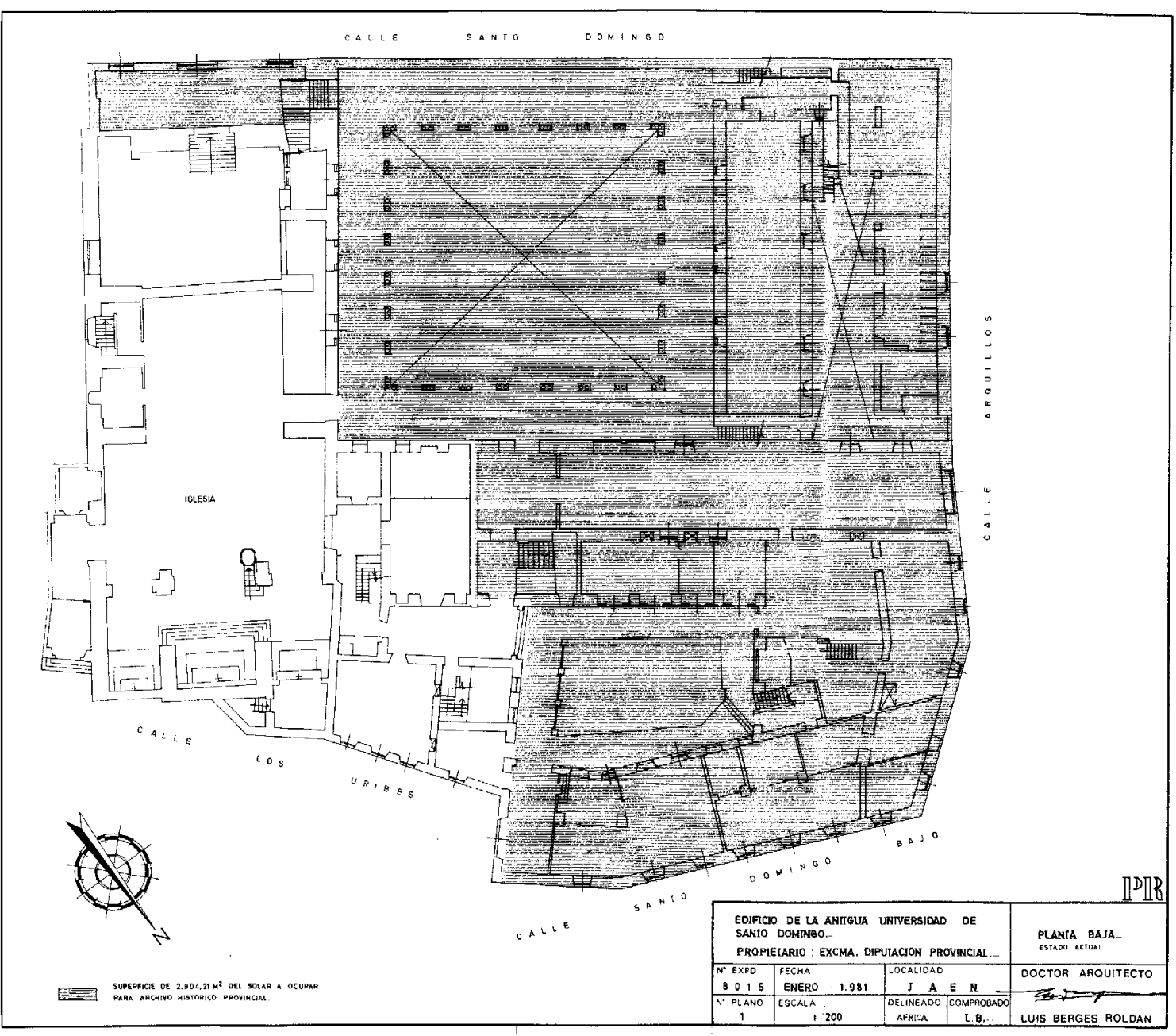

Fig. 21. Archivo Histórico Planta Baja 


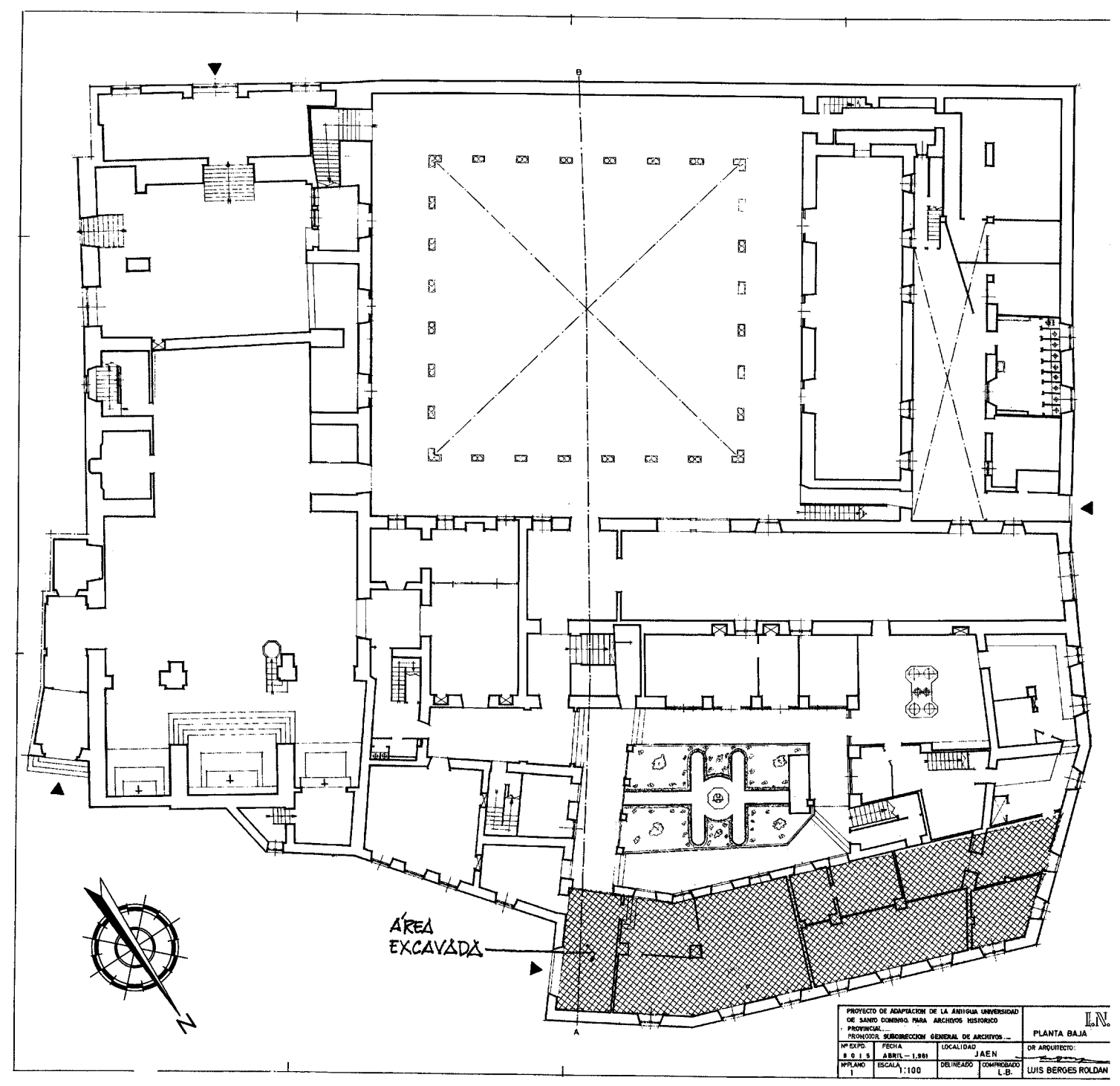

Fig. 22. Archivo Histórico Planta Baja 


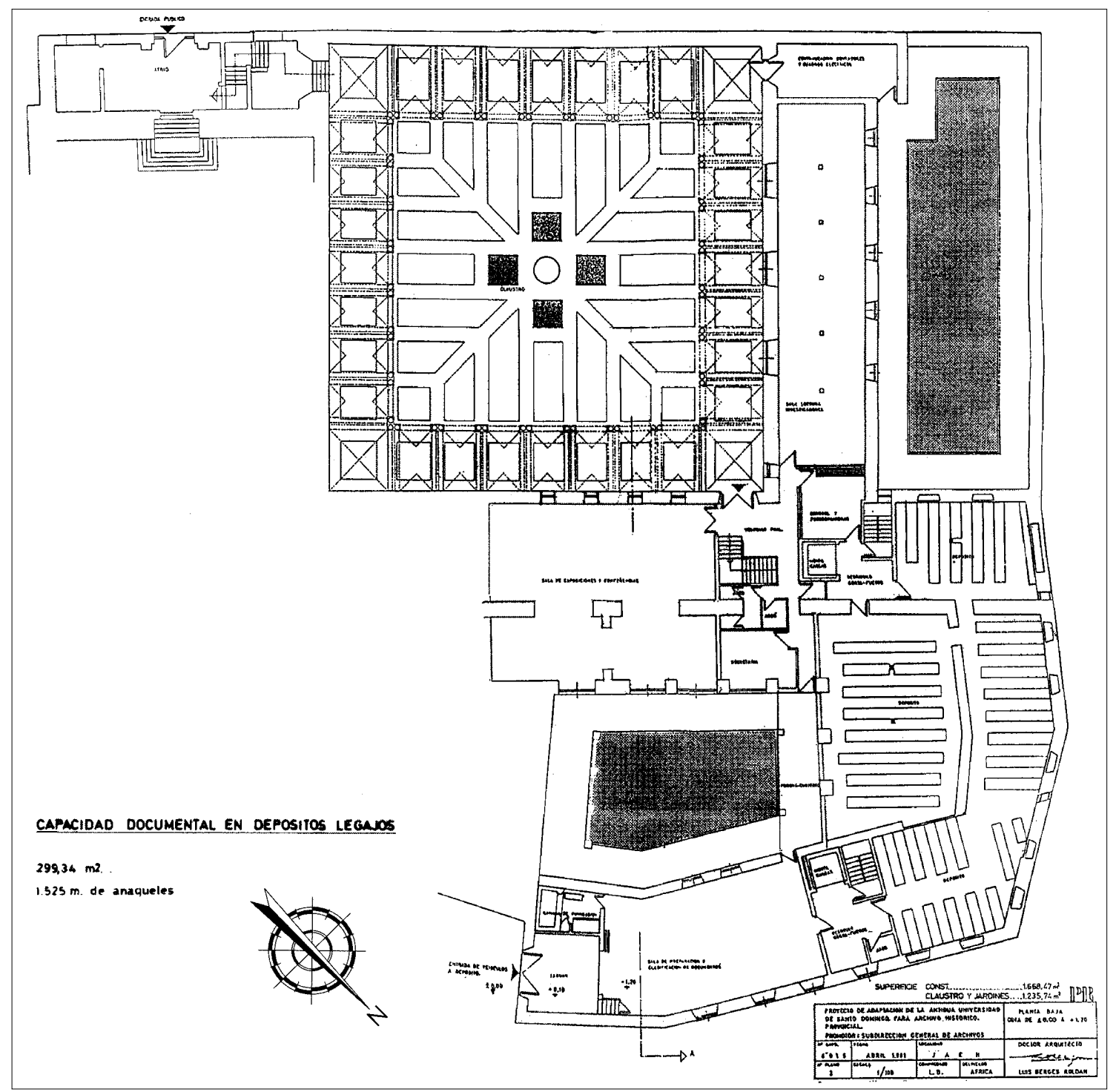

Fig. 23. Archivo Histórico Planta Baja 


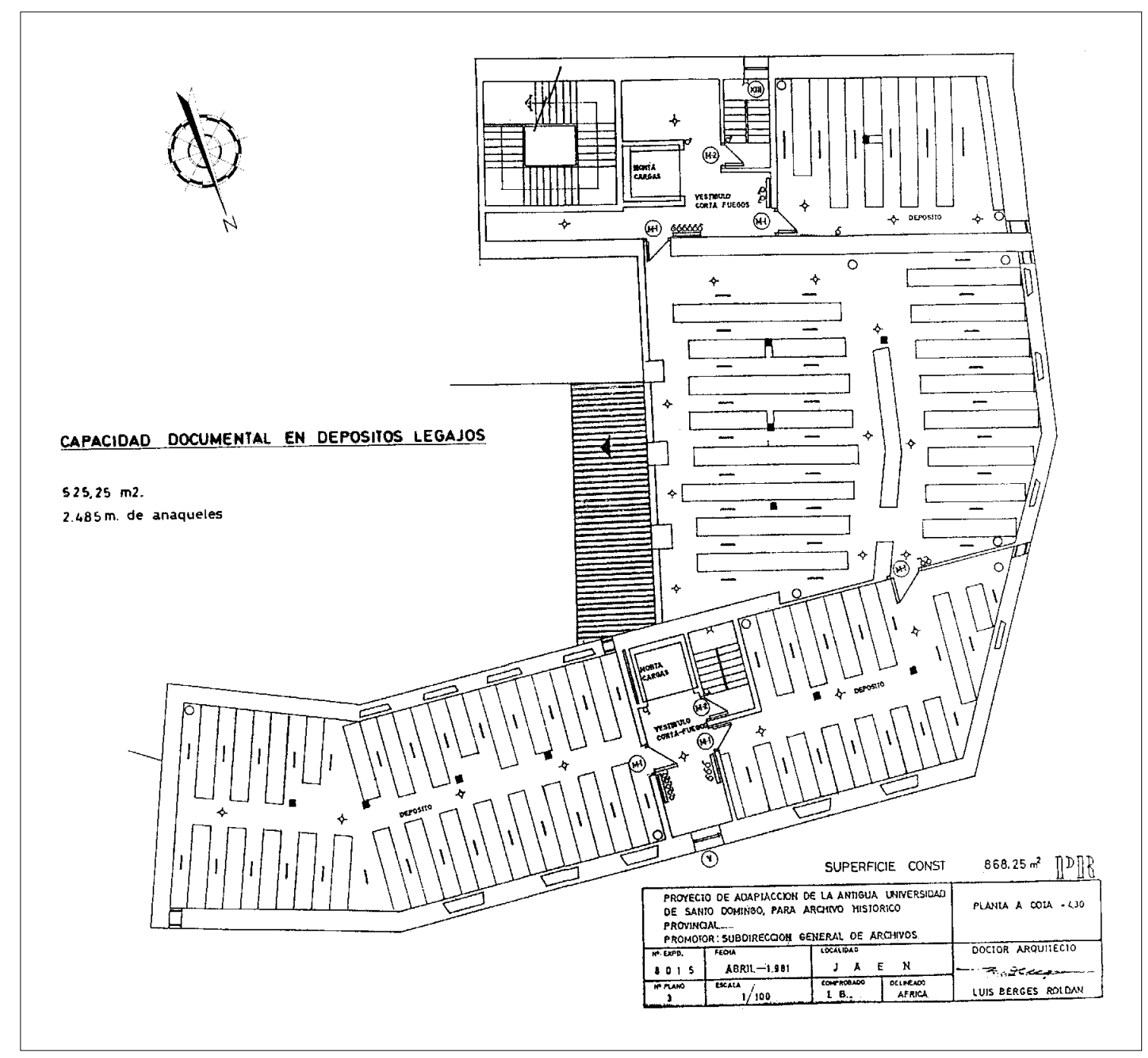

Fig. 24. Archivo Histórico Planta a 4,30 


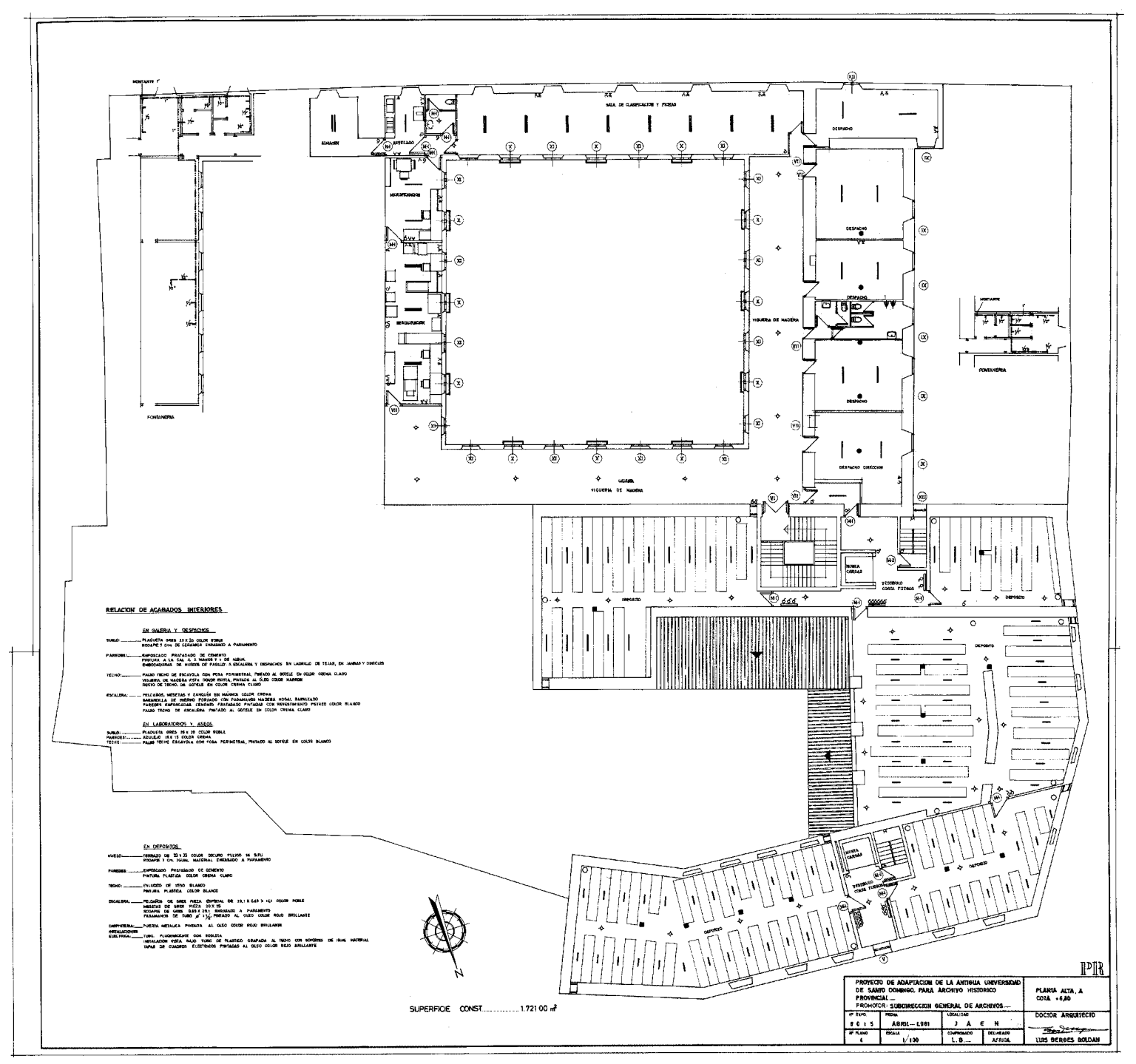

Fig. 25. Archivo Histórico Planta a 6,30 


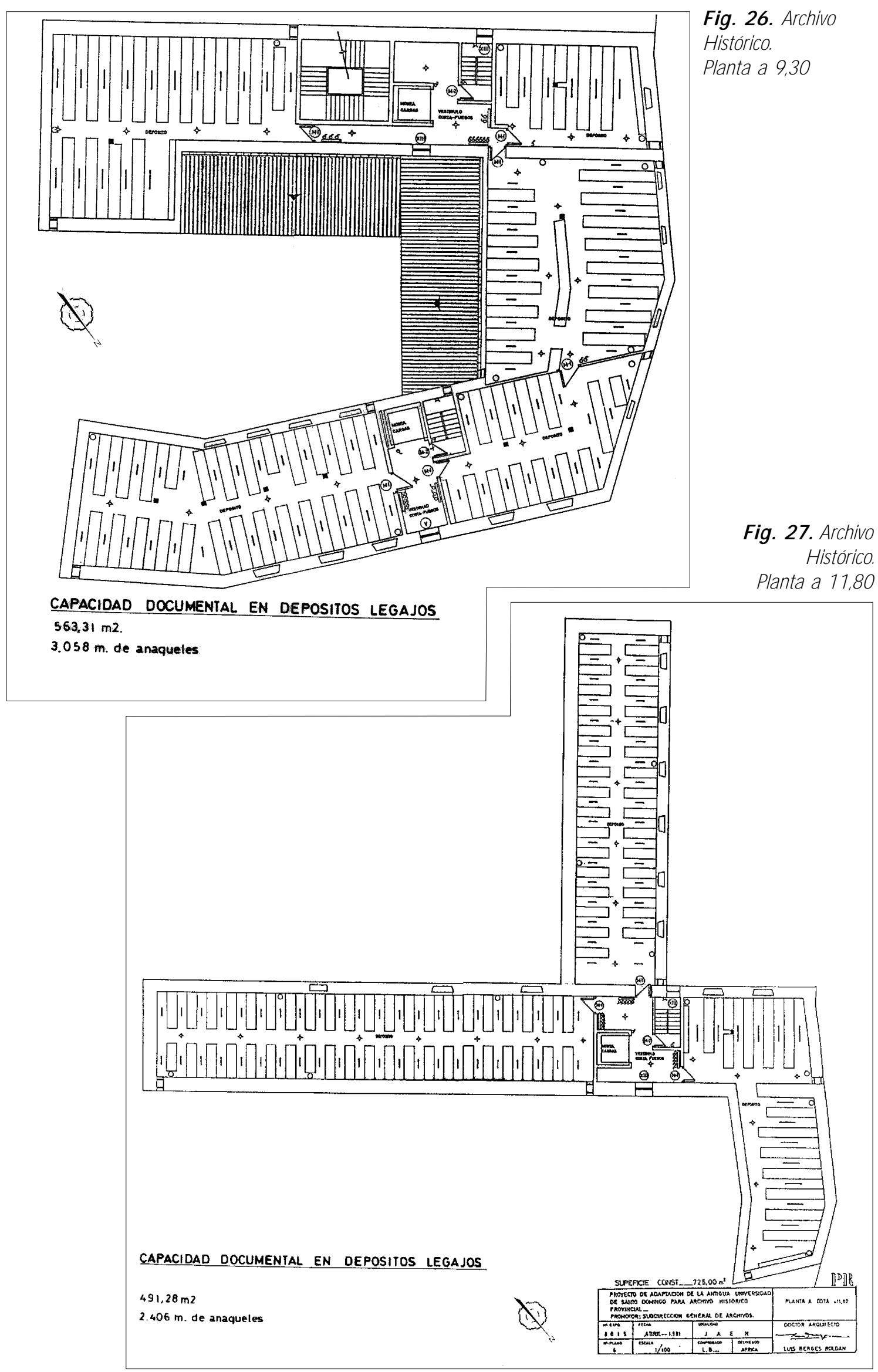




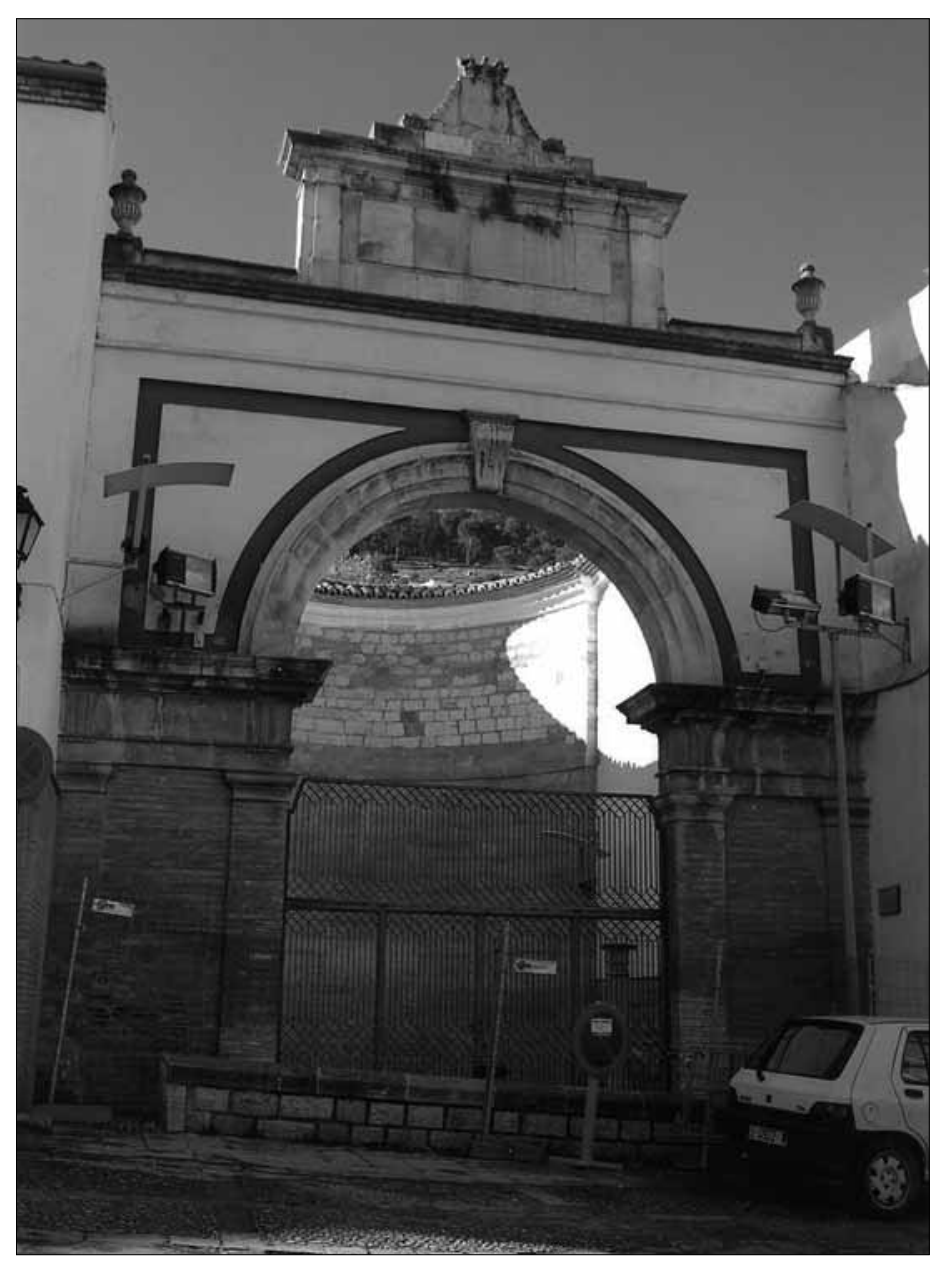

Lám. 1. Estado actual del manantial de La Magdalena. Portada de acceso.
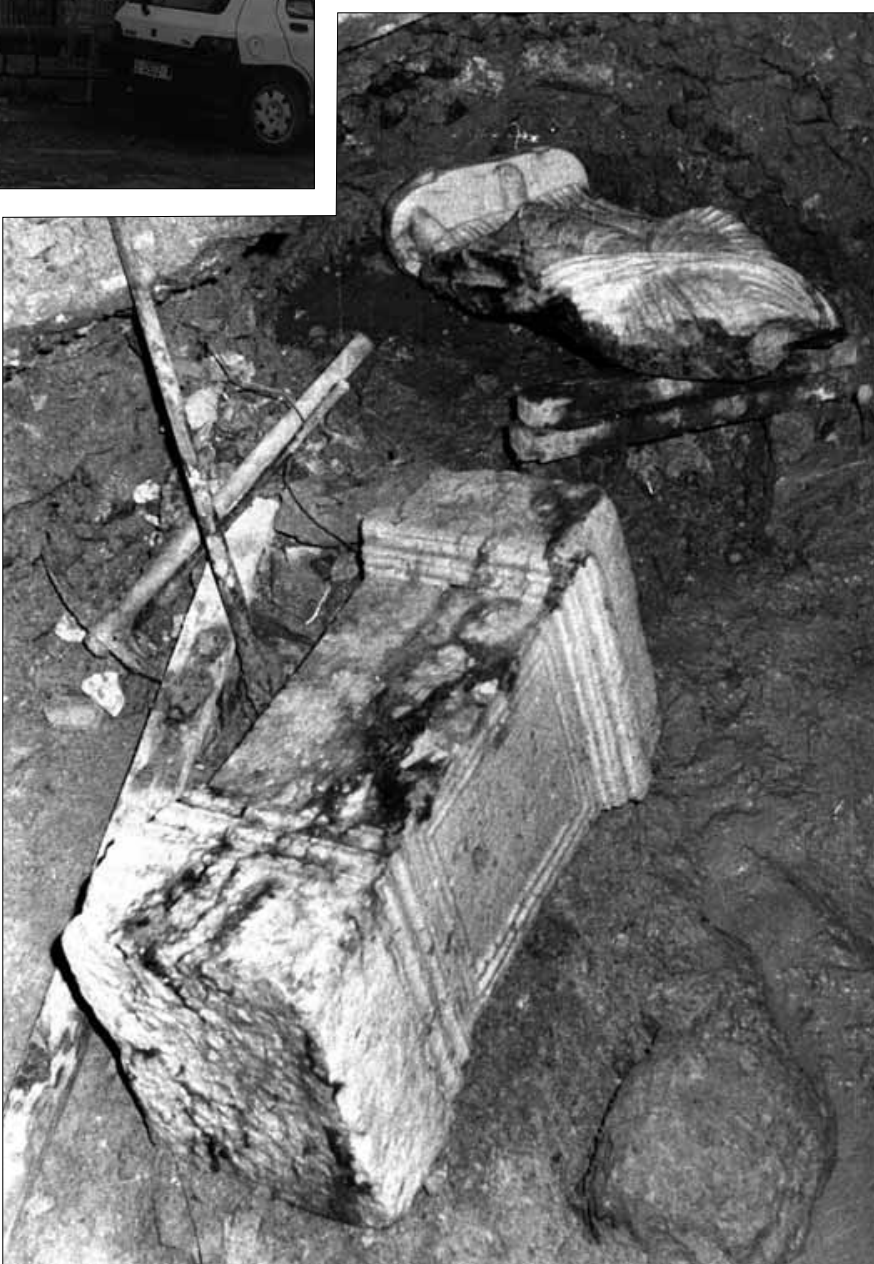

Lám. 2. Pedestal y togado femenino tal y como se encontraron (foto Ortega) 


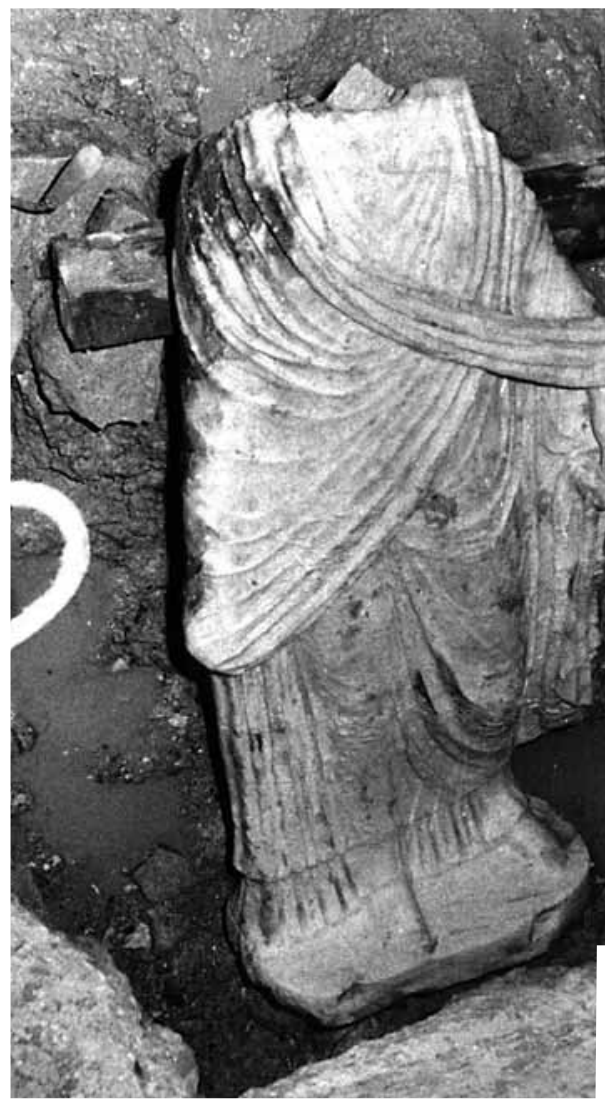

Lám. 3. El togado femenino (Foto Ortega)

Lám. 4. El oficial de albañilería Cándido

Méndez junto al conjunto de pedestal y togado femenino (foto Ortega)

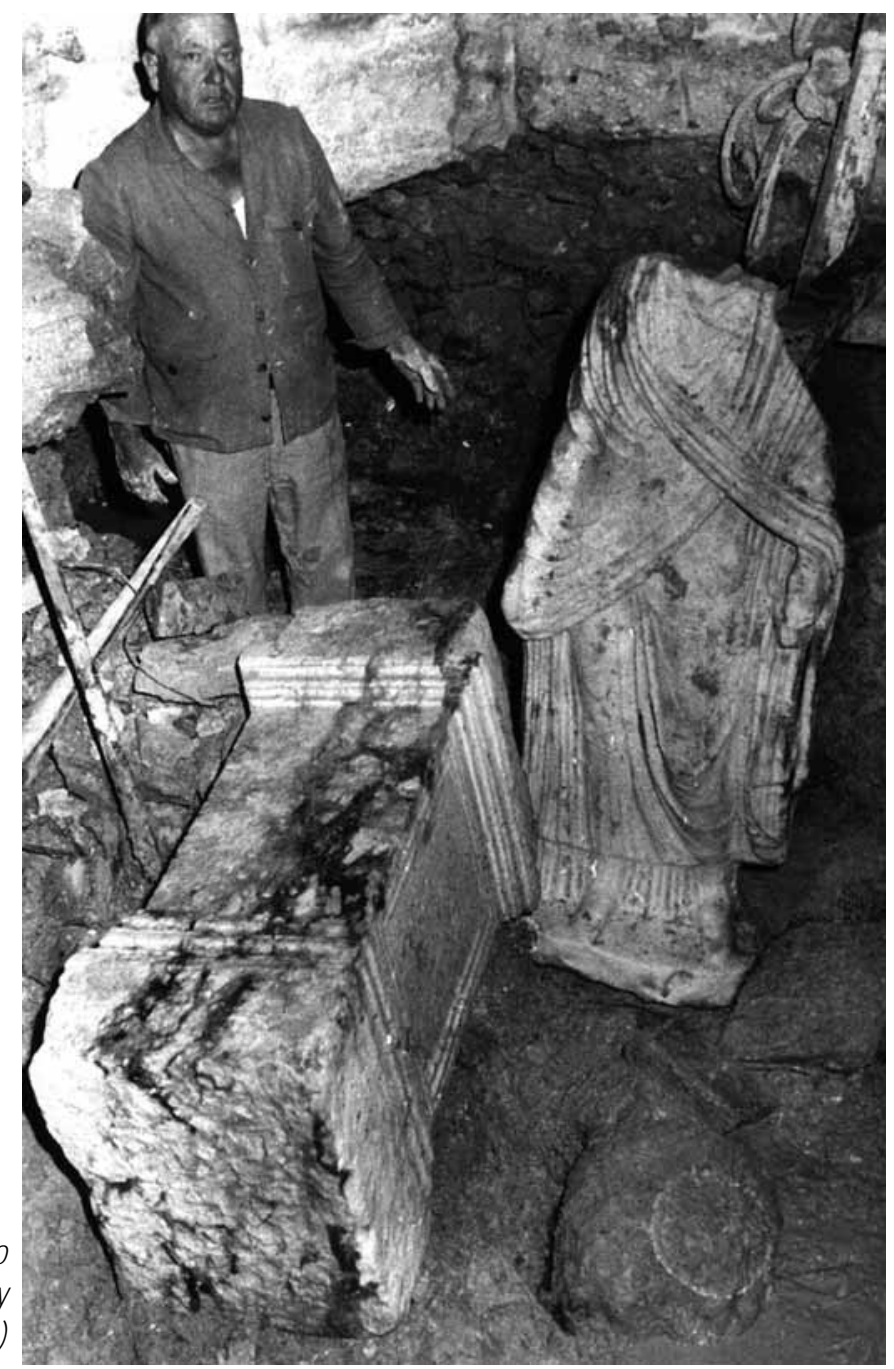




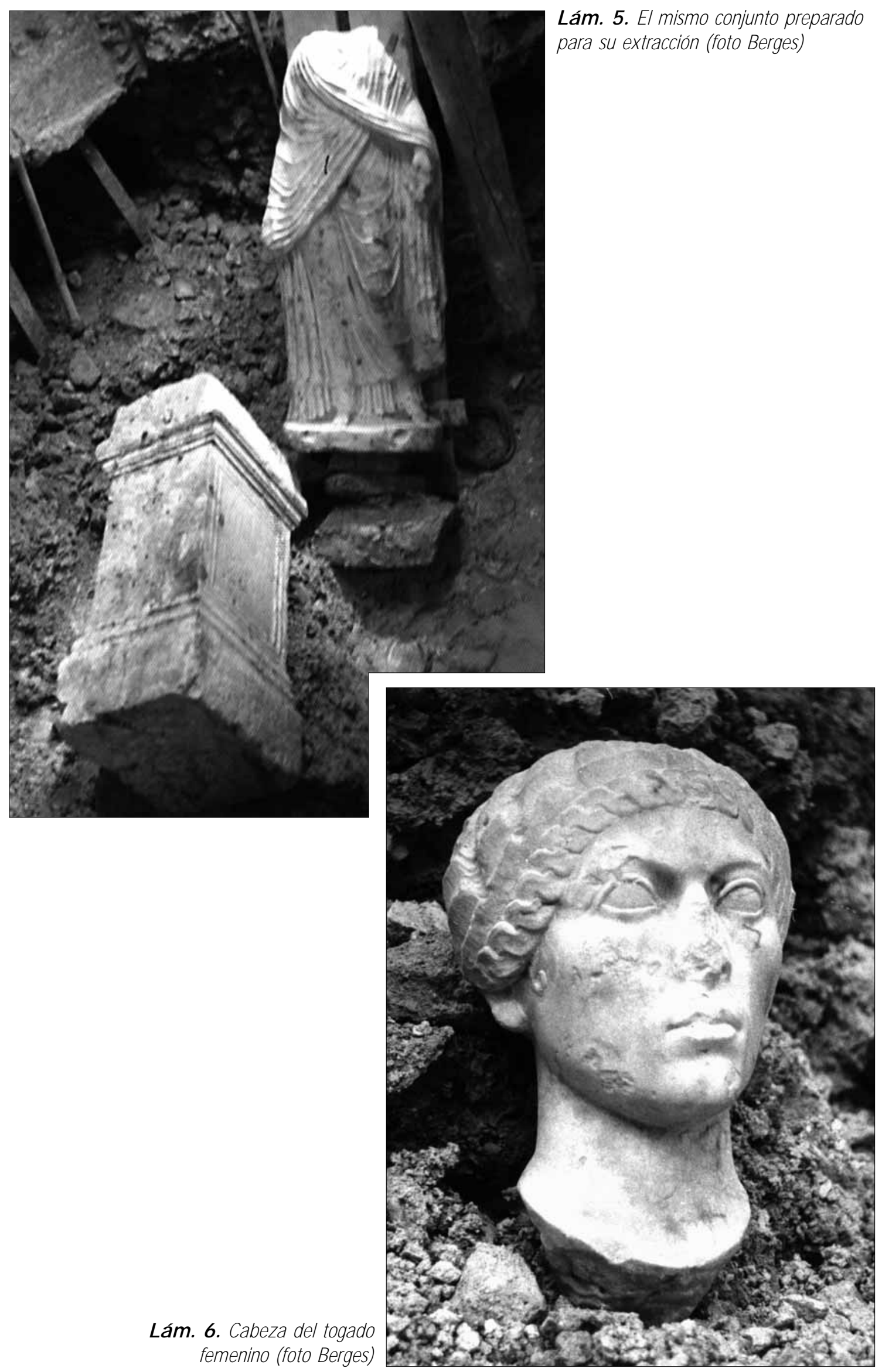



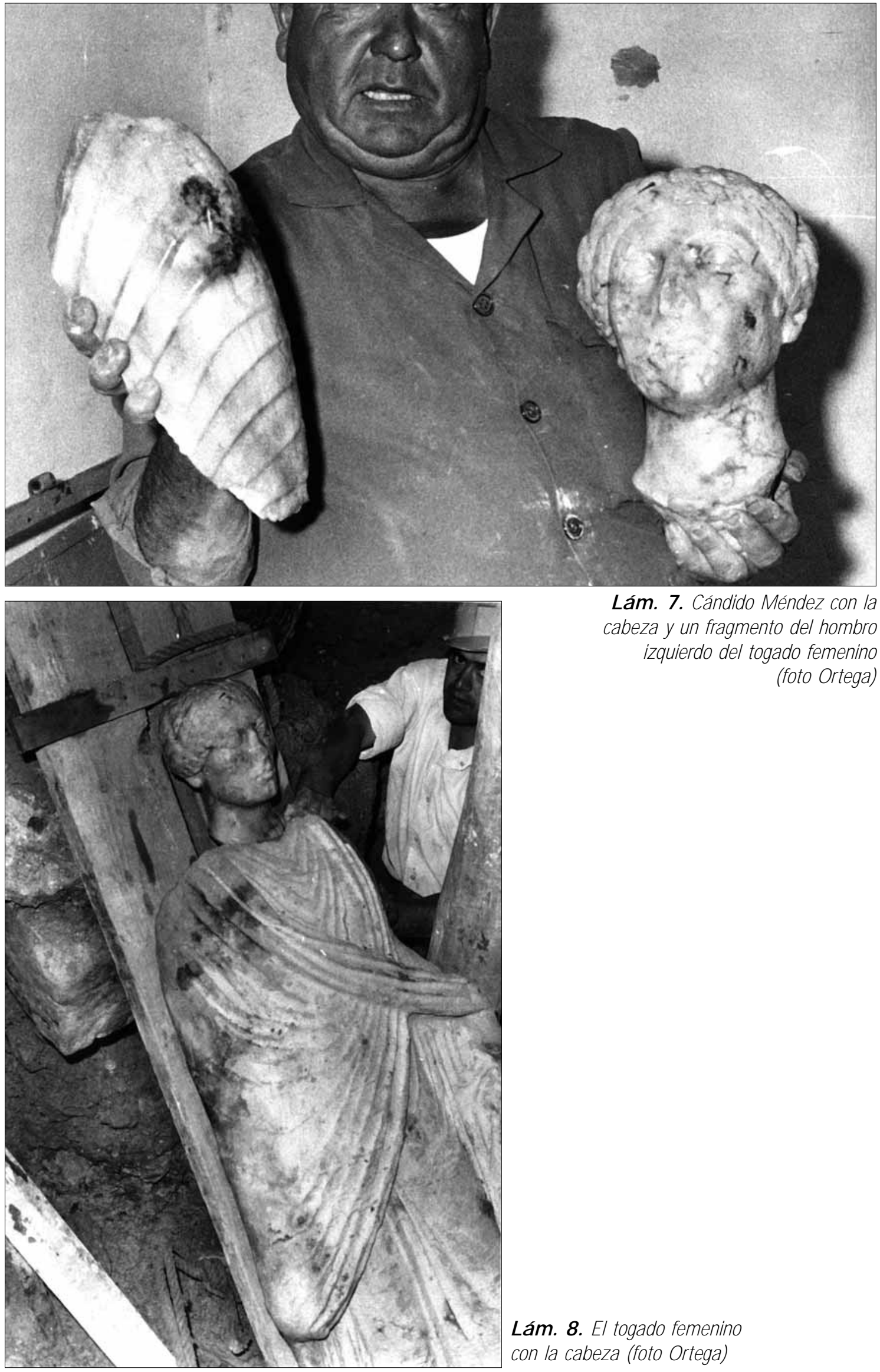

Lám. 7. Cándido Méndez con la cabeza y un fragmento del hombro izquierdo del togado femenino (foto Ortega)

Lám. 8. El togado femenino con la cabeza (foto Ortega) 


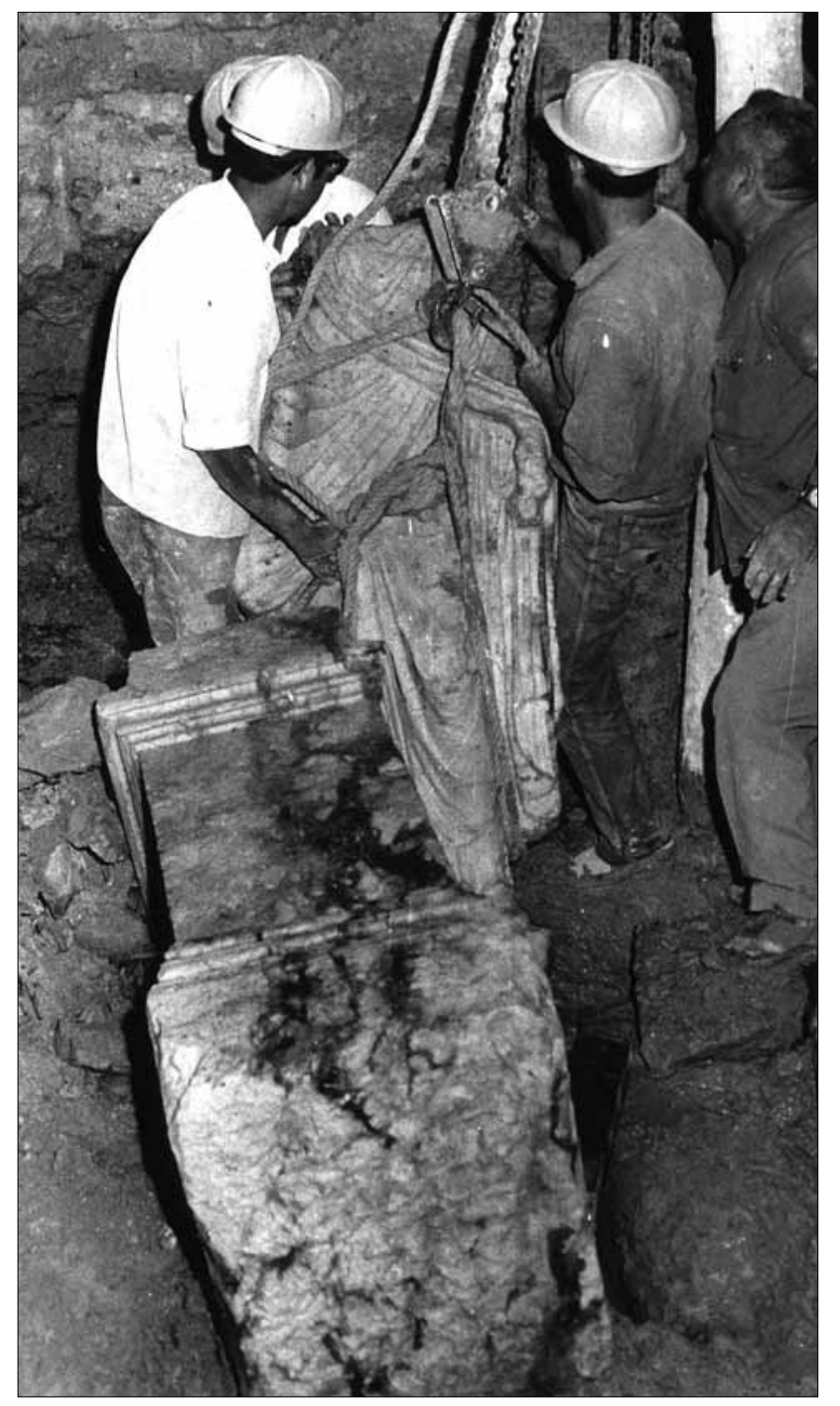

Lám. 9. Operación de izado del

togado femenino (foto Ortega)

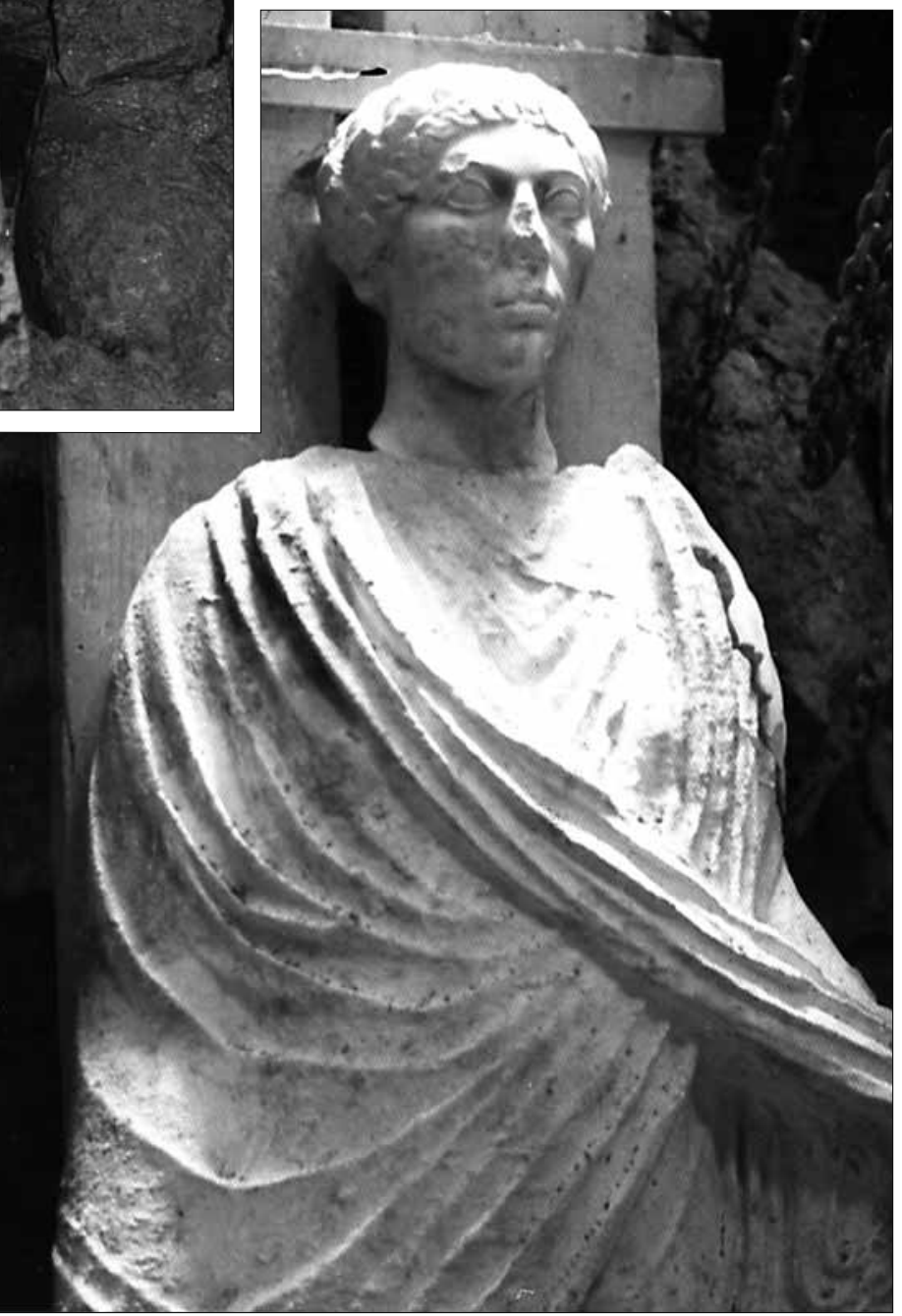

Lám. 10. Detalle parcial del togado femenino, completado con la cabeza y el hombro izquierdo (foto Berges) 


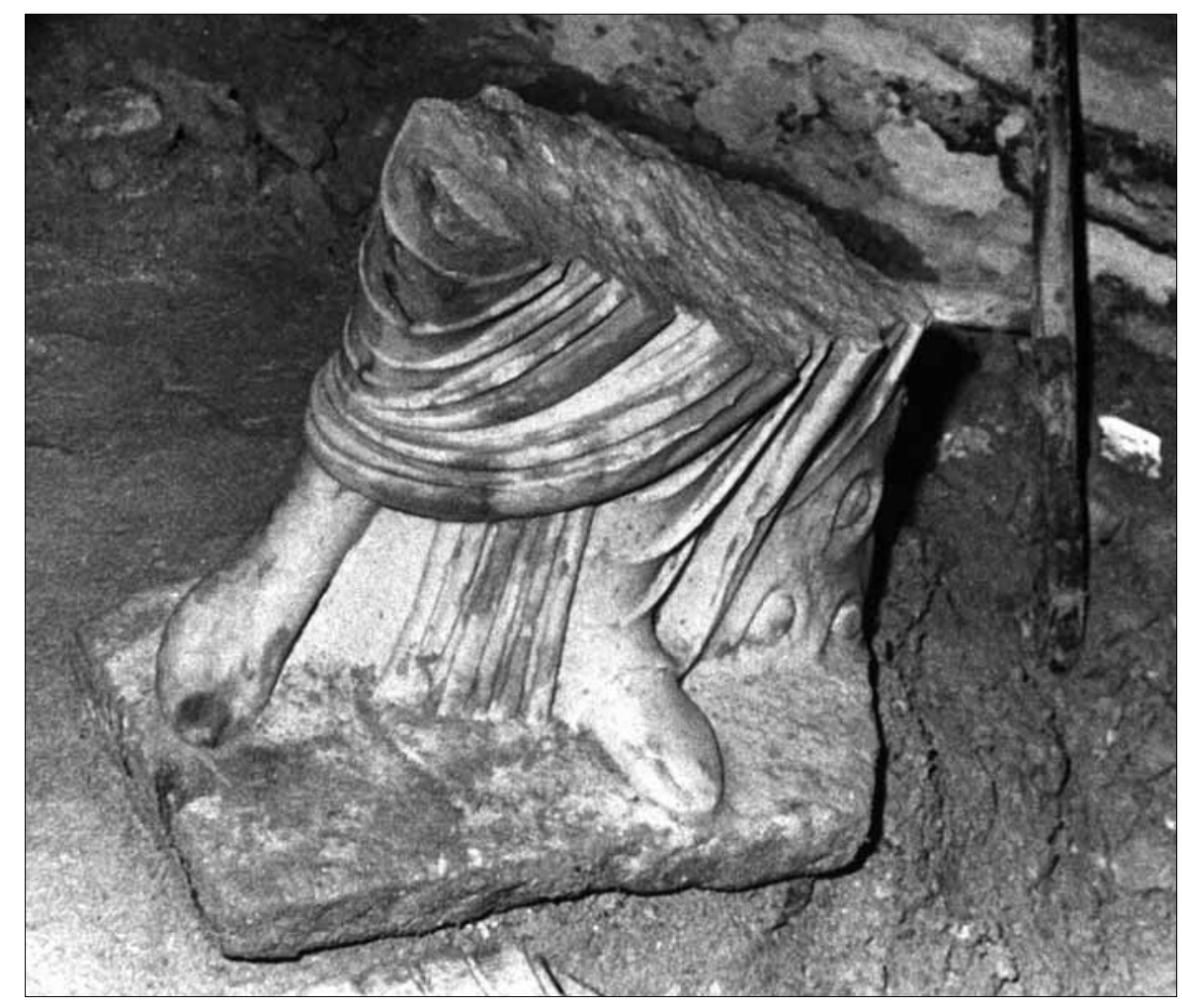

Lám. 11. Fragmento inferior del togado masculino tal como apareció en la excavación (foto Ortega)

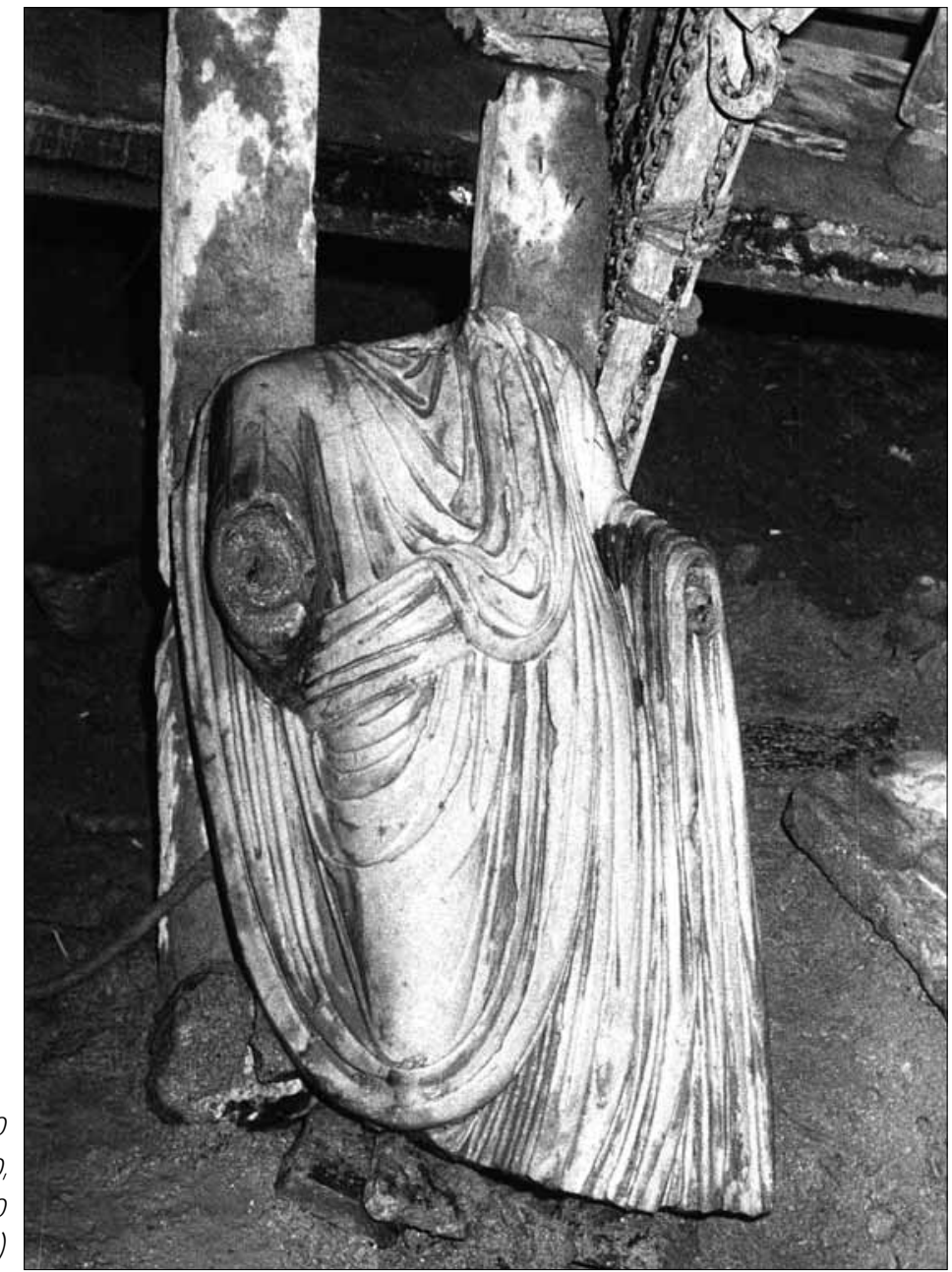

(foto Ortega) 


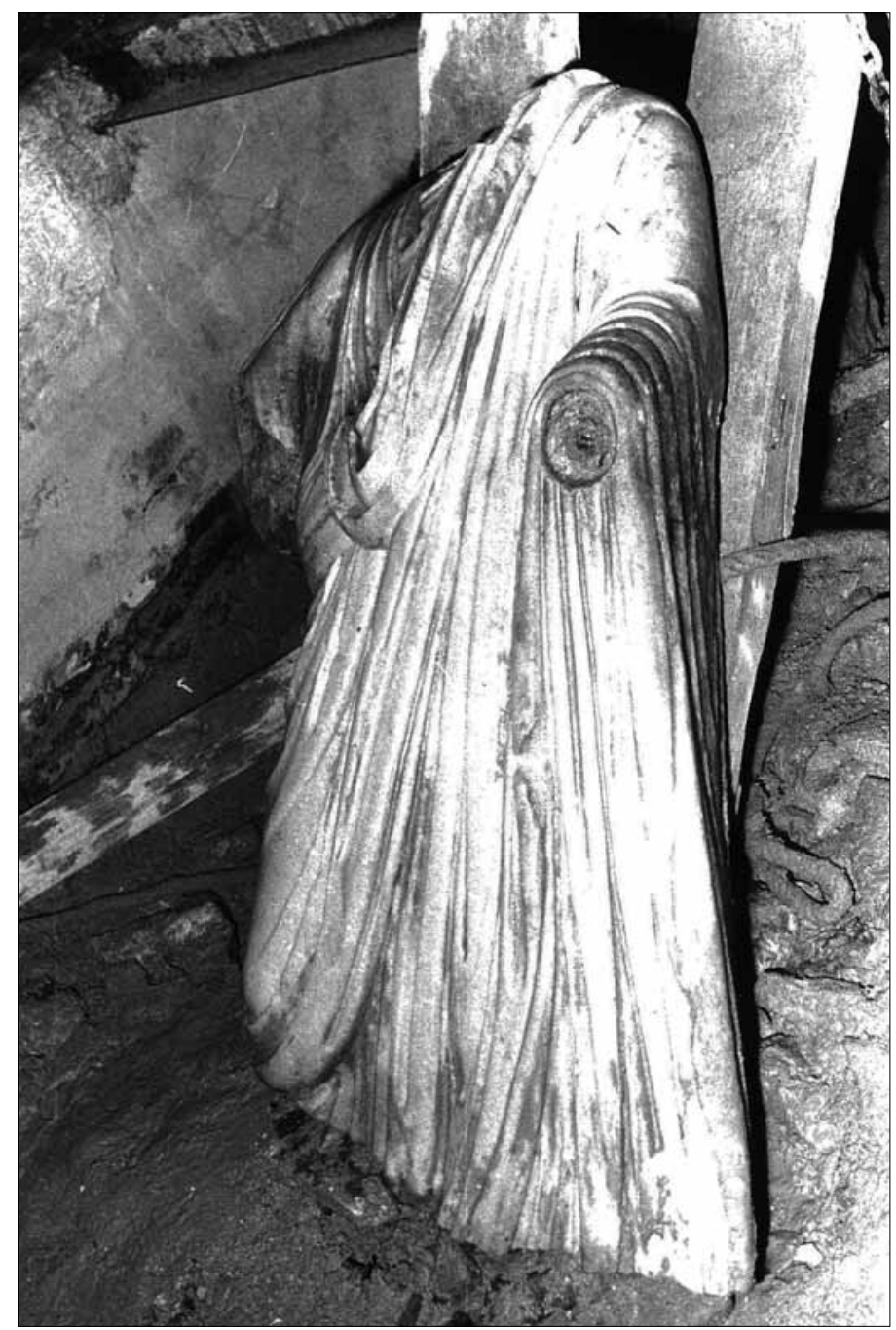

Lám. 13. Otra vista del fragmento

superior del togado masculino

(foto Ortega)

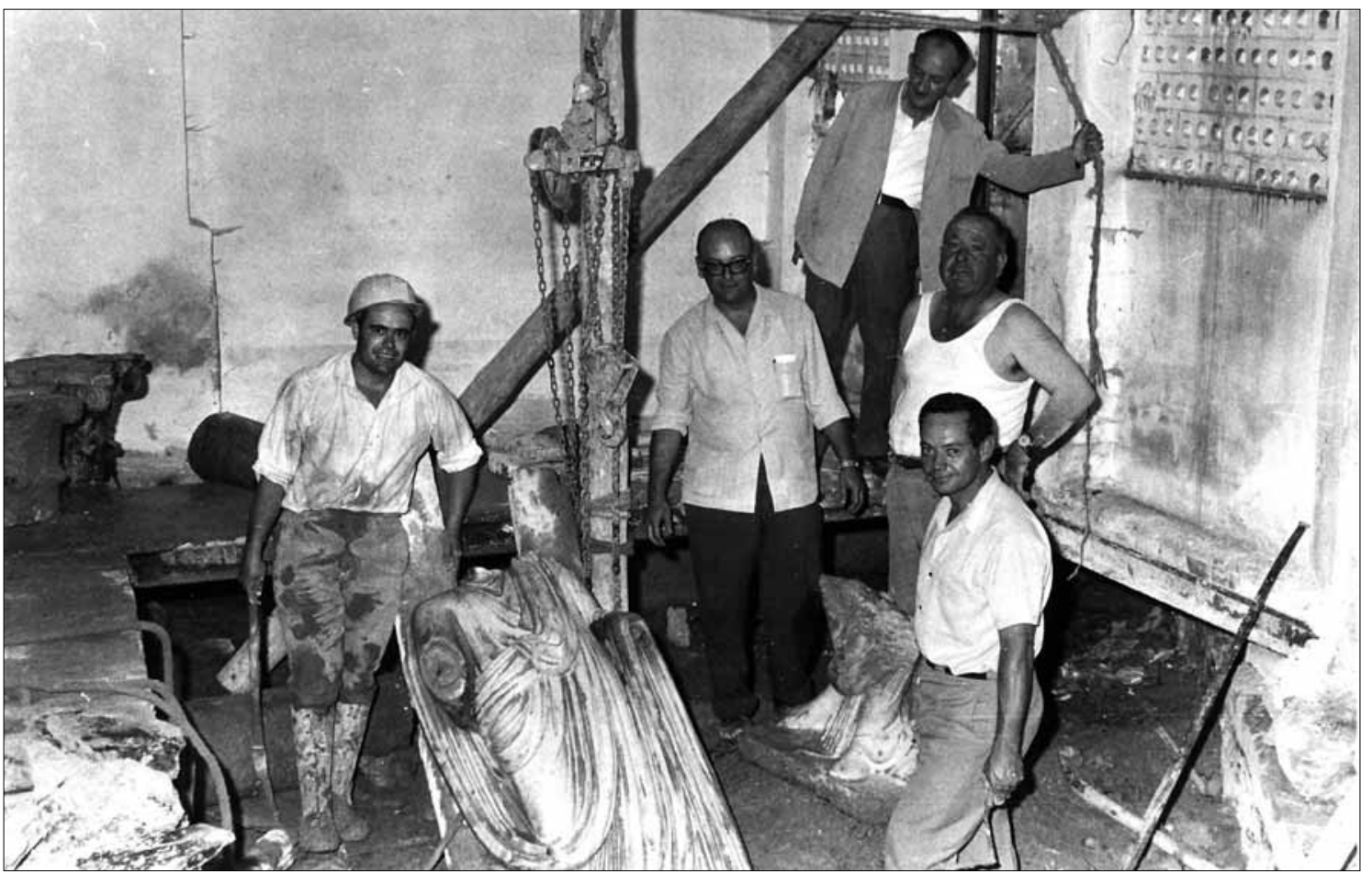




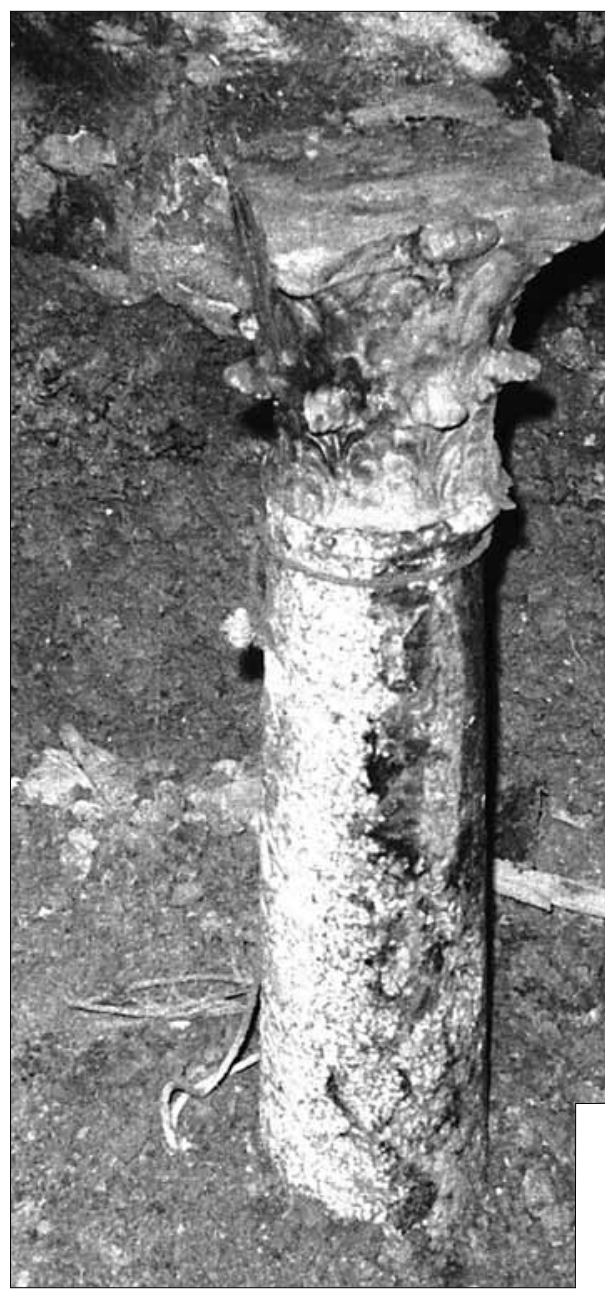

Lám. 15. Capitel corintio sobre fuste, con señales de calcinación por fuego (Foto Ortega)

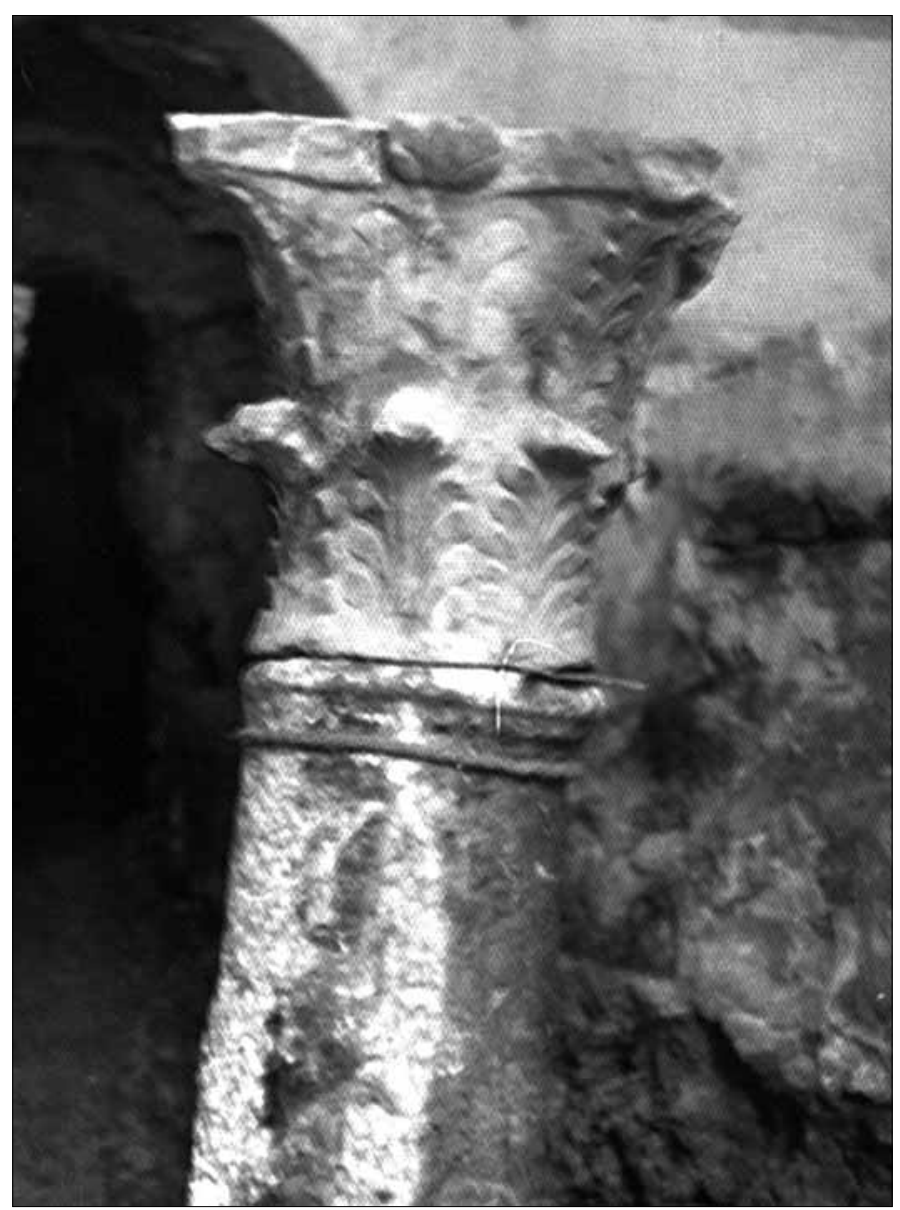




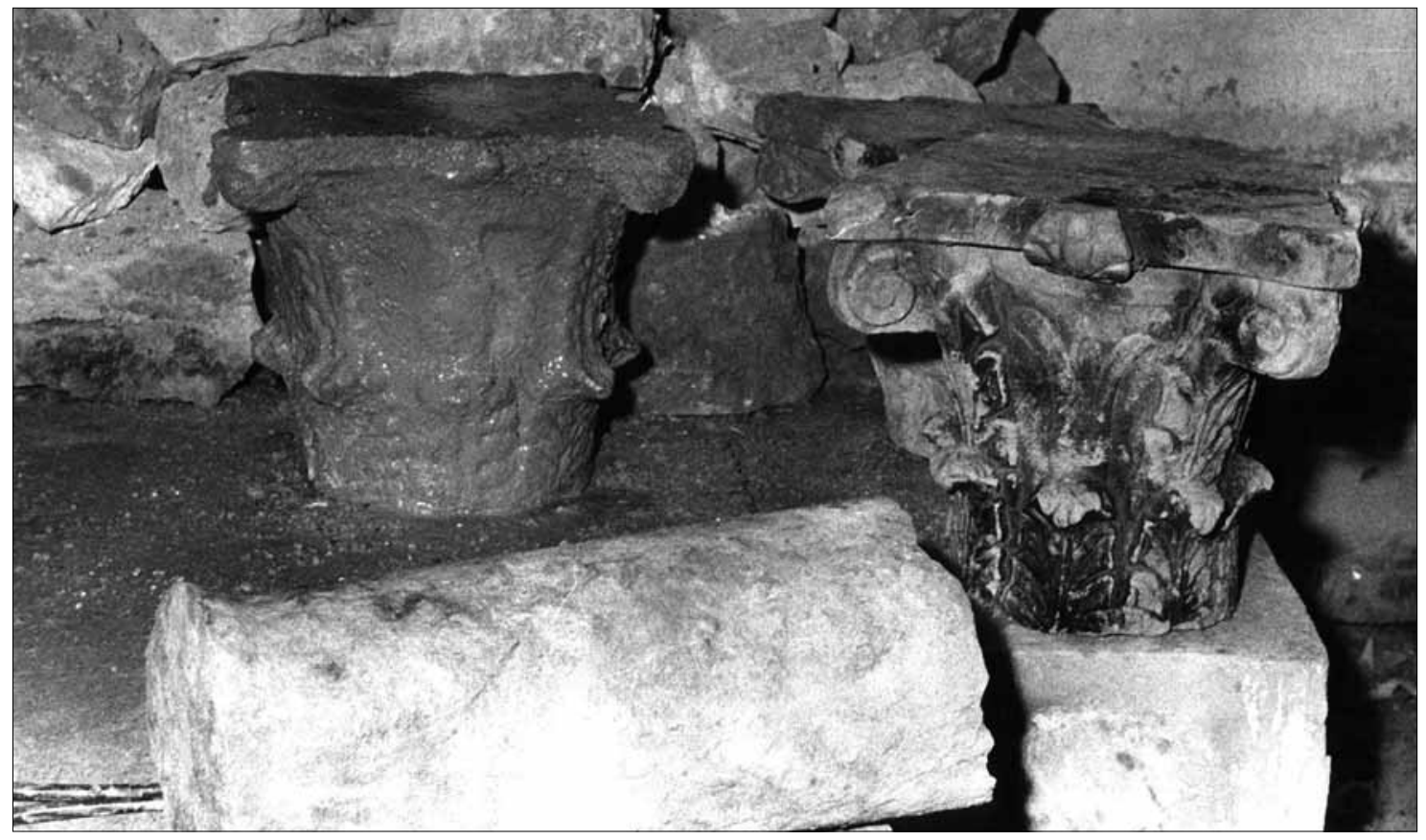

Lám. 17. Capiteles corintios, en uno se aprecian señales de calcinación. En primer término fragmento superior del fuste con collarino (Foto Ortega)

Lám. 18. La escultura del togado femenino en el patio central del Museo provincial de Jaén

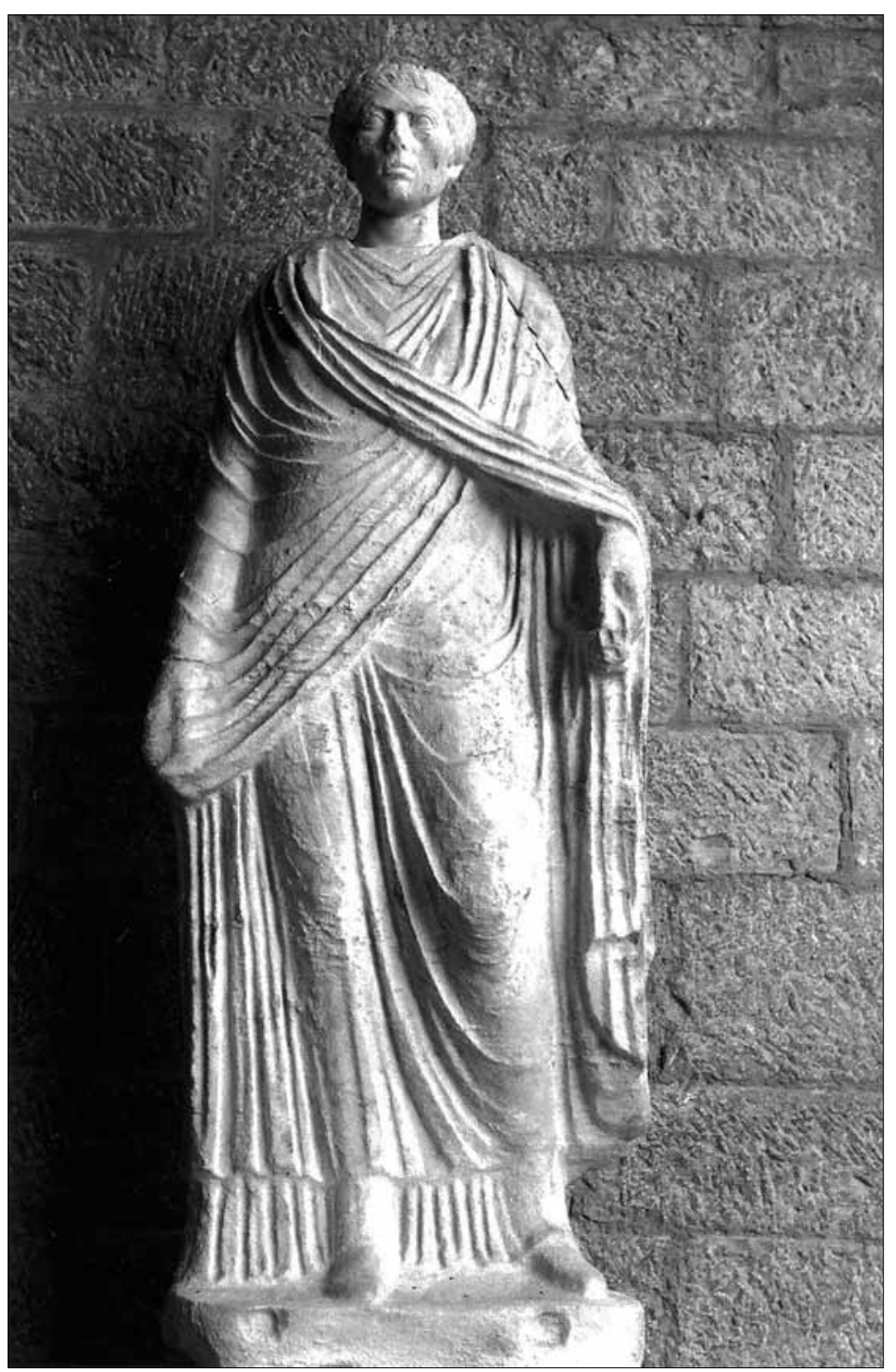




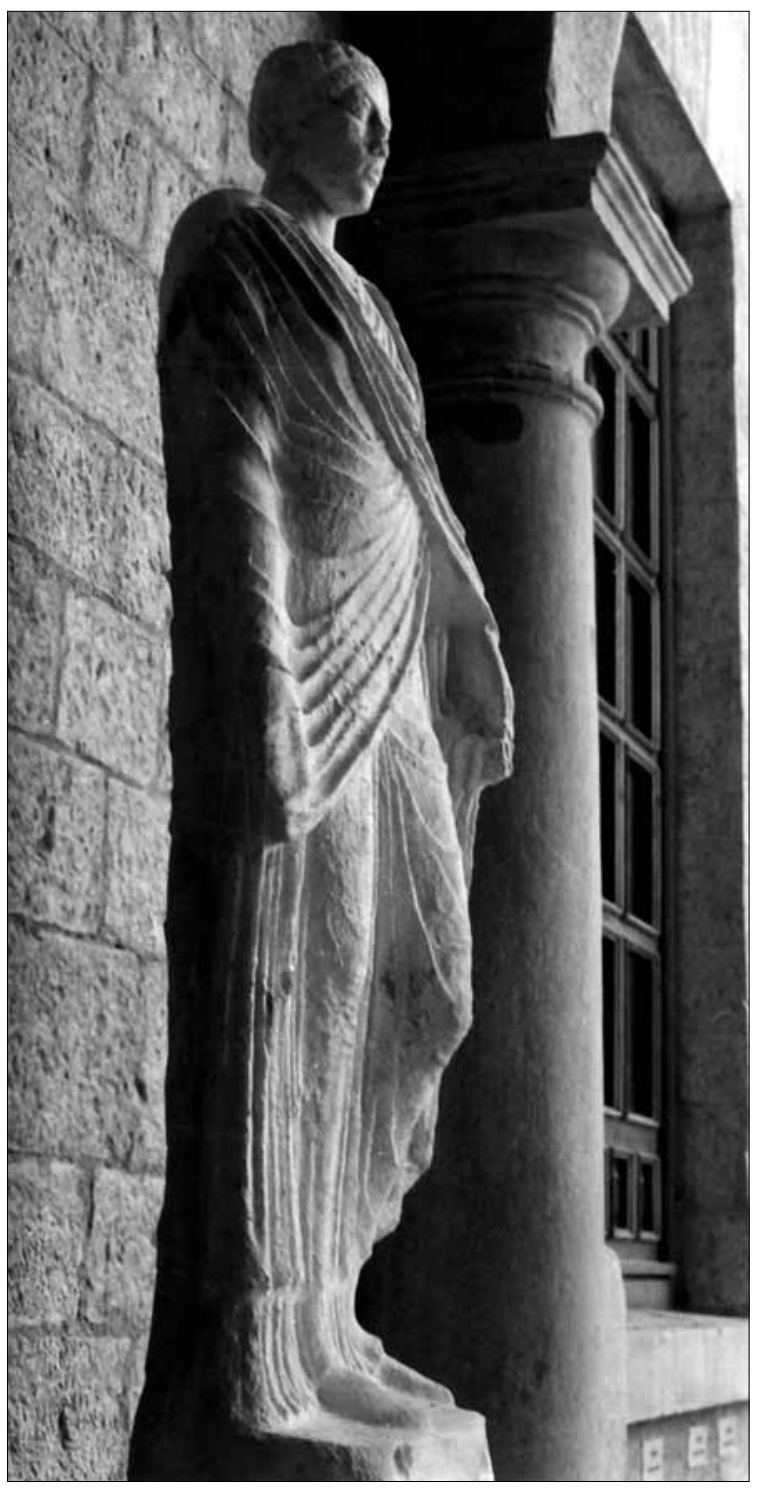

Lám. 19. La escultura del togado

femenino en el patio central del

Museo provincial de Jaén

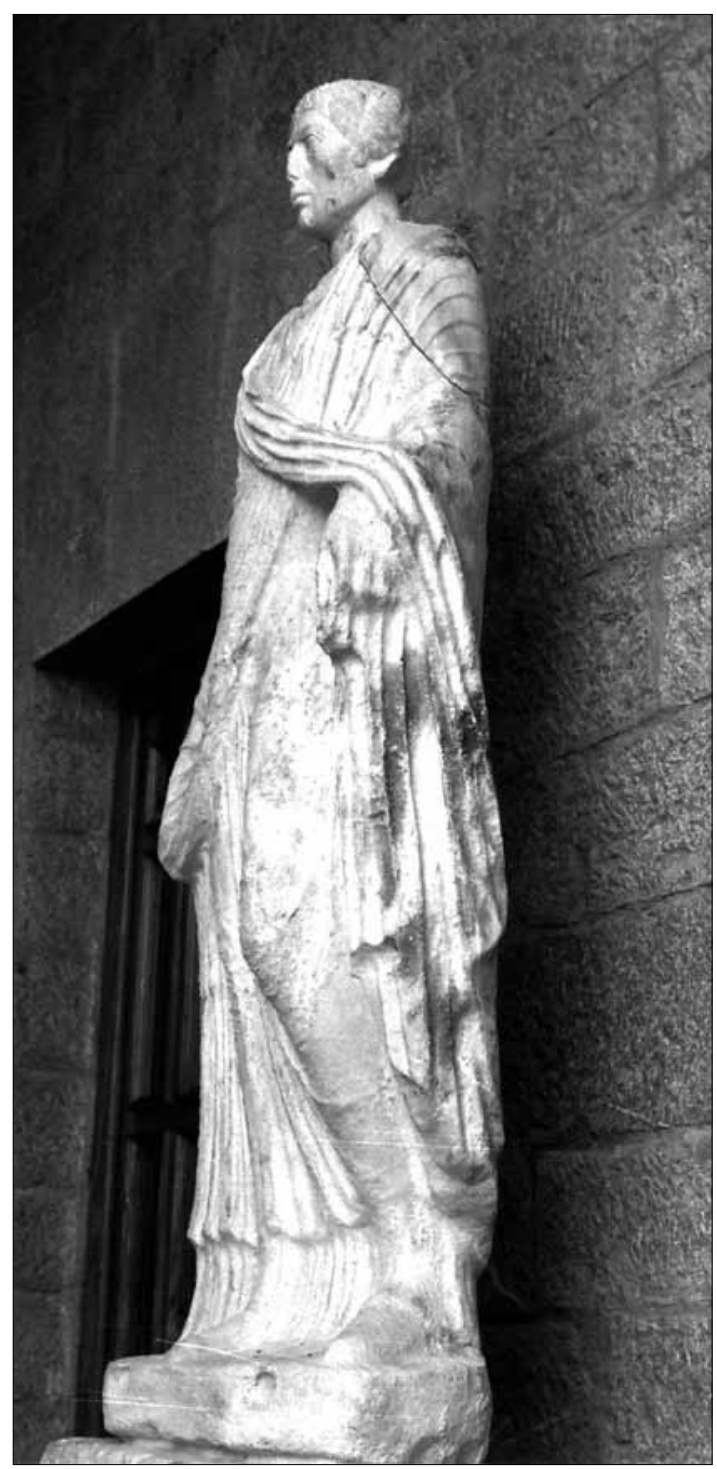

femenino en el patio central de Museo provincial de Jaén 


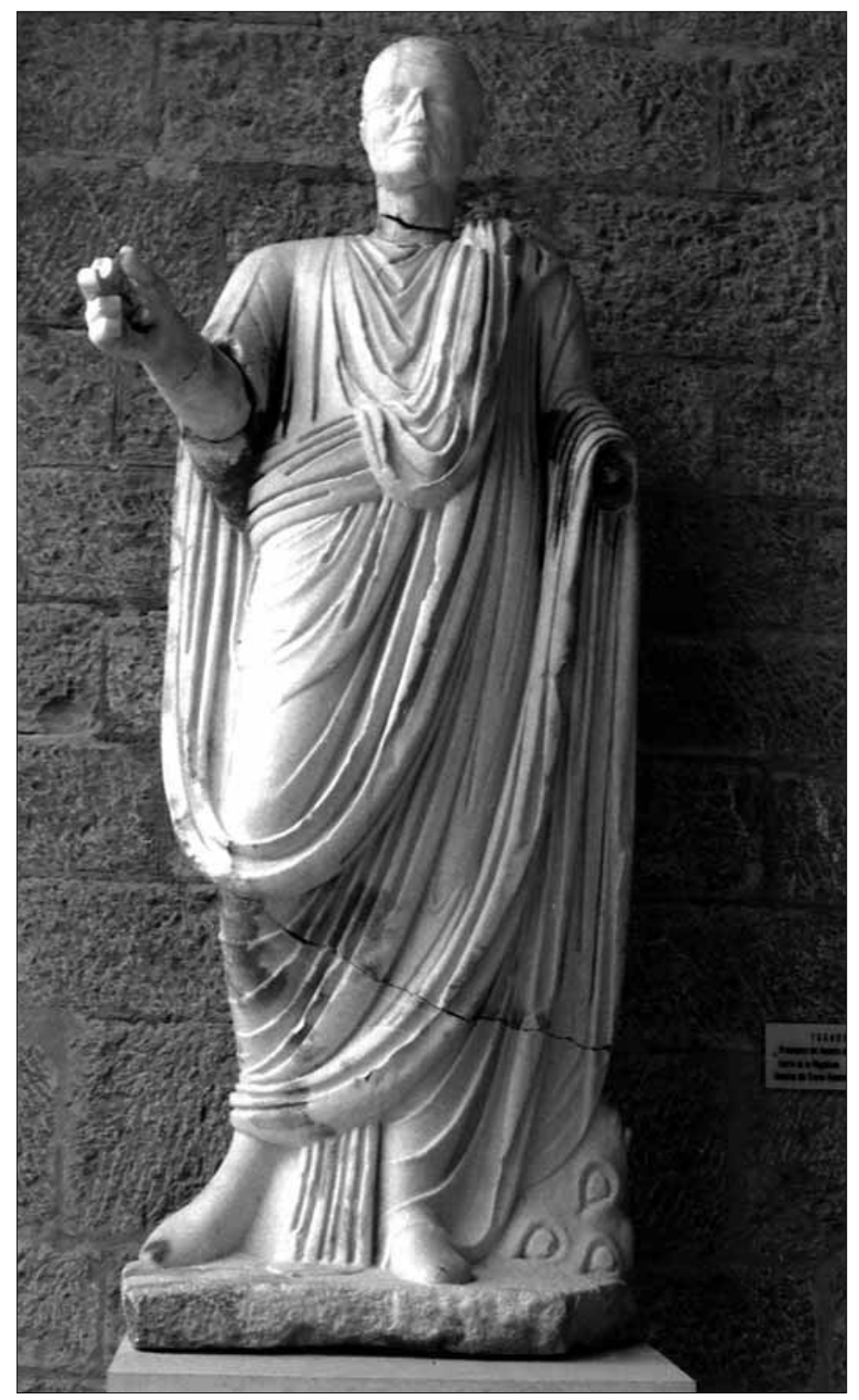

Lám. 21. La escultura del togado masculino en el patio central del Museo provincial de Jaén

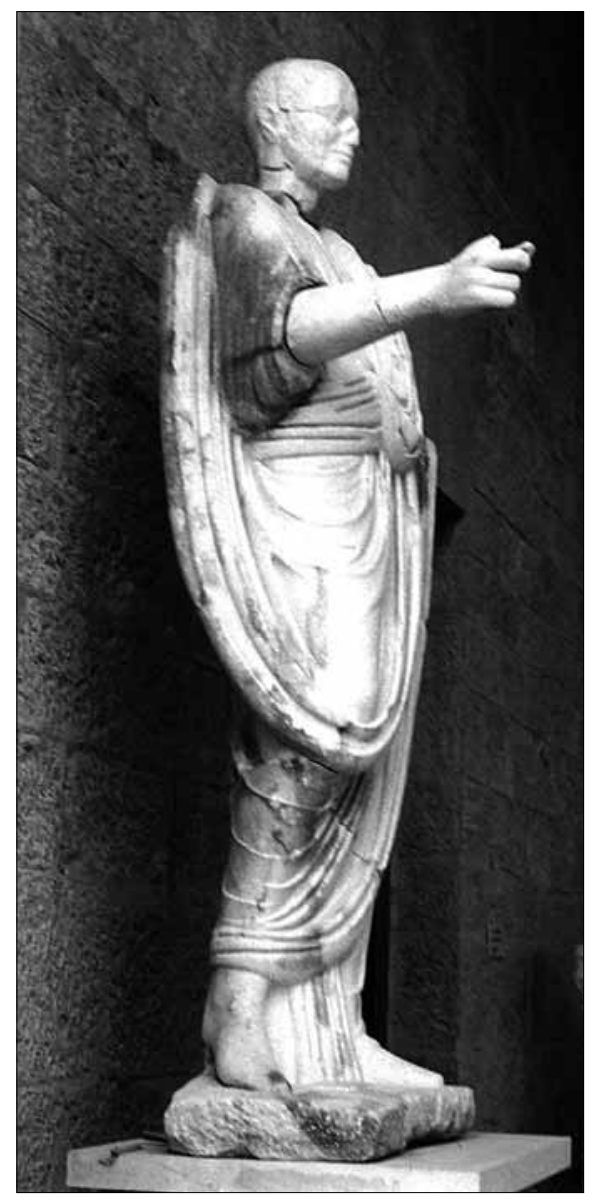

Lám. 22. La escultura del togado masculino en el patio central del Museo provincial de Jaén 


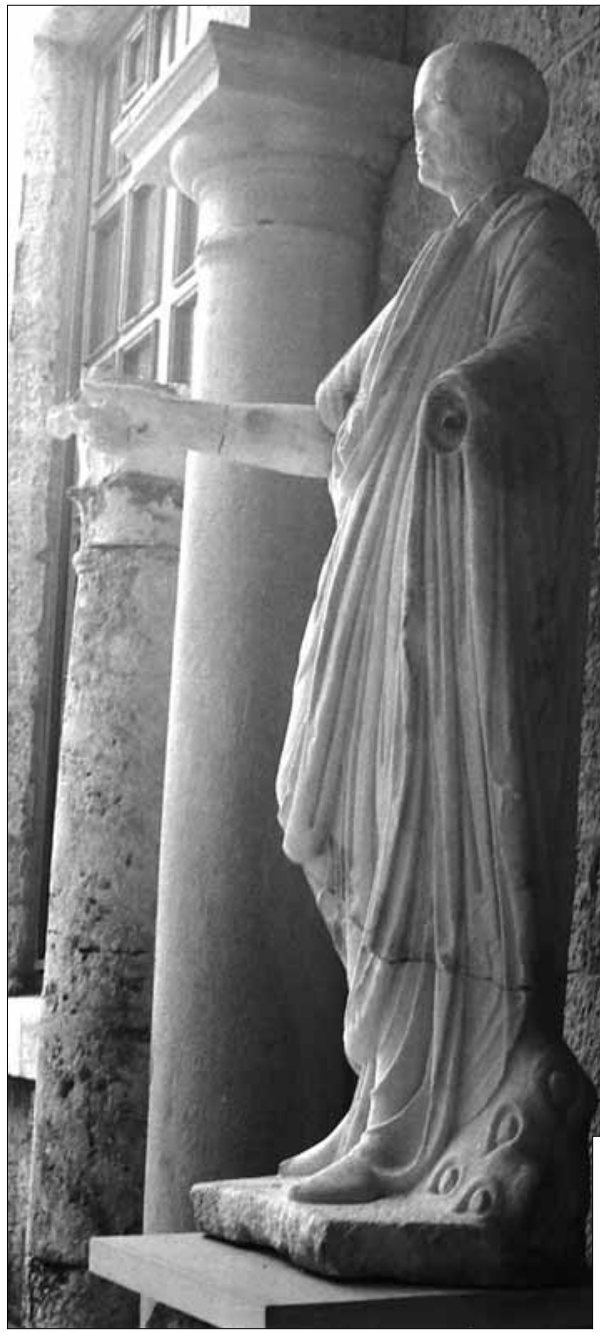

Lám. 23. La escultura del togado masculino en el patio central del Museo provincial de Jaén

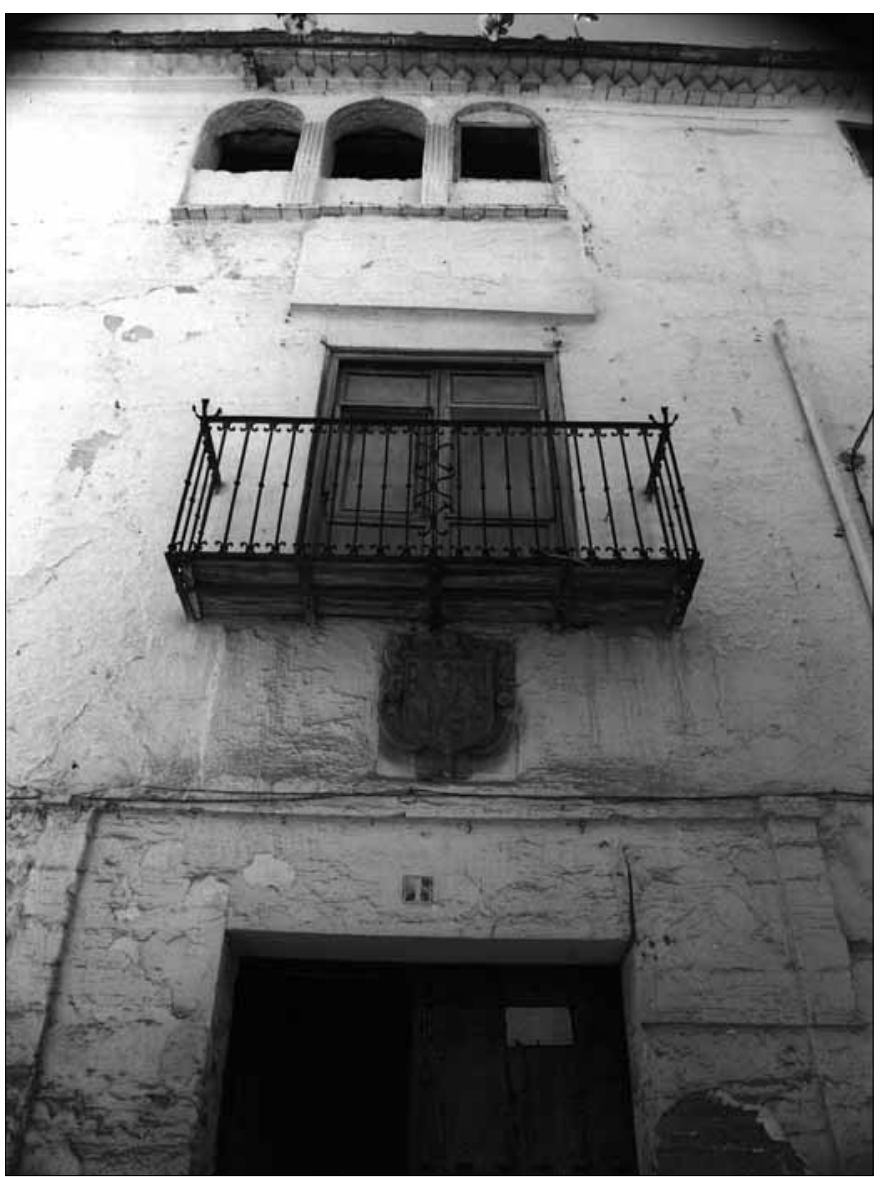

Lám. 24. Detalle del eje principa de la fachada a la calle de Los Uribe 


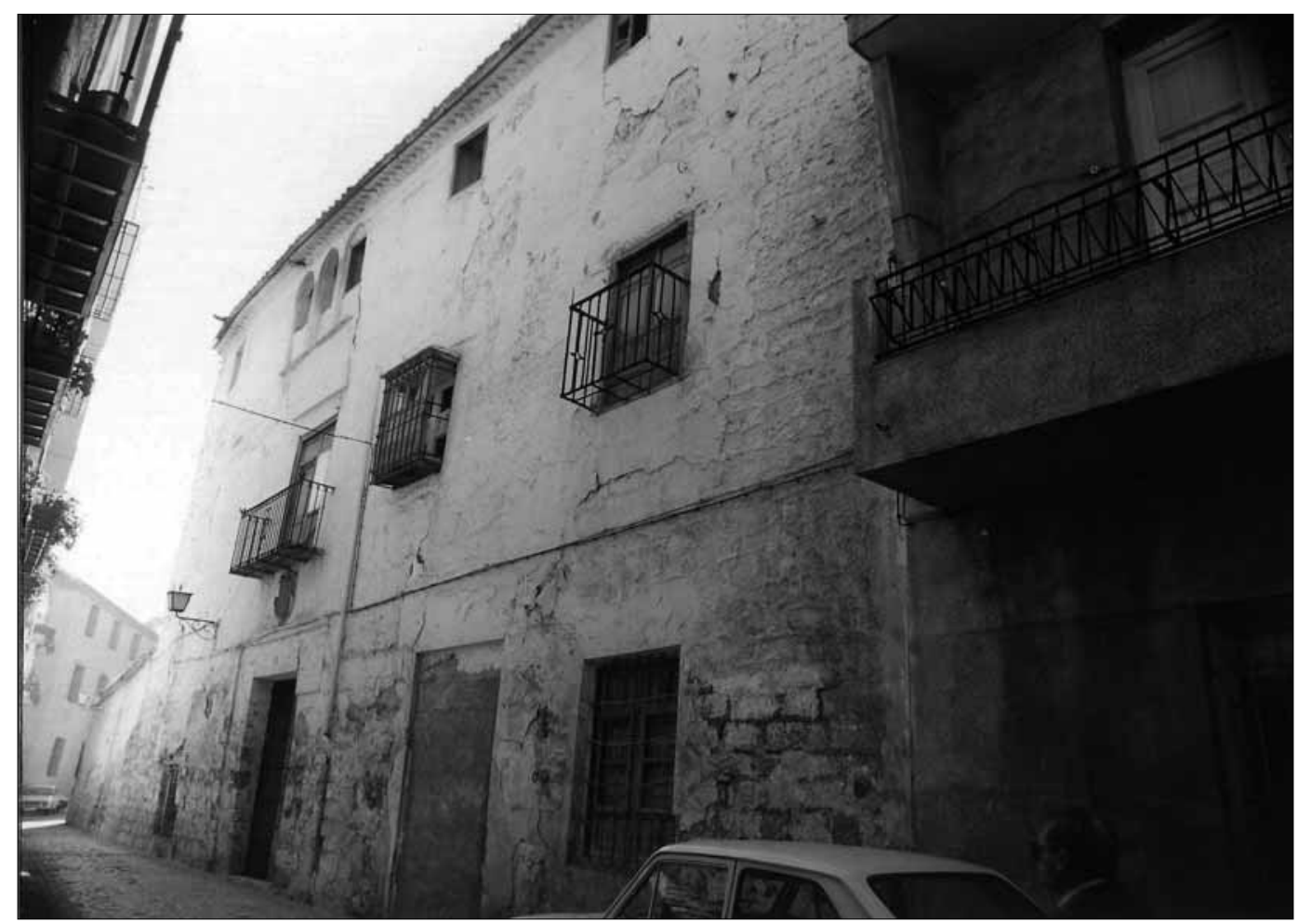

Lám. 25. Fachada principal de la casa $\mathrm{N} \cong 1$ a la calle de Los U ribe, hoy Santo Domingo Bajo, antes de su demolición. En primer término la fachada de la casa № 3 "modernizada".

Lám. 26. La puerta de entrada con restos de la portada que la guarnecía

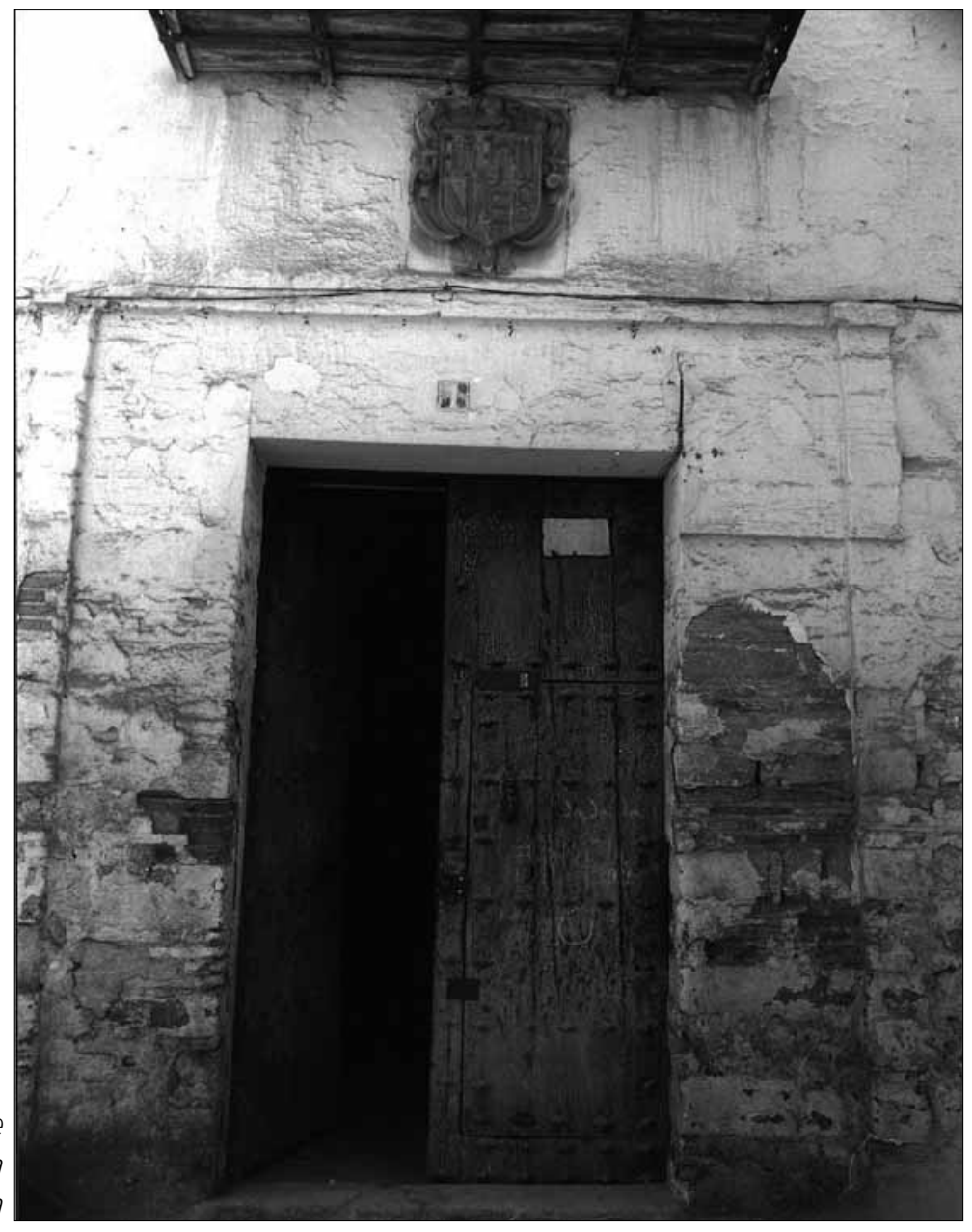




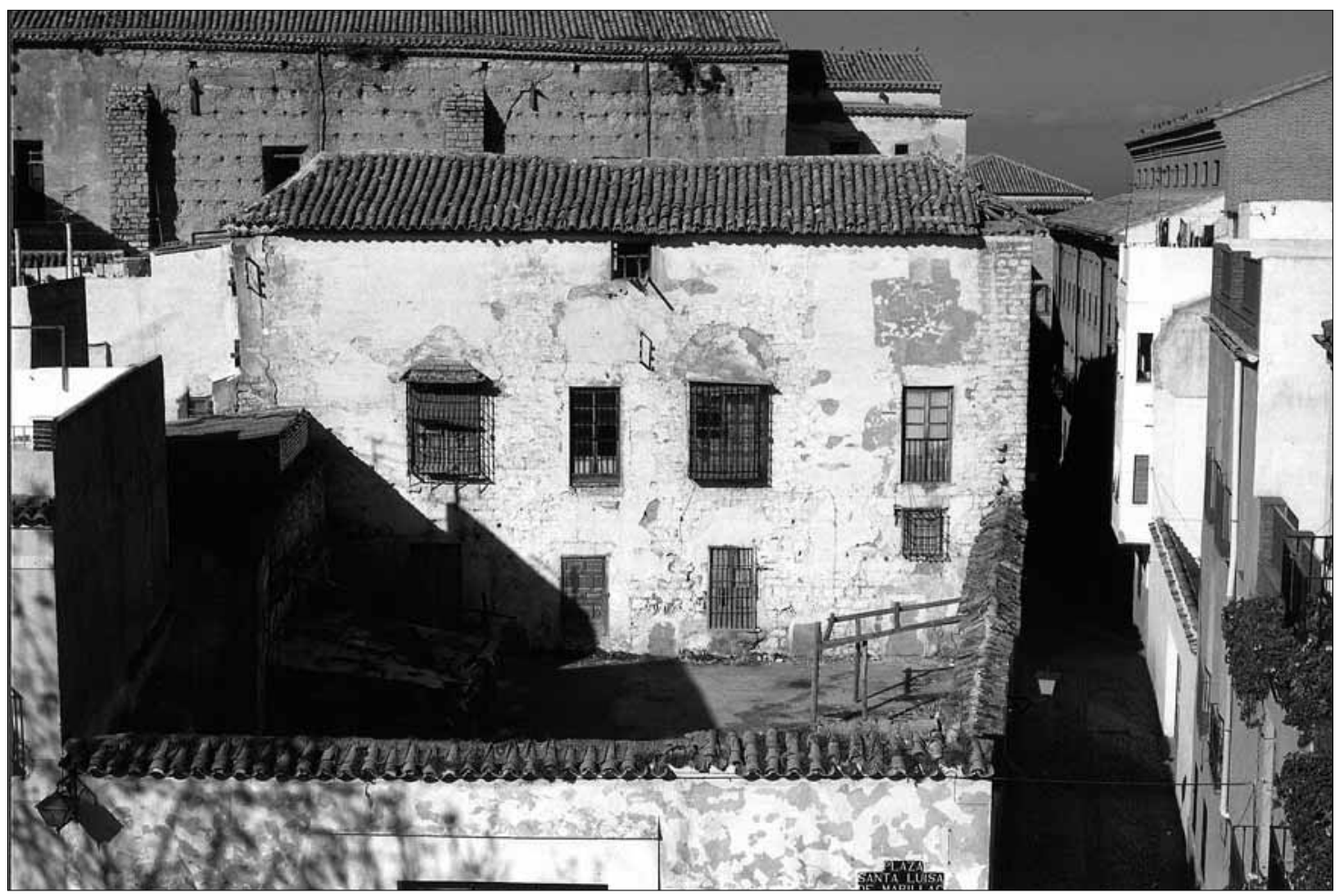

Lám. 27. Fachada interior de la casa № 1 al posible huerto

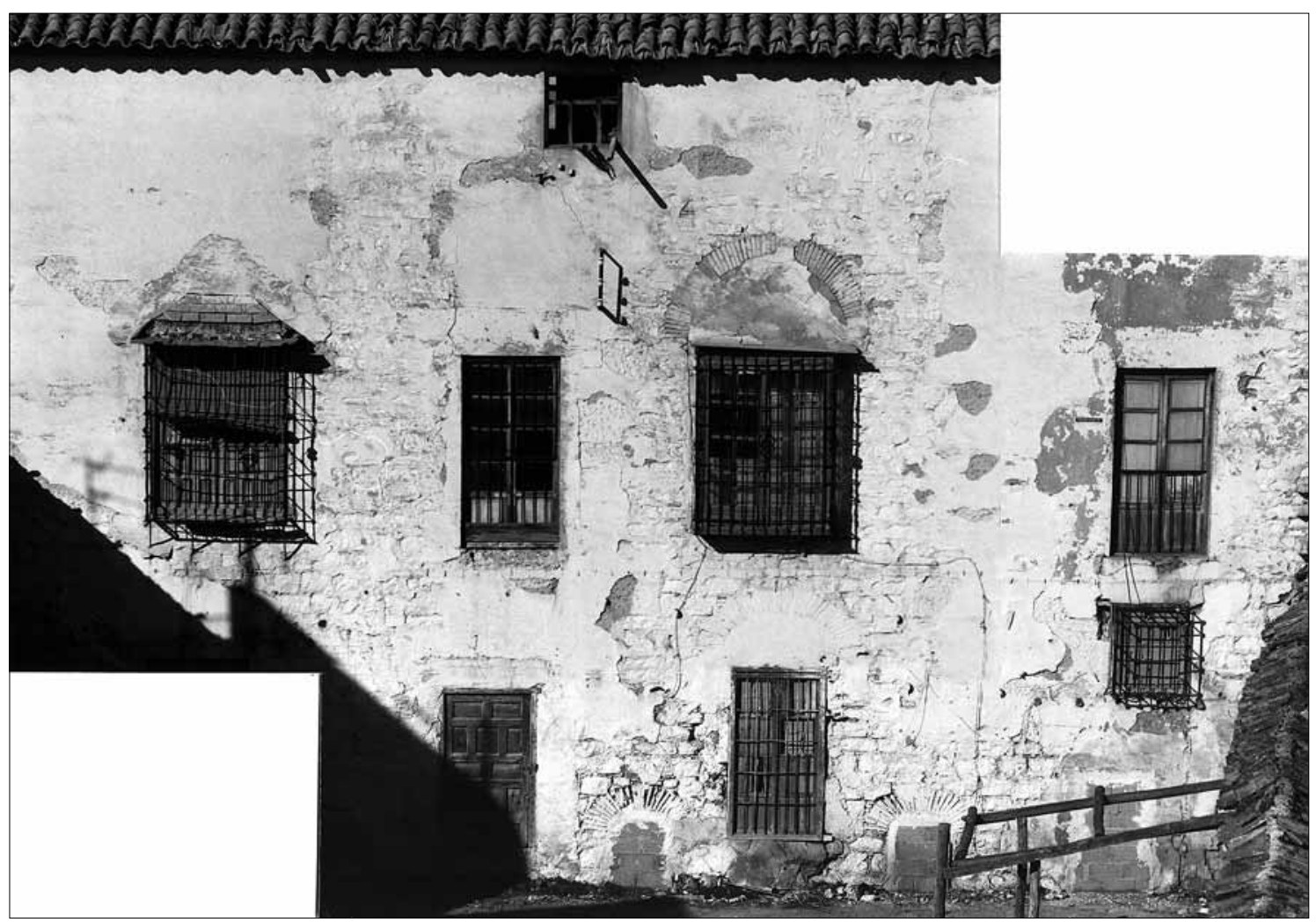

Lám. 28. Detalle de los huecos de la fachada anterior 


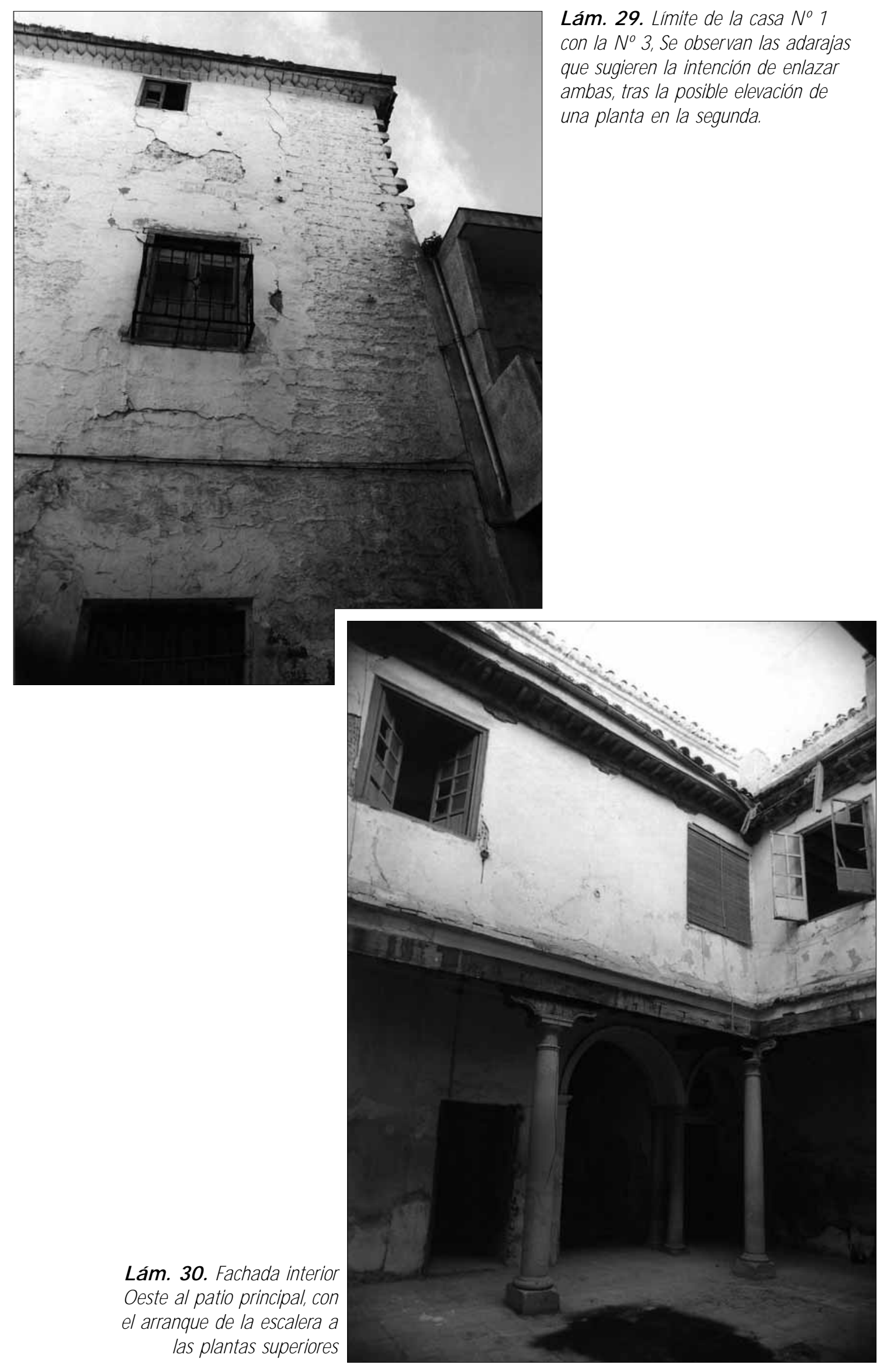




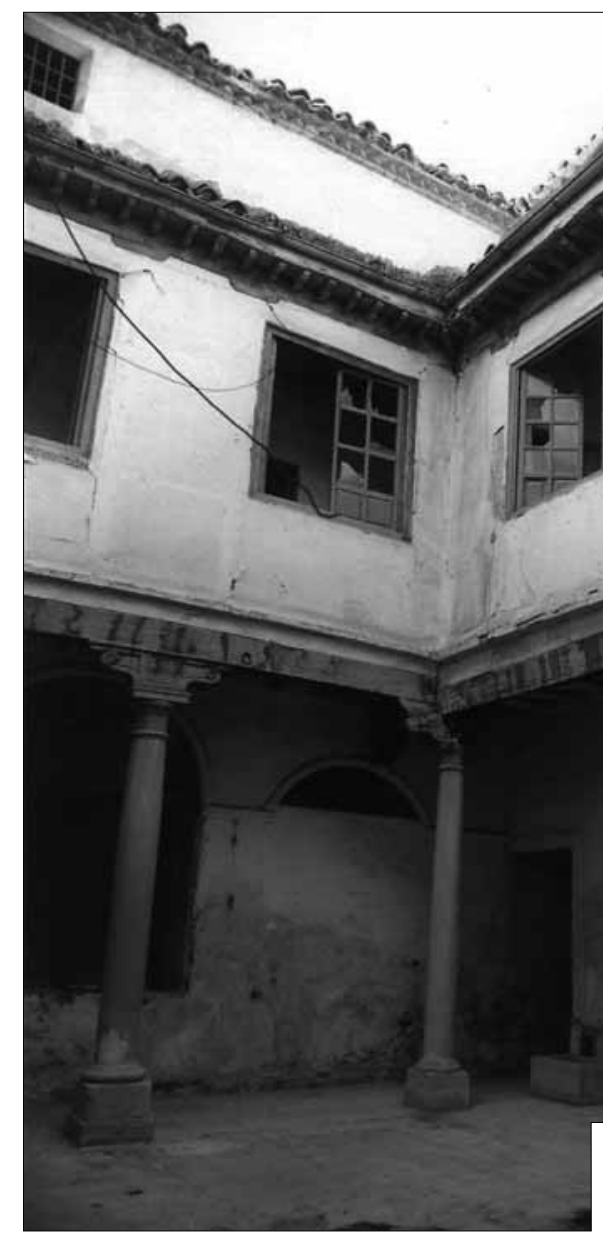

Lám. 31. Fachadas interiores

Oeste y Sur al patio principal

Lám. 32. Fachada interior Sur al patio principal

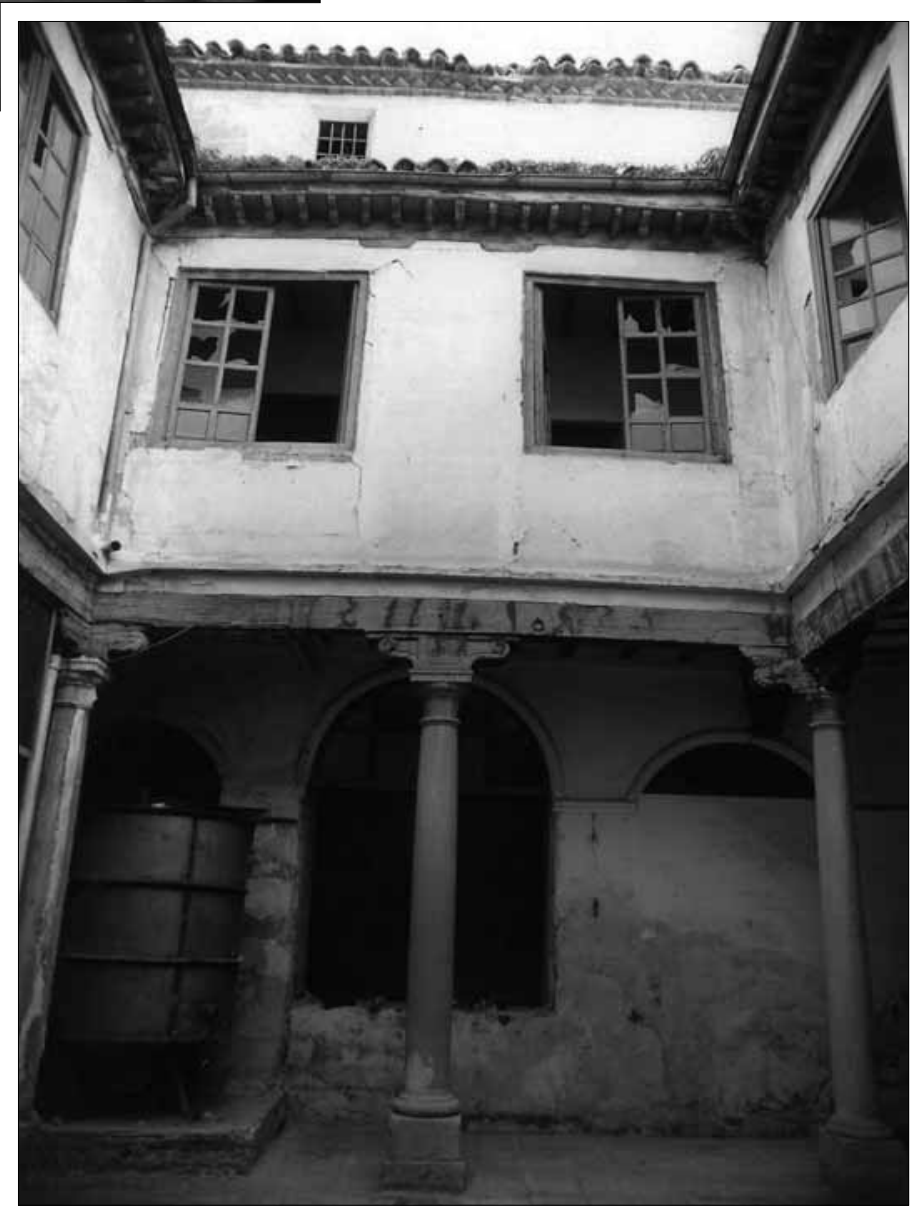




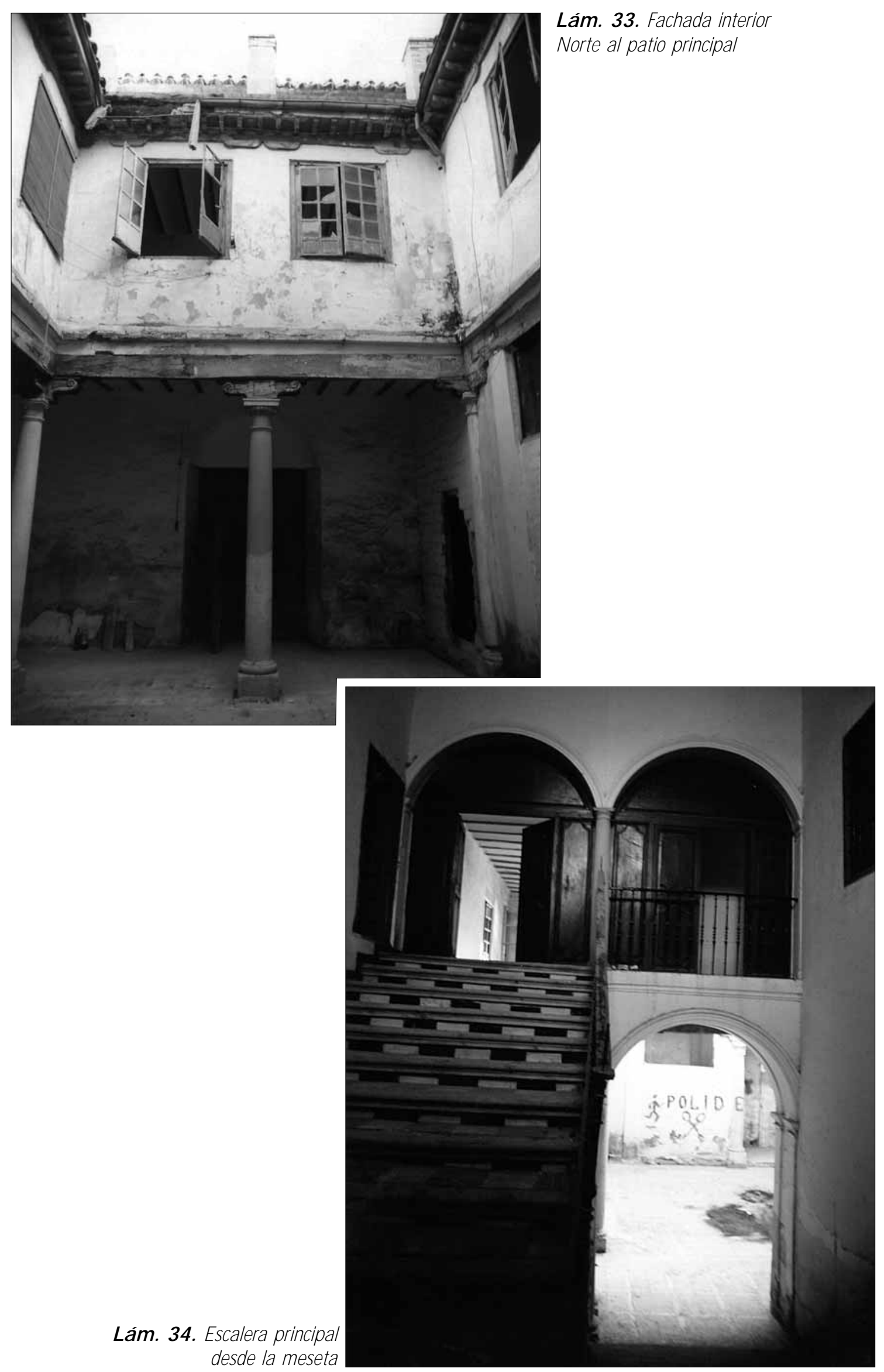




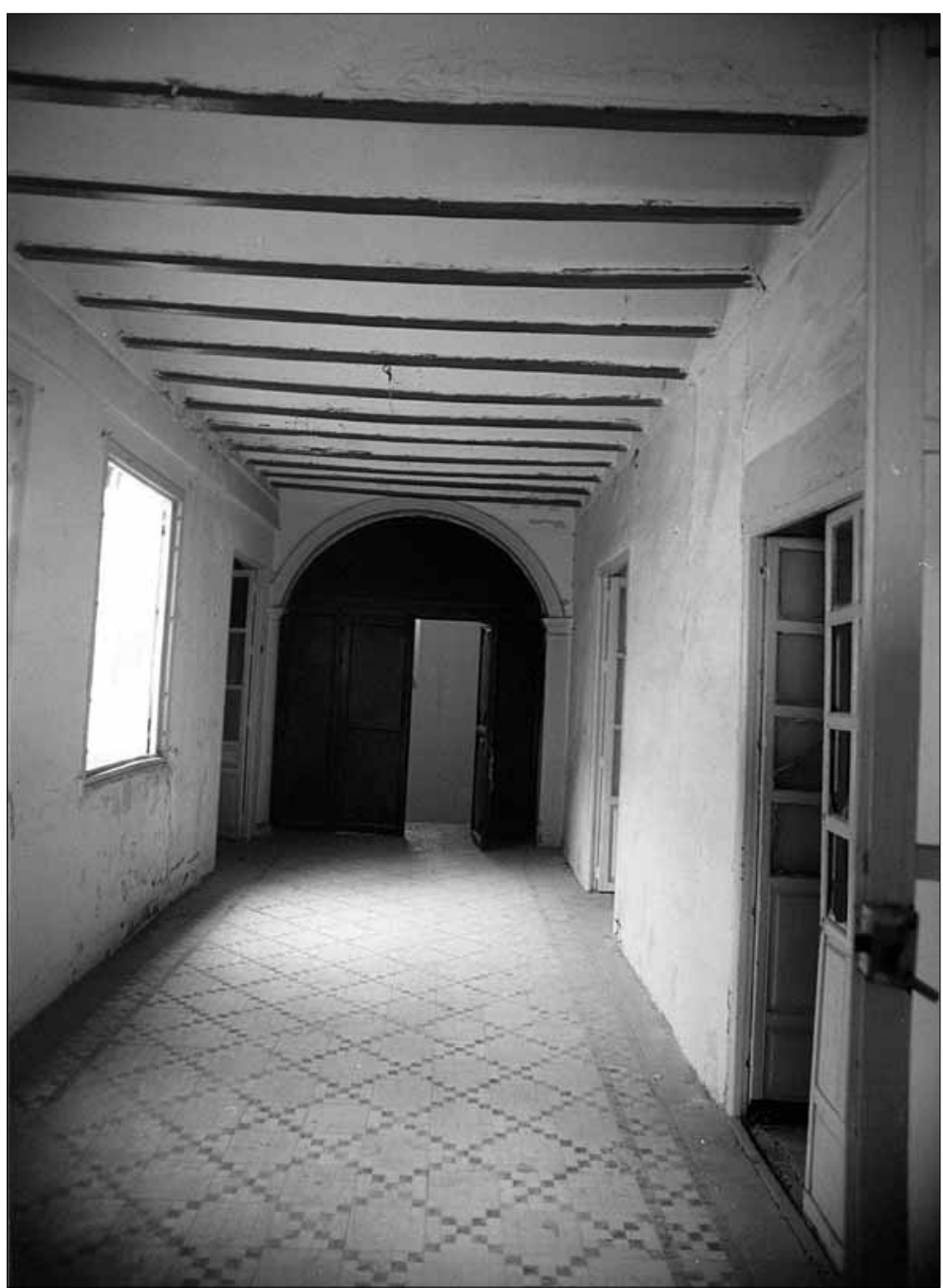

Lám. 35. Desembarco de la

escalera en la galería alta

Lám. 36. Detalle de la galería alta al patio principal (ángulo N oreste). Se observan las zapatas y pies derechos de madera, luego cegados.

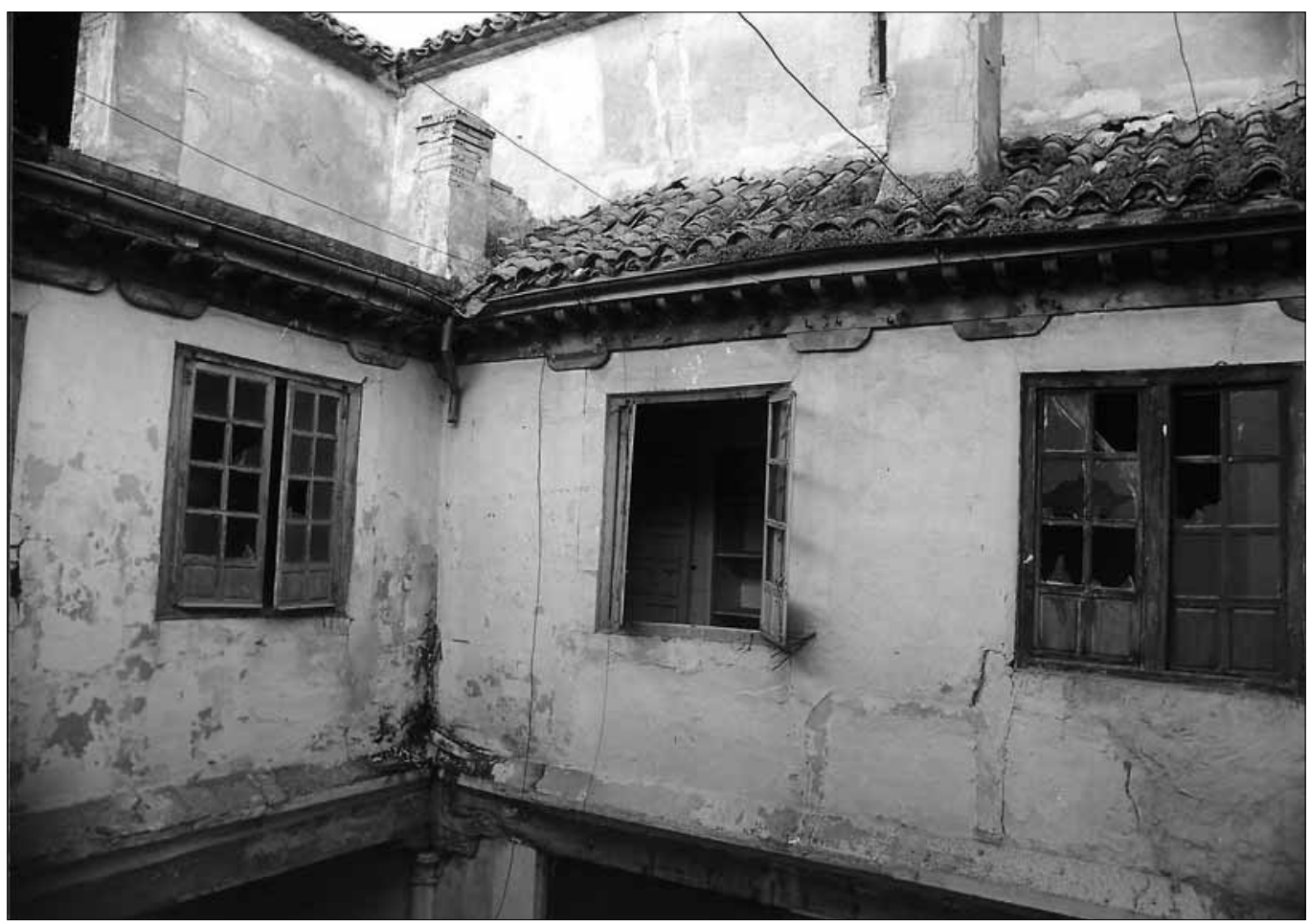




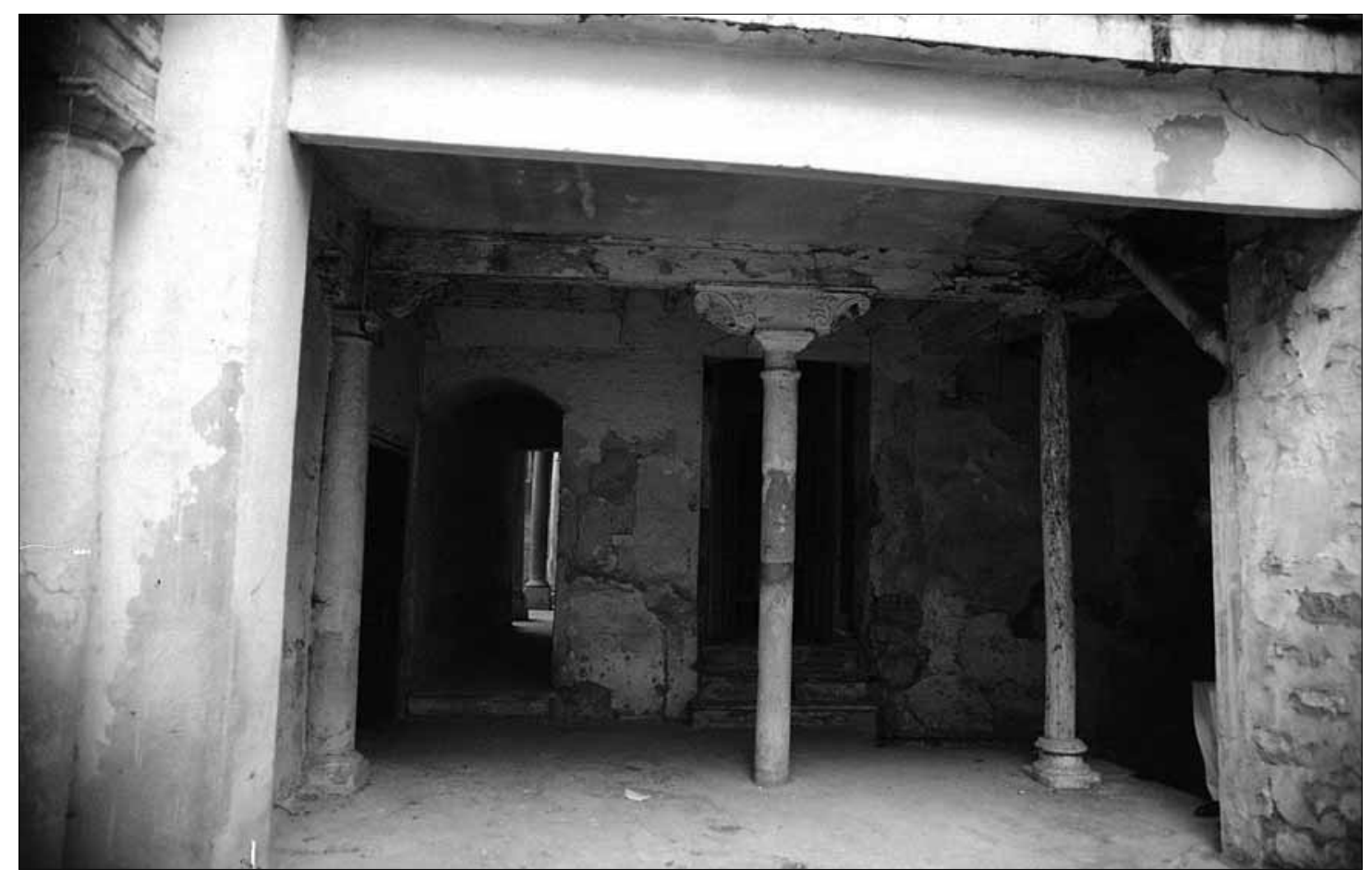

Lám. 37. Patio de servicio muy modificado. Lado Este

Lám. 38. Patio de

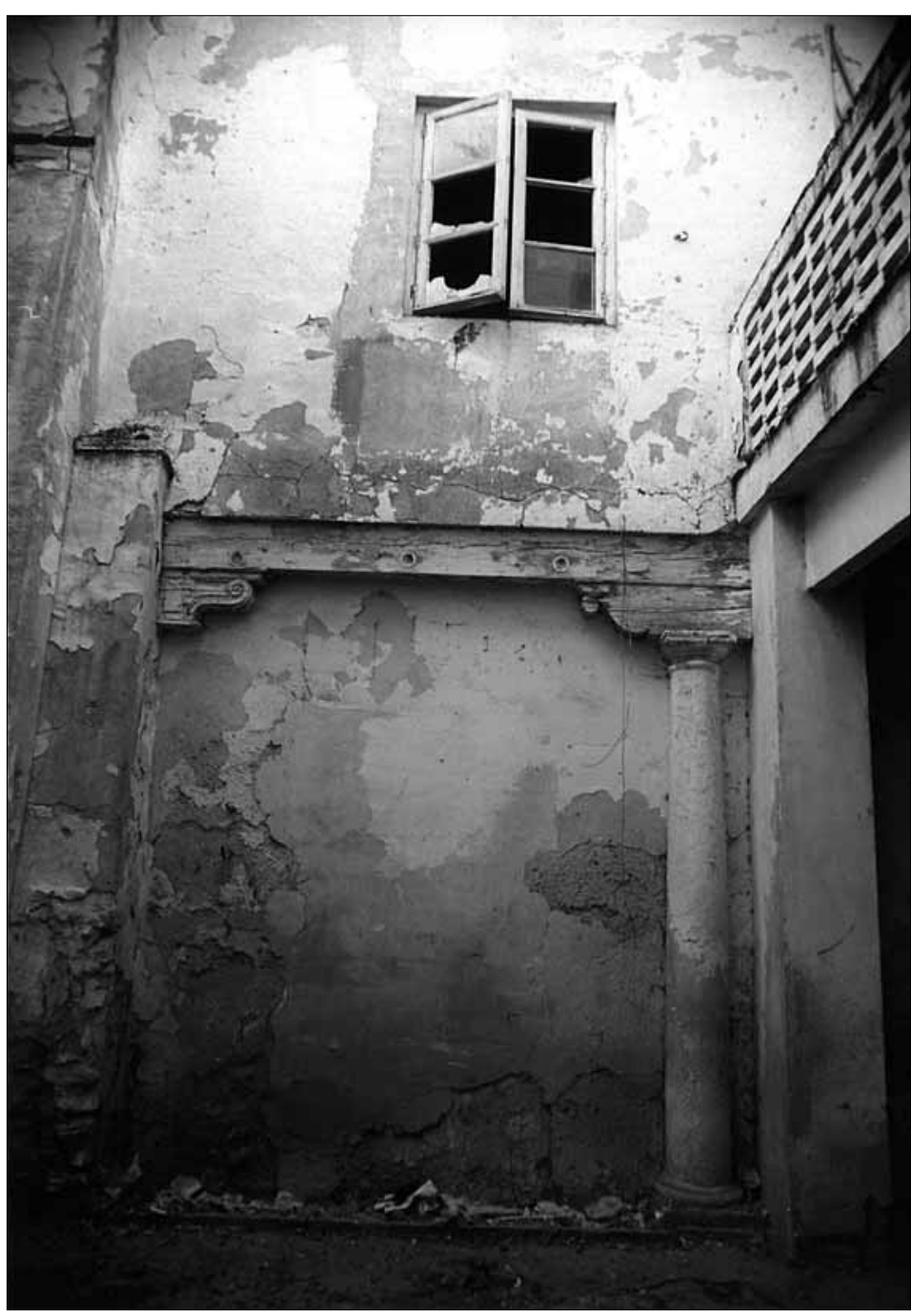
servicio. Lado Norte 


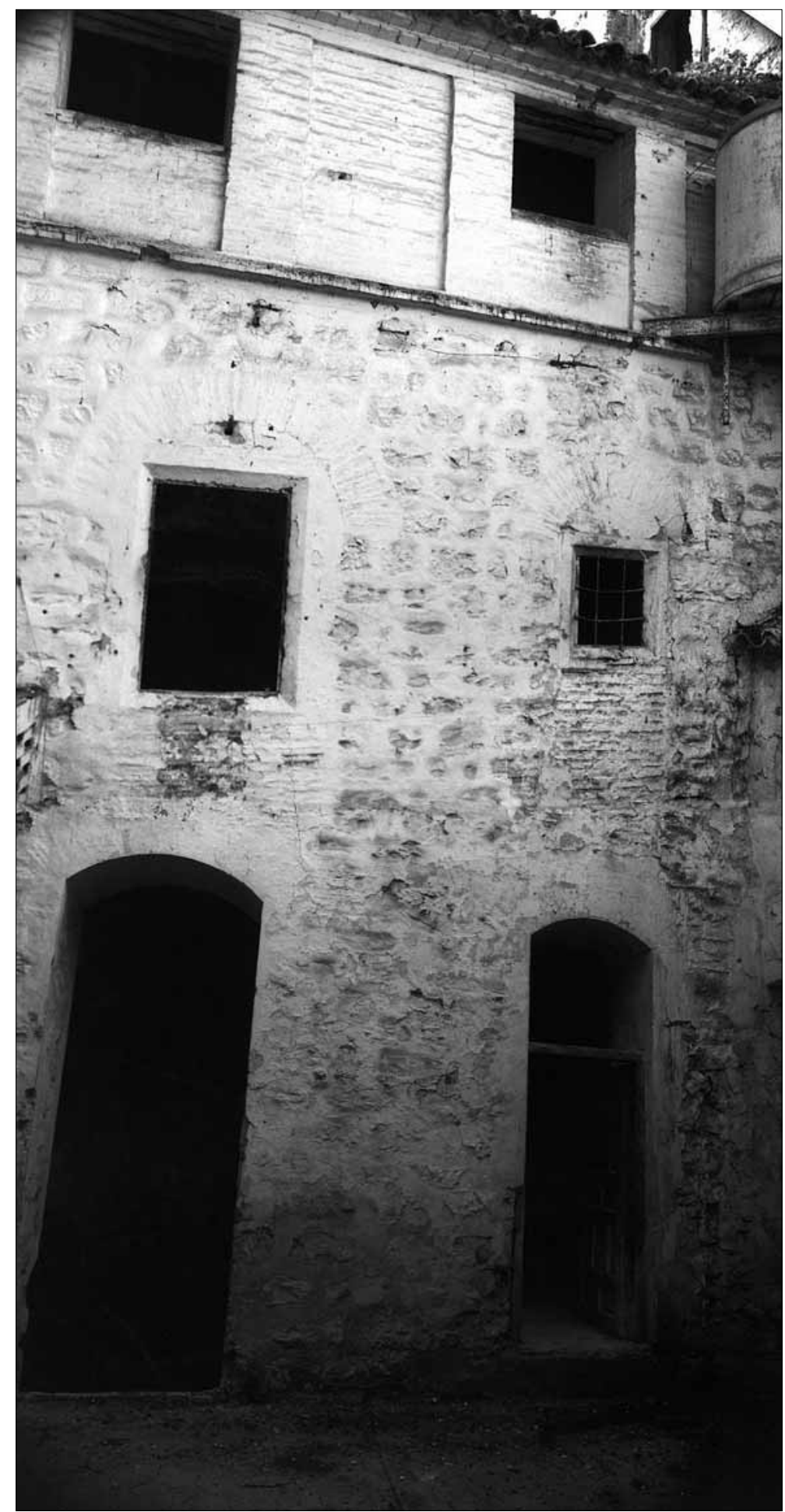

Lám. 39. Patio de servicio. Lado Sur 


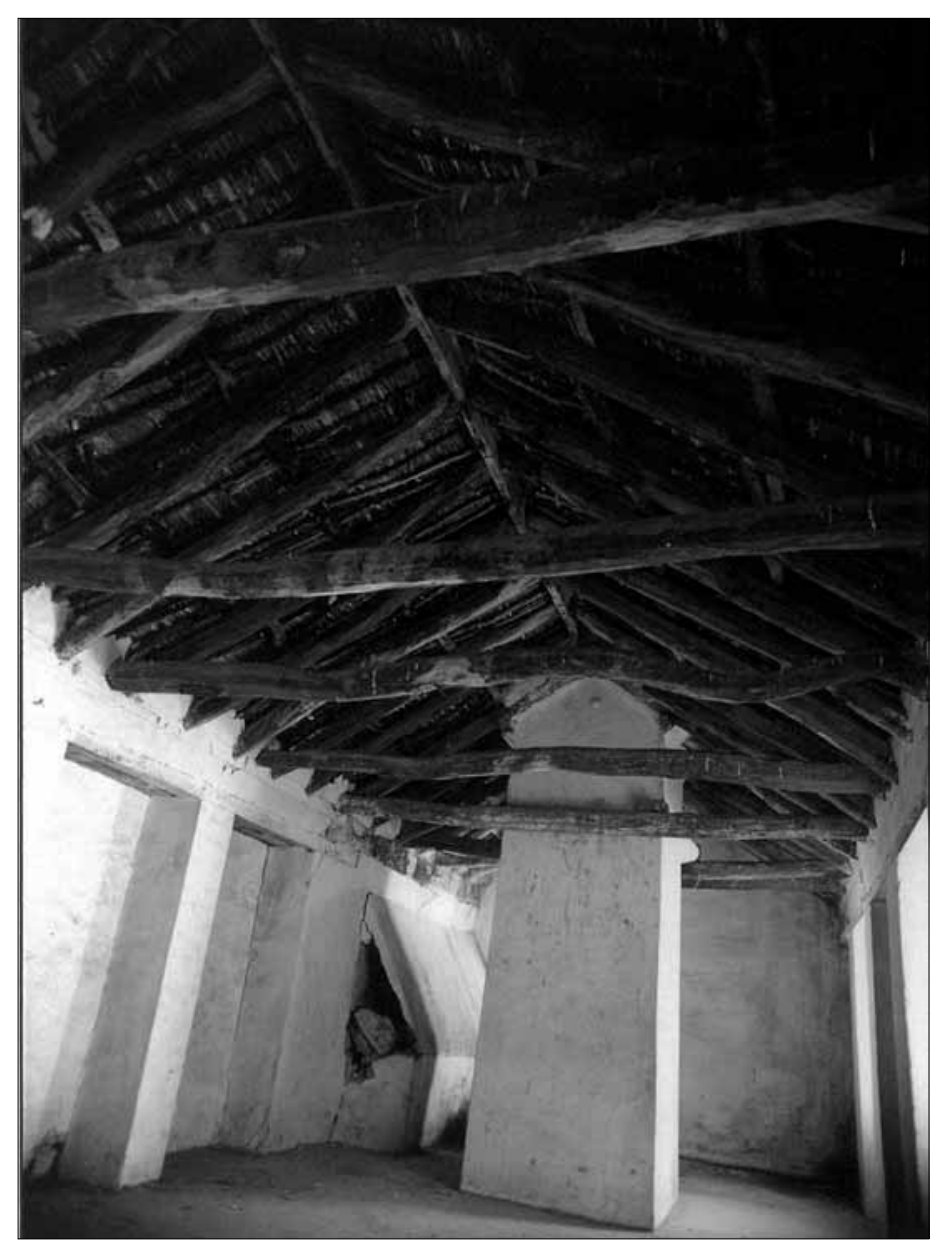

Lám. 40. Detalle de la cubierta

sobre las cámaras, resueltas con pares, nudillos, tirantes, cabios y cañizo bajo

la cubierta de teja árabe.

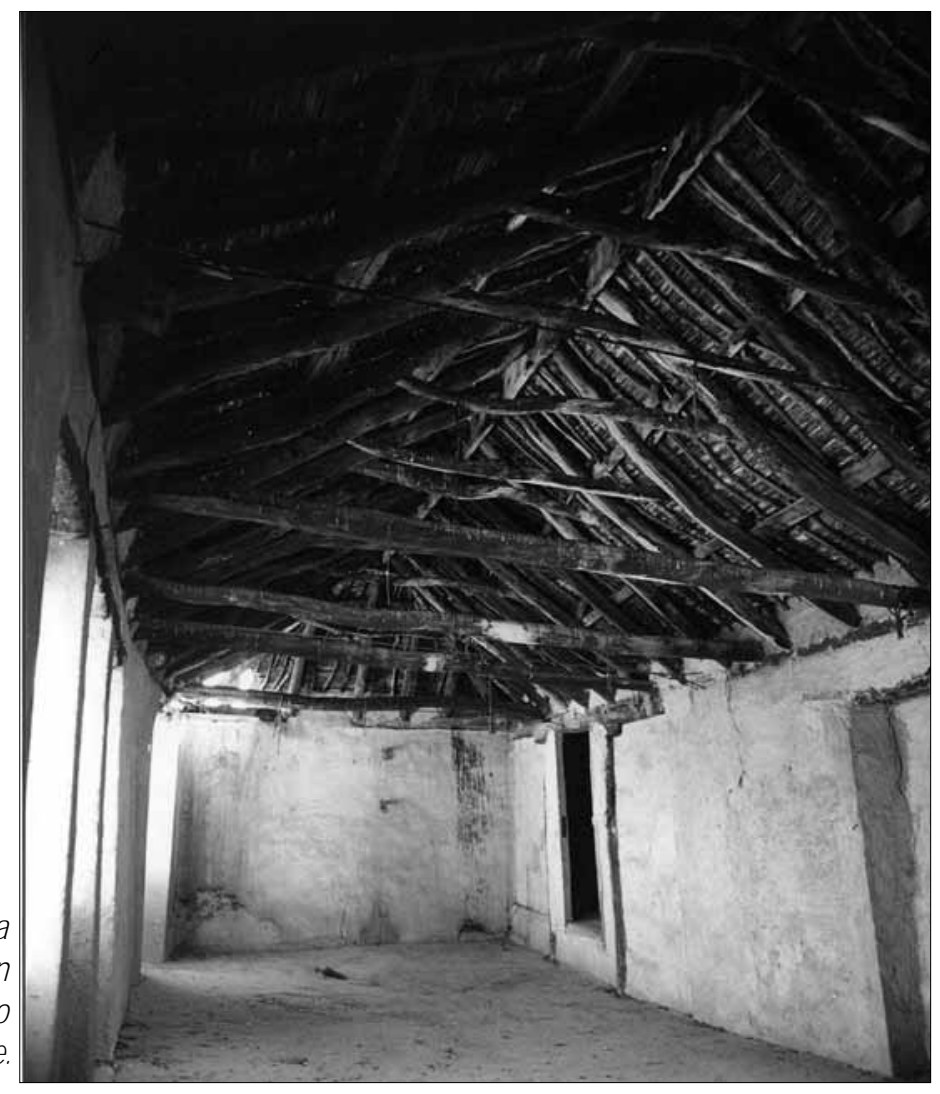

Lám. 41. Detalle de la cubierta sobre las cámaras, resueltas con pares, nudillos, tirantes, cabios y cañizo bajo la cubierta de teja árabe. 


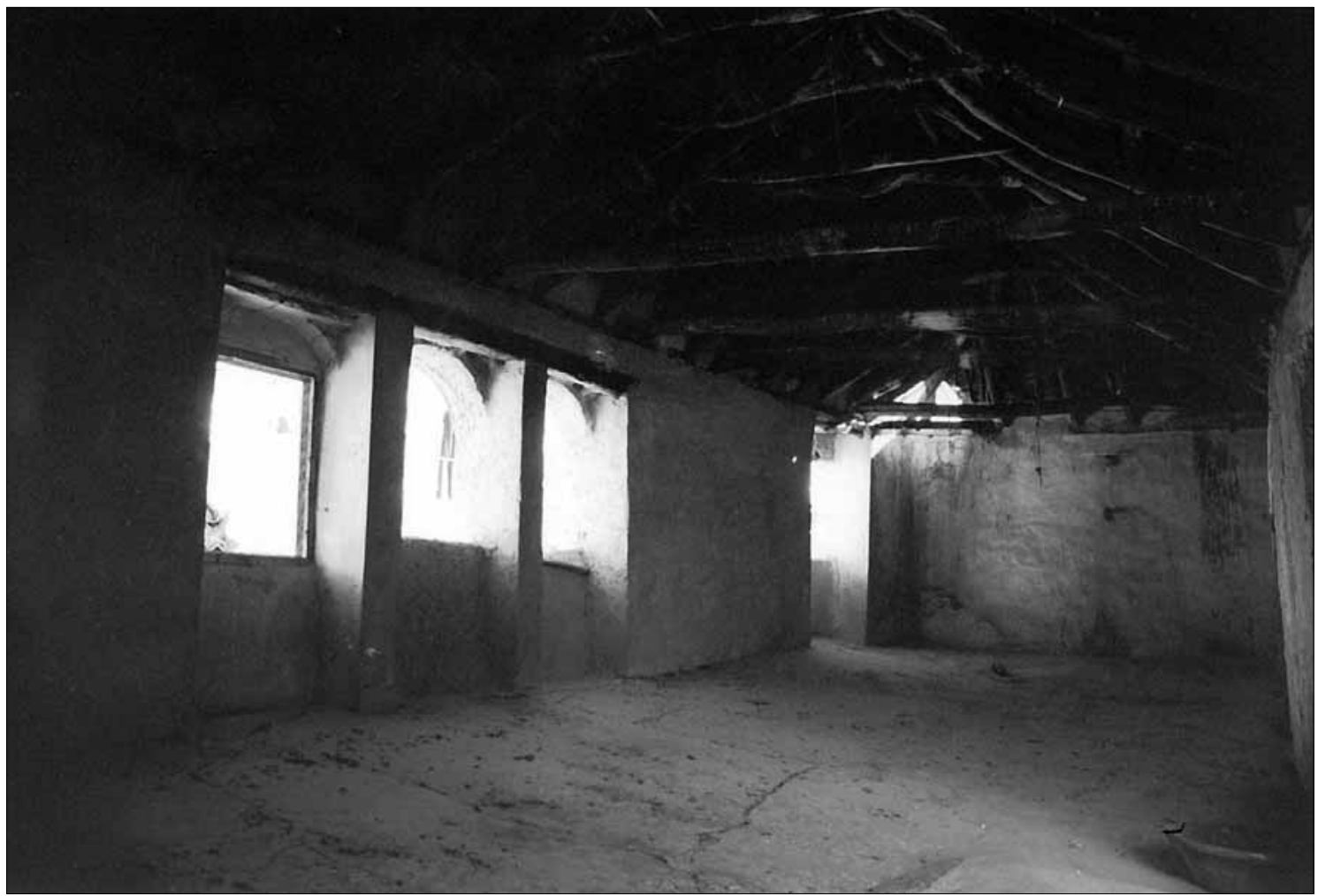

Lám. 42. detalle de la cubierta, con los tres huecos (arquillos) a fachada

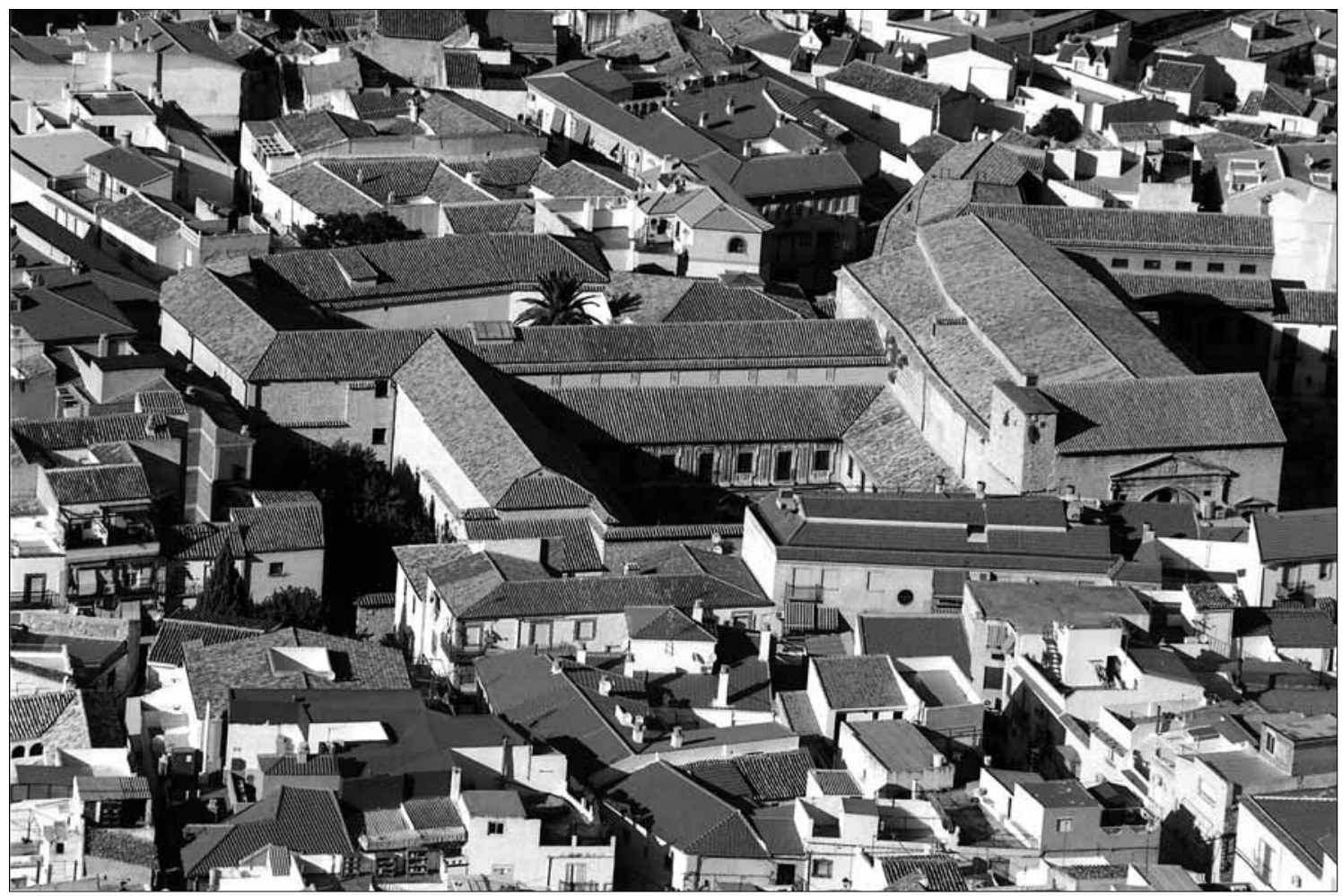

Lám. 43. Vista general del Archivo Histórico provincial, inmerso en el caserío el barrio de la Magdalena. 


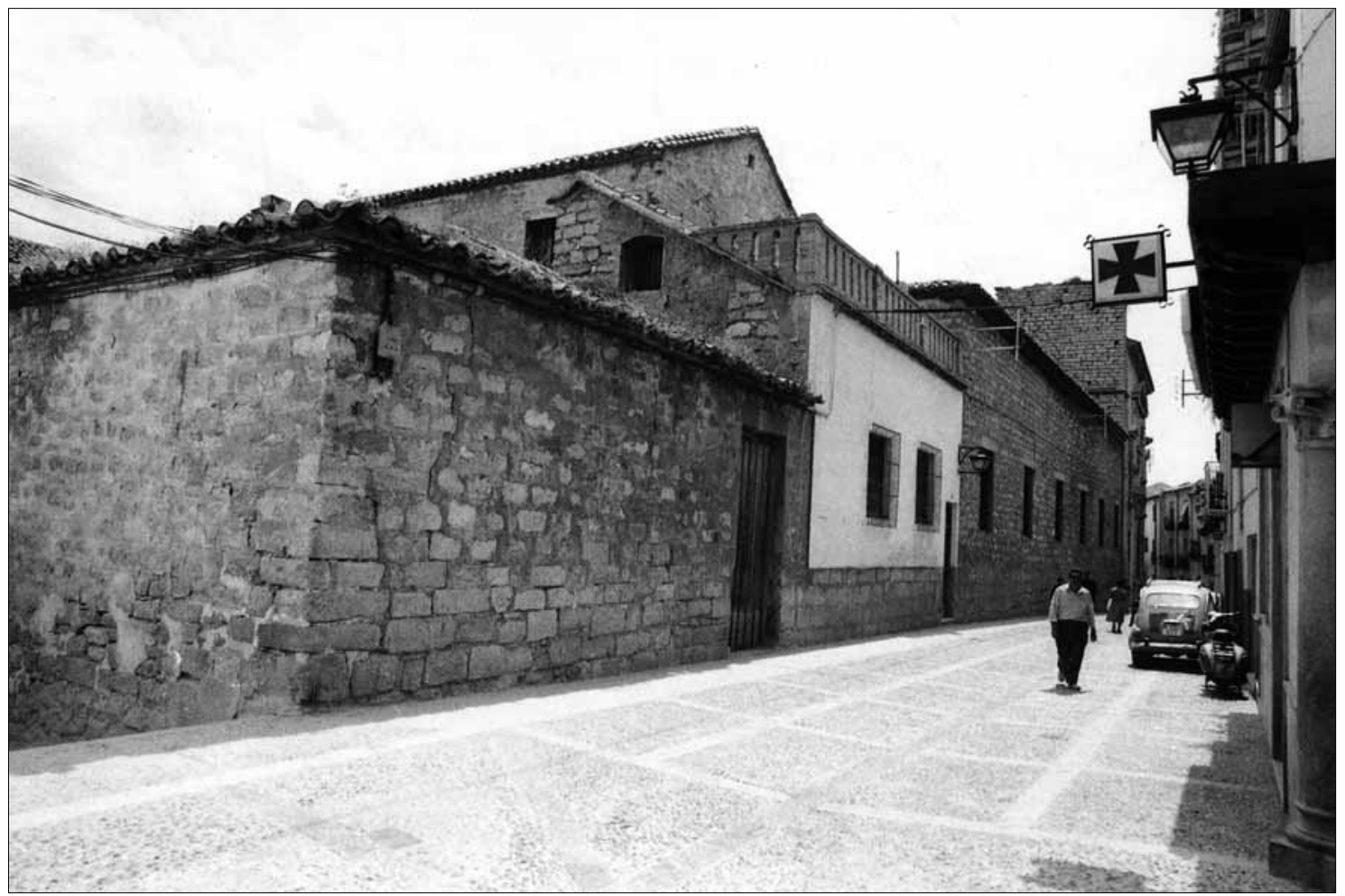

Lám. 44. Volúmenes del edificio y fachada a la calle Sto. Domingo, esquina a la calle Arquillos. 1979

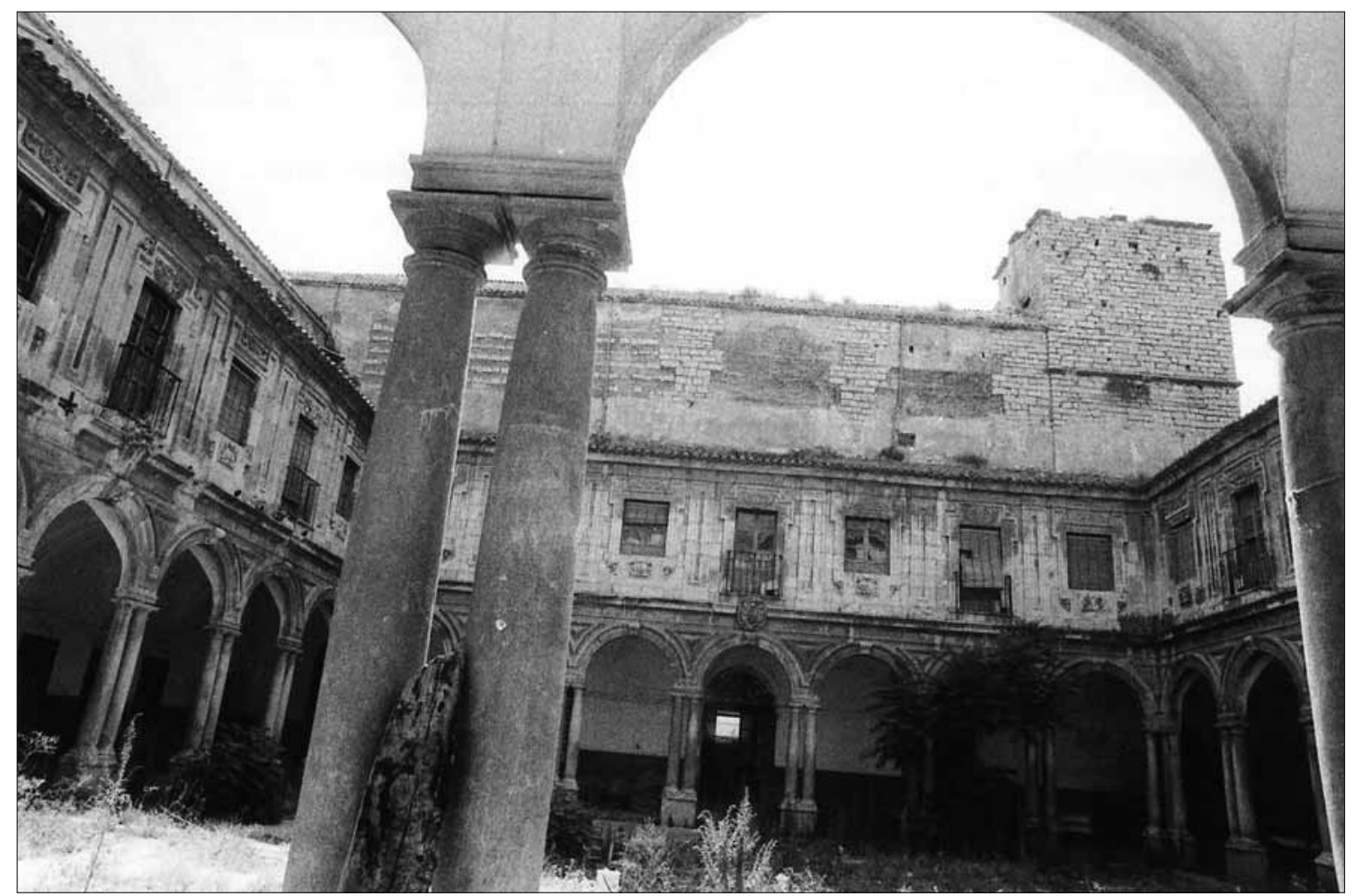

Lám. 45. Vista del claustro desde la galería inferior. 1979 


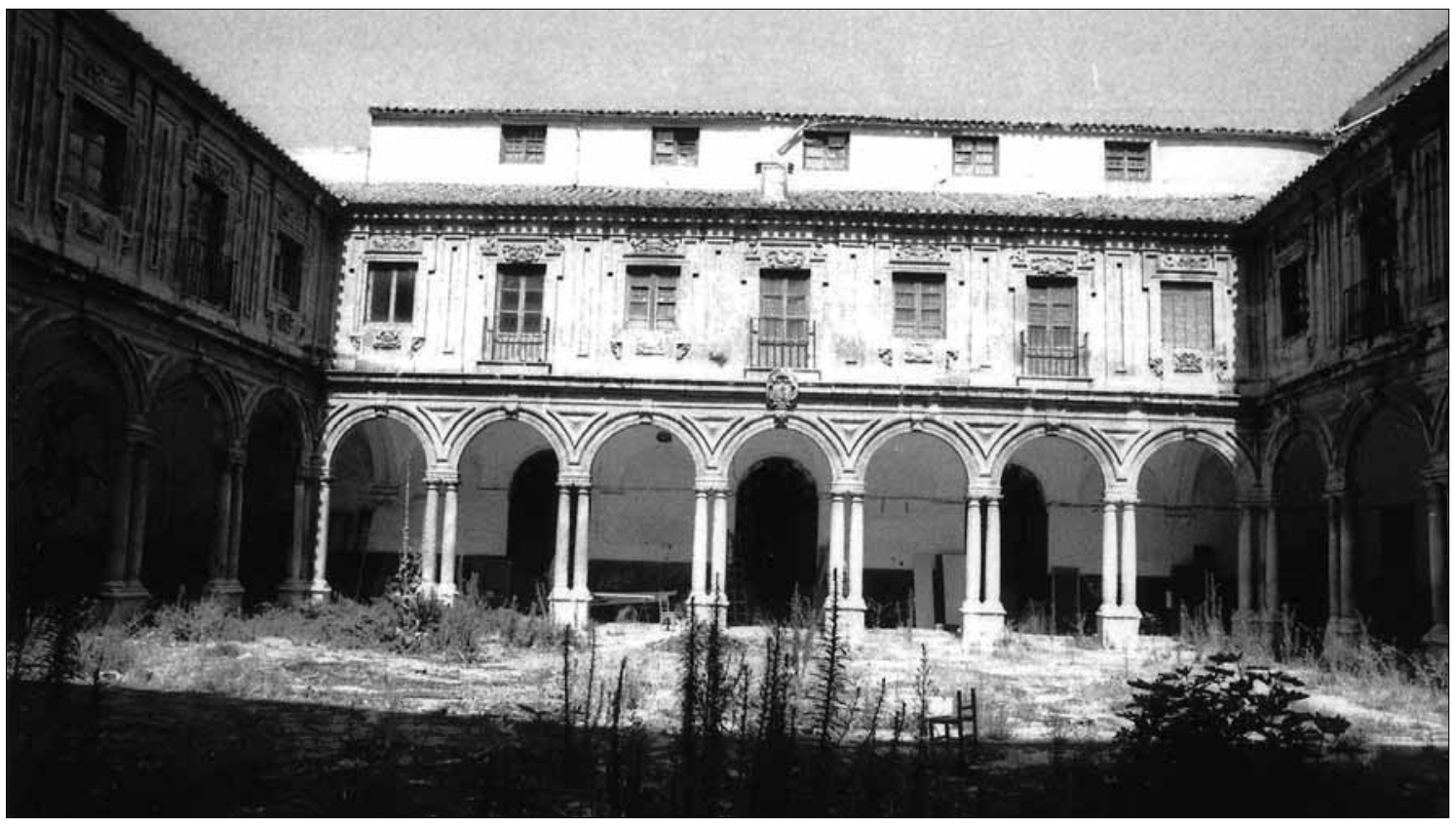

Lám. 46. Lado norte del Claustro. 1979

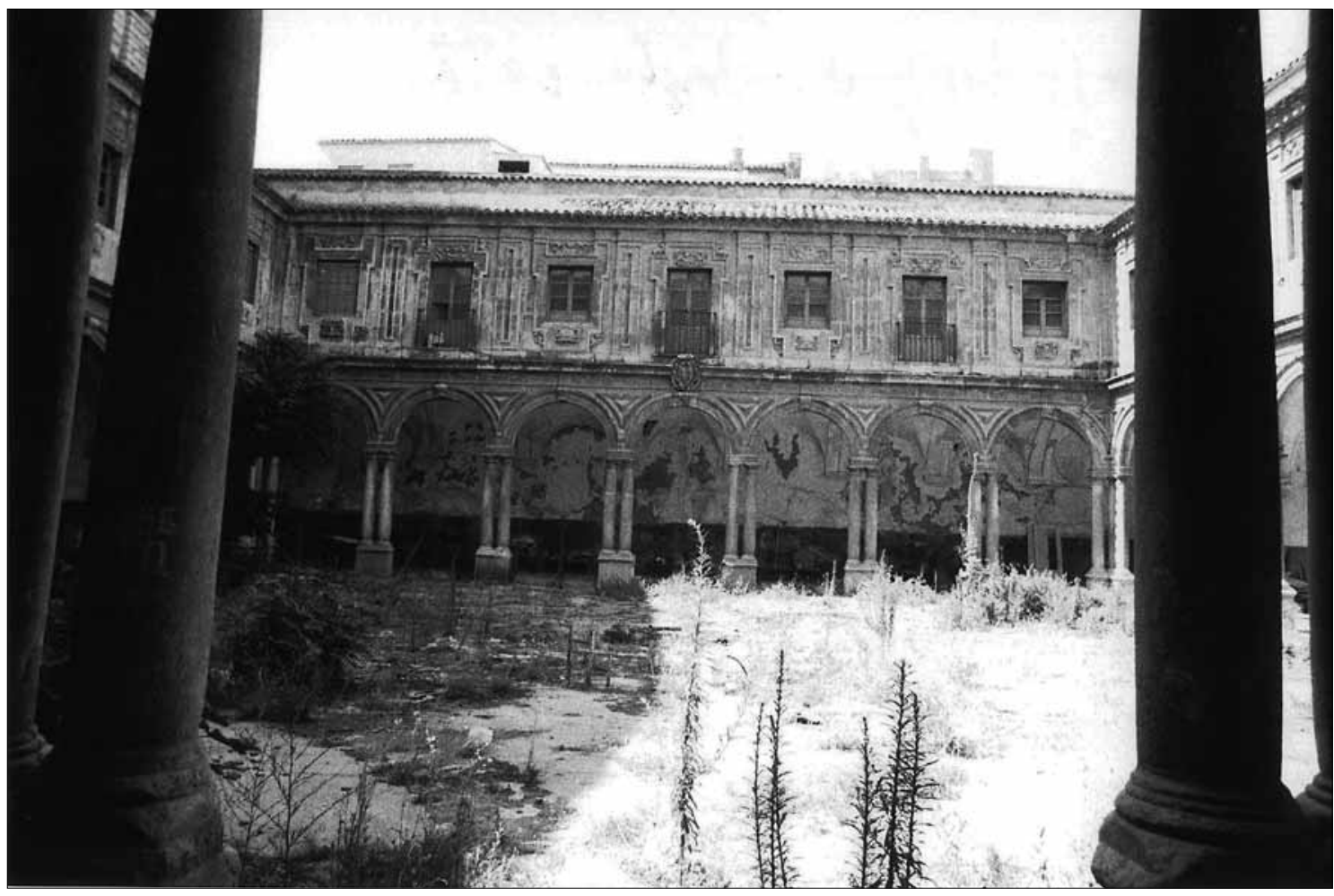

Lám. 47. Lado oeste del Claustro. 1979 


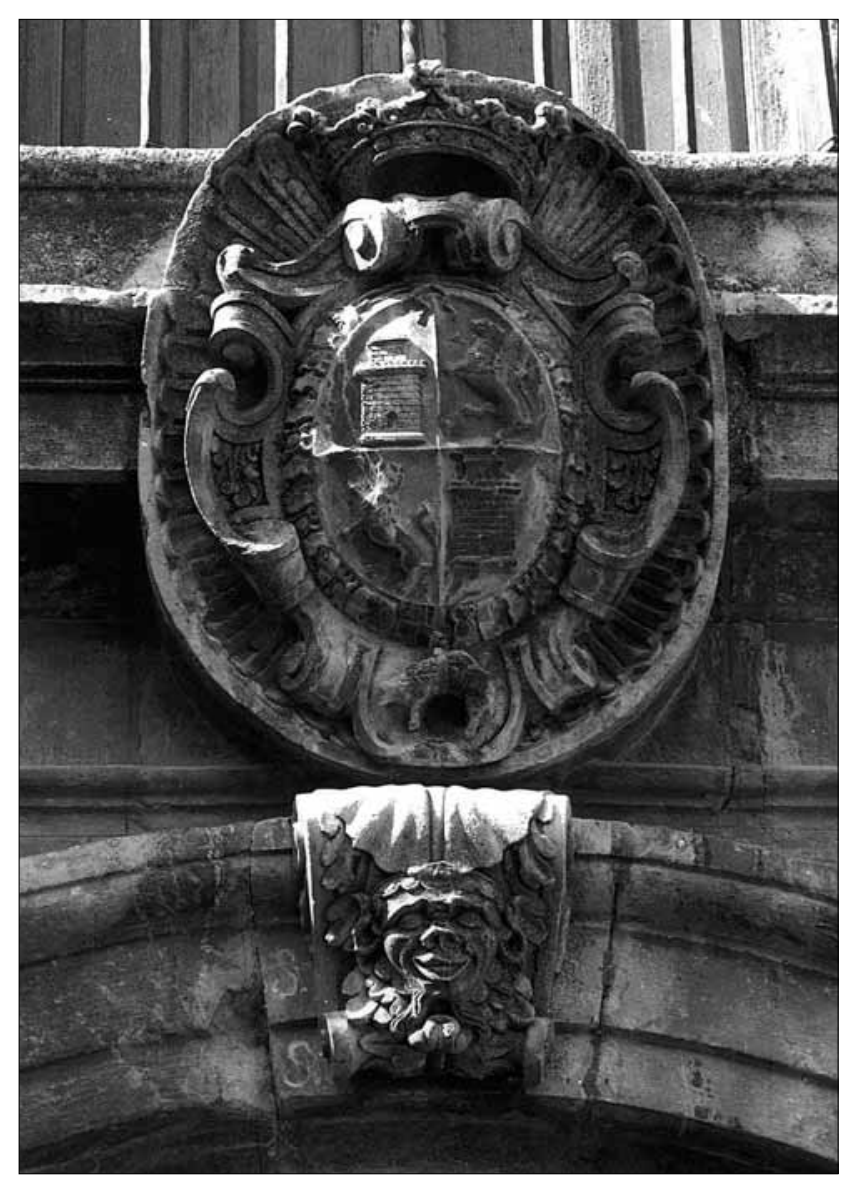

Lám. 48. Claustro. Escudo de armas de la Casa de Austria. 1979

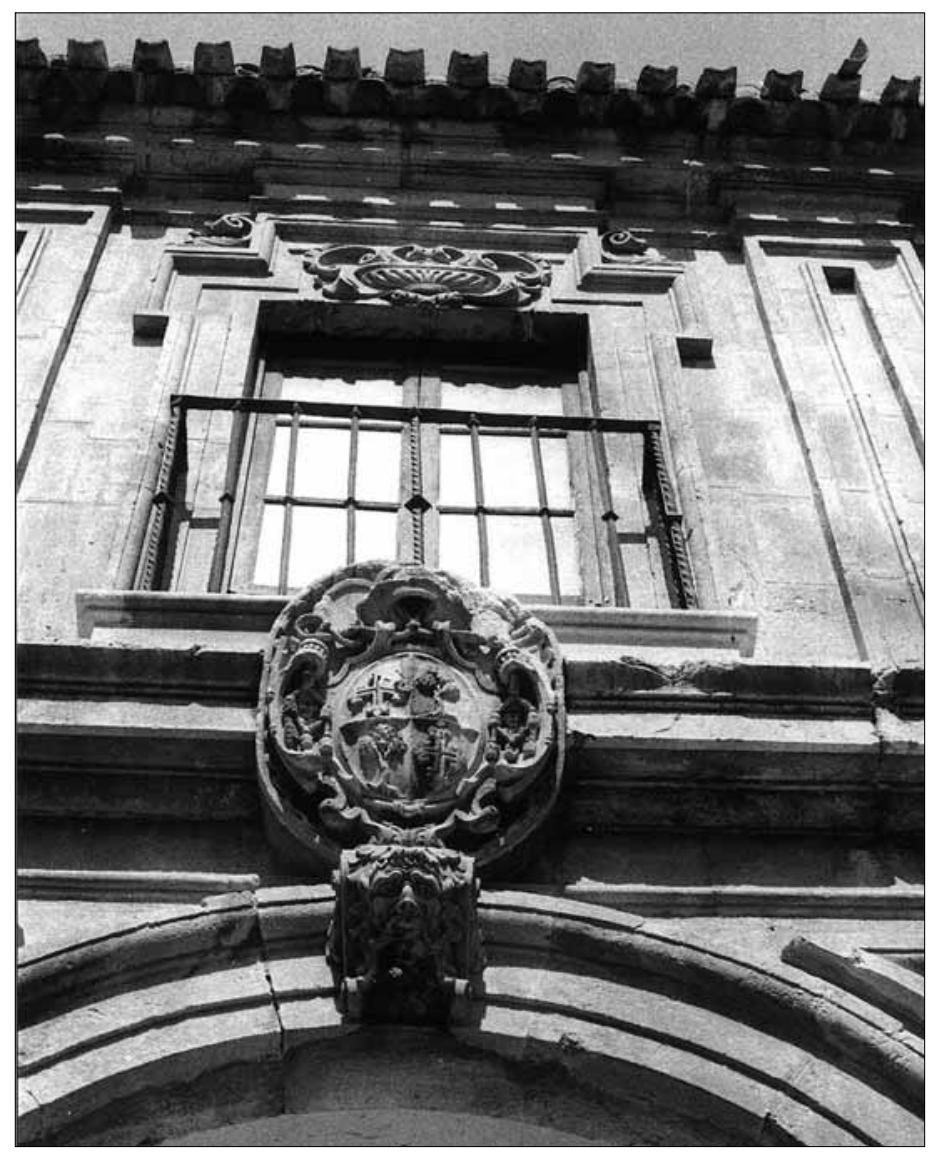

de Fray Francisco de Vitoria. 1979 


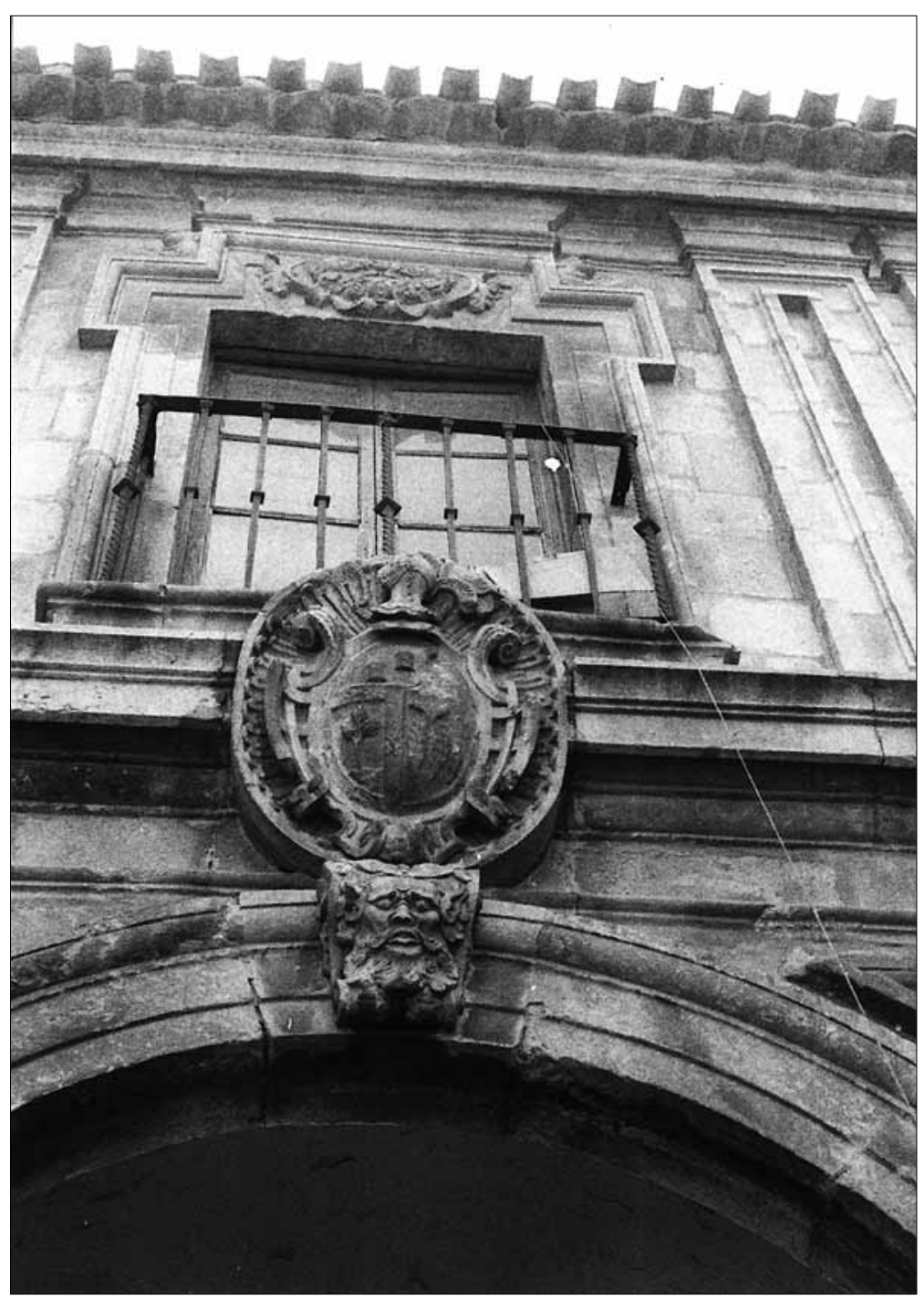

Lám. 50. Claustro. Escudo de armas de Don Juan Cerezo, Caballero Veinticuatro. 1979

Lám. 51. Claustro del patio principal, con el volumen de la iglesia. Lado Sur. 1979

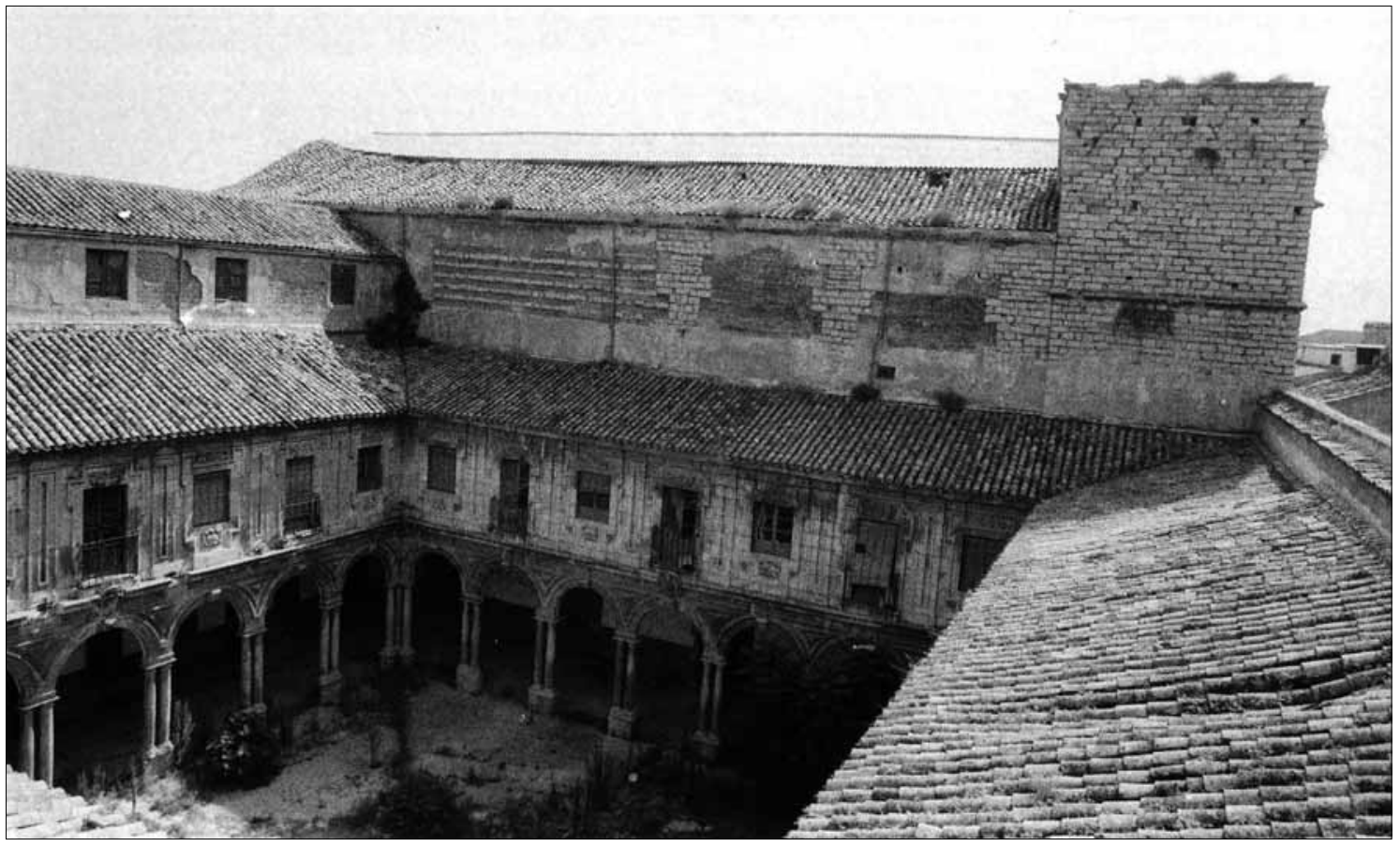




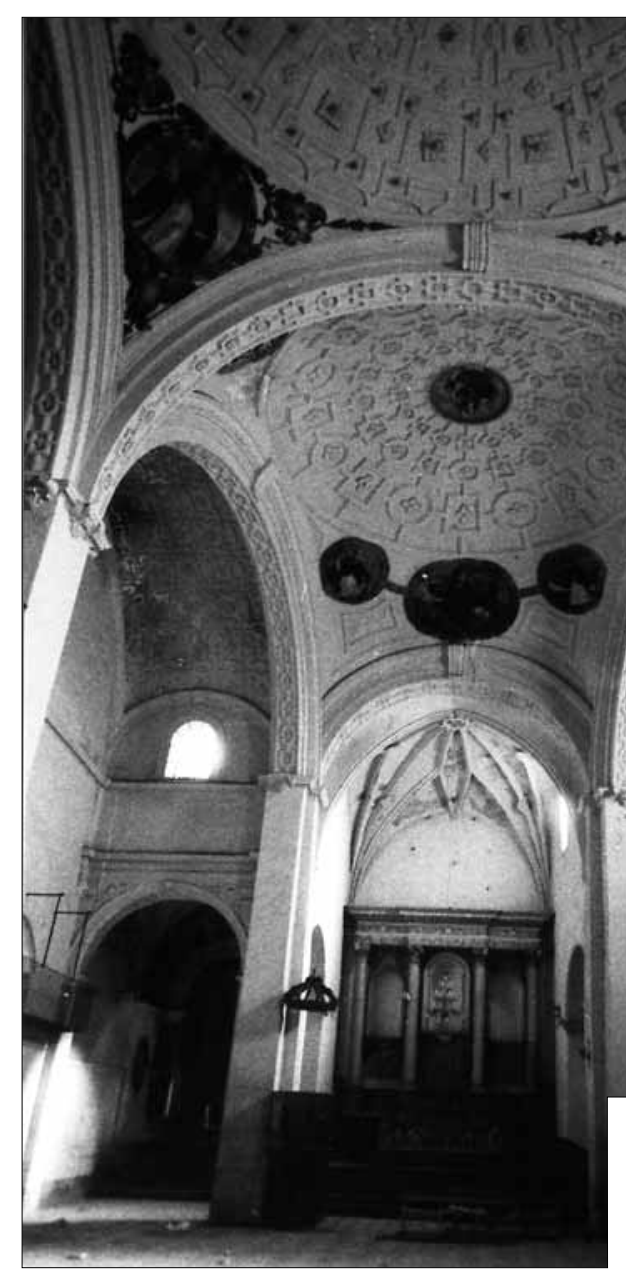

Lám. 52. Iglesia de Sto. Domingo iglesia y presbiterio. 1979

Lám. 53. Iglesia de Sto. Domingo. Coros Alto y Bajo, tabicados. Capillas laterales. 1979

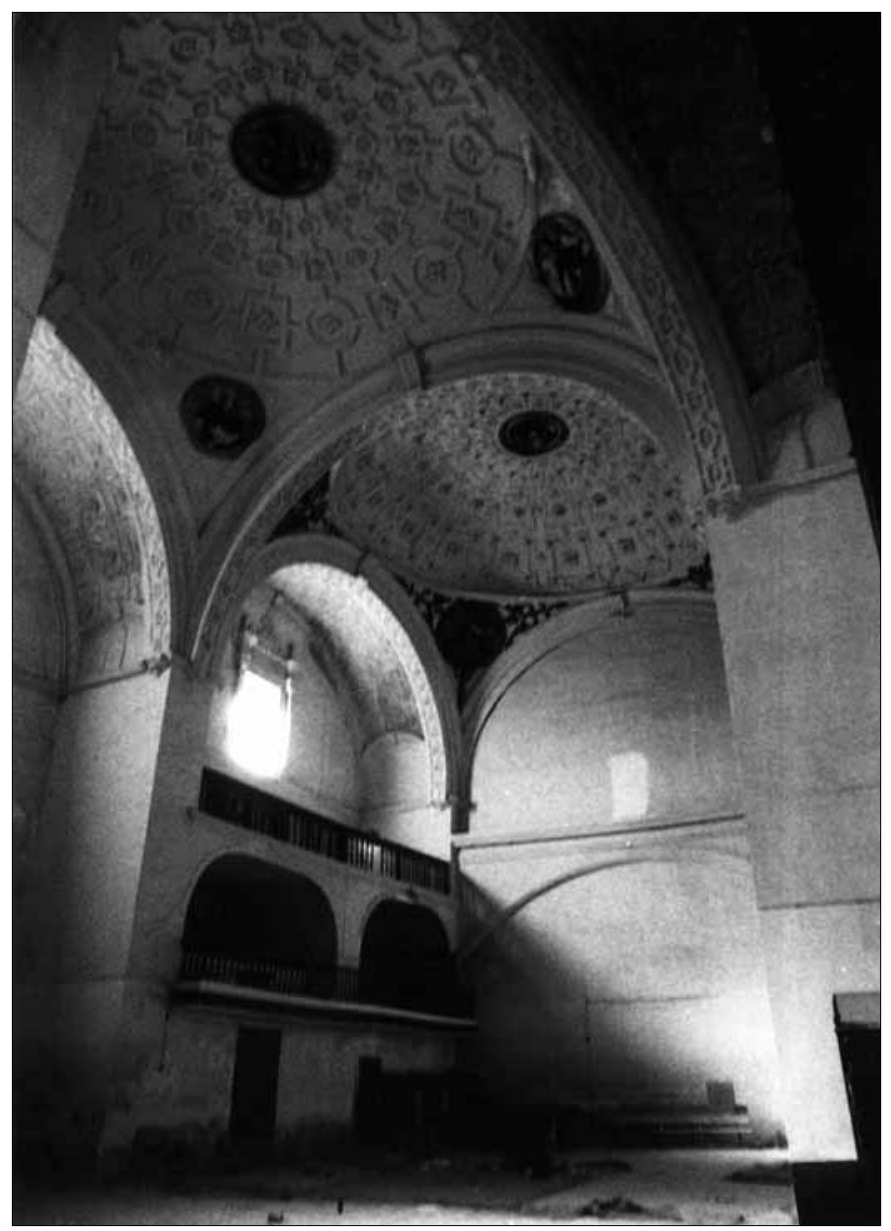




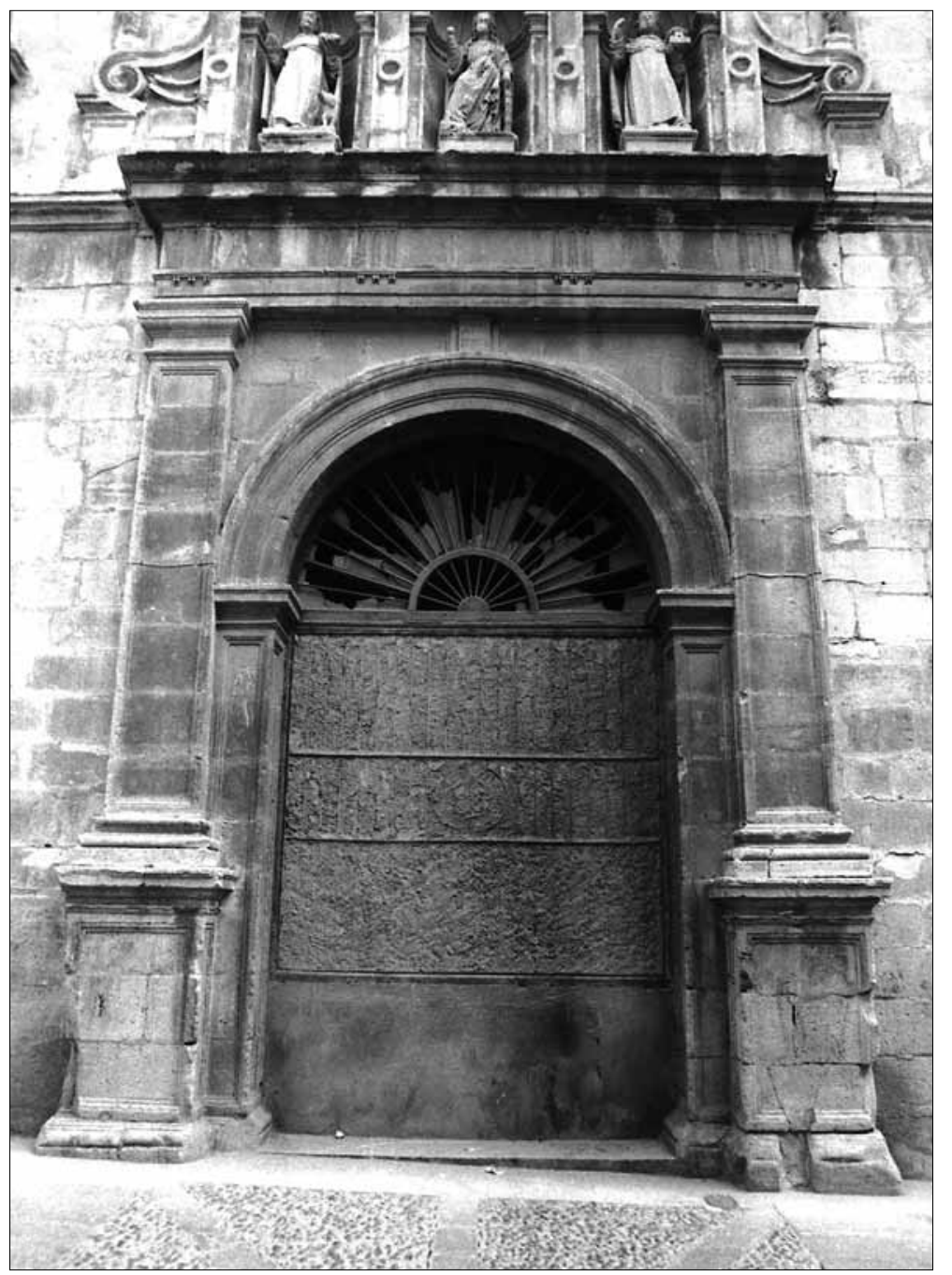

Lám. 54. Pta. principal de acceso a la iglesia de Sto. Domingo en la calle del mismo nombre

Lám. 55. Cuerpo alto de la portada de la puerta principal. 1979

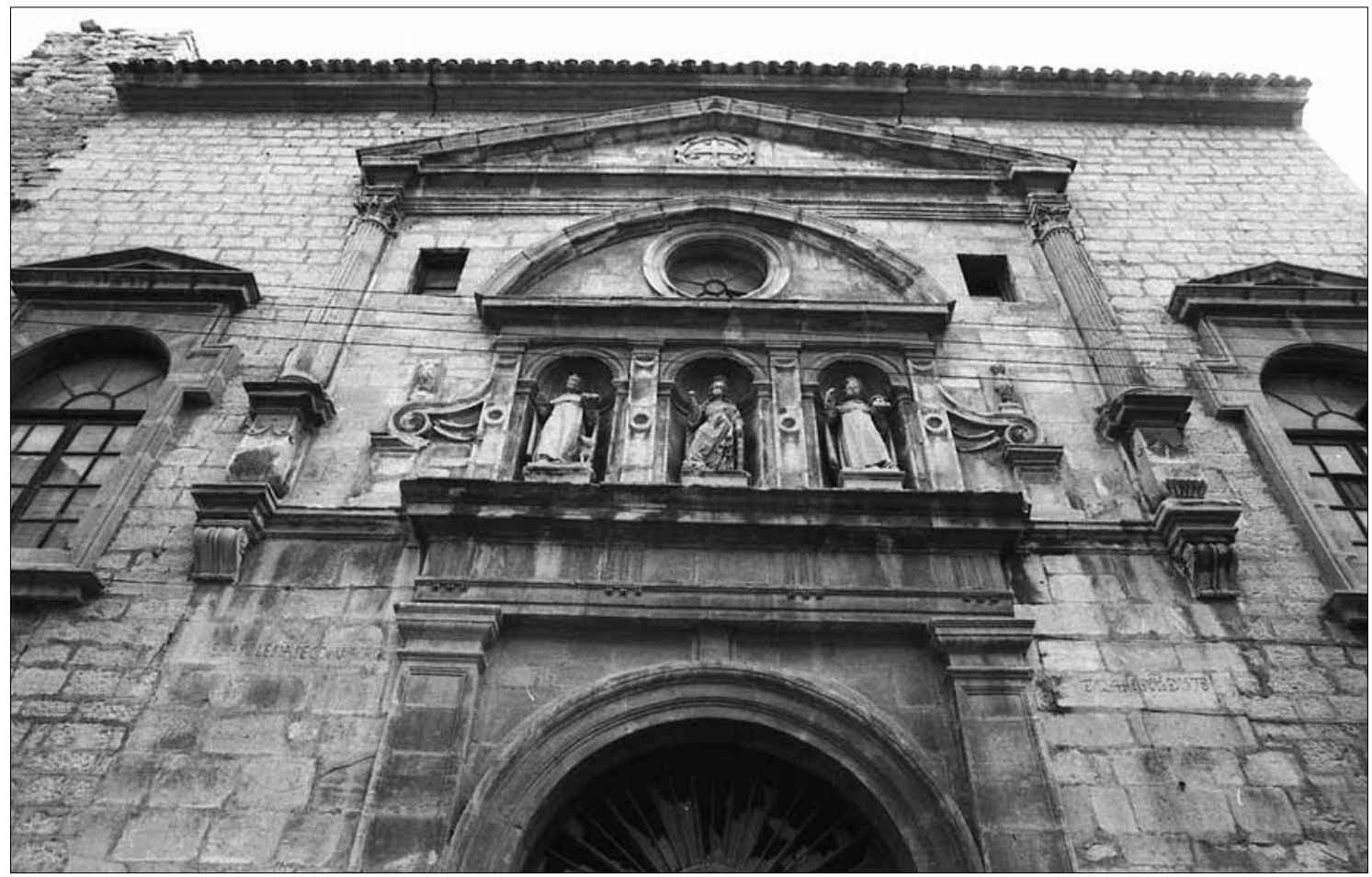


Lám. 56. Huecos de ventana a ambos lados de la portada, de la reforma de Luis Berges Martínez en 1924, desmontando toda la portada y adelantándola hasta enrasar con el resto de la fachada. 1979

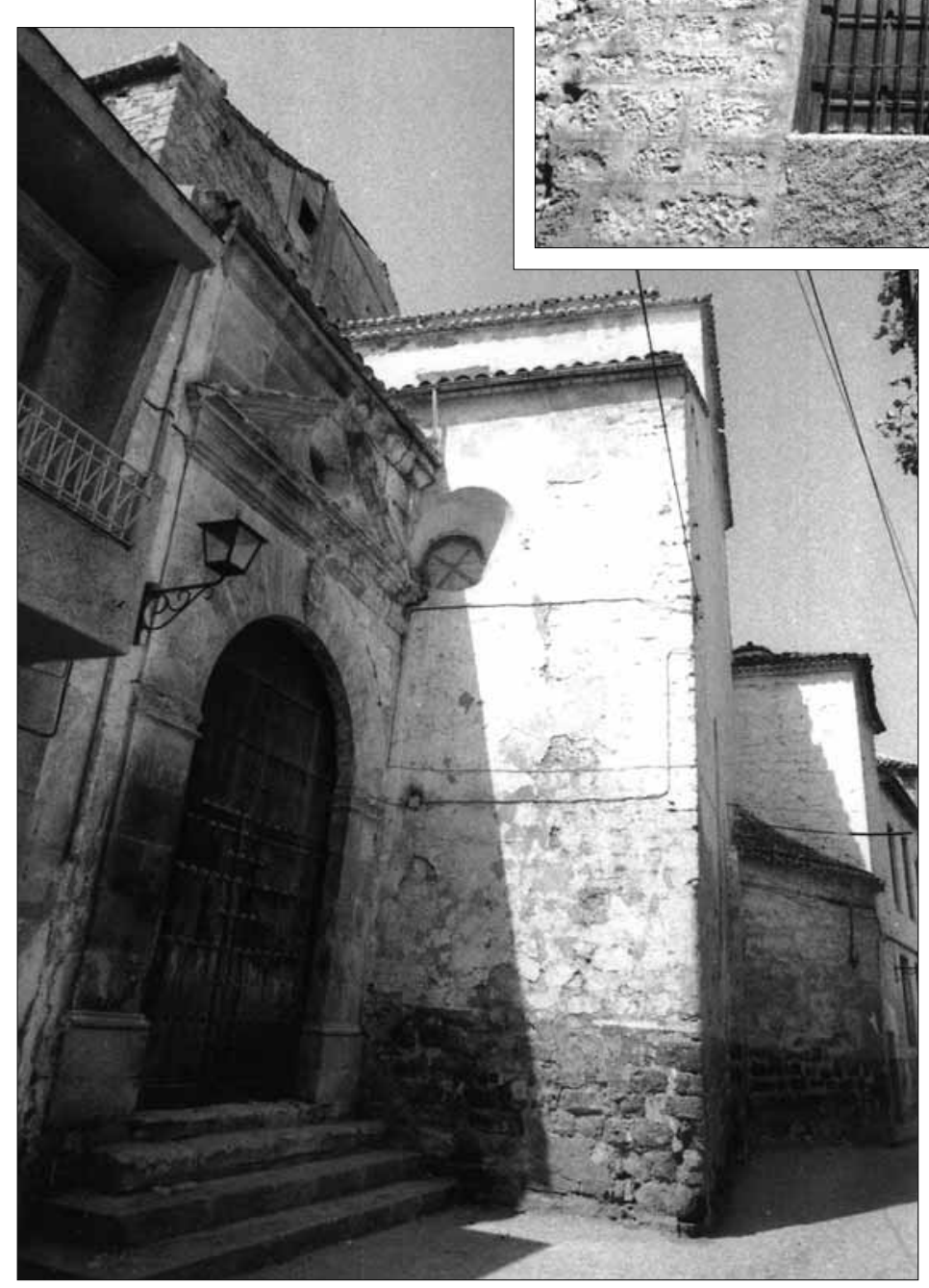

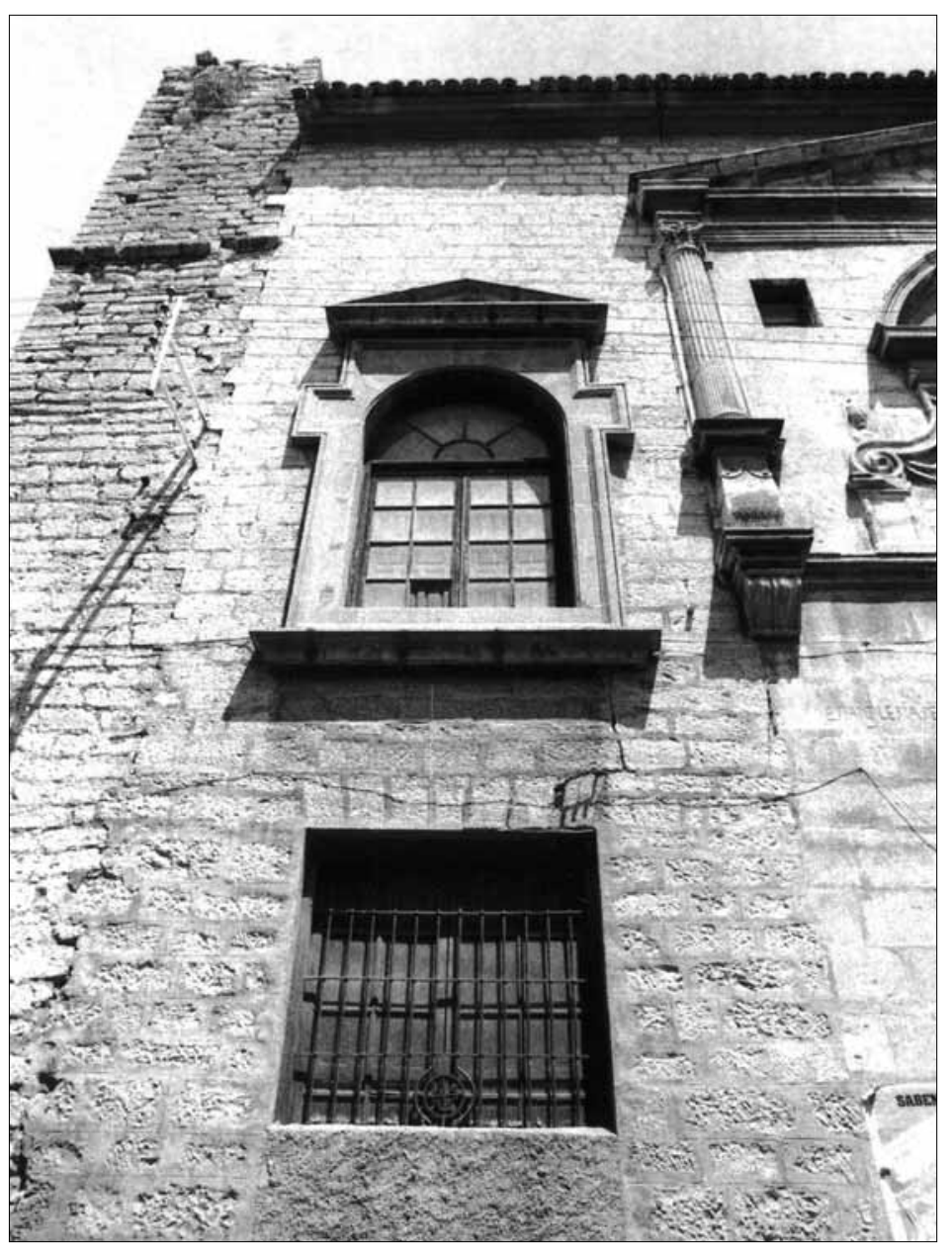

Lám. 57. Puerta de acceso por la calle de Los Uribe o Sto. Domingo Bajo a la iglesia de Sto. Domingo. 1979 


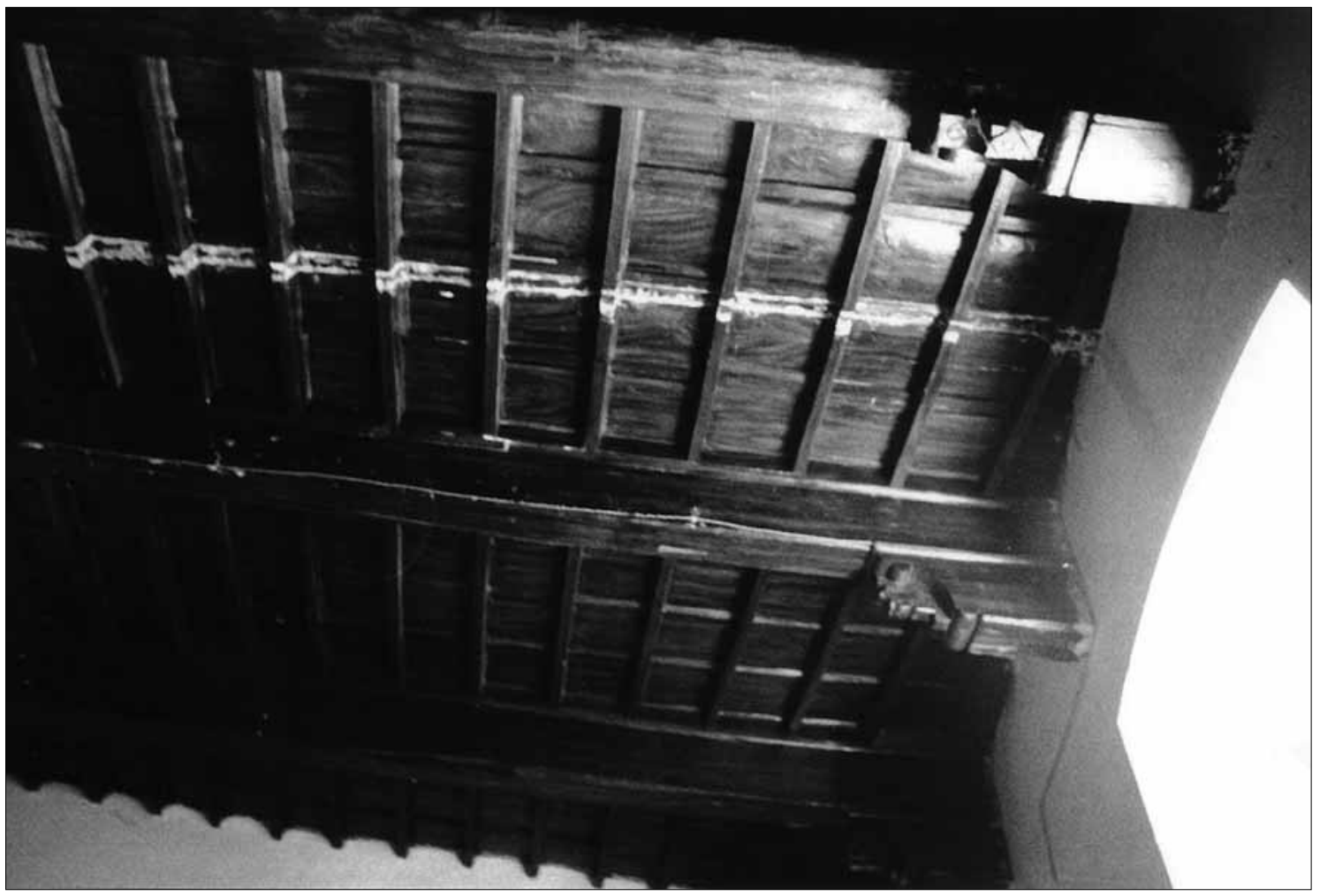

Lám. 58. Iglesia de Sto. Domingo. Alfarje de la sacristía. 1979

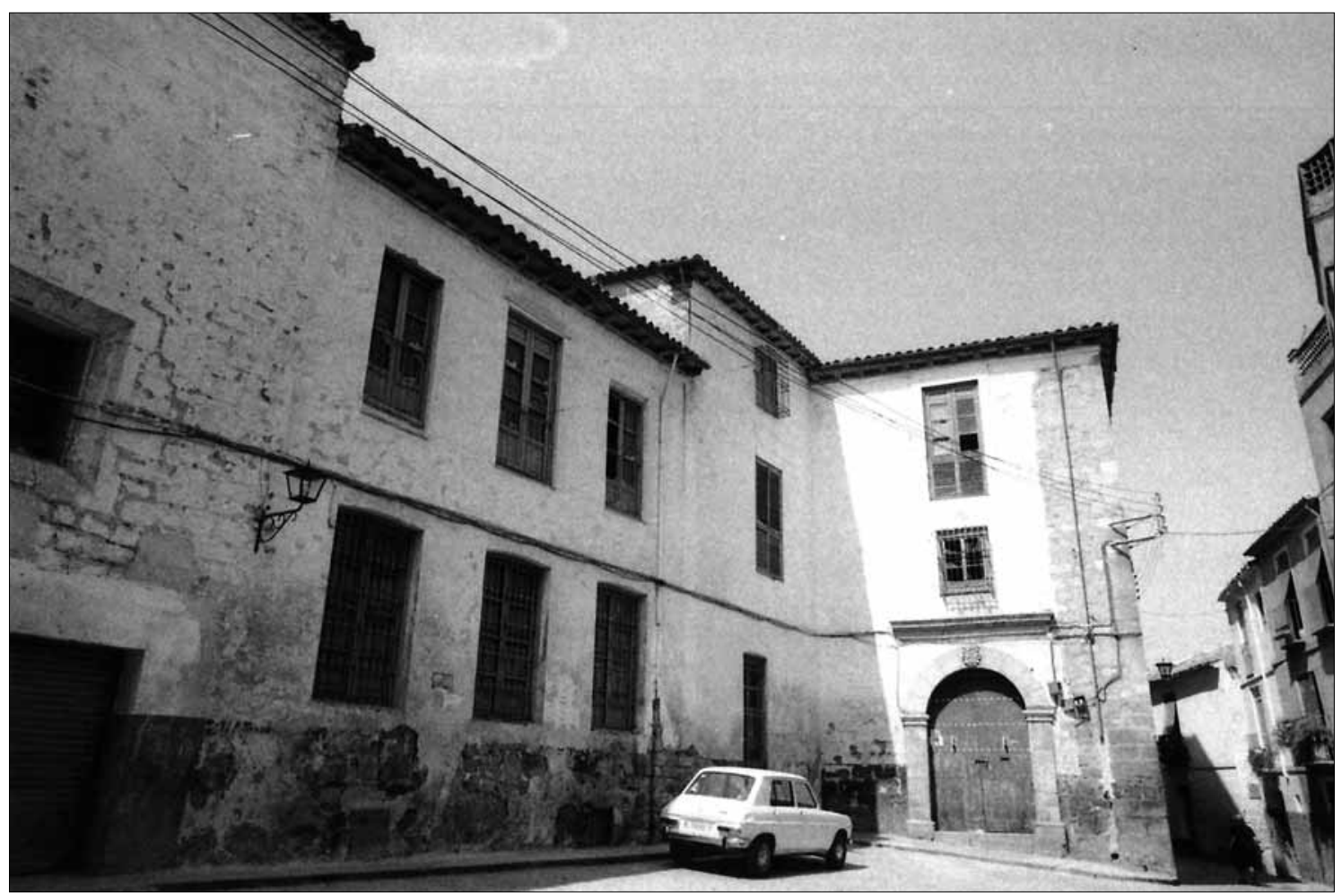

Lám. 59. Fachada a la plazuela de Sto. Domingo, 1979 


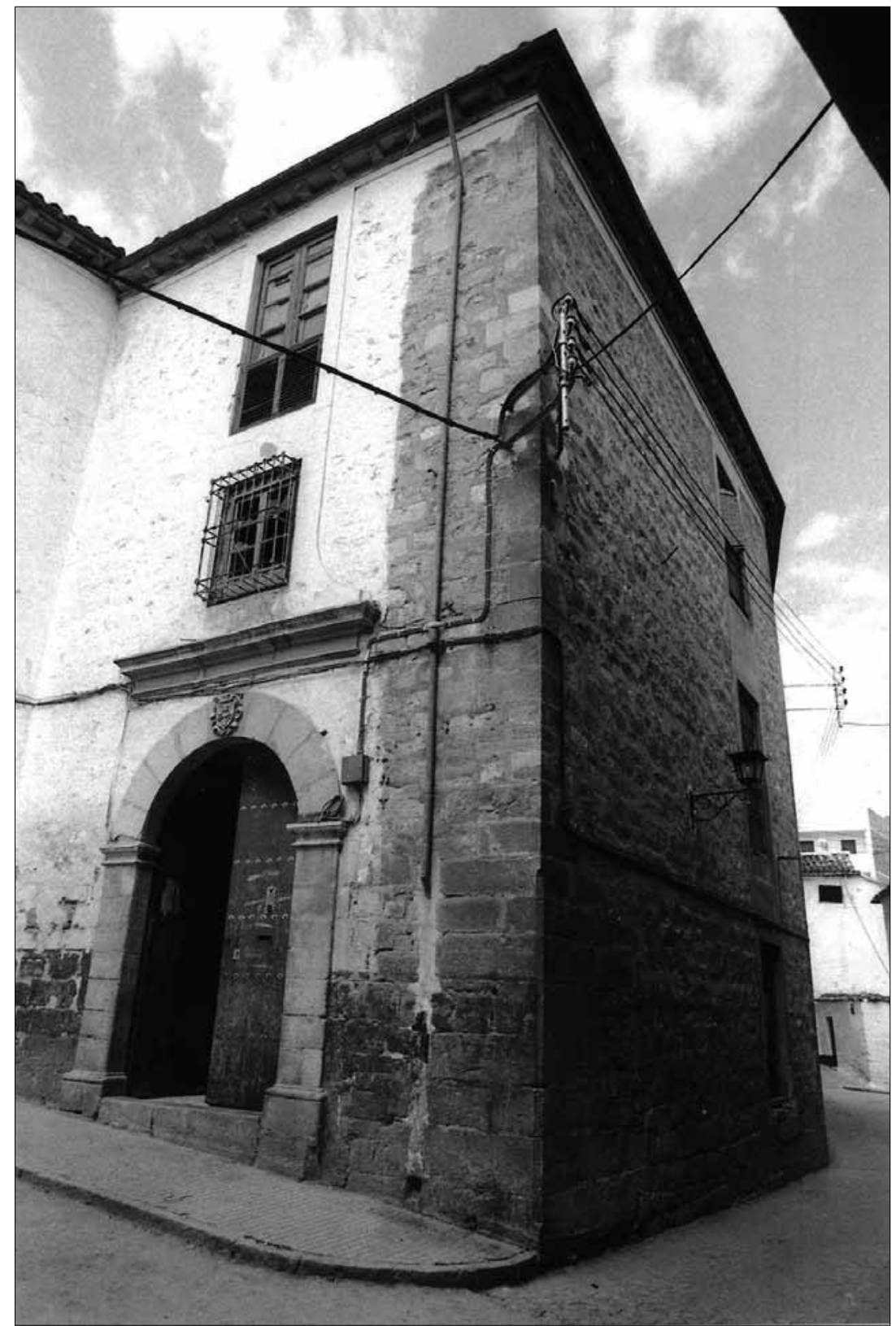

Lám. 60. Detalle de la puerta principal de entrada, 1979 
Lám. 61. Proyecto de Vicente Serrano Salaverri (6-XI-1865) Reforma y ampliación en el llamado patio primero. Sección (Expte. 3635/1 A.S.J.D.)
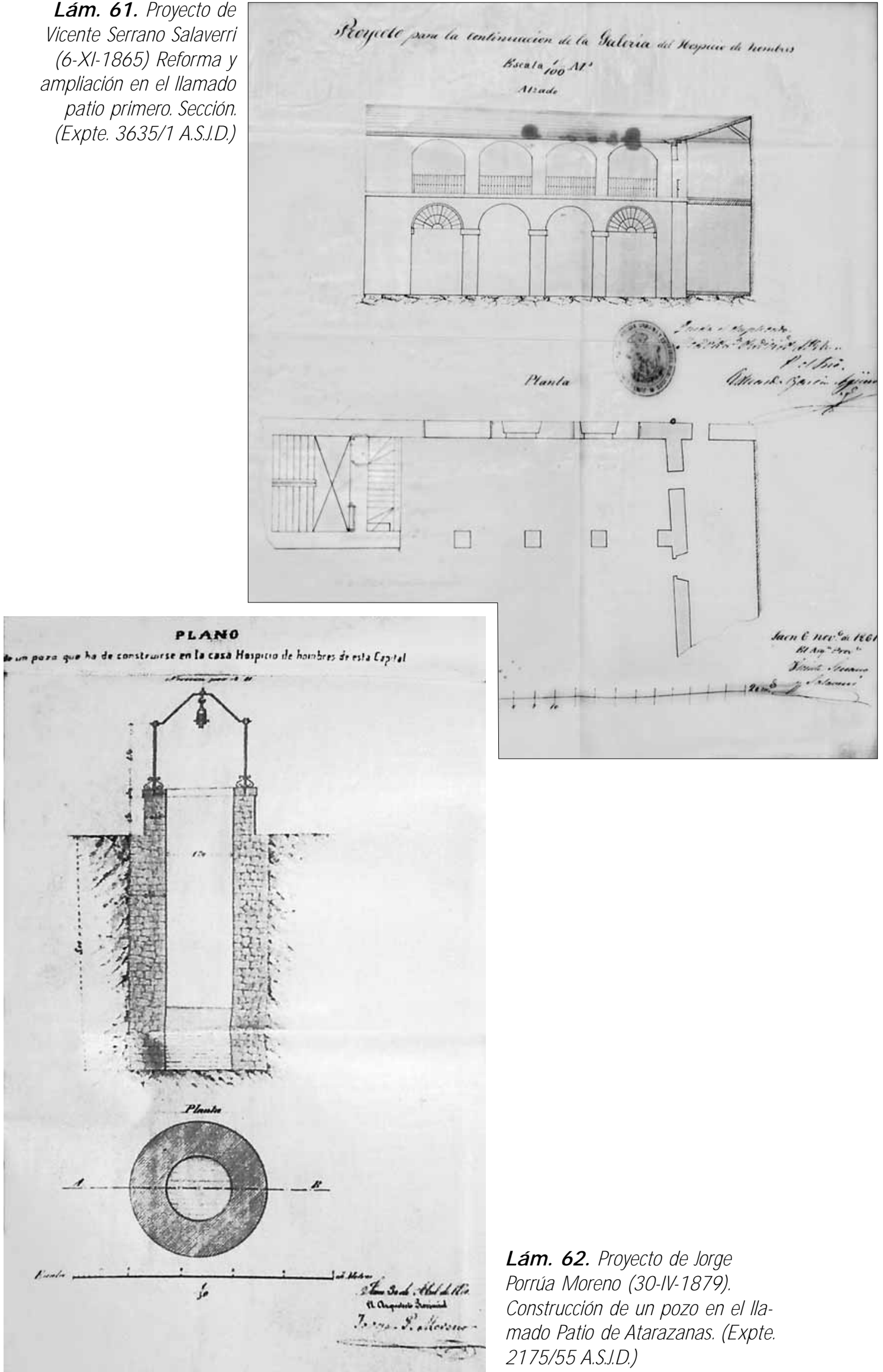

Lám. 62. Proyecto de Jorge Porrúa M oreno (30-IV-1879). Construcción de un pozo en el llamado Patio de Atarazanas. (Expte. 2175/55 A.S..D.) 


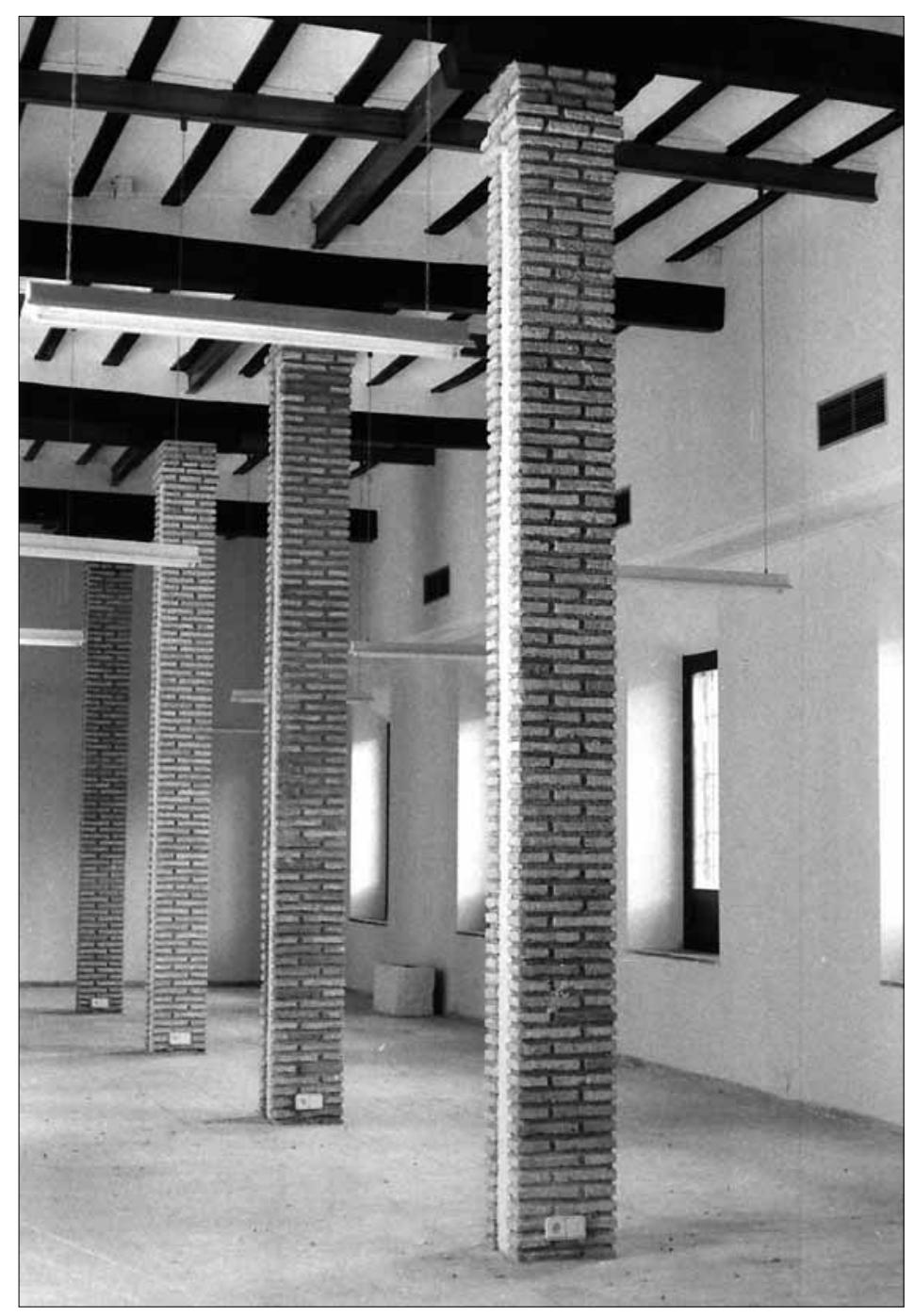

Lám. 63. Antiguos talleres de tejidos y carpintería donde en 1875 se colocaron columnas de fundición. En 1981 se revistieron de ladrillo para protección contra el fuego en la obras de la sala de investigadores.

Lám. 64. Testimonios de la entreplanta destinada a sala de las cunas, hoy control y biblioteca básica de consulta. 1981

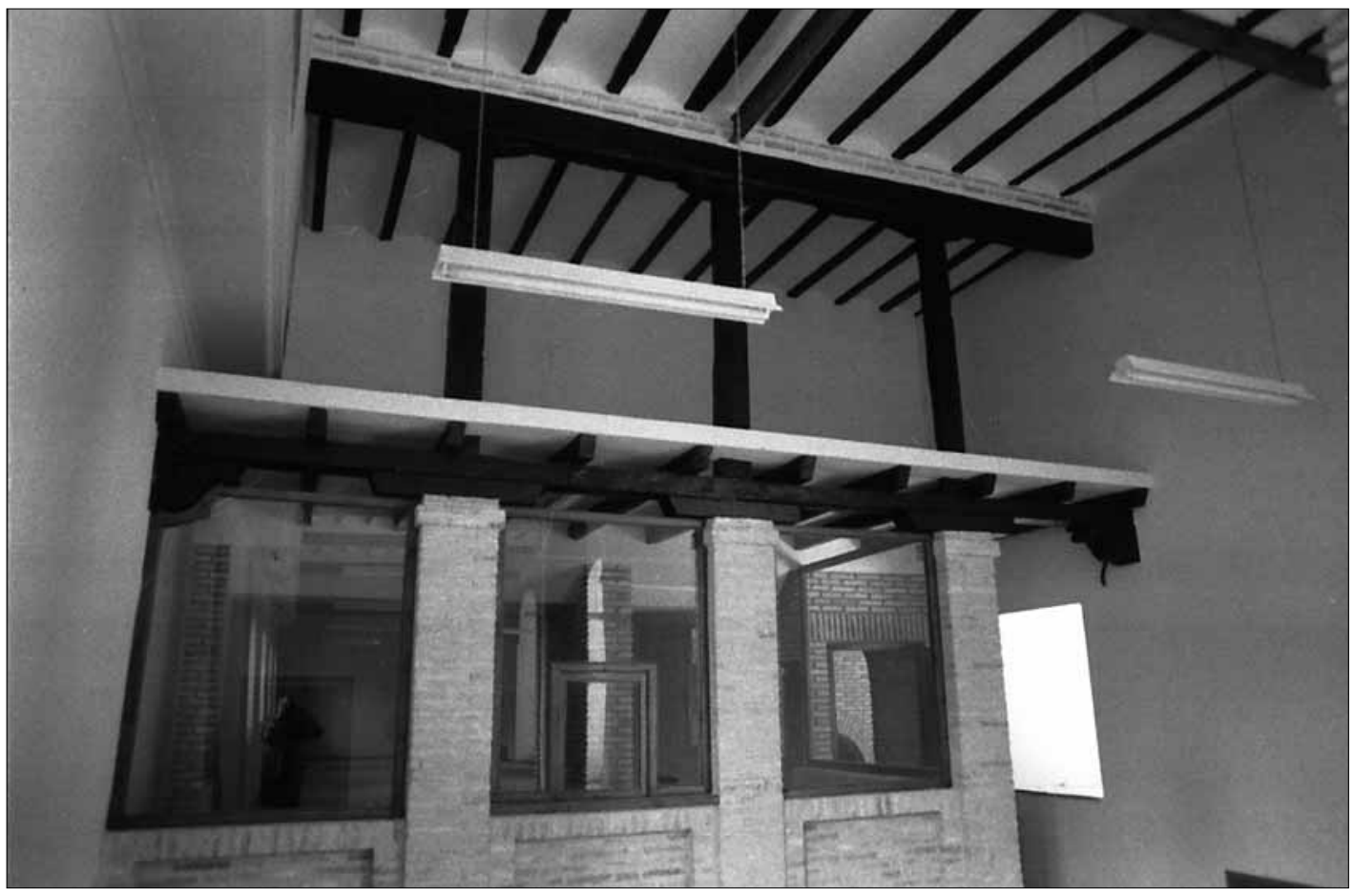




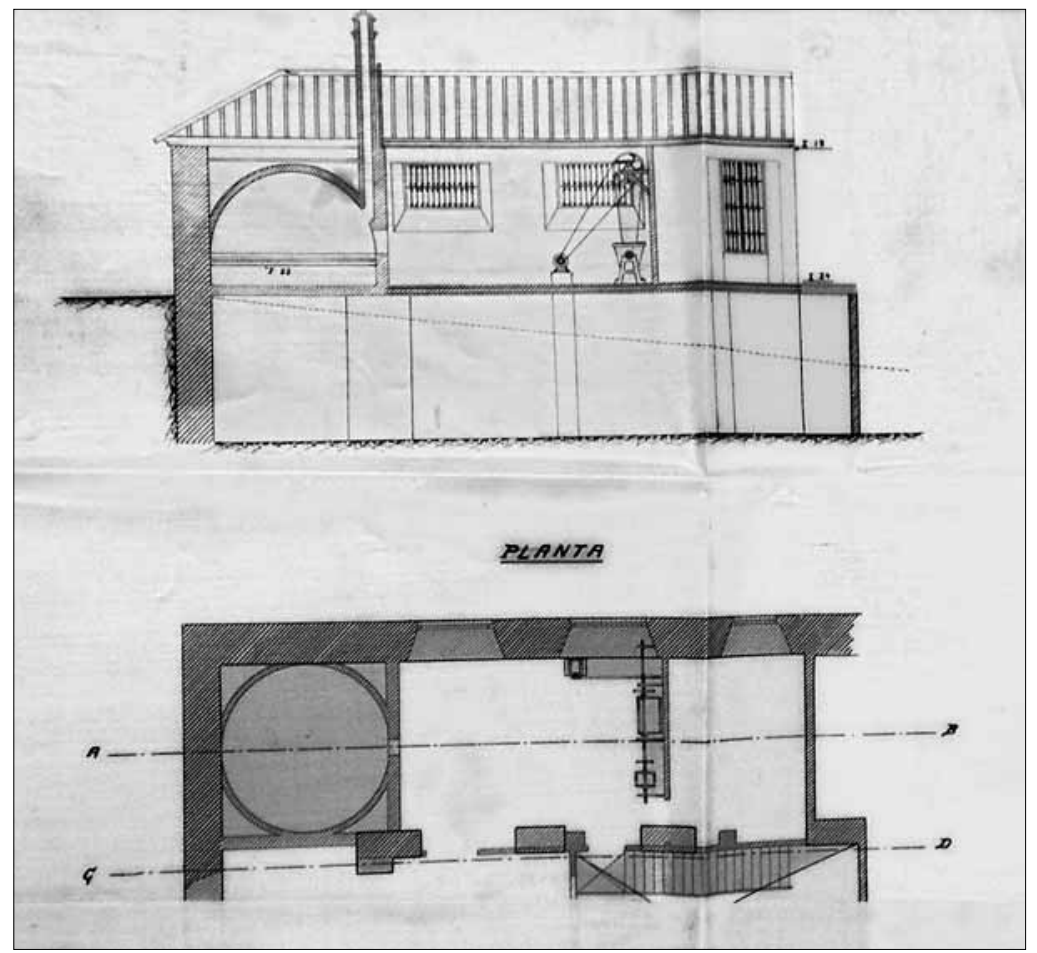

Lám. 65. Panificadora en el Patio de Atarazanas

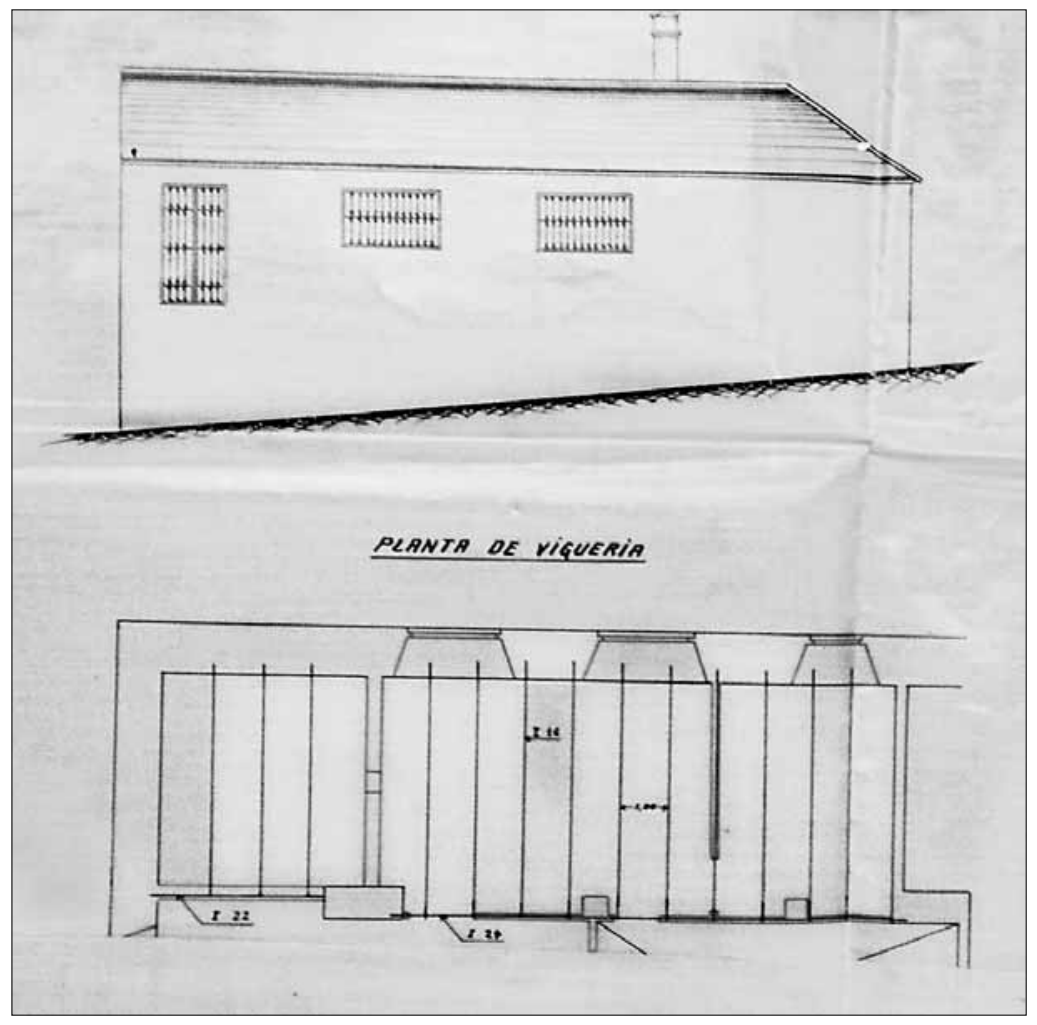

Lám. 66. Proyecto de Luis Berges Martínez (11-XI-1925, Expte. 3790/7,A.S.J.D.) 


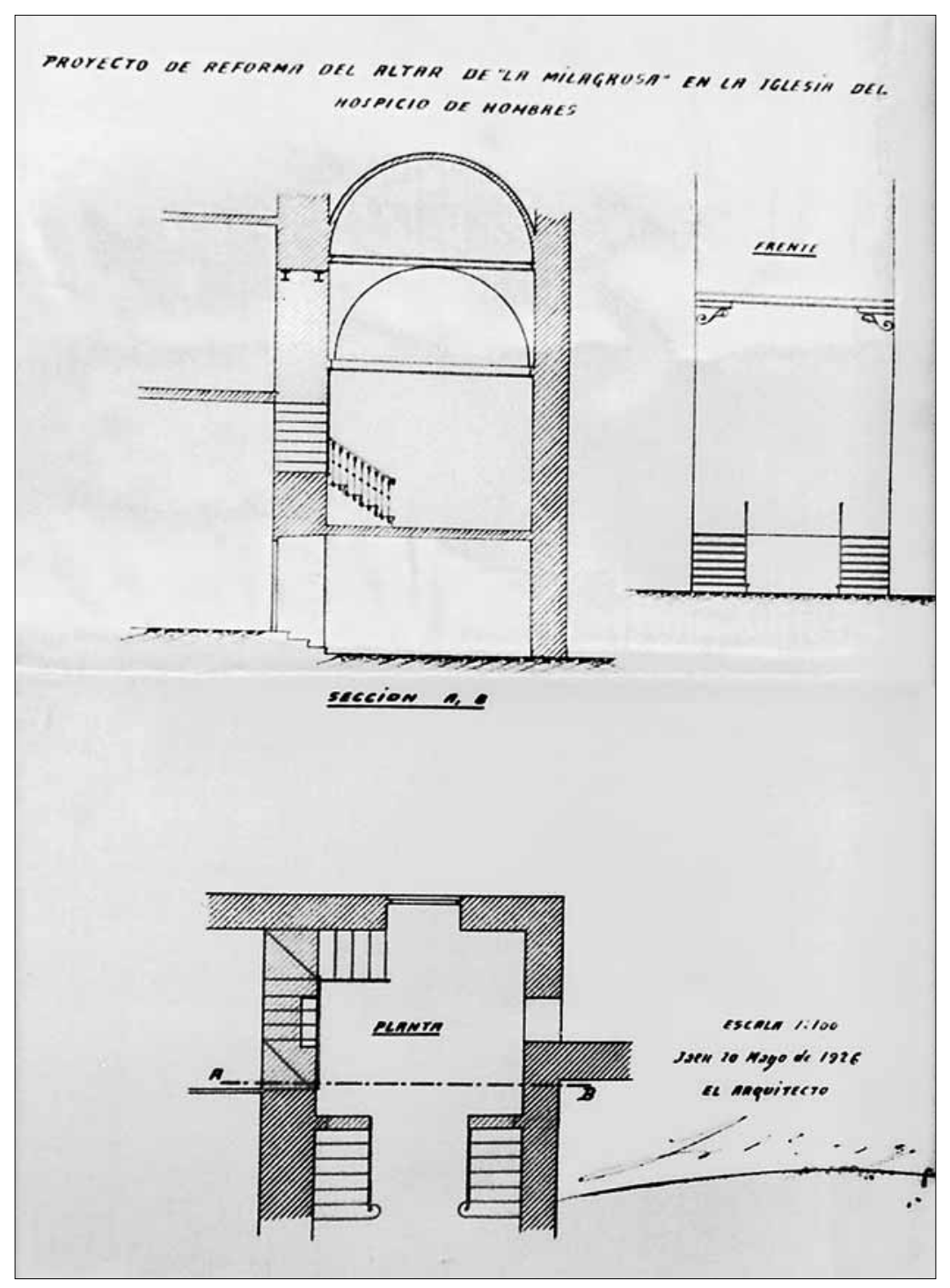

Lám. 67. Proyecto de Luis Berges Martínez (septiembre 1926) del altar de "La M ilagrosa" junto al presbiterio de la iglesia de Sto. Domingo. (Expte. 3790/7,A.S.J.D.)

Lám. 68. Deformación típica del Claustro, que dio lugar a sucesivas restauraciones de las cuatro pandas del mismo, por Luis Berges Martínez durante los años 1931 y siguientes. 1979

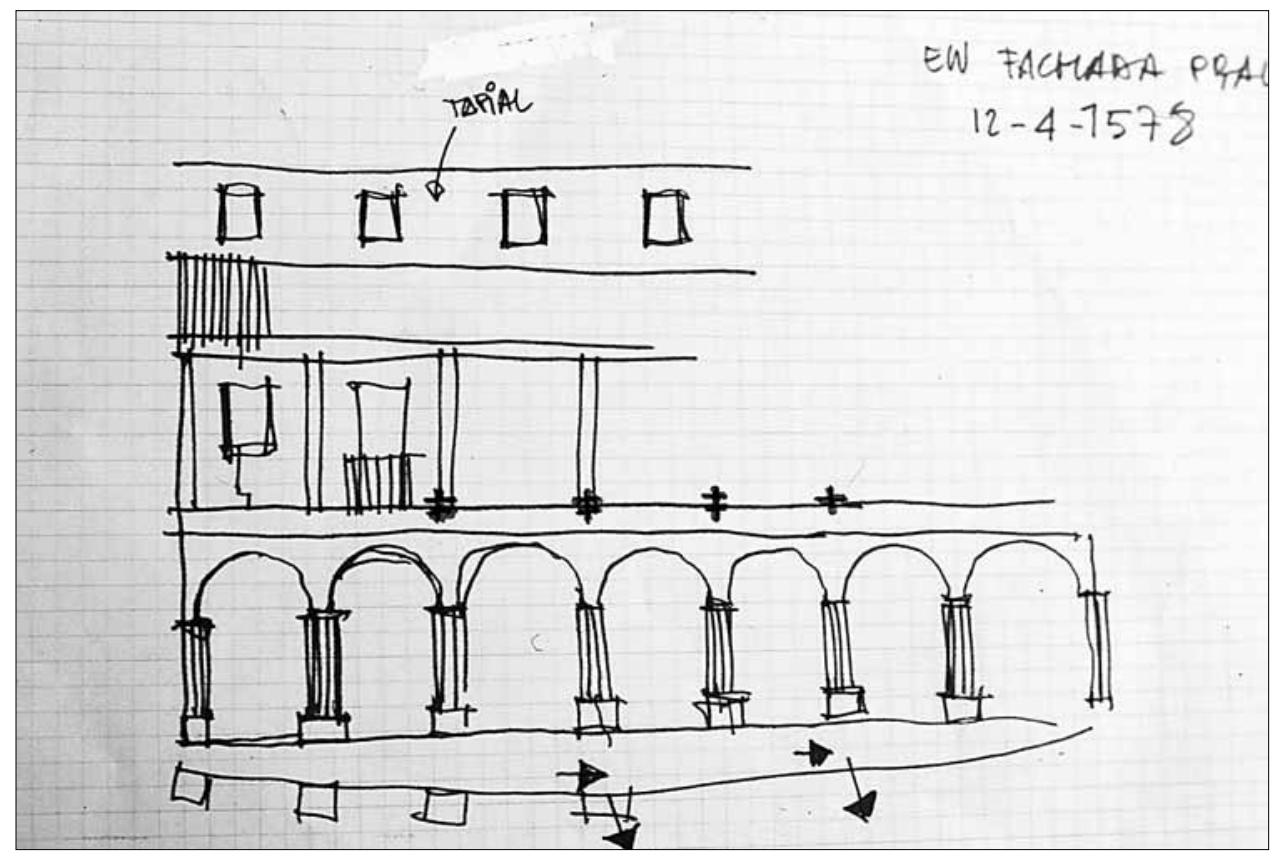




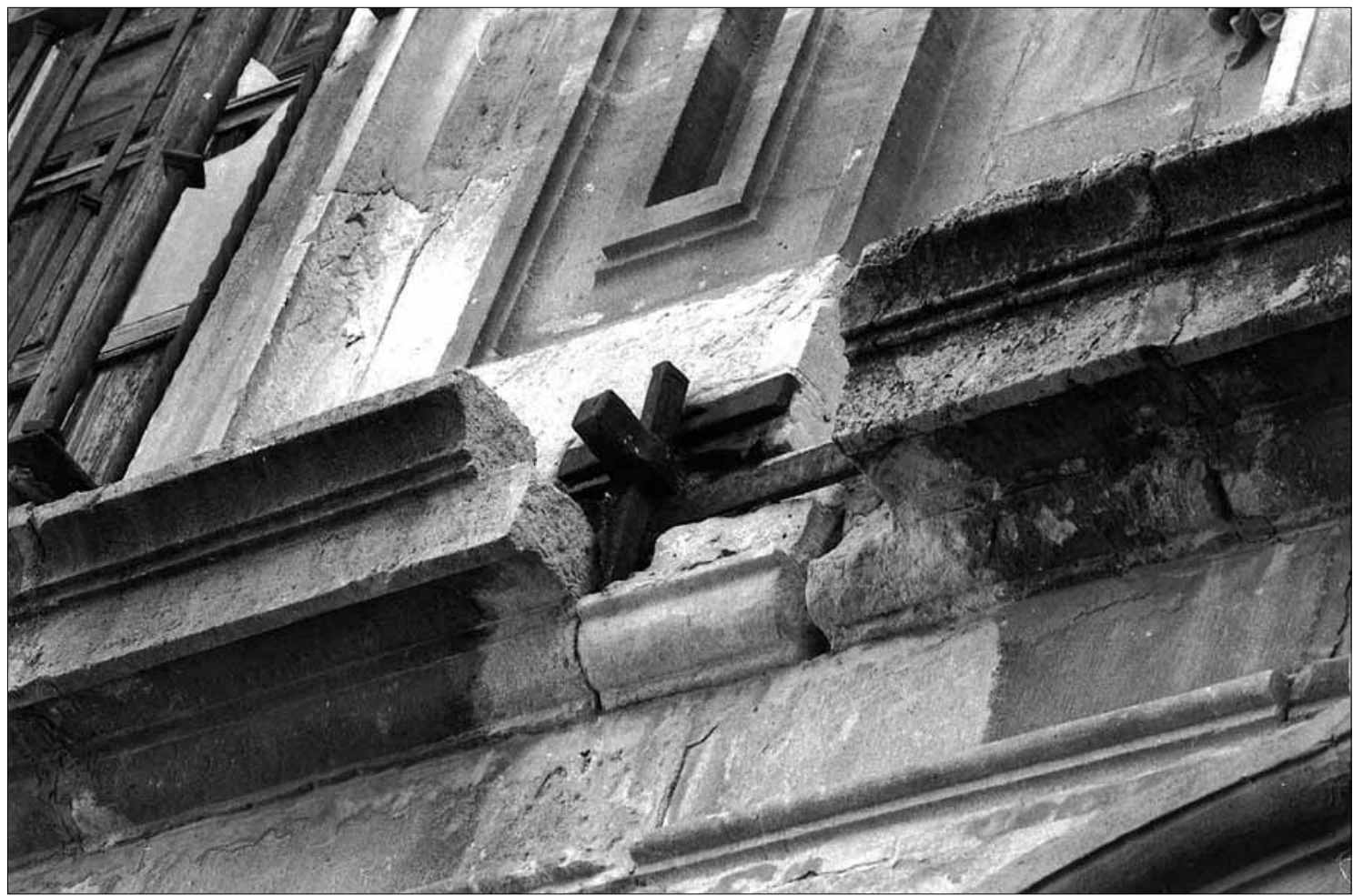

Lám. 69. Claustro. Anclajes de tirantes metálicos en el forjado sobre la galería baja. 1979

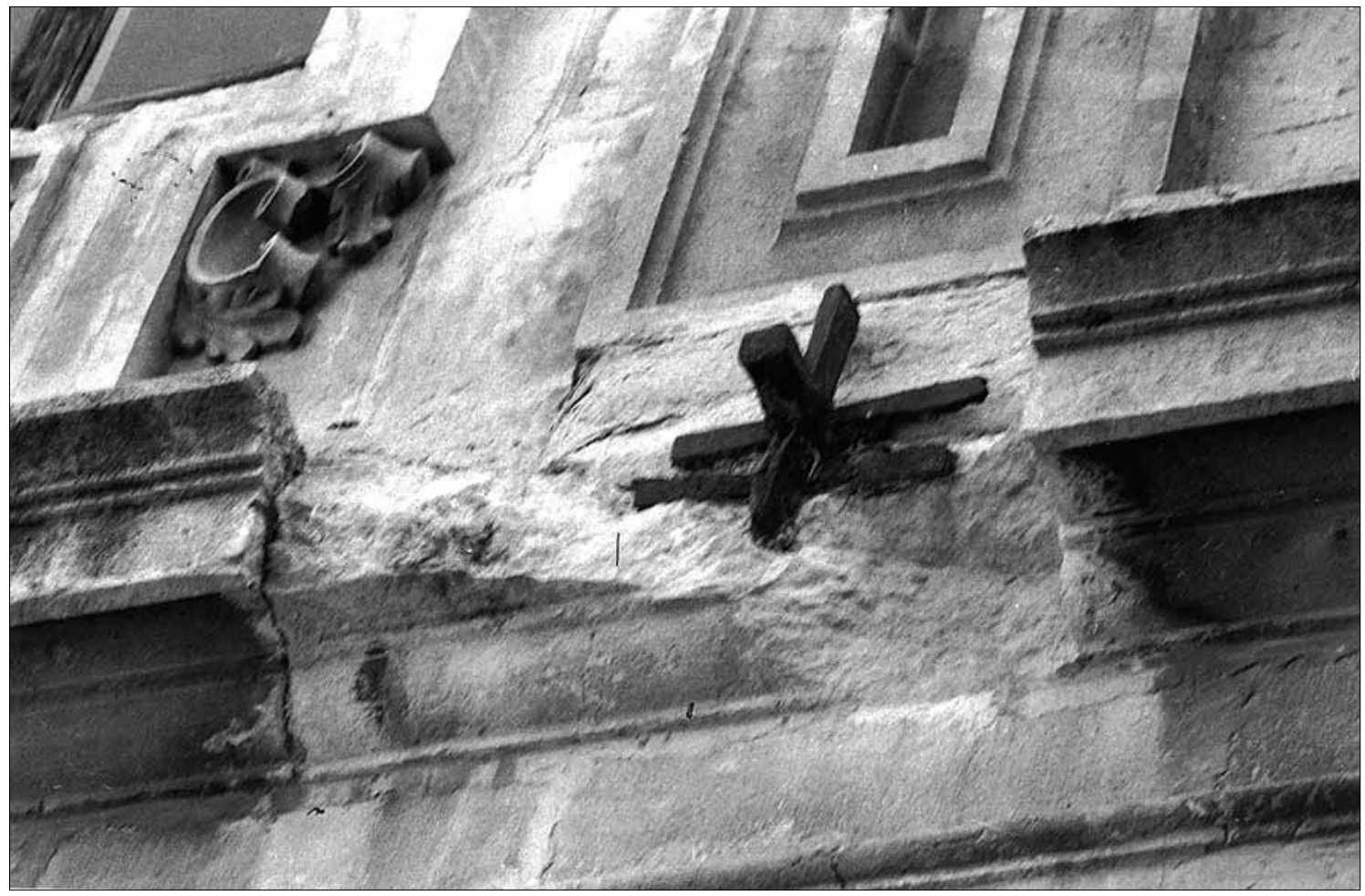

Lám. 70. Claustro. Al oxidarse los anclajes y aumentar el volumen dieron lugar al estallido de los sillares de la imposta. 1979 


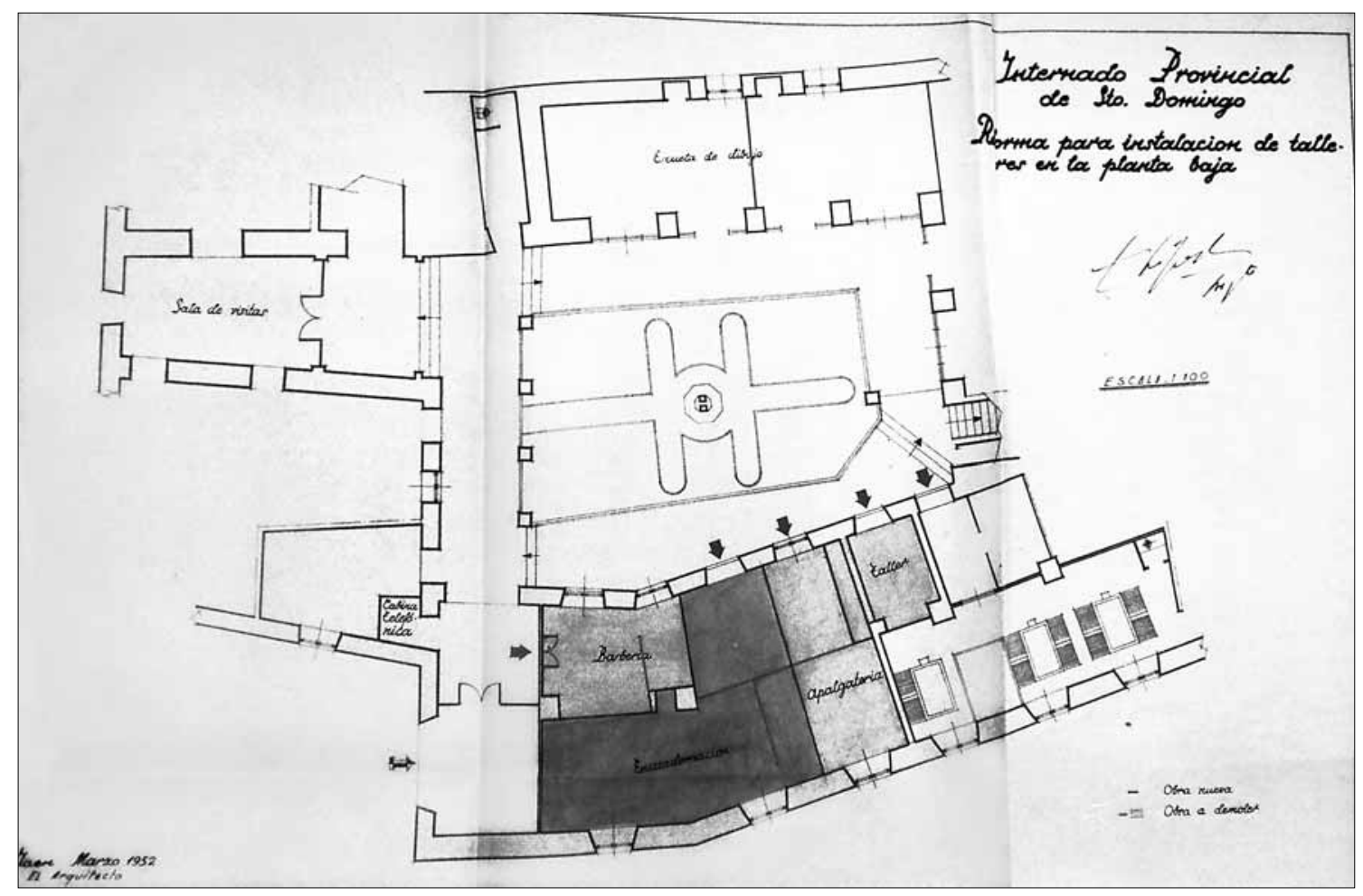

Lám. 71. Proyecto de Francisco de Paula López Rivera (marzo 1953). Reforma interior para talleres en el llamado patio primero. (Expte. 151/80,A.S.J.D.)

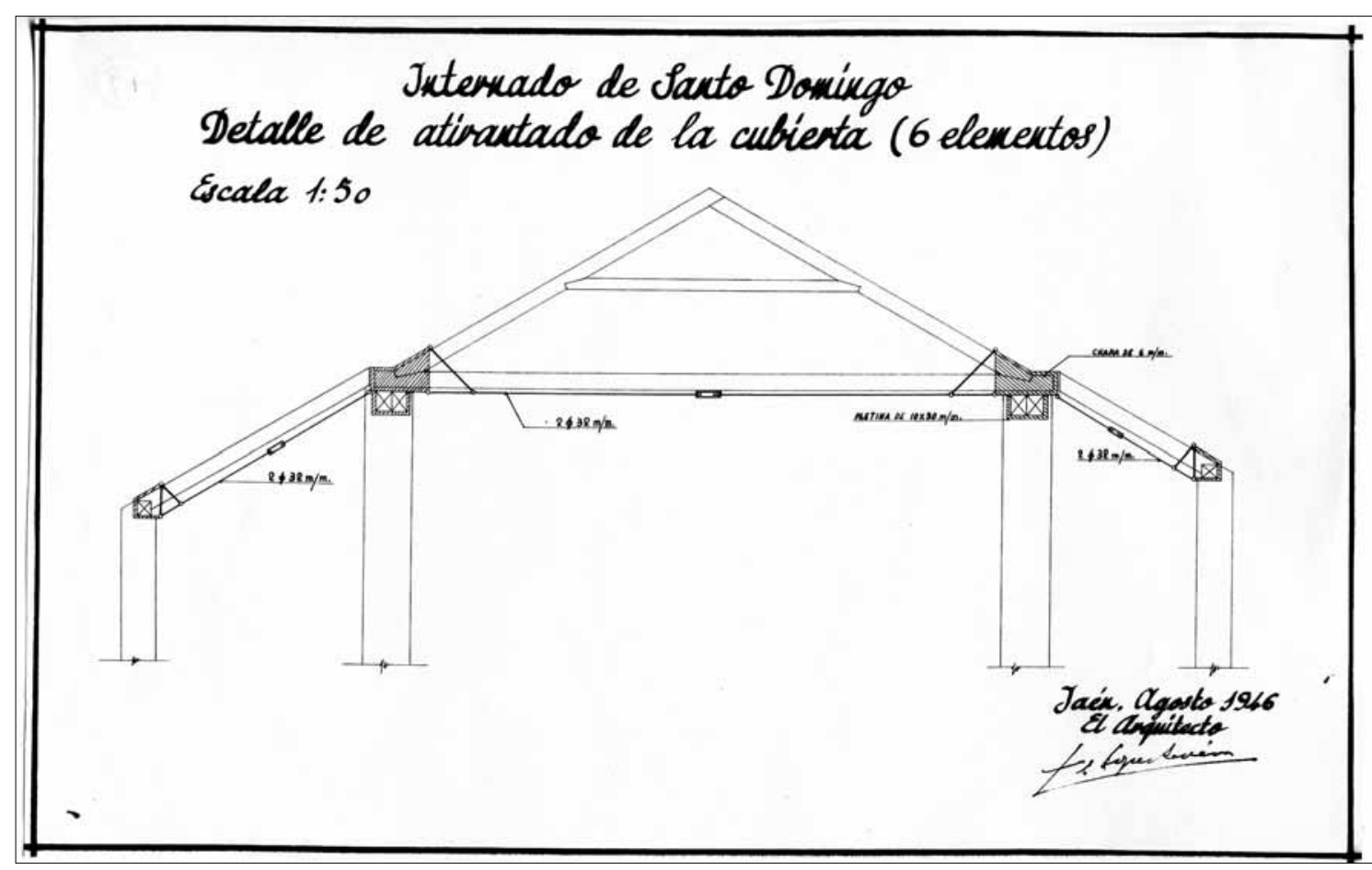

Lám. 72. Proyecto de Francisco de Paula López Rivera (agosto 1946). Detalle del atirantado de la cubierta. (Expte. 74/3 A.S.J.D.) 


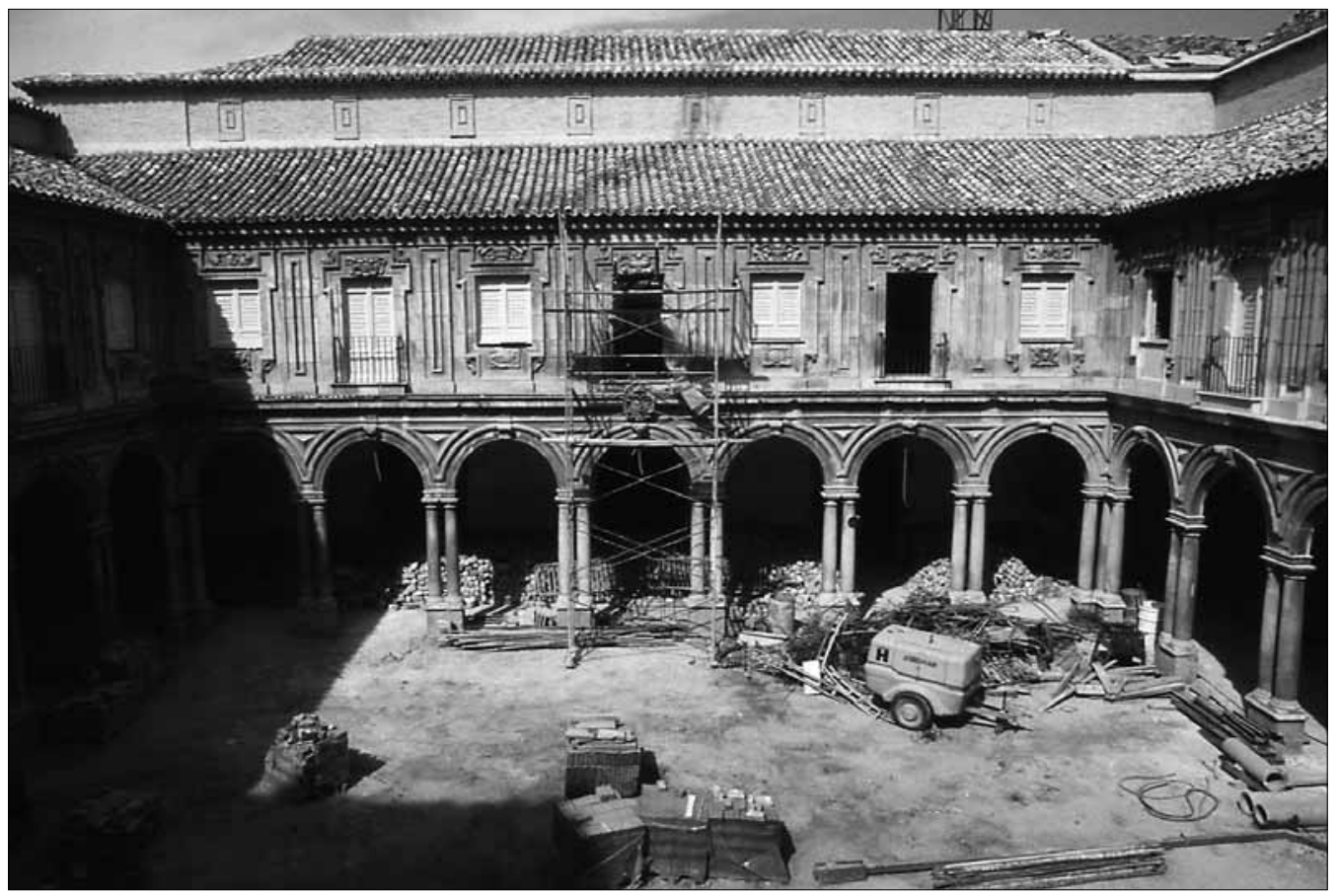

Lám. 73. Trabajos en el patio del Claustro. 1981

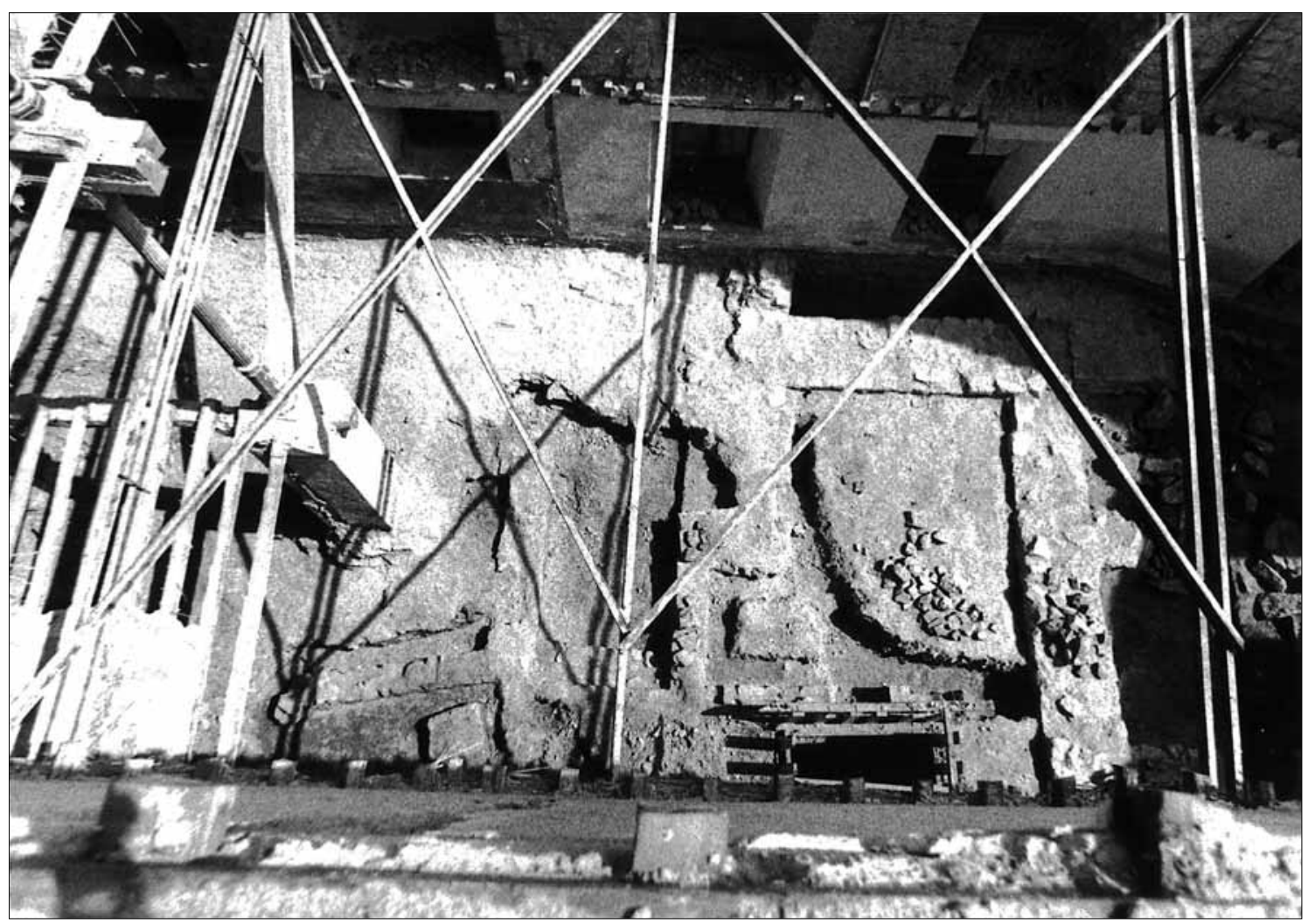

Lám. 74. Hallazgo de muros antiguos en los trabajos de cimentación en la crujía a la calle de Sto. Domingo. 1981 


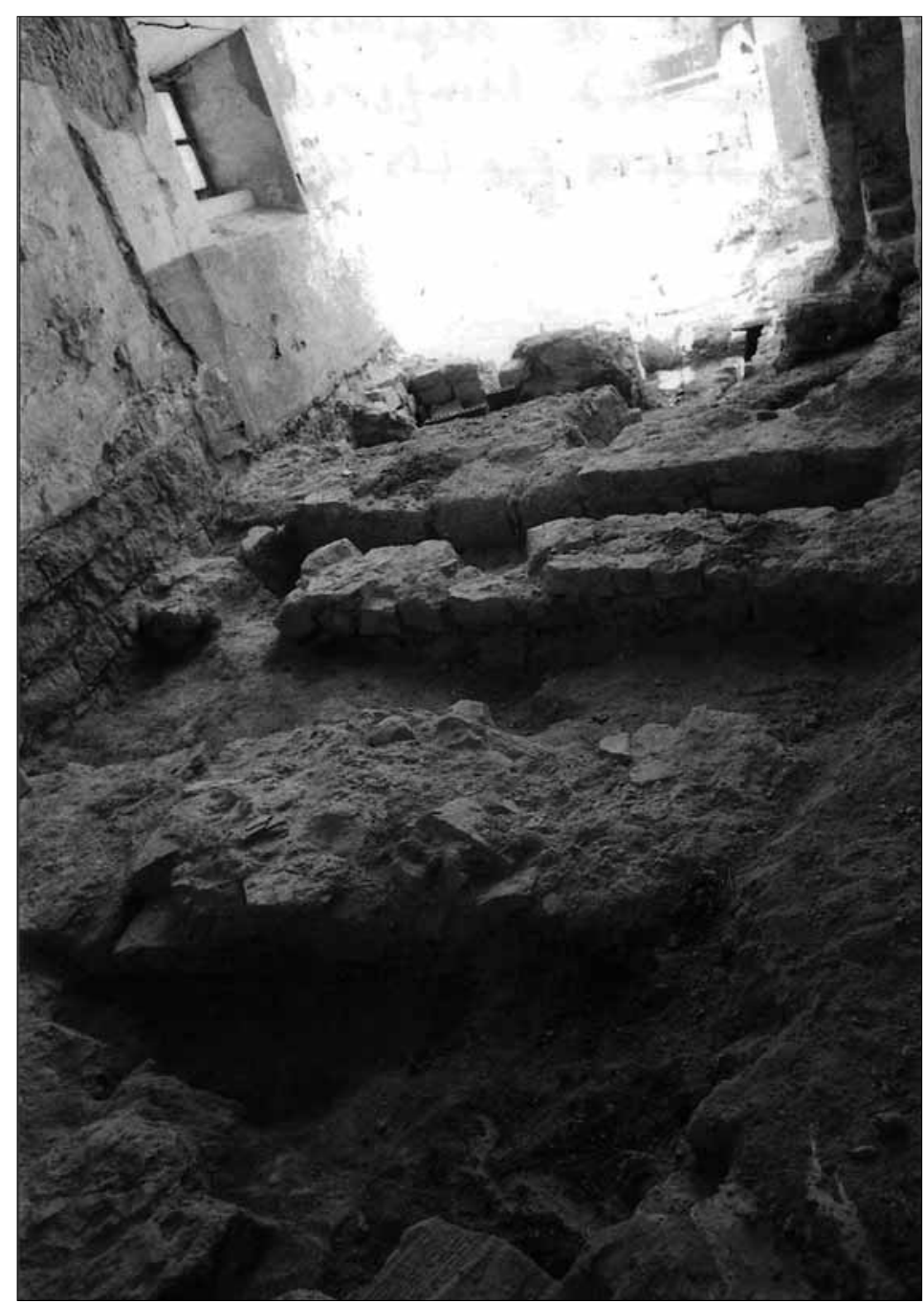

Lám. 75. Detalle de los muros

hallados en la excavación. 1981

Lám. 76. Detalle de los muros

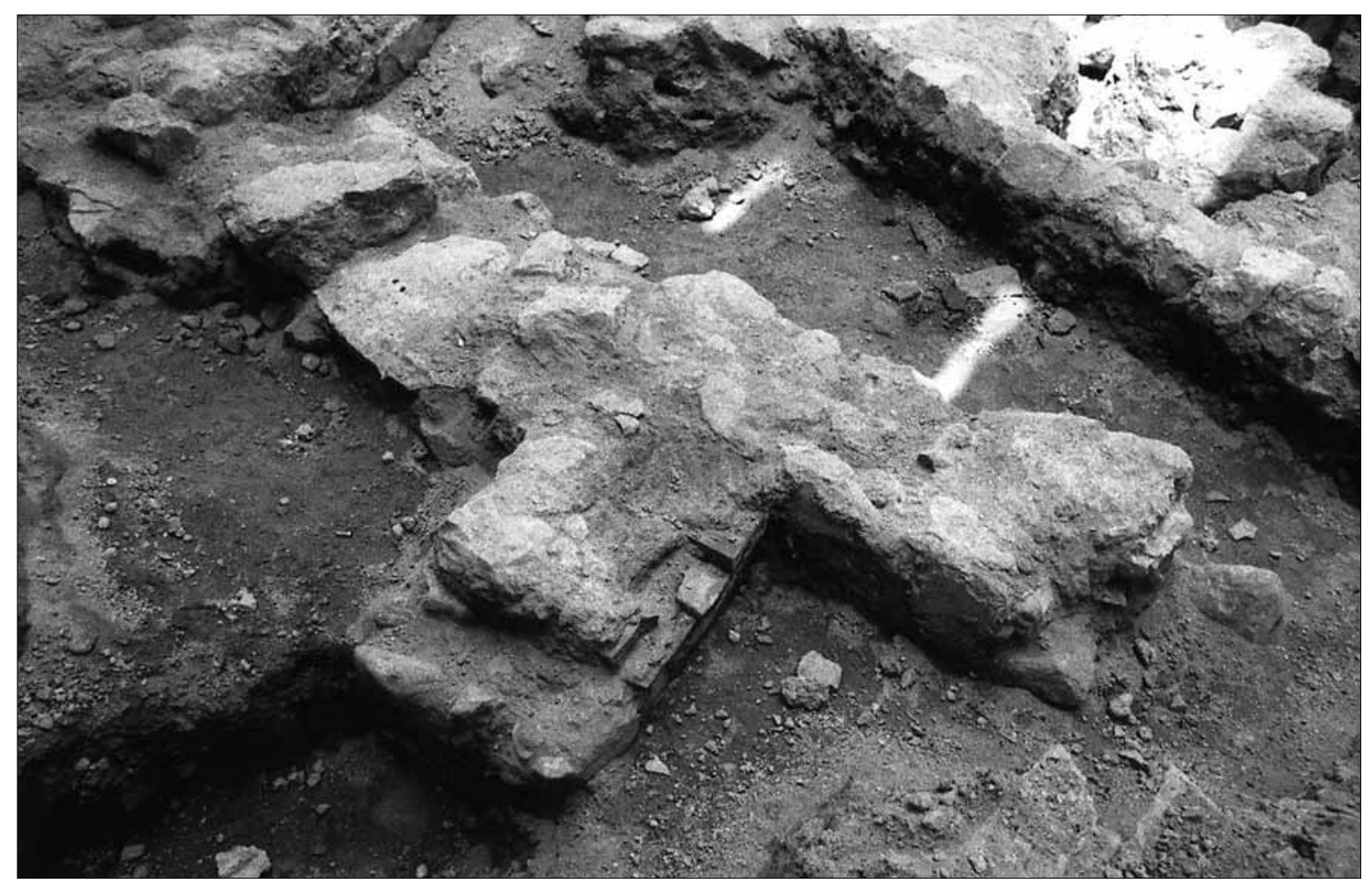




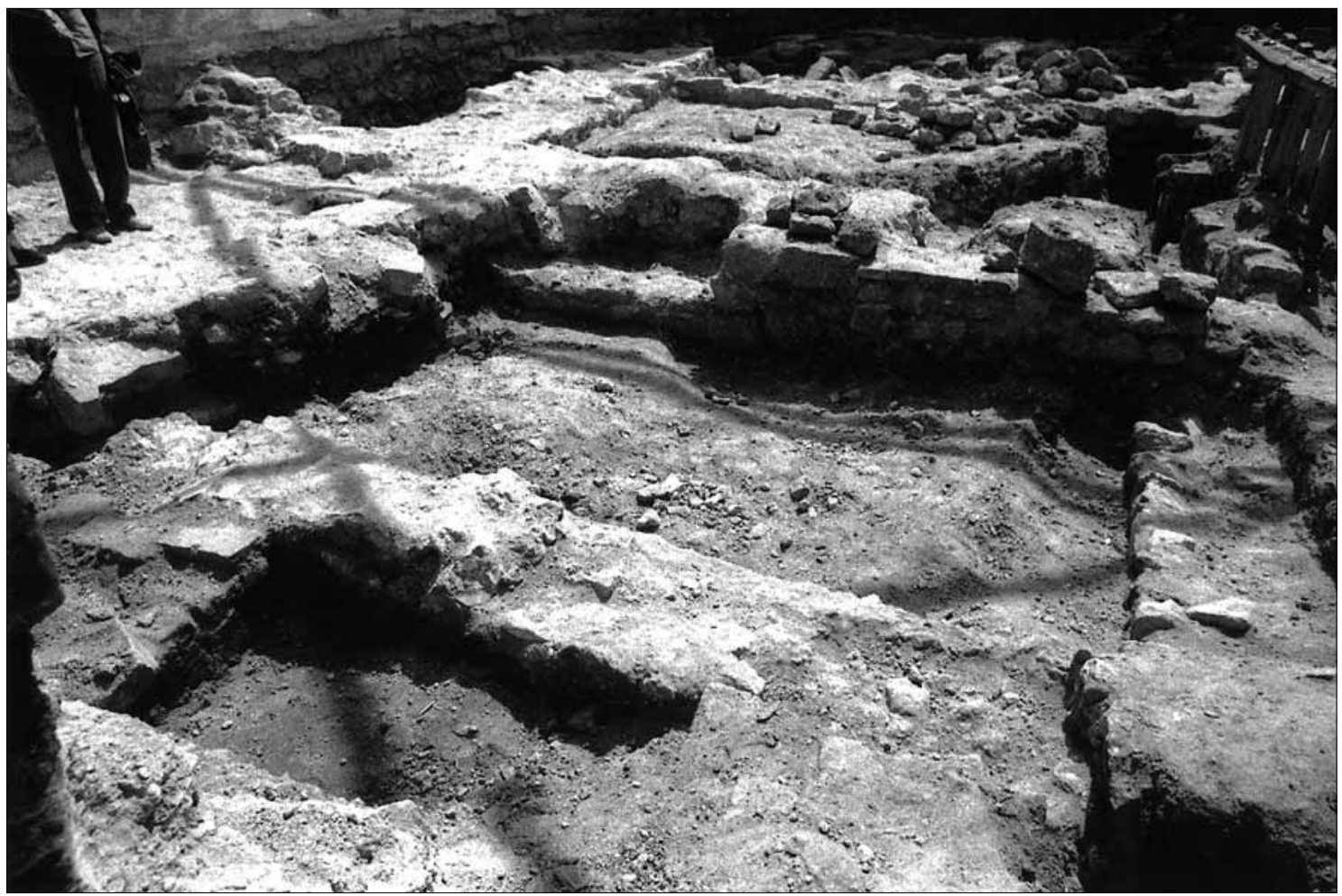

Lám. 77. Detalle de los muros hallados en la excavación. 1981

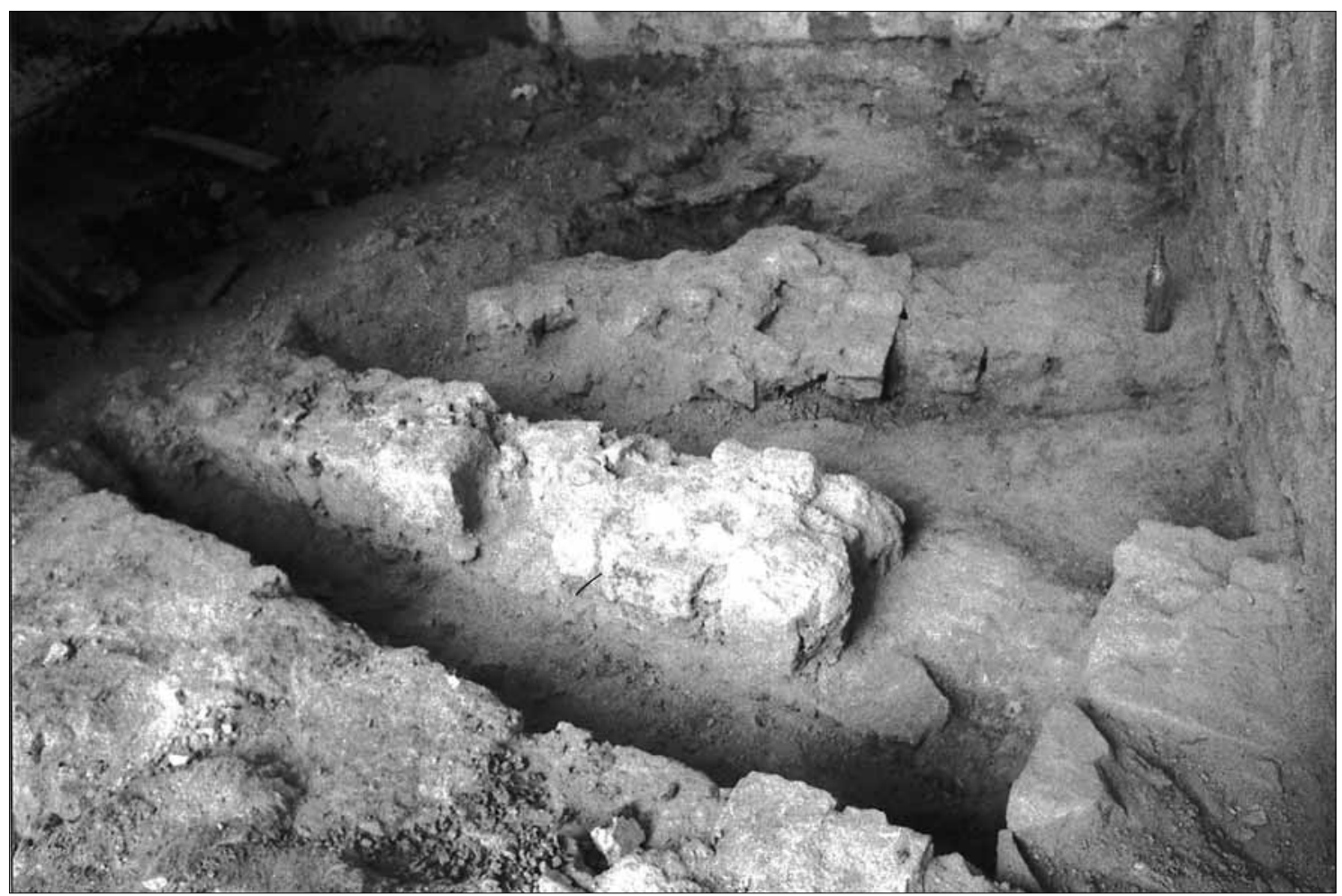

Lám. 78. Detalle de los muros hallados en la excavación. 1981 


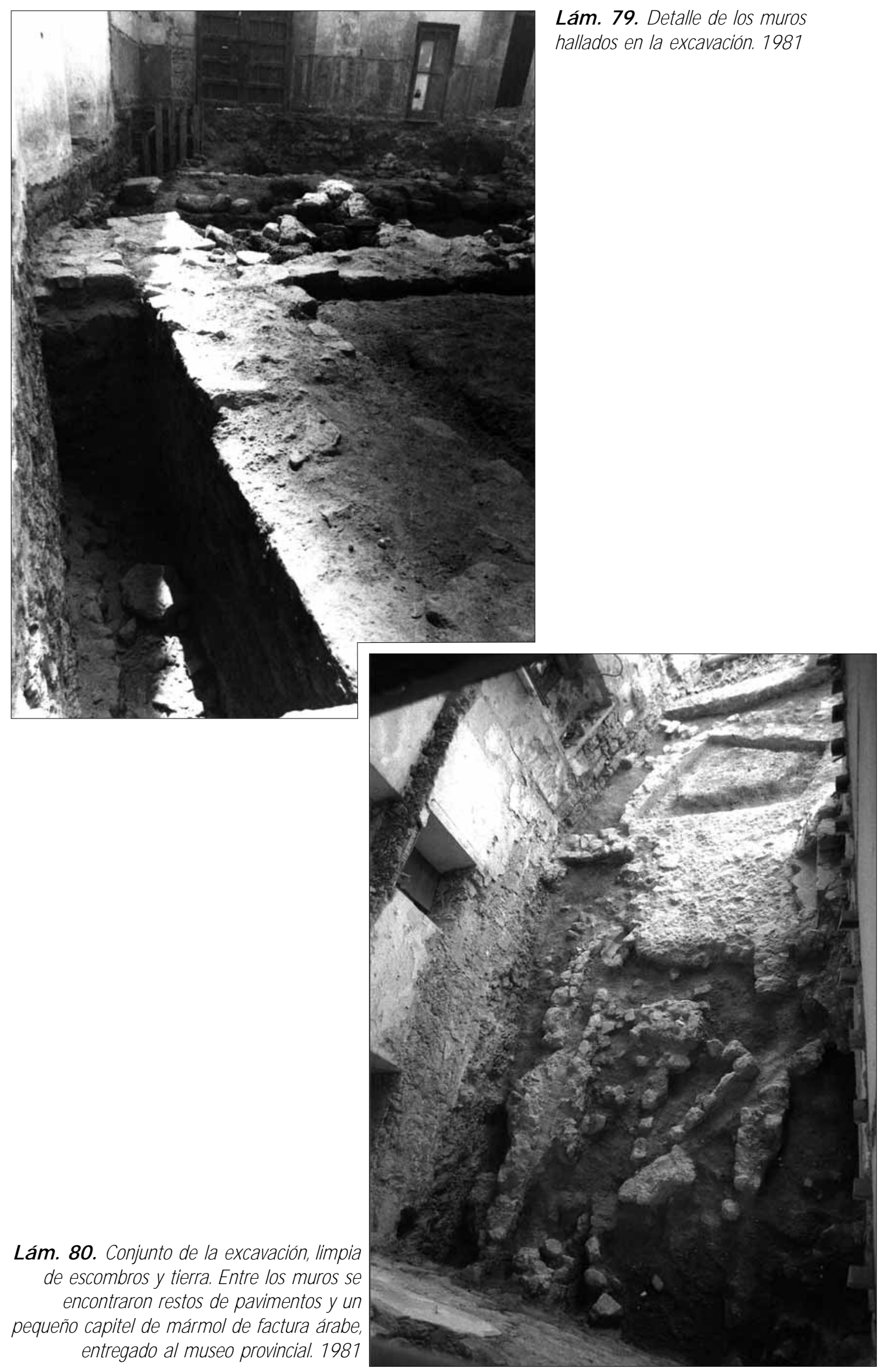




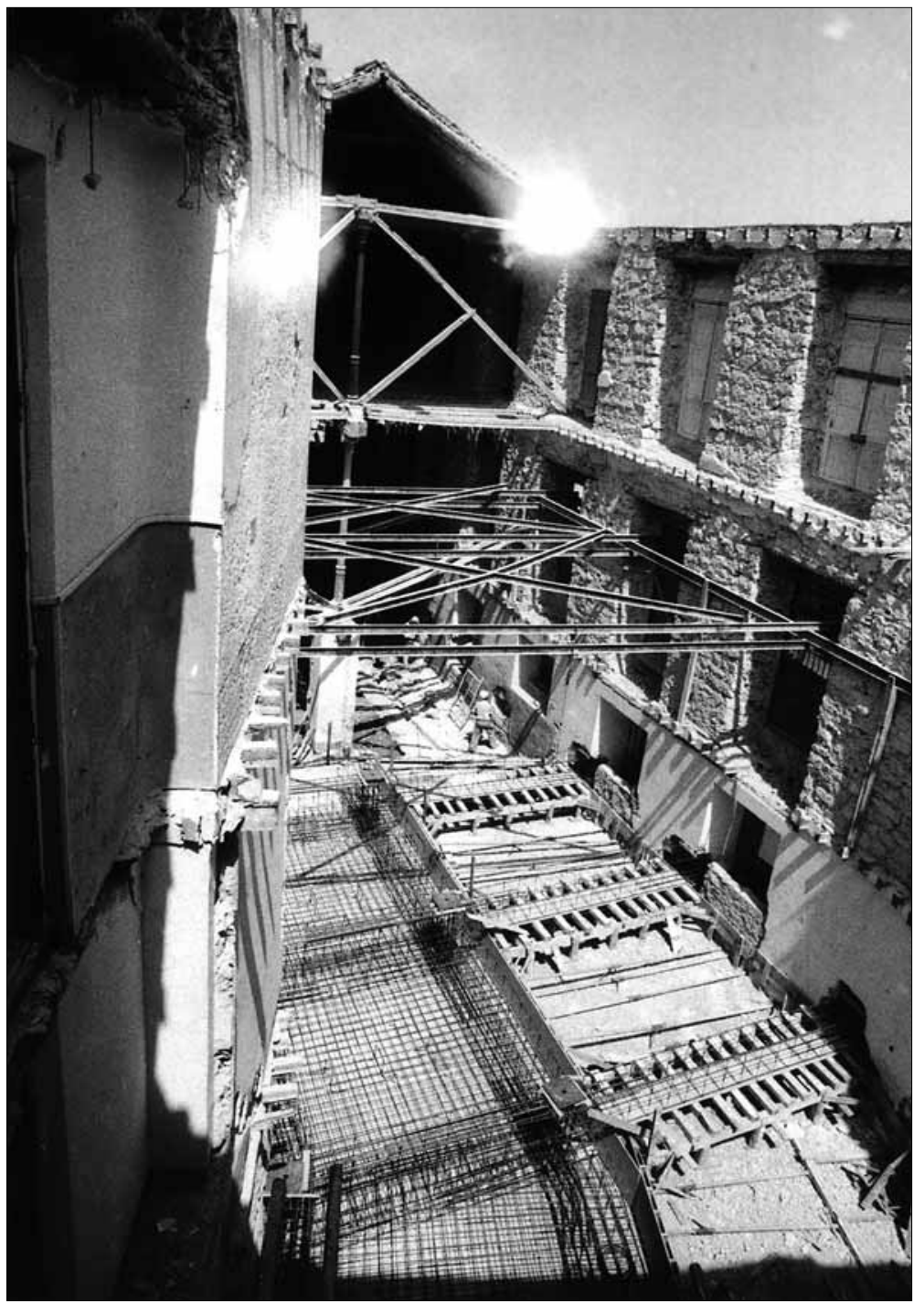

Lám. 81. Forjado de piso de la planta baja sobre los restos de muros hallados. Se efectuó un relleno de gravilla para obtener un enrase general y entre el conjunto y el forjado se dejó una cámara de aire. 1981

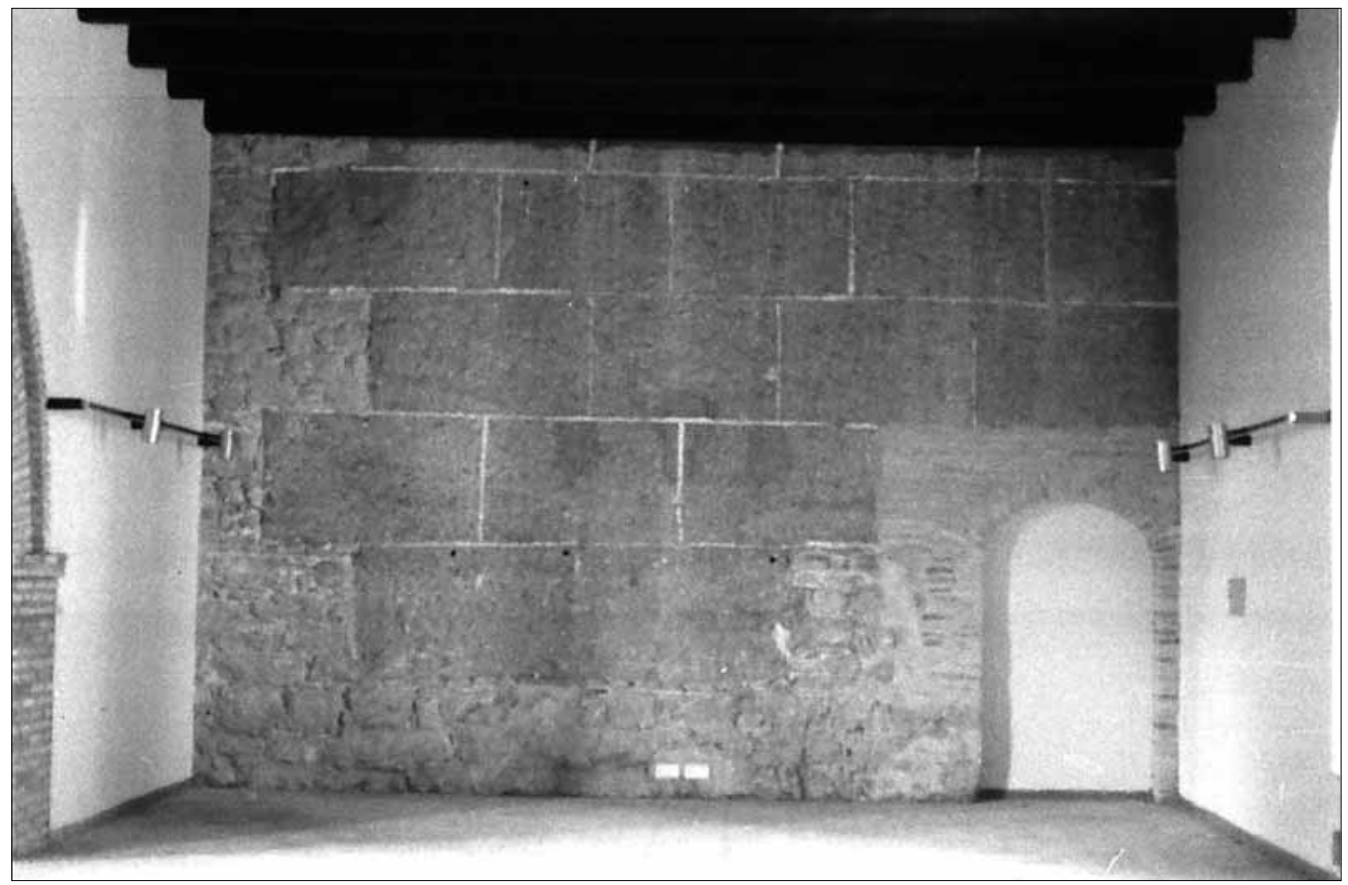

Lám. 82. Muro de tapial de la edificación del siglo XVI, ejemplo de perfección de ejecución. 1981 


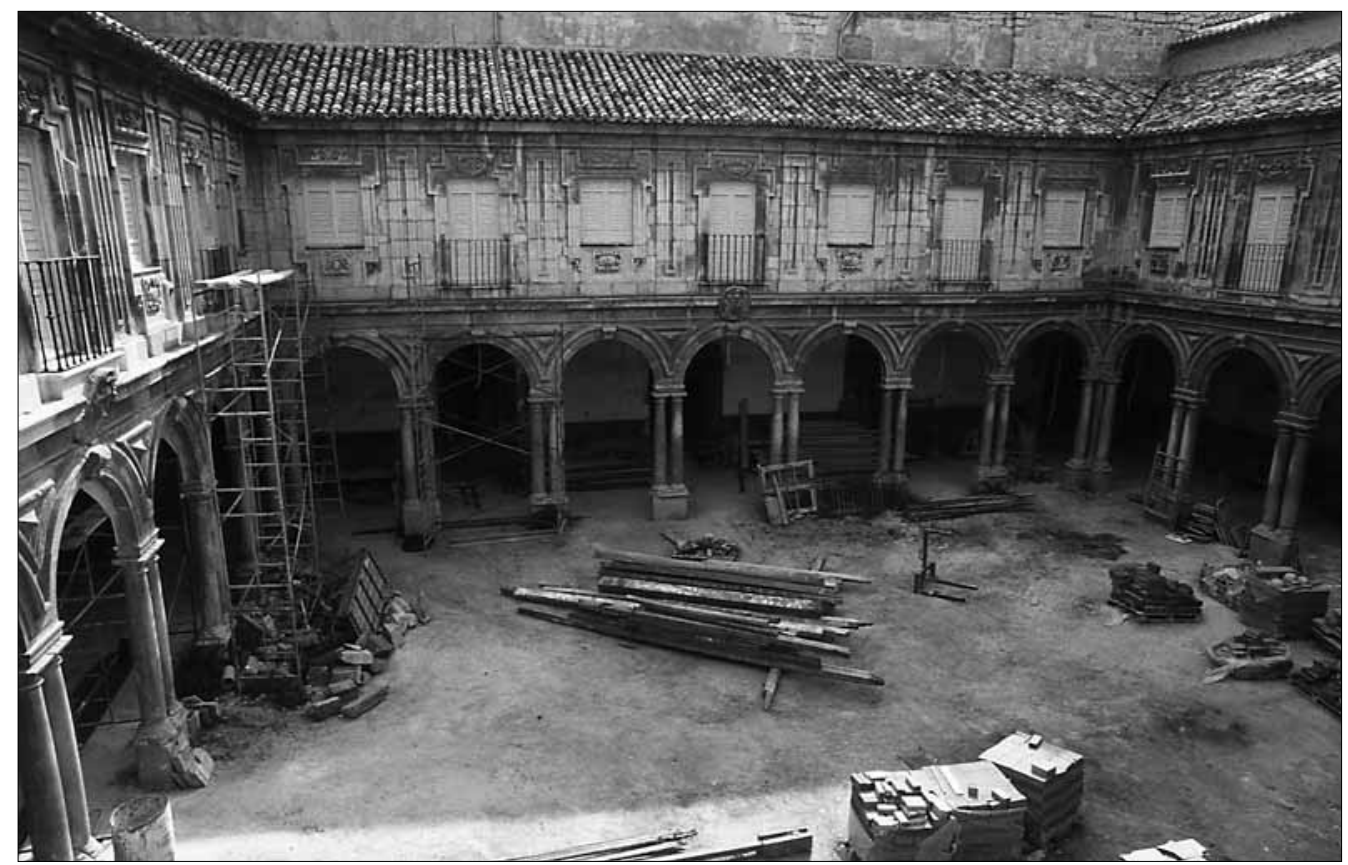

Lám. 83. Obras de restauración en la sillería del claustro, de daños cansados por erosión del agua de lluvias y heladas. 1979

Lám. 84. Obras de restauración en la sillería del claustro, de daños cansados por erosión del agua de lluvias y heladas. 1979

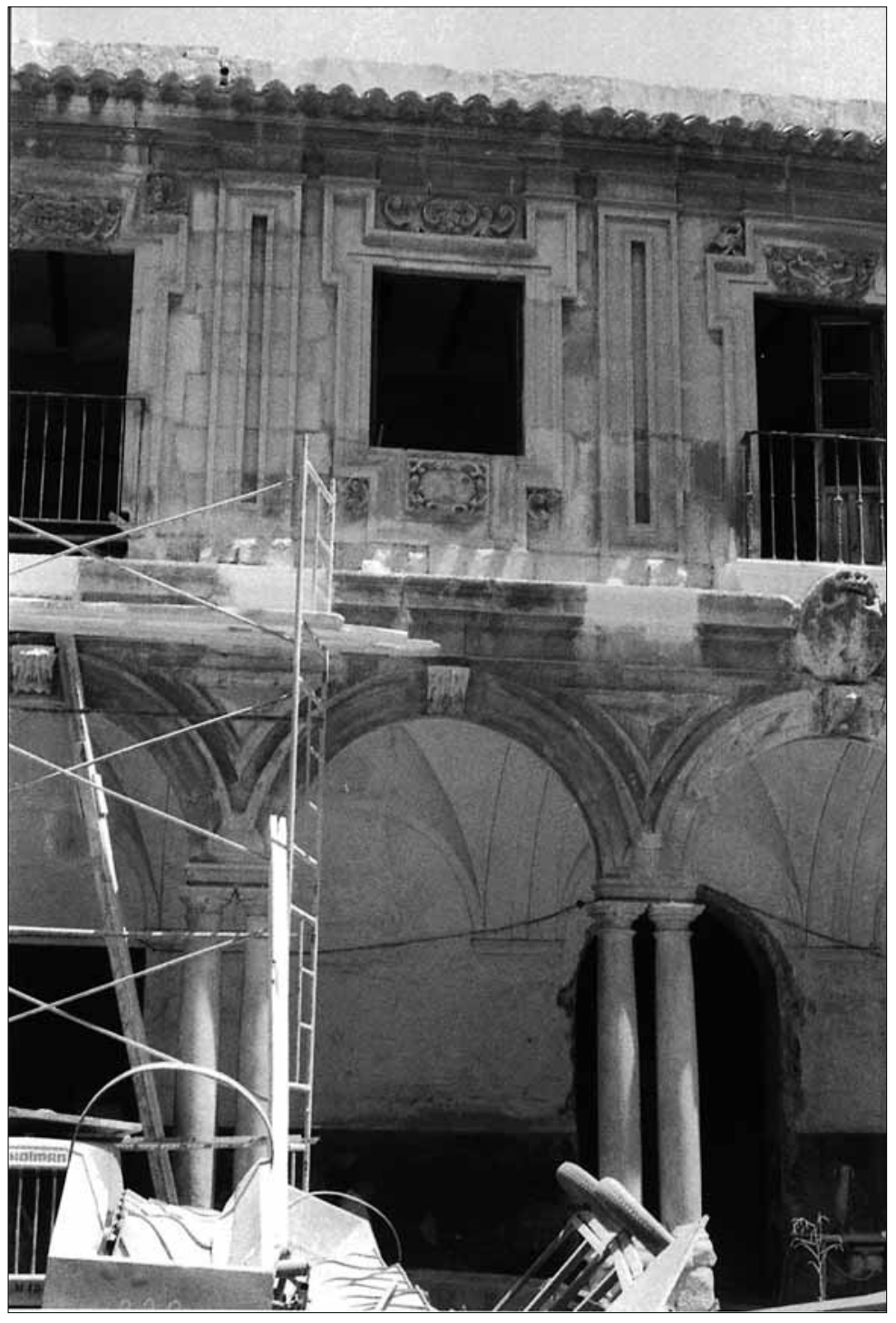




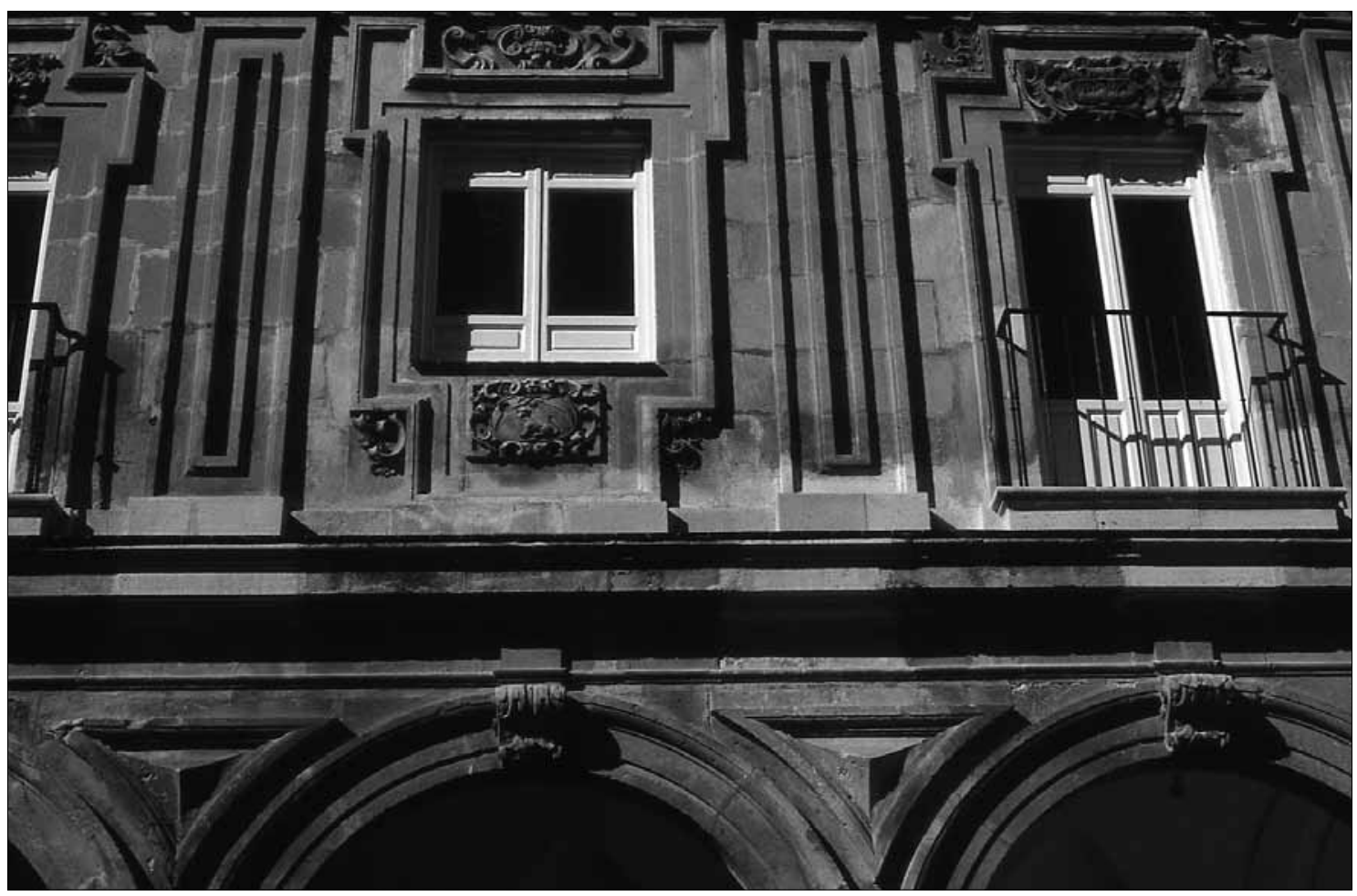

Lám. 85. Detalles de las partes restauradas, donde la talla incluso había desaparecido. 1979

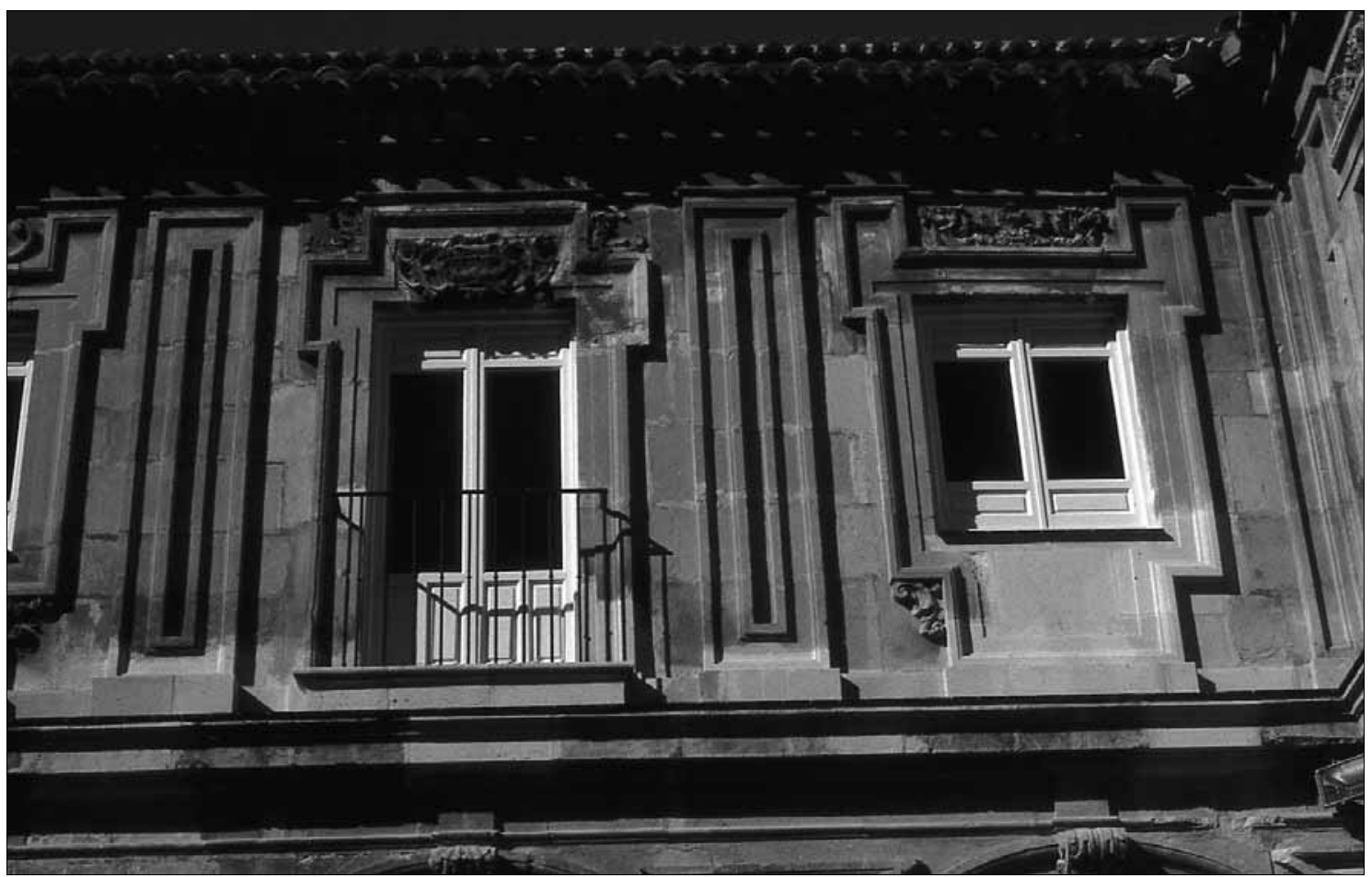

Lám. 86. Detalles de las partes restauradas, donde la talla incluso había desaparecido. 1979 


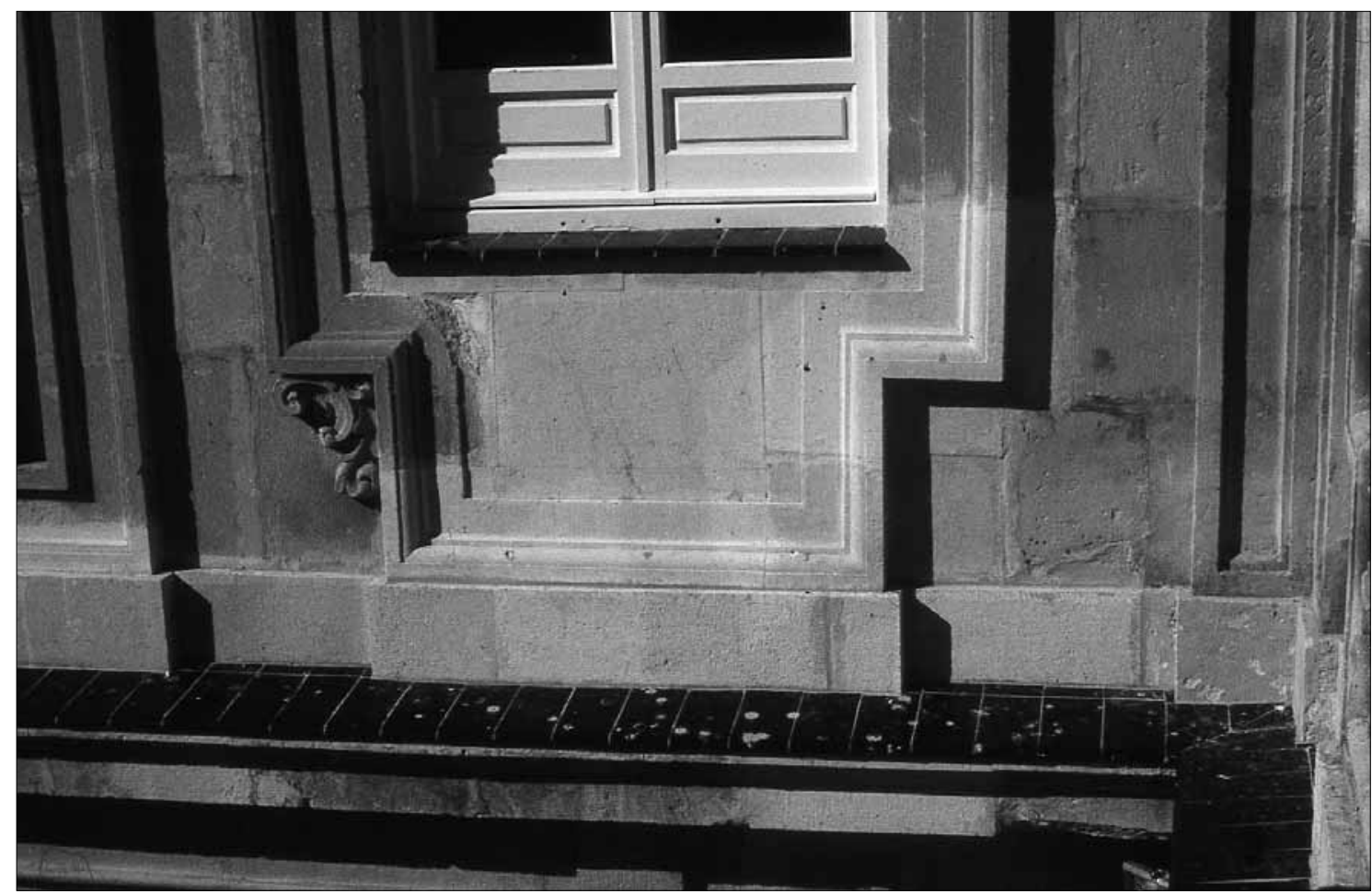

Lám. 87. Detalles de las partes restauradas, donde la talla incluso había desaparecido. 1979

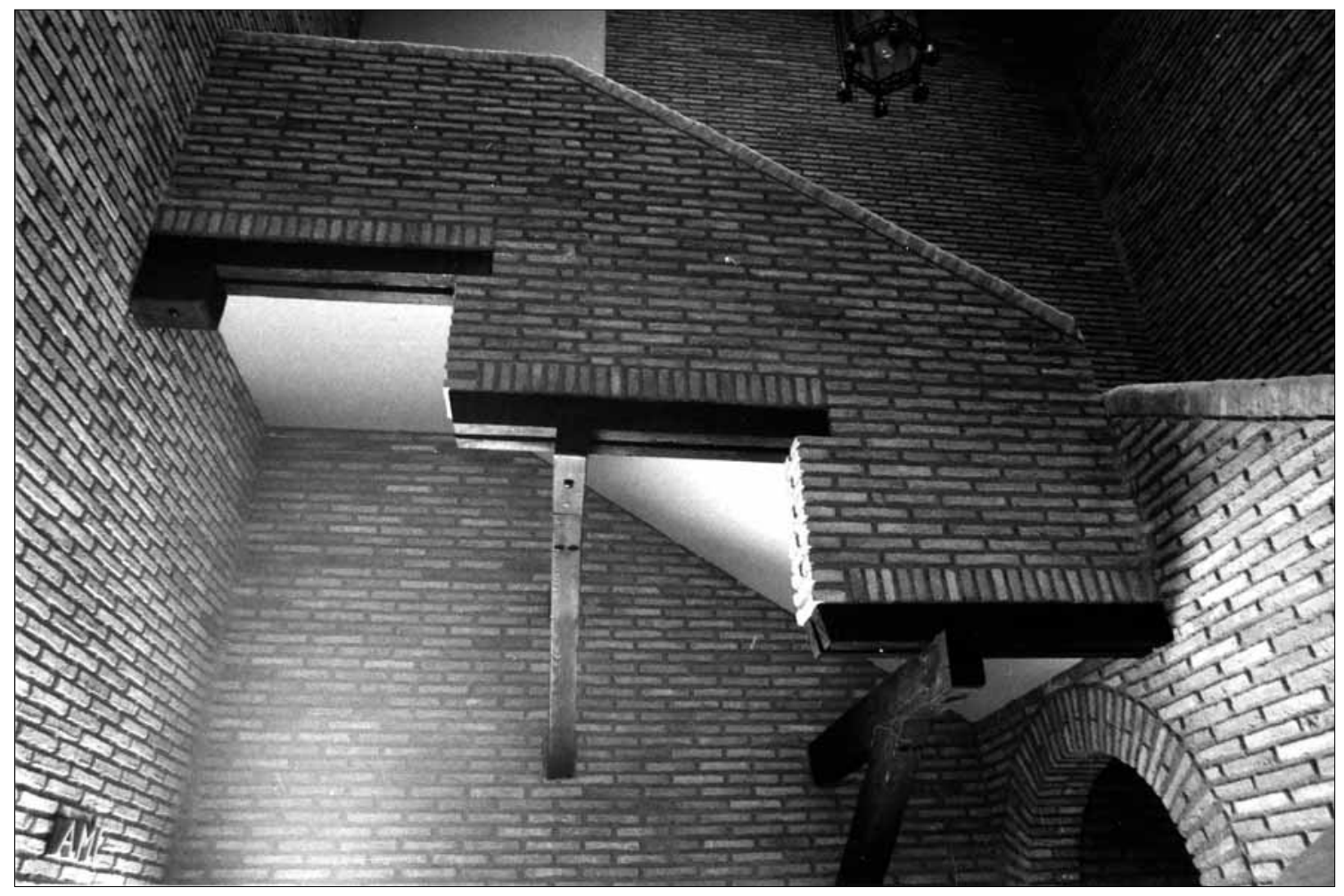

Lám. 88. Detalle de la nueva escalera principal. 1981 


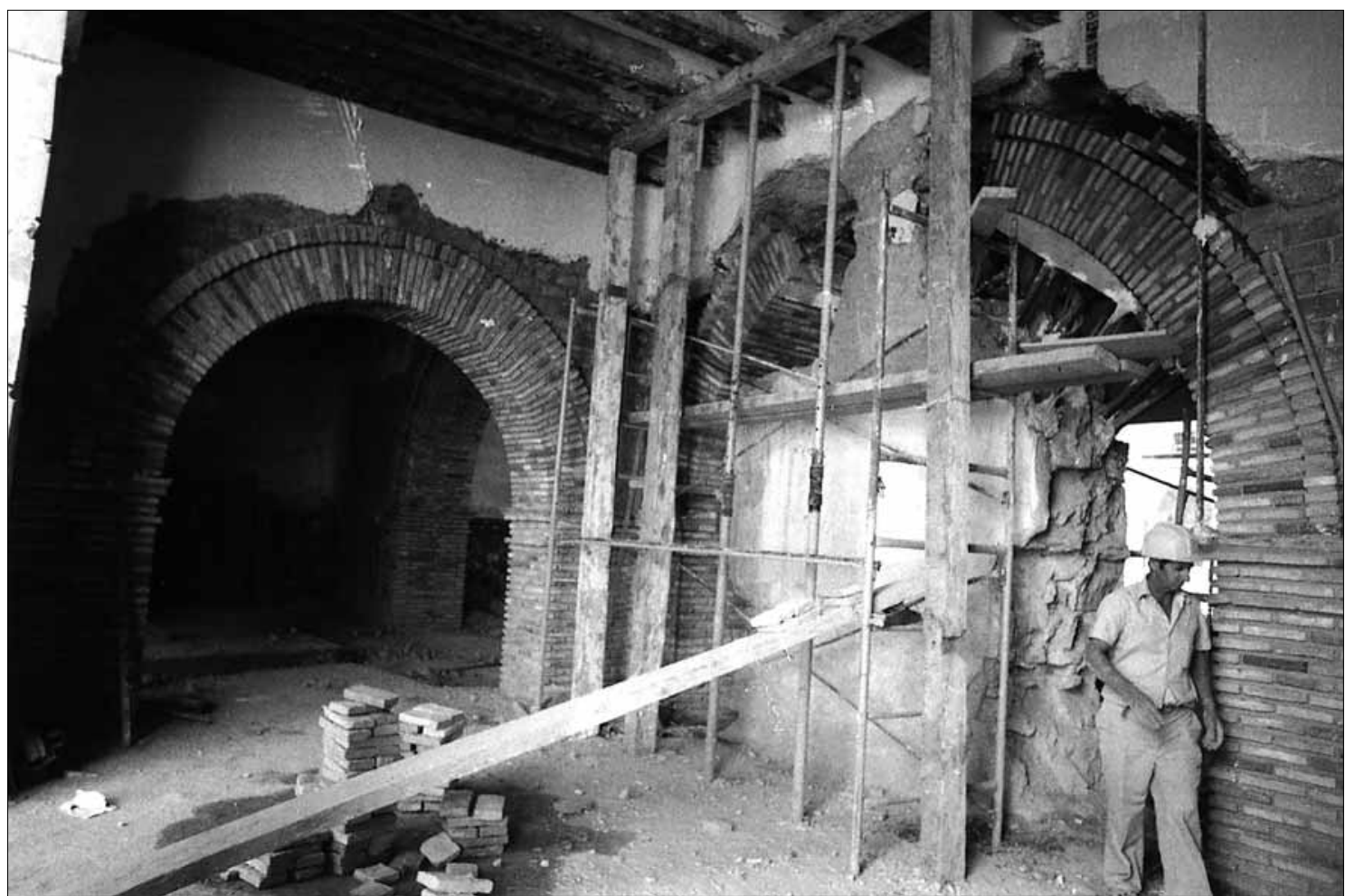

Lám. 89. Construcción de arcos de ladrillo en los muros de tapial que dividían el espacio destinado a salón de conferencias. 1981

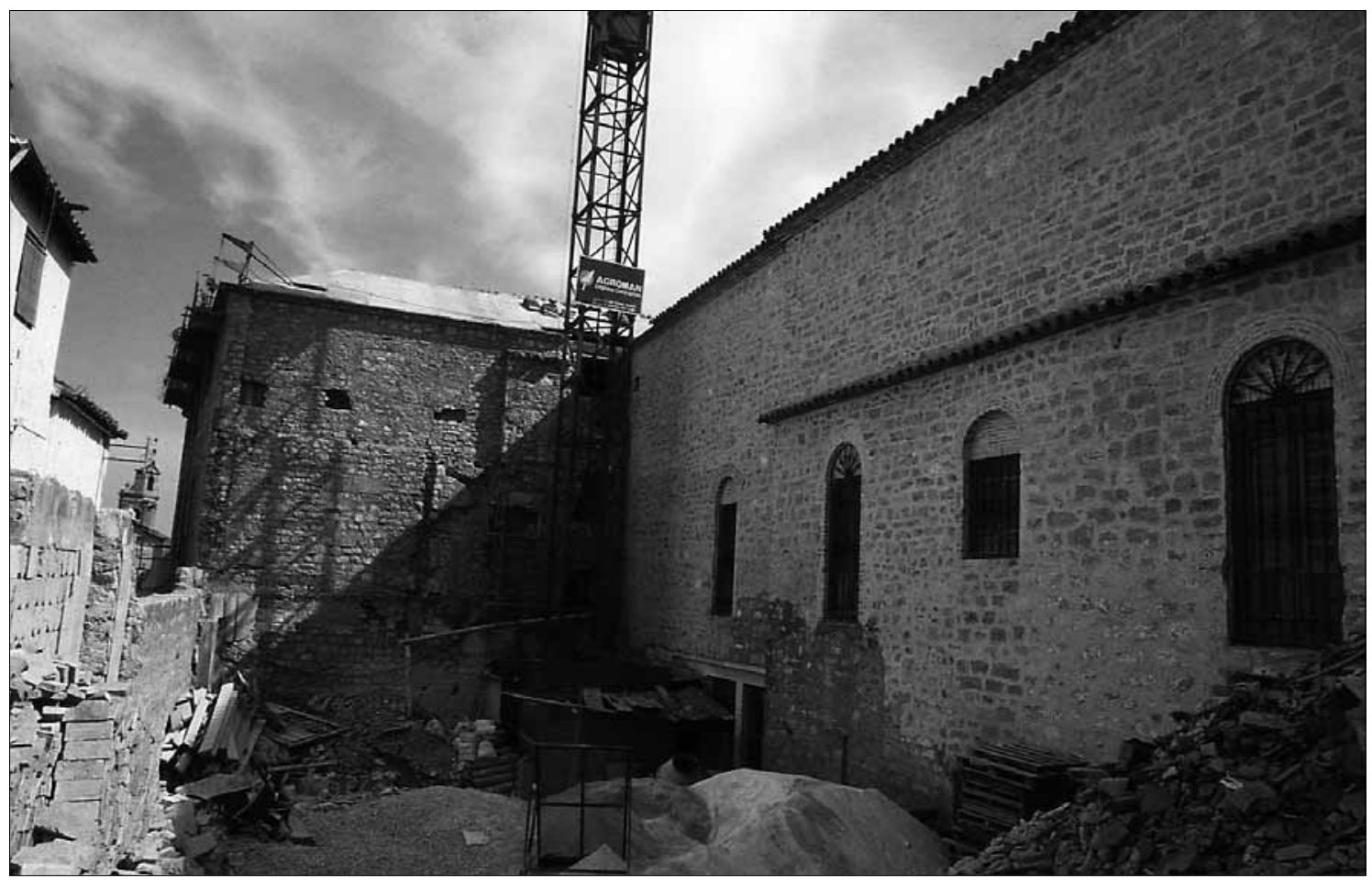

Lám. 90. Trabajos en el patio de Atarazanas. 1981 


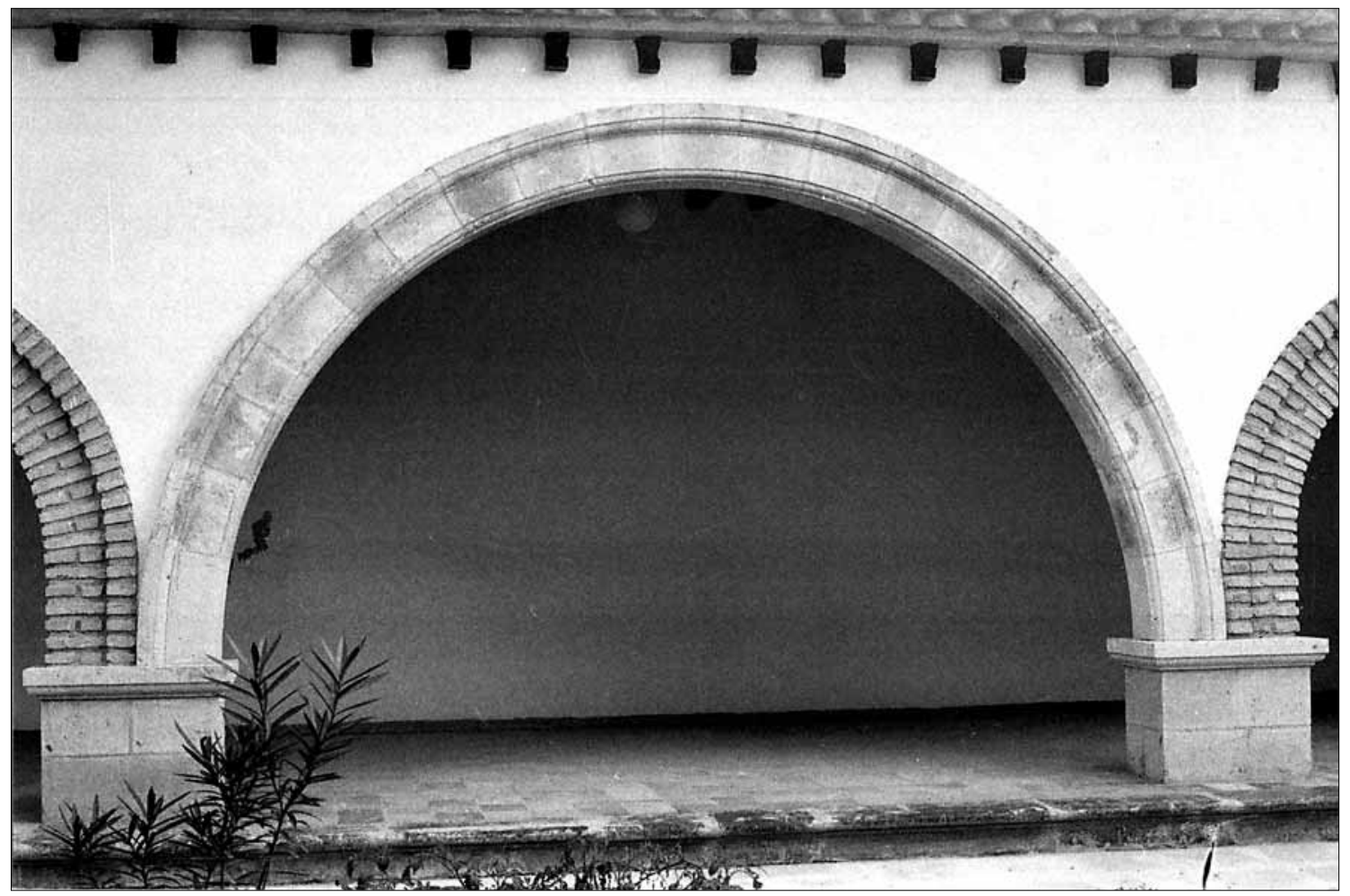

Lám. 91. Galería de tránsito en el llamado patio primero. Las dovelas del arco central pertenecieron al hospital de mujeres recogidas. 1981

Lám. 92. Viguería portante para el forjado de piso de uno de los depósitos de legajos. 1981

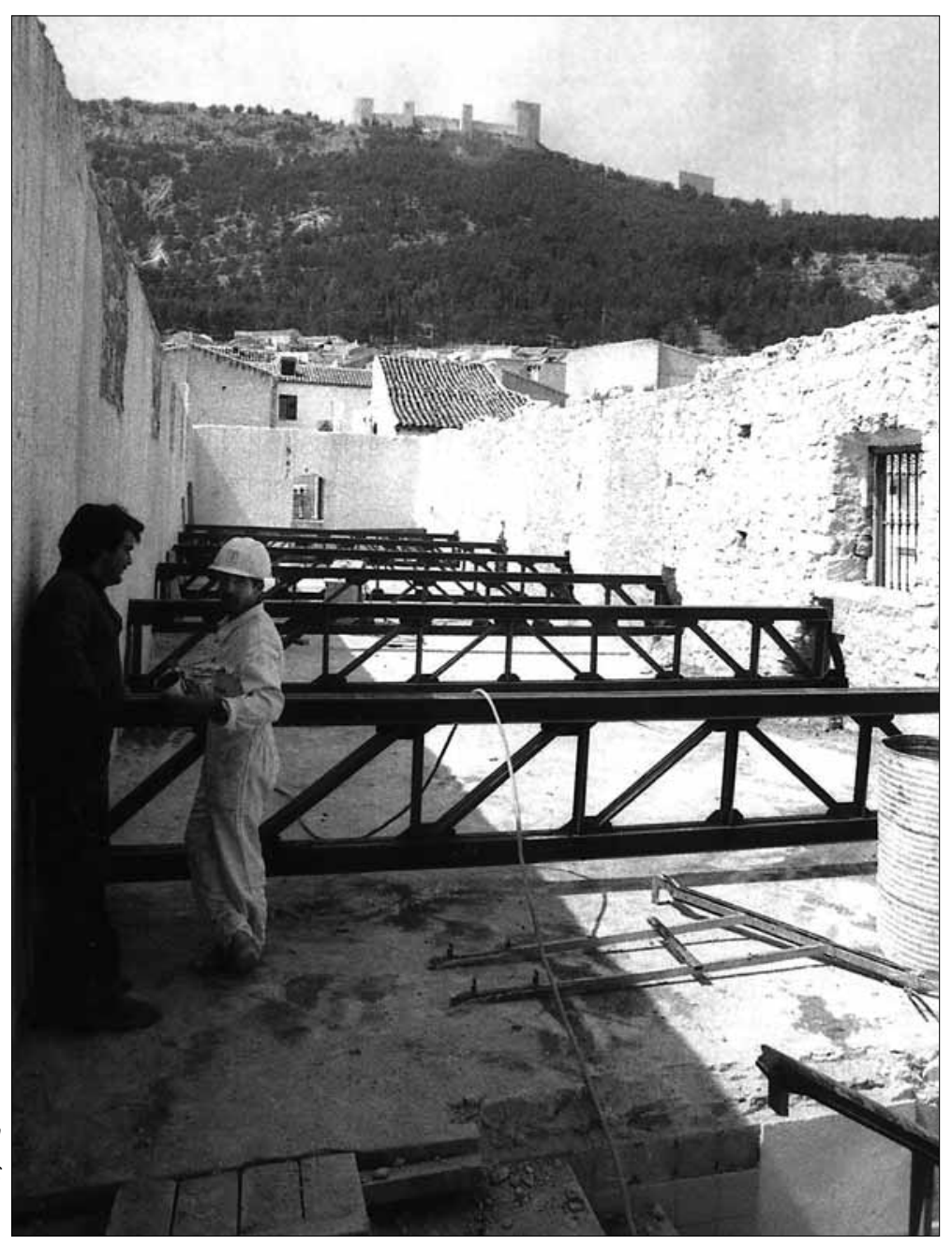




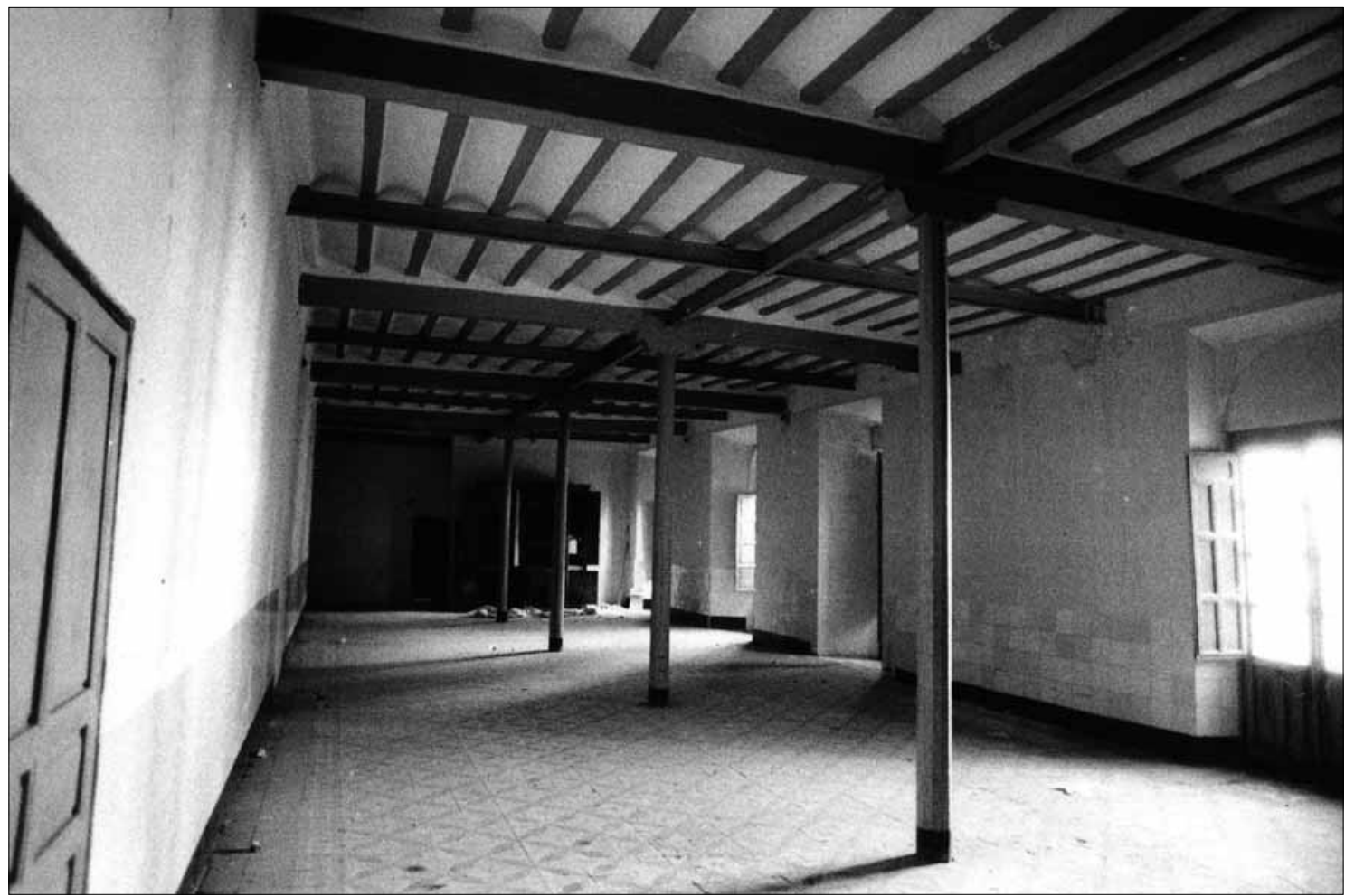

Lám. 93. Pilares de madera de la estructura de las galerías, dejados fuera de trabajo como testimonio del sistema constructivo primitivo. 1981 